\title{
Talking in and out of place
}

Citation for published version (APA):

Thissen, L. C. S. (2018). Talking in and out of place: ethnographic reflections on language, place, and (un)belonging in Limburg, the Netherlands. [Doctoral Thesis, Maastricht University]. Maastricht University. https://doi.org/10.26481/dis.20180111lt

Document status and date:

Published: 01/01/2018

DOI:

10.26481/dis.20180111lt

Document Version:

Publisher's PDF, also known as Version of record

\section{Please check the document version of this publication:}

- A submitted manuscript is the version of the article upon submission and before peer-review. There can be important differences between the submitted version and the official published version of record.

People interested in the research are advised to contact the author for the final version of the publication, or visit the DOI to the publisher's website.

- The final author version and the galley proof are versions of the publication after peer review.

- The final published version features the final layout of the paper including the volume, issue and page numbers.

Link to publication

\footnotetext{
General rights rights.

- You may freely distribute the URL identifying the publication in the public portal. please follow below link for the End User Agreement:

www.umlib.nl/taverne-license

Take down policy

If you believe that this document breaches copyright please contact us at:

repository@maastrichtuniversity.nl

providing details and we will investigate your claim.
}

Copyright and moral rights for the publications made accessible in the public portal are retained by the authors and/or other copyright owners and it is a condition of accessing publications that users recognise and abide by the legal requirements associated with these

- Users may download and print one copy of any publication from the public portal for the purpose of private study or research.

- You may not further distribute the material or use it for any profit-making activity or commercial gain

If the publication is distributed under the terms of Article $25 \mathrm{fa}$ of the Dutch Copyright Act, indicated by the "Taverne" license above, 


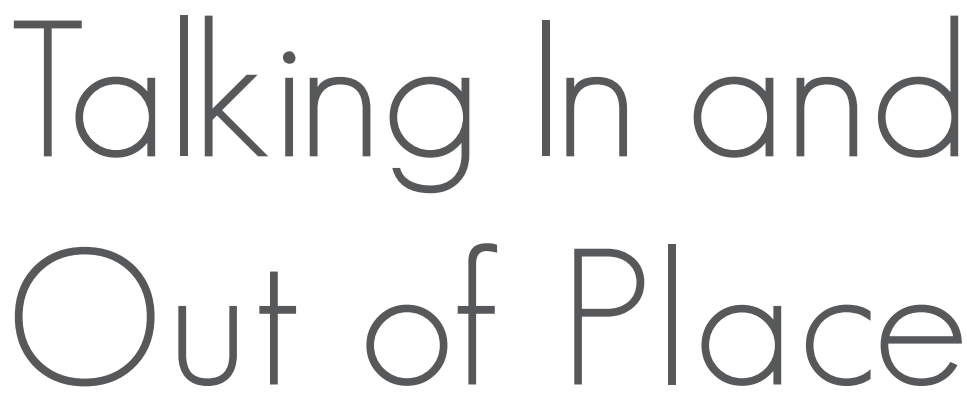

Ethnographic reflections on language, place, and (un)belonging in Limburg, the Netherlands 
Cover design and layout: Tedje Pohlen - Boolieq Print: Printservice Ede

ISBN 978-94-92679-27-7 


\section{TALKING IN AND OUT OF PLACE}

Ethnographic reflections on language, place, and (un)belonging in Limburg, the Netherlands

\section{PROEFSCHRIFT}

ter verkrijging van de graad van doctor aan de Universiteit Maastricht, op gezag van de Rector Magnificus, Prof. dr. Rianne M. Letschert volgens het besluit van het College van Decanen, in het openbaar te verdedigen op donderdag 11 januari 2018 om 16.00 uur.

door

Lotte Christoffel Suzanne Thissen 


\section{Promotor}

Prof. dr. L. Cornips (Meertens Instituut/KNAW en Maastricht University)

\section{Copromotores}

Dr. V. de Rooij (Universiteit van Amsterdam)

Prof. dr. I. Stengs (Meertens Instituut/KNAW and VU Amsterdam)

\section{Beoordelingscommissie}

Prof. dr. M. Buitelaar (Rijksuniversiteit Groningen)

Prof. dr. A. Knotter (voorzitter)

Prof. dr. W. Kusters

Prof. dr. V. Mazzucato

Prof. dr. J. Swanenberg (Tilburg University)

Dit proefschrift is gefinancierd door Provincie Limburg en de faculteit voor Cultuur- en Maatschappijwetenschappen van Maastricht University. 


\section{Table of Contents}

Acknowledgments - Dankwoord 8

Transcription Conventions $\quad 12$

List of Figures 13

1 Introduction 15

1.1 The fieldwork location: Roermond 17

1.2 Limburg: A piece of foreign country in the Netherlands 21

1.3 Center-periphery dynamics 22

1.4 Accents and dialects in Limburg 23

1.5 Place-making processes 24

$\begin{array}{lll}1.6 & \text { Politics of (un)belonging } & 26\end{array}$

$\begin{array}{lll}1.7 & \text { Language as resource in spatial repertoires } & 29\end{array}$

$\begin{array}{lll}1.8 & \text { Linguistic diversity in Roermond } & 31\end{array}$

1.9 Research cases and outline of the book 33

$2 \quad$ Ethnographic methodology $\quad 37$

$\begin{array}{ll}\text { Introduction } & 37\end{array}$

$\begin{array}{lll}2.1 & \text { The importance of grounded ethnography } & 41\end{array}$

2.2 Ethnographic techniques and reflexivity 45

2.3 The selection, orthographic transcription, and analysis of empirical data 51

$2.4 \quad$ Ethical considerations $\quad 52$

Conclusion 53

Part I: Carnival celebration practices at De Katers in the former 55 village of Maasniel

$3 \quad$ Entering the field of carnival celebration at De Katers 56 carnival association from Maasniel

Introduction $\quad 56$

3.1 Carnival celebration practices in Limburg and at De Katers carnival association 57

3.2 Doing ethnographic fieldwork at the carnival association of De Katers 69

$\begin{array}{lll}3.3 & \text { Fieldwork ethics and practicalities } & 72\end{array}$

$\begin{array}{ll}\text { Conclusion } & 74\end{array}$

$4 \quad$ Neel remains Neel: Carnivalesque place-making practices $\quad 76$ at De Katers carnival association from Maasniel

Introduction $\quad 76$

4.1 Carnivalesque place-making practices within center-periphery dynamics 80

4.2 Linguistic place-making practices: assembling spatial repertoires 91

Conclusion 98 
$5 \quad$ "And then we really switch to plat": Place-making and politics

of (un)belonging through language choice in a carnival event at De Katers

$\begin{array}{ll}\text { Introduction } & 101\end{array}$

5.1 Sinterklaas and the carnival event at De Katers 103

5.2 Language ideology in practice during the prince announcement 109

5.3 Place-making processes and politics of (un)belonging through language choice 111

5.4 Local place-making processes and politics of (un)belonging 116

Conclusion 119

Part II: The everyday chitchatting practices of two men on Roermond 121 city center's Munsterplein plaza

$6 \quad$ "We are no Limburgers": Feeling in and out of place in Limburg 122

$\begin{array}{ll}\text { Introduction } & 122\end{array}$

6.1 The language practices of David and Zeegert 125

$\begin{array}{ll}6.2 & \text { Being both in and out of place } \\ 6.329\end{array}$

6.3 Recurring oppositions of (un)belonging 136

$\begin{array}{ll}\text { Conclusion } & 146\end{array}$

Part III: Grocery practices at the Dost Market supermarket in Roermond's 149

De Donderberg neighborhood

$7 \quad$ Entering the field of grocery practices at De Donderberg's Dost Market 150

$\begin{array}{ll}\text { Introduction } & 150\end{array}$

$7.1 \quad$ Doing ethnographic fieldwork at Dost Market 152

$\begin{array}{lll}7.2 & \text { The location of Dost Market } & 153\end{array}$

$\begin{array}{lll}7.3 & \text { Grocery practices at Dost Market } & 158\end{array}$

$\begin{array}{lll}7.4 & \text { Fieldwork ethics and practicalities } & 167\end{array}$

$\begin{array}{ll}\text { Conclusion } & 169\end{array}$

$8 \quad$ Where kapusta is a greeting: Negotiating foreignness and 170 place-making through languaging at Dost Market

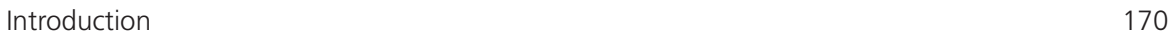

8.1 The construction of foreignness 172

$\begin{array}{lll}8.2 & \text { Spatial repertoires in use at Dost Market } & 178\end{array}$

8.3 Displaying spatial repertoires in the linguistic landscape of Dost Market 190

Conclusion 196 
9 "Because here we live in the Netherlands": Constructing foreignness and politics of (un)belonging in a situated interaction at Dost Market

$\begin{array}{ll}\text { Introduction } & 198\end{array}$

9.1 From a quarrel about small coins to politics of (un)belonging 199

9.2 Politics of (un)belonging in interaction: claiming, justifying, and challenging 204

9.3 Foreignness in practice: constructing norms of foreignness 206

9.4 The ambiguities of dialect use in the construction of foreignness 208

9.5 The ambiguities of belonging and unbelonging: what is one's 'own' country?

$\begin{array}{ll}\text { Conclusion } & 216\end{array}$

$10 \quad$ Talking in and out of place: concluding remarks $\quad 218$

$\begin{array}{ll}\text { The research cases of Part I, II, and III } & 219\end{array}$

$\begin{array}{lr}\text { Four conclusions } & 220\end{array}$

$\begin{array}{ll}\text { Academic relevance and implications } & 223\end{array}$

$\begin{array}{ll}\text { Recommendations for society } & 224\end{array}$

$\begin{array}{ll}\text { Suggestions for future research } & 226\end{array}$

$\begin{array}{lr}\text { Talking in and out of place } & 226\end{array}$

$\begin{array}{lr}\text { Appendix A } & 228\end{array}$

$\begin{array}{lr}\text { Appendix B } & 231\end{array}$

$\begin{array}{lr}\text { Appendix C } & 234\end{array}$

$\begin{array}{ll}\text { Bibliography } & 236\end{array}$

$\begin{array}{lr}\text { Nederlandse samenvatting } & 254\end{array}$

$\begin{array}{lr}\text { Valorization Addendum: Kansen voor kennisvalorisatie } & 258\end{array}$

$\begin{array}{lr}\text { About the author } & 263\end{array}$ 


\section{Acknowledgments - Dankwoord}

One of my first expressions was Otte zelf (Otte on her own) to express that I wanted to do something on my own without any assistance or help. In practice, this sometimes ended up with my mom, aunt or grandma cleaning up my mess. This also holds true for this book. Although 'Otte' was indeed the responsible fieldworker and author of this book, I could not have written this dissertation without supervisors, colleagues, research participants and many dear family members and friends who helped, assisted, and supported me and my mess over the last six (ssh..) years. In these acknowledgements, I will thank them in the linguistic forms that we mostly used throughout the passed years. I hope I did not forget to thank anyone.
Eén van mijn eerste uitdrukkingen was 'Otte zelf' om aan te geven dat ik iets zelf wilde doen zonder hulp of ondersteuning. In de praktijk kwam het er soms op neer dat mijn moeder, tante of oma mijn zootje konden opruimen. Dat geldt ook voor dit boek. Ook al was 'Otte' inderdaad de verantwoordelijke veldwerker en schrijfster van dit boek, ik had dit proefschrift niet kunnen schrijven zonder dat promotoren, collega's, deelnemers van het onderzoek en vele dierbare familieleden en vrienden mij gedurende de afgelopen zes (sst..) jaar hebben geholpen en ondersteund met mijn zootje. In dit dankwoord, zal ik hen bedanken met de talige vormen die we in de afgelopen jaren meestal gebruikten. Ik hoop dat ik niemand vergeten ben te bedanken.

First of all, I am so grateful for the support and trust of three very important persons: my supervisor Leonie and co-supervisors Vincent and Irene. Leonie, vanaf het moment dat wij elkaar zagen in het gebouw aan de Grote Gracht, wist ik dat wij een goed team zouden gaan vormen. Wat waren dit intense maar mooie jaren waarin jij het beste in mij naar boven hebt gehaald, al was dat soms o zo lastig. Ik kijk met veel plezier terug op onze samenwerking en de mooie reisjes die we hebben gemaakt: Berlijn, Edinburgh, Finland en Barcelona als hoogtepunten. Ik bedank je voor je ongelofelijke toewijding en gedrevenheid, je enthousiasme voor mijn onderzoek en je constante vertrouwen in mijn kunnen! Vooral de laatste zes maanden van het traject zijn mij heel dierbaar en het is met weemoed dat ik dit schrijf. Vincent en Irene, jullie waardevolle opmerkingen en feedback maakten dat ik hoofdstukken kritisch kon bekijken en verbeteren. Bovendien zorgden jullie voor balans in het begeleidingsteam en herinnerden jullie me aan het antropologische pad wanneer de sociolinguïstiek te zeer aan me trok. Zonder jullie als beresterk drietal was dit proefschrift er niet geweest: heel veel dank!

Obviously, I am indebted to the research participants without whom I would not have been able to write this dissertation, since they were the ones who actually provided the indispensable input for this research.

Vastelaoves Vereniging De Katers oet Neel: ein waalgemeind merci veur eure gastvrijheid en aopenheid om mich in 't sezoen van 2012-2013 op te neame es 'sjtazjeer' bie eure club! 't Waas veur mich efkes winne, dae euversjtap van vastelaovend viere in de sjtad nao vastelaovend viere in ein vereniging. Gelökkig höbbe de Katers en Ketjes mich werm onthaald in Neel en opgenaome in de festiviteiten, vergaderinge en de vele angere activiteite. Ein speciaal weurd van dank aan: Jos, Leon, Eric, 't dageliks besjtuur, de Raod van Ellef, Frank, pracht-miens Wim, Marcel en dorstlustige hooghede Prins Tim I en Jeugprins Tom I. Neel blief Neel! 
Aan de twee mannen op het bankje op het Munsterplein in Roermond: bedankt voor het redden van een tot dan toe rampzalige veldwerkdag! Als enigen die dag wilden deze mannen met me te praten en maakten zij mij deelgenoot van hun ervaringen. Bovendien hielden zij mij als één van de eersten tijdens dit onderzoek een spiegel voor. Hierdoor duwden zij mij, zonder dat zij dat overigens zelf zullen beseffen, in de richting van het reflexieve perspectief dat ik in dit proefschrift hanteer.

Aan alle medewerkers en klanten van Dost Market in Roermond: heel hartelijk dank, teşekkür ederim, spas, shokran bezaf, dank uch dat ik gedurende negen maanden werd getolereerd als medewerker met bandrecorder en notitieblok. Een speciaal woord van dank gaat naar eigenaars en broers Ihsan en Seyit, jullie hebben mij snel opgenomen en gaven me het vertrouwen te mogen werken in jullie - toen nog nieuwe - winkel. Wat heb ik veel geleerd van mijn tijd bij jullie: over mezelf, over onze mooie wijk De Donderberg en over de waarde van culturele diversiteit en meertaligheid in ons dagelijks leven! Tot gauw, want ik blijf natuurlijk zwarte olijven en dadels bij Dost Market kopen!

Furthermore, I thank everyone else who contributed to my understanding of Roermond in the broadest sense and, more importantly, who enlarged my pleasure in carrying out my fieldwork. Een speciaal woord van dank gaat uit naar vriendinnenclub De Bridge onder leiding van Mar-Li Wingens en Woonkamer De Donderberg!

When I started the Ph.D. in 2011, I was the only Ph.D. of Leonie at Maastricht University. Now, upon defending my dissertation, Team Languageculture has expanded! Aan alle kuikens van Leonie: dank jullie wel voor de steun en discussies! Veel succes met de prachtige projecten, ik kijk uit naar jullie proefschriften! Speciaal woord van dank aan Jolien en Lysbeth als belangrijke en lieve sparringpartners.

To Shosh, thank you for your in-depth corrections of my English. It was a pleasure having you in Fall 2017 and showing you Maasniel and Dost Market. Leonieke, bedankt voor het corrigeren van mijn Nederlandstalige stukken! Tedje, enorm bedankt voor het vormgeven van het boek en de fantastische omslag!

From September 2011 on, I started working at the Faculty of Arts and Social Sciences (FASOS) in the magnificent buildings at Grote Gracht. The colleagues I met inside were as magnificent and were of great support the passed years. I thank my colleagues of the Department of Literature and Art and the Arts, Media, and Culture research group. Veel dank ook aan de drie beschermengelen in tijden van administratieve rompslomp: Lilian, Anja en Ineke. Aan Dorry, de geweldenaar die het klaarspeelde dat ik mijn proefschrift af kon maken na een moeilijke tijd: dank je wel! Thanks to all the people of and behind the Graduate School. And to the members of the FASoS Ethnography group: thank you for the discussions and the out-of-the-box meetings! Of course, a dissertation cannot be written without good coffee: thanks, Bandito Espresso!

Thanks to my GG86 0.002 roommates over the years for creating a safe haven and a good and gezellig atmosphere to work in: Melissa, Anna, Ties, Christophe, Stefan, Jolien, Annelies, Andrea, Konstantinos. Joan, Ties, Marieke, Tim, and Sarah, thanks for the occasional drinks, dinners, and supportive talks! Charles, mijn wijze adviseur, dank je wel voor de fijne tijd en de samenwerking tijdens After Babel! Rafael, thank you for the many conversations and the lively e-mails after you left me all alone in this Rieu-city. Maarten, haast onmerkbaar ben je een dierbare vriend geworden. Altijd bereid binnen te wandelen, chocomel te drinken en alle Ph.D. stress even weg te relativeren; veel dank!

A great thing about doing a Ph.D. is that you are able to meet and collaborate with great colleagues outside of Maastricht at conferences (the Sociolinguistics Symposia in 
2012 and 2014), in networks (the COST New Speakers network), and during trainings (the methods clinic of the great Prof. Gerd Bauman in Amsterdam, the LOT Winter schools, and Prof. Ben Rampton's summer school at King's College London). I thank all the people I met in the past years for their valuable feedback on my work.

From February till May 2015, I had my research stay as a Ph.D. fellow within the research group Language and Place - Linguistic Variation in Urban and Rural Denmark at the University of Copenhagen. Tusind tusind tak to the colleagues of the KUA's fifth floor for all the knowledge, hygge, and for making me feel so at home in Copenhagen. Special thanks go to: Pia, for your enthusiasm, knowledge, and feedback and for throwing me a welcome breakfast and a delicious smørrebrød goodbye dinner with your lovely family; Frans, for being such an inspiring academic to look up to, for overwhelming me with your trust in my abilities, and for encouraging me to put a bit more effort in my madpakke for lunch; Signe, doing a Ph.D. is a big hurdle but it makes it so much easier when you can talk to lovely and talented fellows like you. And, of course, to my extended Danish family, the great flying circus of my 'hoompa' Malene, Jacob, Vera, Kai and Otto: mange mange mange tak for taking me into your home and hearts. I dearly miss our nights reading Mimbo og Jimbo and watching Dirty Dancing. I feel so honored and lucky to be den hollandske pige in the flying circus.

Gedurende dit lange promotietraject waren vrienden onmisbaar. Josca, Coco, Josefien en Janneke, dank jullie wel voor de broodnodige ontspanning in Utrecht of Maastricht en de gezellige telefoon-, FaceTime- en WhatsApp gesprekken. En Janneke, belofte maakt schuld: hartelijk dank voor het sturen van papers vanuit de UU voor mijn 'boekje'!

Then to a magnificent duo, my paranymphs. Anna, you quickly transformed from a roommate and fellow anthropologist to a dear colleague to a very dear friend with whom I share ups and downs. It is such a good sign that we never seem to run out of topics to talk about during our walks in Maastricht! You, Thomas, and Bastian are such wonderful persons to be around and I am grateful for having you in my life. It's a great honor to have you as my paranymph - thank you for your friendship and support!

Simon, wat vind ik het bijzonder om deze promotieperiode af te sluiten met jou als paranimf! Wie had kunnen bedenken dat de twee pubers die vijftien jaar geleden bij de groene steen op het schoolplein van het Stedelijk Lyceum stonden, nu beide dokter en doctor zouden zijn? Dank je wel voor jouw vriendschap: een vriendschap waarvan je weet dat die er altijd is, hoelang we elkaar ook niet spreken of zien, maar wanneer we elkaar zien dat het goed is en dat we verder kunnen gaan waar we gebleven waren!

Familie associeer ik met ongedwongenheid en gezelligheid met mensen waar je een speciale en onontkoombare (bloed)band mee hebt. Ooms, tantes en neven: dank voor jullie (bewuste en onbewuste) steun!

Een speciaal woord van dank wijd ik aan mijn opa Jos Thissen en oma Thérèse (Trees) Thissen-Janssen; wat zouden jullie onbeschrijflijk trots zijn geweest op dit proefschrift dat zich afspeelt in ós leef Remunj. Zonder mij daar eerder zo bewust van te zijn geweest, hebben jullie mij get sjoons, de leefde veur de sjtad meegegeven. Ik mis jullie nog elke dag en het proefschrift heeft me vaak op onverwachte wijze dichter bij jullie gebracht. Ik ben ervan overtuigd dat jullie op mij, onze familie en onze stad zullen proosten vanaf een mooie wolk met een glaasje jonge klare en sherry.

Sanne, wat ben ik blij dat we nog altijd dezelfde band hebben als vroeger! Van kleins af aan heb je me aangespoord de wereld in te trekken met of zonder rugzak en, 
onmisbaar voor dit onderzoek, je hebt me geleerd hoe je de vastelaovend moet vieren! Ik kijk uit naar de vele dansjes en biertjes die we samen met Ingrid als muppe zullen doen onder het motto 'we zijn begonnen'! En ook al lijk je vaak te denken dat je dae aaj tant bent waar ik vast niet op zit te wachten, het tegendeel is waar! Bedankt voor de gezelligheid, de gekkigheid, de wandelingen, de vele koffies en lunches en, bovenal, de steun toen we gezamenlijk een moeilijkere periode doormaakten!

Dirk, paps, toen je in september 2013 overleed, besefte ik pas wat voor constante stille kracht en steun je in mijn leven was. Ook al begreep je soms niet wat ik nou precies deed als 'antropo-loog'/'antropo-sprak-de-waarheid', ik hoop dat je, waar je ook bent, trots op me kunt zijn!

Mama, nu mag je eindelijk beretrots op de eerste rij - met kilo's tissues - zitten tijdens de verdediging! De afgelopen jaren hebben we het niet makkelijk gehad met het overlijden van Dirk en jouw plotse ziekte. Ik hoop dat mijn promotie niet alleen een stap naar een volgende fase is in mijn carrière maar ook naar een hernieuwde fase in jouw leven vol gezondheid en geluk. Ik ben je dankbaar voor jouw open opvoeding waardoor $i k$, al van jongs af aan, in aanraking ben gekomen met andere culturen, mensen en wereldbeelden. Of dat nu was door de pop met donkere huidskleur waardoor ik niet alleen omringd was door blanke poppen, de Novib kalenders die mijn antropologische fascinatie aanwakkerde, de verschillende kinderverhalen van Anansi tot de maatschappijkritische Alfred J. Kwak of de vele ontmoetingen die we hadden met vluchtelingen van over de hele wereld; door jou kijk ik met open vizier de wereld in en dat is zo onmisbaar voor een antropoloog! Door jou ben ik geworden wie ik nu ben en daar ben ik je heel dankbaar voor, lieve mama!

Tot slot: Adam, liefie, ghazel dyali. Jij was het die mij heeft overtuigd dat ik het in me had om te gaan promoveren. Je liet zelfs jouw zo geliefde Utrecht achter om mee te verhuizen naar Maastricht zolang we maar samen waren. Gedurende de afgelopen jaren heb jij, zonder enige twijfel, in mij geloofd. Ook als ik het zelf niet meer zag zitten, gaf jij me mijn vertrouwen terug. Jij was en bent er onvoorwaardelijk voor me en je weet wanneer je aan de noodrem moet trekken wanneer ik weer eens door wil stomen. Dit proefschrift heb ik voor het grootste deel te danken aan jouw steun, vertrouwen, geduld, incasseringsvermogen ("I wonder why it is, I don't argue like this with anyone but you"), heerlijke gekke humor en, bovenal, jouw grenzeloze liefde. Bij jou kan ik mooi en lelijk zijn, bij jou kan ik mezelf zijn, bij jou vind ik rust, bij jou vind ik mijn place en belonging in welke taal dan ook. Ik hou van je, kenbrik bezaf, ich haaj van dich. 


\section{Transcription Conventions}

\begin{tabular}{|c|c|}
\hline$x x x$ & transcriber could not hear what was said \\
\hline WORD & loud voice, relative to surrounding talk \\
\hline${ }^{\circ}$ word ${ }^{\circ}$ & soft voice, relative to surrounding talk \\
\hline word & stress on (part of) word \\
\hline$\overline{=\text { word }}$ & latching; no time between turns \\
\hline$=$ word $=$ & simultaneous speech \\
\hline wor/ & interruption \\
\hline wo::.:rd & prolonged vowels \\
\hline$[\mathrm{dc}] /[\mathrm{ac}]$ & decelerated (slower) or accelerated (faster) speech \\
\hline$\{$ word $(s)\}$ & words for which the $[d c] /[a c]$ applies \\
\hline (.) & pauses less than a second \\
\hline$(.1)$ & pauses in seconds \\
\hline . & closing intonation \\
\hline , & continuing intonation \\
\hline$?$ & questioning intonation \\
\hline $\begin{array}{l}\%[\text { word }] \\
\text { (word) }\end{array}$ & $\begin{array}{l}\text { additional transcriber's comment or translation } \\
\text { transcriber interpretation of recording }\end{array}$ \\
\hline [word] & immediate transcriber's comment on (part of) utterance \\
\hline [/word] & end of transcriber's comment on (part of) utterance \\
\hline$[\gamma]$ & voiced velar fricative in onset position; 'soft ' $g$ ' \\
\hline$[\mathrm{x}]$ & voiceless velar fricative in coda position; 'soft g' \\
\hline$[x]$ & uvular fricative; 'hard g' \\
\hline [s] & voiceless alveolar fricative; 's'-sound \\
\hline [Z] & voiced alveolar fricative; ' $z$ '-sound \\
\hline$\uparrow \downarrow$ & rise or fall in intonation \\
\hline
\end{tabular}




\section{List of Figures}

1.1 Map of the Netherlands with the province of Limburg highlighted

1.2 Map of Limburg with select major cities, including Roermond, highlighted

1.3 Map of Roermond in Limburg and a Google Maps screenshot of Roermond in detail

1.4 Photos of signposts at the borders of Herten (taken by Sanne Thissen), Swalmen (taken by John Kleijkers), and Maasniel

1.5 Composition of inhabitants by number and percentage for Roermond, Maastricht, Venlo, Limburg, and the Netherlands

1.6 Photo of guidepost in the city center of Roermond with information in Dutch, English, German, French, and Chinese

1.7 Photo of handwritten sign during Sjommelmert in Roermond

1.8 Google Maps screenshot of Roermond with the three fieldwork sites highlighted

2.1 Dataset of carnival celebration practices at De Katers carnival association in Maasniel

2.2 Dataset of chitchatting with two men on a city center bench in Roermond

2.3 Dataset of grocery practices at the Dost Market supermarket

3.1 Google Maps screenshot of Roermond with borders of Maasniel highlighted

3.2 Diagram of the structure and organization of De Katers carnival association

3.3 Descriptions of roles and functions of central figures and departments of De Katers carnival association

3.4 Photo of the monarch of De Katers carnival association and the prince during the inauguration of the prince

3.5 Photo of the prince of De Katers carnival association dancing on the table, surrounded by the monarch, the prince's guard, and members of the council of eleven

3.6 Photo of members of De Katers carnival association on their vessel during the parade in the city center of Roermond

4.1 Composition of inhabitants by number and percentage of Maasniel and Roermond

4.2 Map of Maasniel in 1842/1843 (Image courtesy of Dominique Clerkx of the website maasniel.nl)

4.3 Photo of a signpost at the border of Maasniel (Nee/)

4.4 Photo of tomcat statue on Betjesplein plaza in Maasniel

4.5 Photo of tomcat statue on roundabout in Maasniel

4.6 Google Maps screenshot of the former village of Maasniel with the old village center of Kern Maasniel highlighted

4.7 Map of the hall at De Katers residence café De Ster during the prince announcement event

4.8 Photo of the author standing on the vessel among male members of De Katers carnival association during the parade in the city center of Roermond (taken by Sanne Thissen)

4.9 Photo of De Katers carnival association's bulletin board in Maasniel inviting people to attend their events

4.10 Photo of De Katers carnival association's bulletin board in Maasniel wishing people happy holidays 
4.11 Photo of the car of the youth prince of De Katers carnival association during the parade in Maasniel

4.12 Photo of the decorated home of De Katers carnival association's youth prince

4.13 Photo of a billboard during the opening of carnival season at De Katers carnival association

4.14 Photo of De Katers carnival association's youth prince announcement

4.15 Scan of the cover of De Katers magazine KlassjeNeel from the 2012-2013 season

4.16 Examples of NO-NO and NO-YES mailbox stickers (Image courtesy of Bas Methorst from Stichting MailDB)

4.17 Photo of a sticker attached to a road sign in Maasniel saying "Yes: not born in Neel, Neel: nevertheless became a Kater"

5.1 Photo of the specially produced and distributed Sinterklaas flags for the city center of Roermond.

5.2 Screenshot of the Sinterklaasjournaal sketch where the men perform the carnival slogan, 'Alaaf,' to the reporter

5.3 Photo of Monarch Eric, Sinterklaas, and the Sinterklaas presents on stage during the prince announcement event of De Katers carnival association

5.4 Photo of the revealing of the prince of De Katers carnival association

5.5 Photo of the revealing of the prince of of De Katers carnival association

6.1 Google Maps screenshot of the city center of Roermond with the plaza of Munsterplein highlighted

6.2 Map of the Netherlands with The Hague, Zwolle, and Roermond highlighted

6.3 Map of the Netherlands depicting the distribution of velar and uvular fricatives (taken from Van Oostendorp 2011: 152) with The Hague, Zwolle, and Roermond highlighted.

7.1 Google Maps screenshot of Roermond's De Donderberg neighborhood with its quarters highlighted

7.2 Composition of inhabitants by number and percentage for De Donderberg and Roermond

7.3 Google Maps screenshot of the city of Roermond with De Donderberg neighborhood and the location of the shopping mall highlighted

7.4 Floor plan of De Donderberg neighborhood shopping mall before the renovation (Image courtesy of Traanberg Partners Architectuur en Bouwmanagement)

7.5 Diagram of Dost Market before the renovation of Roermond's De Donderberg neighborhood shopping mall

7.6 Scans of Dost Market's advertising flyer as published in December 2012

7.7 Scan of drawing of the ethnic compartmentalization of Dost Market's assortment according to the co-owner (made by the co-owner)

8.1 Continuum of multilingual practices (Wille et al. 2015: 10)

8.2 Essafir tea at Dost Market

8.3 Sałatka z zielonych pomidorów at Dost Market

8.4 Poster at the exit of Dost Market

8.5 Explanation of Arabic on the door sign at Dost Market 


\section{Chapter 1 \\ Introduction}

\section{September 2006}

I just moved from my hometown of Roermond, a city within the province of Limburg in the southeast of the Netherlands, to Utrecht, a city in the heart of the country. On my first night out as a Cultural Anthropology student, a man in a pub questions my accent: "You must be from the South, isn't that right?" This is the first of many remarks about my accent. Yet when I return with a bag full of laundry to my parents every weekend, my mother complains that my accent is becoming more Hollandic by the week - a label people in Limburg use to refer to the Dutch variant spoken outside the province.

\section{March 2009}

During my first fieldwork experience in Antigua, Guatemala, I have an interview in a nearby village. When returning home, the bus does not make a proper stop at the bus stop. Like locals, I jump onto the camioneta (public transport bus). Upon slamming my hip into the door, I swear loudly in dialect: "Nondeju! Det duit pien!" ("Holy shit! That hurts!"). The driver is startled by my utterance, which is obviously not Spanish: "Perdoname (I'm sorry), I didn't regard you as a gringa (American)!" When I look at myself in the rear-view mirror, my dark hair and skin indeed fit in nicely with the Guatemalan passengers in the bus.

\section{March 2010}

Throughout my second fieldwork experience in the former fishing village of Volendam, in the north of the Netherlands, people look at me during bike rides. They seem to wonder: Van wie bin jij 'r ien? (To whom do you relate?) When the question is asked explicitly, my response of "I come from Roermond" does not suffice. "Yes, but where do you really come from, because in Roermond benne ze niet zo donker als jij" ("they aren't as dark as you are").

July 2012

Finally, I get to return to my home province of Limburg and hometown of Roermond for my Ph.D. research! Among the very first people I talk to are two older men sitting on a bench. Upon introducing my research in Limburg, the men immediately claim: "Wij zijn geen Limburgers" ("We are no Limburgers.") They assume that I know what they mean, since a girl with such dark hair and eyes could obviously not come from Limburg herself.

\section{November 2012}

It is November 11 and my fieldwork at the carnival association starts. Why do these dialect-speaking members keep responding to me in Dutch, when I have been familiar with dialect from birth and became an active dialect speaker at a later age? 


\section{December 2012}

The fieldwork in a small-scale supermarket makes it clear that it is not just so-called 'natives' who perceive me as being out of place within the Netherlands or Limburg. People with more diverse backgrounds than 'only' Dutch think of me in a similar fashion. Customers' questions are, at first, posed in Turkish or Arabic. A conversation with the butcher stands out. When asking me whether I am a foreigner, too, I answer that I am 'half.' He responds: "Half does not exist anymore, then you are a foreigner."

\section{February 2013}

I get into a taxicab after a day of celebration with a carnival association, which by chance ended in having a few beers with my aunts. The cab driver's question brings me back to reality: "Where are you from, Morocco?" Just minutes ago I was loudly singing along with carnival songs in dialect and feeling like a Remunjs maedje (Roermond girl) through and through. How quickly the tables have turned!

Looking back at the past eleven years, I realize that notions like language practices, place-making, and belonging have been recurrent themes in my own life: language returns in the differences between dialects and Dutch in Limburg on the one hand and Dutch as it is spoken in Utrecht on the other; place-making seems to be as important in Guatemala and Volendam as in a carnival association in Limburg; lastly, questions of whether I belong - or am in or out of place in the various locations - are central in all phases of my life. This undoubtedly explains my fascination with these topics in my research and with respect to this dissertation in particular. Although realizing I was perceived as an outsider in places that were dear to me was at times a bitter pill to swallow, as an anthropologist, I learned that my 'ambivalent' background was a blessing for fieldwork: where I would regard my background as Roermondian, Limburgian and Dutch, others initially perceive me as an outsider to these 'groups' due to my darker hair, eyes, and skin color. This ambivalence enabled me to gather data that others might not have had access to.

My dissertation aims at scrutinizing these fixed connections between particular appearances and ways of speaking and acting by looking at people's actual practices in the everyday places they inhabit. In order to do this, I will take the reader to the city of Roermond in the Dutch province of Limburg, where I did ethnographic fieldwork within three different locations for over a year. My research centered on the question:

How do people, by engaging in language practices with other people, give meaning to the everyday places they inhabit?

This broad research question is confined by focusing on the region of Limburg that is of interest due to its political-historical context and particular characteristics. In particular, this research was conducted in the city of Roermond, a city known for its diversity. I carried out my ethnographic fieldwork in three locations: I observed and participated in carnival celebration practices at a carnival association in the former village of Maasniel, I chitchatted with two men on a bench in the city center of Roermond, and I observed grocery practices of staff and customers in a small-scale supermarket in the neighborhood of De Donderberg while working alongside them. For the three research cases, I will analyze 
empirical events that took place during my fieldwork visits to address how people give meaning to the places and people around them through their language practices. These experiences and data from Roermond pushed me, in a grounded theory manner (Corbin and Strauss 1990), in the direction of certain sensitizing concepts that are empirically informed, give guidance in approaching empirical realities and, eventually, help to build analysis (Becker 1998: 3-4; Blumer 1954: 7; Charmaz 2003: 259). Through dialogue with empirical findings, sensitizing concepts may eventually develop new definitions that are more apt in describing social realities (Blok 1976: 34). By making use of sensitizing concepts to analyze the research cases of my ethnographic fieldwork, I address the research question. Those central sensitizing concepts are: center-periphery dynamics, place-making processes, politics of (un)belonging, and foreignness. In this book I further develop insights from sociolinguistic studies into place and place-making (cf. Cornips and De Rooij 2018; Johnstone 2013a) and link these insights with notions of belonging and unbelonging (cf. Antonsich 2010; Christensen 2009; Yuval-Davis 2006). Moreover, this research starts from a perspective that regards language as resource for language practices (cf. Johnstone 2013a; Møller and Jørgensen 2009; Pennycook and Otsuji 2014a).

In this introduction I present the Dutch province of Limburg and the fieldwork location, the city of Roermond. Small empirical snapshots introduce and clarify the main sensitizing concepts given above and introduce the dissertation's perspective on language. This introduction concludes by elaborating on the research cases and structure of the book.

\subsection{The fieldwork location: Roermond}

The city of Roermond, where this research took place, is located in the Dutch province of Limburg. Limburg is located in the southeast of the Netherlands, bordering both Belgium in the west and Germany in the east. Limburg has 1,117,328 inhabitants, of which more than half live in the southern part of the province, according to Statistics Netherlands, Centraal Bureau voor de Statistiek, hereafter CBS (CBS October 2016). Figure 1.1 shows the province (its borders in red) within the Netherlands.

Figure 1.1: Map of the Netherlands with the province of Limburg highlighted in red.

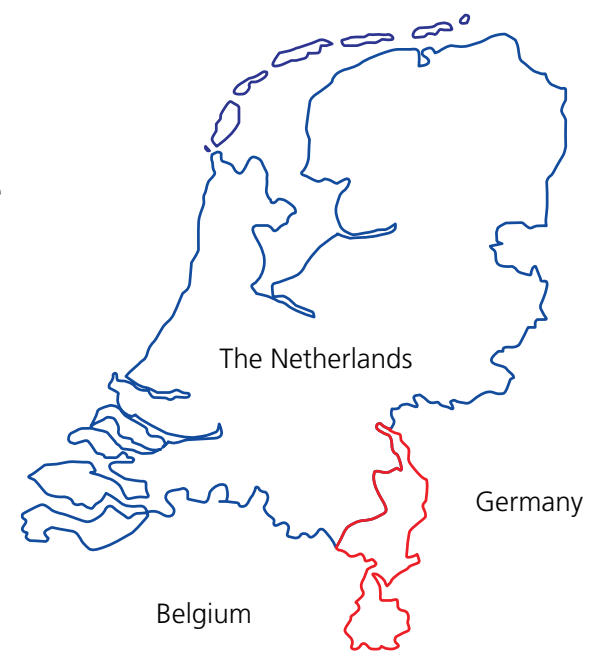


Figure 1.2 shows the province in detail with a select of major cities. The fieldwork location of Roermond is located in the middle (in bold) and the capital of Limburg, Maastricht, in the far left corner, close to the Belgian border. The distance between Roermond and Maastricht is 48 kilometers.

Figure 1.2: Map of Limburg with select major cities, including Roermond which is highlighted in bold.

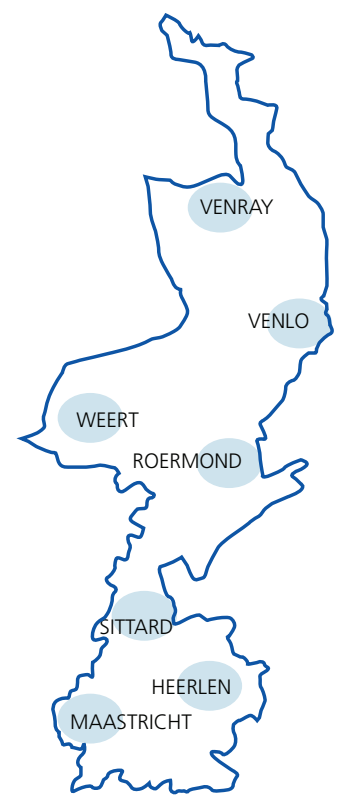

A short history of Roermond follows. In the twelfth century, the then rulers of Roermond settled on the spot where the rivers Maas and Roer meet, in order to collect tolls from passing traders and skippers (Van de Mortel 2012: 44). Travelers gathered and spent time together on what is now known as the city's market square, and it did not take long before hostels, cafes, and trading spots appeared (ibid). At that time, Roermond was referred to as Ruregemunde and Ruremunde. These names are both a composite of Rure and the Latin word mundium, meaning consolidation (ibid), to describe that Roermond was a consolidated place near the Roer River. In the mid-fourteenth century, Roermond was the capital of the upper quarter of the Guelders duchy. For a long time, Roermond remained the region's center, with factories, a court, and the seat of the bishop of the Catholic Church (Wijers 1995: 183). This changed when Limburg became part of the United Kingdom of the Netherlands in 1815 and Maastricht took over the role as capital. ${ }^{1}$ Nevertheless, trade and industry in Roermond survived, and the presence of clerical authorities made it a Roman-Catholic city with a variety of social classes: from the very poor to the exclusive and majestic fraternities (ibid: 184-186).

Nowadays Roermond is a medium-sized Dutch city located in the heart of Limburg (see Figure 1.3). The dialect names used to refer to Roermond are Remunj (mostly used within and near Roermond itself), Remung and Remund.

\footnotetext{
${ }^{1}$ In August 2015, it was decided that the main juridical tasks, which till then were up in the hands of the court of Maastricht, would move to Roermond. Due to this, Roermond will thus become a judicial center within the region again, despite many protests from Maastricht (Dohmen 2015).
} 

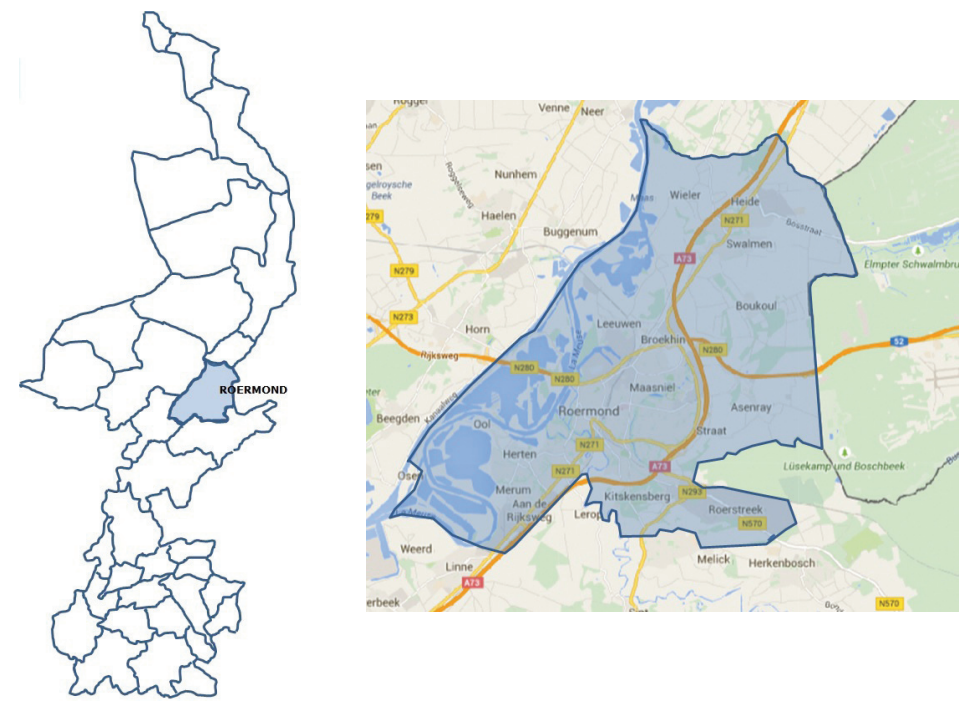

Figure 1.3: Map of Roermond in Limburg and a Google Maps screenshot of Roermond in detail (Image by Google Maps, courtesy of Google Maps). ${ }^{2}$

The municipality of Roermond has 57,010 inhabitants (CBS 2016), who live in thirty neighborhoods, (former) villages, and hamlets (CBS 2011). As a result of local government reorganizations, Maasniel (in 1959), Herten (in 1991), and Swalmen (in 2007) were merged with Roermond. These former municipalities are perceived as districts of Roermond, marked with their own signposts at the districts' borders, displaying both the Dutch and dialect names (see Figure 1.4).
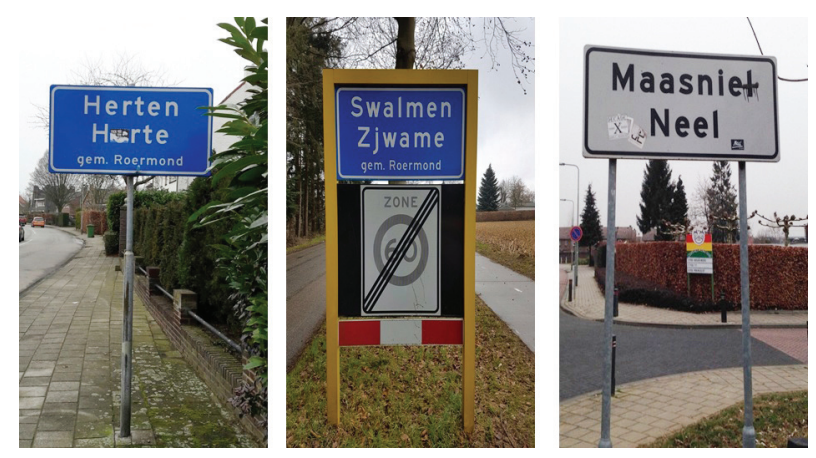

Figure 1.4: Photographs of signposts at the borders of Herten (taken by Sanne Thissen), Swalmen (taken by John Kleijkers), and Maasniel (taken by the author). In all photographs, the dialect names of the places (Herte, Zjwame, and Neel) are given.

\footnotetext{
${ }^{2}$ See https://www.google.com/permissions/geoguidelines.html\#general-guidelines for general guidelines for using Google Maps screenshots for printed materials.
} 
As in earlier days, the city might still be seen as being socially segregated, with large differences in welfare among its neighborhoods, but this holds true for many Dutch cities. Roermond is one of the most diverse cities within the province of Limburg. In Figure 1.5 below, I compare the composition of Roermond's inhabitants with those of the bigger cities of Maastricht and Venlo, the province, and the Netherlands as a whole. Before explaining the numbers, it is important to explain that CBS uses the labels autochtoon to refer to 'native Dutch' persons and allochtoon to refer to 'non-native' persons. ${ }^{3,4}$ For the allochtoon category, there is a difference between so-called 'western allochthones' and 'non-western allochthones' (CBS 2000:101). CBS further distinguishes between first- and second-generation allochtoon, where first-generation applies to people who are born outside the country and have at least one parent born outside the country. Second-generation applies to people who are themselves born inside the country but who have at least one parent born outside the country. In using this nomenclature, CBS was under the impression that it had come up with a neutral definition, however, the labels are highly contested in Dutch society, since they stigmatize people born in the Netherlands coming from a socalled multicultural background (Olgun 2013; Raad voor Maatschappelijke Ontwikkeling 2012; Van de Poll 2015). Moreover, these distinctions and labels do not give any insight into how people affiliate or identify themselves, according to the contexts in which they find themselves. Nevertheless, the numbers in Figure 1.5 provide a rough idea of Roermond's composition:

\begin{tabular}{l|ccccc}
\hline & Roermond & Maastricht & Venlo & Limburg & $\begin{array}{c}\text { the } \\
\text { Netherlands }\end{array}$ \\
\hline $\begin{array}{l}\text { Total } \\
\text { inhabitants }\end{array}$ & 57,010 & 122,533 & 100,371 & $1,117,328$ & $16,979,120$ \\
Autochtoon & $\mathbf{}$ & & & & \\
& $\underline{\mathbf{7 1 . 8} \%}$ & $\underline{\mathbf{7 0 . 1} \%}$ & $\underline{\mathbf{7 3 . 2} \%}$ & $\underline{\mathbf{7 8 . 9} \%}$ & $\underline{\mathbf{7 7 . 9} \%}$ \\
Westerse & 8,353 & 24,009 & 15,573 & 163,493 & $1,655,699$ \\
allochtoon & $\underline{\mathbf{1 4 . 7} \%}$ & $\underline{\mathbf{1 9 . 6 \%}}$ & $\underline{\mathbf{1 5 . 5 \%}}$ & $\underline{\mathbf{1 4 . 6 \%}}$ & $\underline{\mathbf{9 . 8} \%}$ \\
Niet-westerse & $\mathbf{7 , 7 3 1}$ & 12,561 & 11,336 & $\mathbf{7 2 , 3 8 2}$ & $2,096,592$ \\
allochtoon & $\underline{\mathbf{1 3 . 5} \%}$ & $\underline{\mathbf{1 0 . 3}}$ & $\underline{\mathbf{1 1 . 3} \%}$ & $\underline{\mathbf{6 . 5} \%}$ & $\underline{\mathbf{1 2 . 3} \%}$ \\
\hline
\end{tabular}

Figure 1.5: Composition of inhabitants (autochtoon, Westerse allochtoon, and niet-westerse allochtoon) by number and percentage for Roermond, Maastricht, Venlo, Limburg, and the Netherlands (CBS Statline 2016).

\footnotetext{
${ }^{3}$ Within the Anglophone world, the pair autochtoon and allochtoon is not common in referring to people but, rather, to refer to either indigenous (autochthone) or alien (allochthone) plant and animal species, which makes the labels even more suspect.

${ }^{4}$ Initially, the label allochtoon was coined by sociologist Verwey-Jonker in 1971 to refer to people who were born outside the Netherlands and to replace the term 'immigrant.' The label was later used by the Scientific Council for Government Policy (Wetenschappelijk Raad voor Regeringsbeleid, WRR) in the late 1980s to examine and ameliorate the social and economic differences between 'ethnic minorities' and 'natives' (Rodenburg 2015). In 1999, CBS defined allochtoon as those persons who have at least one parent born outside the Netherlands (CBS 2000: 101). This definition still applies but, additionally, CBS now distinguishes among western and non-western and first- and second-generation allochtonen.
} 
The table in Figure 1.5 shows that $14.7 \%$ of Roermond's inhabitants originally come from other Western countries, such as Germany and East European countries, while the average percentage for Limburg is $14.6 \%$, and the average percentage for the Netherlands as a whole is $9.8 \%$. $13.5 \%$ of Roermond's inhabitants originally come from non-Western countries, such as Turkey and Morocco, whereas the average percentage for Limburg is $6.5 \%$, and the average percentage for the country is $12.3 \%$. Moreover, in comparison with the bigger cities of Maastricht and Venlo, the inhabitants of Roermond have more diversity in perceived backgrounds. I write 'perceived' since, obviously, the labeling of autochtoon and allochtoon heavily depends on the criteria one focuses on in population censuses (cf. Broeder and Extra 1996) and on people's ideological beliefs. Yet the numbers reflect the fact that Roermond is among the most diverse cities within the province of Limburg.

\subsection{Limburg: A piece of foreign country in the Netherlands}

In 2008, the Tourist Information Office of Limburg launched a campaign to promote the province. In an advertisement, Limburg is presented as a piece of foreign country - unDutch even - that is only two hours away by car:

Liefde voor het eigen land. Limburg is eigenlijk een stukje buitenland in Nederland. Neem links en rechts wat foto's, laat ze thuis zien en zeg niet waar je was. De reacties: Toscane? Midden Frankrijk? Camping aan de Loire? Ergens in het Moeselgebied? Nee! Limburg is zo on-Nederlands en zo vlakbij. Nog geen twee uur rijden en je bent er al: het vakantiegevoel heb je snel, het genieten kan meteen beginnen. Boek een lange of korte vakantie en voor je het weet ontmoet je de liefde voor het leven. Ontdek het allemaal op www. liefdevoorhetleven.nl.

Love for the homeland. Limburg is actually a piece of foreign country in the Netherlands. Just take some photographs, show them to the people at home and do not tell anyone where you were. The reactions: Tuscany? Central France? A camping site next to the Loire? Somewhere in the Mosel area? No! Limburg is so un-Dutch and so close by. Hardly two hours by car and you are already there: you quickly get the feeling of being on holiday, the pleasure starts right away. Book a long or short vacation and before you know it, you will encounter the love of your life. Discover it all at www. liefdevoorhetleven.nl (Vereniging voor Vreemdelingenverkeer Limburg 'Tourist Information Office' Limburg, 2008, translation is my own).

Presumably, the campaign's goal was to attract national tourists to Limburg, since the exclusive use of Dutch and the time range of two hours by car implies visitors would be coming from Randstad - an area that comprises the four big cities of Amsterdam, Rotterdam, Utrecht and The Hague. After this two-hour drive, a person would quickly experience the feeling of being on holiday. Limburg is imagined as an un-Dutch paradise where other Dutch inhabitants can go if they want to escape the 'real' Netherlands. The advertisement reproduces the common notion that Limburg is regarded as not really being 
part of and is quite different from the Dutch nation-state. This notion is partly due to Limburg's tumultuous history in which different rulers came and went and the shape of the province - as we know it now - changed several times. Its history in a nutshell is as follows: during the Eighty Years' War (1568-1648), most of the southern part of the Netherlands was under Spanish influence, and Catholicism was the only permitted religion (Knotter 2009). Thereafter, the area now known as Dutch 'Limburg' was part of a larger territory including the modern-day areas of Luxembourg and Belgian Flanders that was artificially created by the French administrative force, though it remained a highly contested area that was politically instable and experienced Spanish and Austrian take-overs (Orbons and Spronck 2009: 43-44). In 1815, the southern Netherlands became part of the United Kingdom of the Netherlands, under the rule of King William I. He decided that the areas of modern-day Dutch Limburg and Belgian Limburg should be called 'Limburg,' after the medieval duchy that was once part of the Spanish Netherlands and, later, the United Kingdom of the Netherlands. ${ }^{5}$ In 1839, the two Limburg areas were separated, after which the western part became Belgian while the eastern part became Dutch, though it remained a member of the German Confederation until 1867. From that time forward, Limburg became the eleventh province of the Netherlands, though it retained the name 'duchy' until 1906 (Orbons and Spronck 2009: 35-36).

Limburg's eventual and relatively late integration into the Dutch nation-state in 1867 fostered a strong regionally felt Limburgian identity based mainly on cultural, religious, and linguistic differences in comparison with the rest of the Netherlands. Knotter (2011) has called the integration of Limburg into the Netherlands 'negative integration': it was only after Limburg was absorbed into the Dutch nation-state that a distinct sense of regional identity could develop. Since then, inhabitants have experienced and imagined what they had in common and how they differed from the nation-state to which they, from that moment on, belonged: 'Limburgers' would cherish a joie-de-vivre lifestyle and certain traditions, such as carnival celebration (cf. Cornips and Knotter 2016; Knotter 2009; Wijers 2015). The perceived differences and resulting dichotomy between Limburg and 'Holland' - as the rest of the country is often called in Limburg - is still of great significance in the province today (see Cornips et al. 2012; Mathijsen 2011). The tourism advertisement clearly demonstrated this by portraying Limburg as a foreign country.

\subsection{Center-periphery dynamics}

Portraying Limburg as a foreign country and distinct from the rest of the Netherlands feeds into center-periphery dynamics in which 'center' and 'periphery' refer to, relatively, the core or mainstream region of an area and the area that stands outside or at the edge of a defined space (Hall 2015: 162; Wall 2015: 180). Center-periphery dynamics are driven by ideas that people in a particular place, region or country have about dominant power relations of who is or is not in charge (cf. Giddens 1984; Hannerz 1989; Kearney 1995). This is why peripheries are often, but not always, marginal in the sense that they have to cope with disadvantage and inequality, in comparison to the perceived center (Hall

\footnotetext{
${ }^{5}$ King William I named the new department Limburg because he wanted to include the historical name in his kingdom (Perry 2009: 187).
} 
2015; Wacquant 2008). As a result, "those inhabiting the (perceived) periphery [may] feel marginalized economically, politically, culturally, and linguistically by the (perceived) center" (Wang et al. 2013: 14). The unequally perceived power relations may be reflected in the status or hierarchy of language practices (cf. Cornips et al. 2012; Pietikäinen and Kelly-Holmes 2013; De Swaan 2001). For instance, people in the Netherlands living in the 'center' perceive the variety of Dutch that is spoken in Randstad as the standard, neutral, and dominant variety, whereas they regard peripheral varieties as different and inferior (Cornips in press; Smakman 2006; Van Bezooijen 1997, 2002). A powerful example is that Dutch national television (broadcasting from the Randstad area) usually inserts subtitles for people speaking Dutch with accents that are perceived to deviate from the Randstad norm (Cornips 2014), such as an accent associated with Limburg.

For that reason, perceived peripheries have become popular sites for research on language practices and ideologies (see Cornips and De Rooij 2018; Pietikäinen et al. 2016). Peripheral areas tend to be more pragmatic in terms of 'multilingual' practices and are far more dynamic than is generally assumed (Kelly-Holmes and Pietikäinen 2015): centers and peripheries change, disappear and reappear (Harrison 2015: 173). Moreover, globalizing forces do not just go from perceived centers to peripheries; perceived peripheries have agency themselves whilst creating their own centers as well (Inda and Rosaldo 2008; Tsing 2005). In line with De Lima (2012), I oppose the assumption that peripheries are homogeneous areas where people live in harmony and where diversity is absent. Therefore, instead of mapping the spatial distribution of and dependencies between centers, semi-peripheries, and centers (Krugman 1979; Potter 2001; Schubert and Sooryamoorthy 2010; Wallerstein 1974), it is more interesting to examine how people define and relate to perceived center-periphery dynamics in their everyday interactions and to take a processual and experiential approach to centers and peripheries (cf. Ang and Stratton 1996; Cornips and De Rooij 2018; Pietikäinen et al. 2016). Thus, this dissertation will take into account dynamics of centers and peripheries, such as Limburg versus 'Holland,' to show how boundaries and categories of center and periphery are constructed, negotiated, and challenged through language practices (cf. Pietikäinen et al. 2016).

\subsection{Accents and dialects in Limburg}

People from Limburg speaking Dutch are usually recognized by their accent, as I too experienced during my first night out as a student in Utrecht. My accent would have been non-existent were it not for processes of enregisterment that make accents hearable (cf. Agha 2007, 2008; Johnstone 2013a) through the association of particular linguistic characteristics with Limburg and its inhabitants. Some characteristics that are associated with accents in Dutch in Limburg are the singsong intonation (cf. Hagen and Giesbers

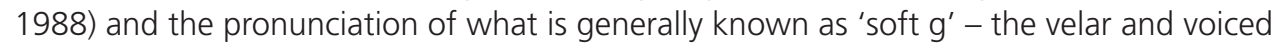
fricative $/ \gamma /$ in onset position ( $y e i t$ ' $g o a t$ ') and velar and unvoiced $/ X /$ fricative in coda position (lax 'laugh') (see Cornips et al. 2012; Grondelaers et al. 2010; Thissen and Cornips 2015). Aside from having accents when speaking in Dutch, people in Limburg may speak local languages or dialects. The Dutch government recognized the dialects in Limburg as an official regional minority language in 1997 based on the European Charter for Minority and Regional Languages (Council of Europe 1999: 32). Despite being recognized as an official regional minority language, Limburg's dialects differ linguistically from each other to a 
large extent at all levels (phonologically, (morpho)syntactically, and lexically), which is why I refer to them in plural form. According to Hermans (2013), two phenomena may be called 'Limburg phenomena par excellence,' since they occur in most Limburg dialect varieties and are nowhere else to be found in the Netherlands, namely the contrast between tonal accent 1 (also called 'push tone') and tonal accent 2 (also called 'draw tone'). Phonetically, the two accents are distinguished as a timing difference (see also Ramachers 2014) resulting in the perceived singsong intonation of people living in and coming from Limburg.

Limburg has a long history of dialect enregisterment (Cornips et al. 2016; Johnstone 2013ab) through which linguistic forms and its users have been associated with specific places and social (stereo)types. $75 \%$ of the Limburgian population, or 900,000 people, claim to use dialects in both formal and informal situations (Driessen 2009: 69). People not only set Limburg apart from the Netherlands through the regional accent in Dutch and the dialects, they also experience and are highly aware of linguistic differences among dialects that are associated with different places in Limburg. They may reflect upon those differences in a metalinguistic fashion (Cornips et al. 2016). My dialect use, for example, was corrected according to the place I found myself in, as shown in the following vignette:

Mar-Li runs Roermondenaar.nl, a website about fellow Roermondenaren (the name for inhabitants of the city of Roermond). I decide to visit her to see if she has suggestions for my fieldwork. Summer is in full swing and through the wide-open door I see Mar-Li, who is sitting at a large table in the middle of her colorful living room. She immediately invites me to sit down and pours a cup of coffee. We start talking, in Dutch, about our backgrounds and our mutual love for the city. Halfway into the conversation, Mar-Li wonders why we do not use dialect, and she immediately switches. She tells me she hates it when people make mistakes in Remunjs (the dialect of Roermond) and that she often corrects people rather bluntly. I just start to explain my research on taol [tb:I] (language) when Mar-Li immediately puts her earlier statement into practice and interrupts: "Taol! Taal [ta:l]!" Embarrassed as I am, I correct myself: "Taal, taol is Mestreechs hè?" ("Taal, taol is from Maastricht, isn't it?").

(Field notes, July 9, 2012)

Mar-Li exemplifies, in correcting me, the heightened metalinguistic awareness of people in Limburg about the differences between dialects. The correction shows that MarLi heard the differences between the used linguistic forms and perceives taal [ta:I] as the correct form and taol [tp:l] as the incorrect form. This practice of correcting has to do with the association of dialectal forms with places and regions within the province: taal is associated with the region of Roermond, whereas taol is associated with the south of Limburg (particularly Maastricht).

\subsection{Place-making processes}

The vignette about Mar-Li demonstrates that people seem to be preoccupied with a strong ideological commitment to talk 'pure' while defining, legitimating, rooting, and safeguarding the authenticity and uniqueness of their 'language' and 'culture' to a place (Cresswell 2009; Duyvendak 2011; Jaspers and Madsen 2016; Olwig and Hastrup 1997). Especially in encoun- 
ters with 'otherness,' people may feel the need to construct authentic and static bonds to a place: only when Mar-Li was exposed to the 'other' linguistic form taol did she feel the need to correct me in order to safeguard 'the' dialect of Roermond. 'Place' is thus far from unimportant in this globalizing and seemingly shrinking world (Bauman 1998; Harvey 1990; Inda and Rosaldo 2008) in which place gets highly politicized (Amin 2002; Lawrence-Zúñiga 2003; Massey 2005; Paasi 2001; Pierce et al. 2010). Studying how people give meaning to the everyday places they inhabit then requires examining "how (...) understandings of locality, community, and region [are] formed and lived" (Gupta and Ferguson 1997: 6) instead of perceiving locality and 'peoples and cultures' as obvious and "succumbing to a nostalgia for origins" (ibid: 7).

The concept of place-making processes enables exactly this, since it presupposes a difference between absolute space, which is a point on a map with specific coordinates and a fixed distance from other points, and social space, which is always constructed through people's social activities (Lefebvre 1991). Place-making entails the transformation of absolute space into social space or into 'lived' and socially produced places (Cresswell 2009). People make places through their practices and the attachment of ideas to places about what behavior is appropriate and what is not (Cresswell 1996: 16-17). Pred (1985: 337) argues that place, therefore, "represents a human product; it always involves an appropriation and transformation of space and nature that is inseparable from the reproduction and transformation of society in time and space." Place-making is, in other words, about the ways that people appropriate particular locations while endowing these with social meaning in the form of linguistic and cultural and/or material objects (see Feld and Basso 1996 and Low and Lawrence-Zúñiga 2003 for brilliant ethnographic accounts on place-making).

With the three research cases at hand in this dissertation, I aim to let go of the idea that clearly bounded 'peoples,' 'cultures,' and 'languages' reside in fixed locations with their own traditions and practices (cf. Gupta and Ferguson 1997). Instead, I will examine how people appropriate spaces around them through their practices and show that it is through place-making processes that particular behavior and persons are perceived to be in place while others are perceived to be out of place.

More specifically, I am interested in linguistic place-making processes. The Mar-Li vignette exemplifies how people in Limburg try to safeguard an authentic dialect by the practice of correcting while, more important, attaching particular linguistic forms to particular places, thus endowing that place with meaning through everyday practices. As such, Mar-Li's correction exemplifies the relation between two forms of place-making processes that are different in scope. On the one hand, processes of place-making can be directed at particular locations as a whole (villages, cities, regions, countries) and link these locations with particular linguistic and cultural forms and ideological beliefs, thereby transforming it into a lived place. This form of place-making is reinforced by enregisterment processes (Agha 2007, 2008; Johnstone 2013a) that feed the normative association of linguistic forms with particular places on a map. Johnstone's research (2010, 2013ab, 2014) in Pittsburgh explains how linguistic forms become indexical of and enregistered with a place like Pittsburgh, thereby focusing on processes of place-making:

Rather than asking about how speech co-varies with psychical location, we are beginning to ask how meaningful places are constructed in speech and other forms of interaction, how people experience place, and how the use of one set of linguistic variants versus another can result from and contribute to these processes (Johnstone 2013b: 110). 
So, instead of pinpointing 'languages' on maps, Johnstone questions how places are collectively constructed via talking, writing, and other aspects of social interaction and how people experience language and linguistic variation (Johnstone 2013a: 36). Her research reveals how linguistic forms are enregistered as a local dialect. When people hear these forms, this may evoke a sense of place (ibid: 37). Through these broader processes of place-making, people construct a particular discourse that is commonly believed to be true, even though it might be stereotypical. The same holds true for Limburg, where a velar fricative and dialects are associated - by both its users as well as by others - with the province and ideological beliefs and stereotypes about the users of these linguistic forms. From the Mar-Li snapshot, it becomes clear which linguistic form is enregistered with the city of Roermond: taal, not taol.

The second form of place-making processes arises from people's practices, activities, and interactions with others in everyday situations and locations. An example of this is the unwritten rule between people to speak and behave in a specific manner in a particular place. In this form of place-making, it is more about how people actually appropriate locations and feel at home (or not) in a particular location. Language is regarded as being a vital aspect in these place-making processes (see Basso 1996; Csordas 1994; Duranti 1997b; Johnstone 2013; Low 2003; Valentine et al. 2008; Tuan 1991). Based on Ricoeur (1991), Csordas (1994: 11) argues that "language not only represents or refers but 'discloses' our being-in-the-world." In order to study how people give shape to this being-in-the-world, Low (2003: 16) encourages taking into account "Duranti's (1997b) integration of language, body movement, spatial orientation, inhabited space, and distant homelands as expressions of cultural connectedness and socialization." This suggests that the study of language practices and place-making informs how places are endowed with meaning, such as conventions and rules of behavior. Mar-Li's correction of taol [tb:l] to taal [ta:l] discloses her conventions and rules of language practices within the specific context of Roermond. Moreover, the study of place-making practices provides insights into how people connect with as well as disconnect from others in a particular location.

\subsection{Politics of (un)belonging}

In correcting my dialect use, it became clear which linguistic forms, and perhaps also users of these forms, Mar-Li perceived as in and out of place within Roermond. Linguistic placemaking processes thus seem to stimulate the creation of ideas and conventions about what language practices are regarded as appropriate, accepted, and 'normal': who or what is in and out of place. This seems to be very relevant in these times when the question of who belongs to a place and who should be considered as 'the other' or 'outsider' is often raised (cf. Davis and Nencel 2011; Duyvendak 2011). I therefore link processes of place-making to personal feelings as well as interpersonal claims and contestations of (un) belonging.

Antonsich (2010) and Yuval-Davis (2006) have distinguished two analytical levels of belonging: belonging as a personal, intimate feeling of being at home in a place, which Antonsich (2010: 645) calls place-belongingness, and belonging as a discursive resource that constructs, claims, justifies, or resists forms of socio-spatial inclusion and exclusion. The latter refers to the so-called politics of belonging (Antonsich 2010: 645; Yuval-Davis 2006: 204, 2007) that involves "the dirty work of boundary maintenance" (Crowley 
1999: 30 in Yuval-Davis 2006: 204). Place-belongingness and the politics of belonging are intertwined, since the latter obviously influences the place-belongingness of a person. This double-edged concept of belonging allows me, due to its inherent multiplicity, to capture the dynamicity and messiness of belonging, which is created by the intersection of the different positions and categories with which people align (hooks 1982; McCall 2005; Yuval-Davis 2007). Others have used the terms 'modes of belonging' (Sicakkan and Lithman 2005) and 'differential belonging' (Rowe 2005) precisely to highlight the contextdependent and shifting nature of belonging and "the endless variety of attachment to places, groups, cultures, etcetera" (Antonsich 2010: 645).

In line with Cresswell (1996) and Savage et al. (2005), I deliberately include 'place' in studying the construction and experience of belonging in order to elucidate my empirical material from the three research cases. This means that I aim to show how placebelongingness as well as politics of belonging are enacted through practices within certain places instead of examining, for example, a person's belonging to Limburg. The ways that people relate to places are, however, never preset: "Belonging is not that of an individual to a fixed community rooted in place, but rather, one in which a place becomes valuable to the individual" (Savage et al. 2005: 80). I thus believe that people continuously redefine their feelings of belonging within and to the places in which they live by enacting their belongingness in certain situations in relation to and with other people, instead of regarding belongingness as a final state-of-being that can be achieved (cf. Youkhana 2015; Yuval-Davis et al. 2006). It is partly through the earlier discussed dynamics of center and periphery that belonging and unbelonging are processual and continuous, since they require people to relate to perceived centers and peripheries, depending on place, time, and situation.

Yet Christensen (2009: 23) rightly points out that politics of belonging is as much about belonging as it is about unbelonging. To her, belonging is not only about the collective and the individual, but also about distinction and social exclusion. Politics of belonging can thus be a sensitive topic for both those people who 'belong' as for those who are considered or judged to 'unbelong.' Throughout this book, I will use the merged concept

politics of (un)belonging, including both the feelings and the contestations of belonging as well as the exclusionary dimension of unbelonging. With this concept, I aim to capture how people experience, claim, defend, contest, and negotiate belonging and, inherently, unbelonging by means of the place-making processes they devise within the places they inhabit (Thissen 2015). The combined study of language practices, place-making and belonging theory enables me to address the research question, providing insights into the ways people give meaning to the everyday places they inhabit and how they affiliate with or distance themselves from others in these places through language practices by deciding who and what behavior is considered in and out of place. The research cases demonstrate how belonging and unbelonging are played out in the situated interactions of people.

One could ask why I do not use the much more common term 'identity.' The post-modern and deconstructed concept of identity assumes that identifications are fluid, multiple, and dynamic. My conception of belonging fully underscores this and agrees with the idea that no one person has a stable feeling of belonging across a full spectrum of different times, contexts, and situations. Yet, "once deconstructed, what then?" (Bhamra 2006: 32): if everything is fluid and dynamic, what is there still to say about the ways that people relate to and distance themselves from each other on the basis of language and cultural practices? Anthias (2002: 493) rightly argues that identity is "a disabling concept 
that limits the focus and moves the analyst away from context, meaning and practice." The understanding of identities as fluid and dynamic is, in other words, too vague and ephemeral and fails to provide concrete methods to analyze the everyday building of social relations. Bucholtz and Hall (2005: 585-586) are among the few who have come up with practical ways of analyzing the linguistic construction of identity as "a relational and sociocultural phenomenon that emerges and circulates in local discourse contexts of interaction" by looking at the emergence, positionality, indexicality, relationality, and partialness of identity constructions. Still, the mere use of the word 'identity' seems unsatisfactory, since it presupposes identification with homogeneous collective units that reproduce groupist assumptions and fundamental sameness (Brubaker and Cooper 2000). I therefore have deliberately chosen to use feelings of belonging and unbelonging, since this concept leaves space for the messy and lived contradictions, ambiguities, and blurring social boundaries, where identity does not.

While 'identity-talk' is real and important in imagining bounded communities (cf. Anderson 1983), Brubaker and Cooper (2000: 5) warn us about using identity as a category of analysis: "just as one can analyze (...) 'race-talk' and 'race'-oriented politics without positing the existence of 'races,' so one can analyze 'identity-talk' and identity politics without, as analysts, positing the existence of 'identities'." My focus on politics of (un)belonging within particular situated interactions in places is, in my view, a way to go beyond identity (cf. Brubaker and Cooper 2000), since this concept deals with "commonness, not necessarily sameness" (Pfaff-Czarnecka 2011: 4), as does identity. This commonness can be experienced by engaging in similar everyday language and cultural practices but also by "jointly taking things for granted and sharing common knowledge and meaning" (ibid: 5). Politics of (un)belonging enables me to say something more substantial about the everyday and various workings and continuous negotiations of belonging and how this relates to place-making and language practices in current globalizing times.

In hindsight, then, it is possible to interpret the butcher's assertion from the beginning of this introduction as a way to claim, challenge, and negotiate belonging and unbelonging in a situated interaction:

When asking me whether I am a foreigner too, I answer that I am 'half.' The butcher responds: "Half bestaat niet meer, dan ben je buitenlander" ("Half does not exist anymore, then you are a foreigner").

(Field notes, December 17, 2012)

The butcher seems intent on figuring out whether we have 'something' in common so that we can bond. This 'something' is being a 'foreigner' or not. Generally, 'foreigner' (buitenlander) is used by so-called 'natives' in the Netherlands to refer to, often in pejorative ways, 'the other' or 'the non-native' or those people who, in other words, are not perceived as originally belonging to the Netherlands. By using the word "foreigner," I argue that the butcher tried to negotiate a shared feeling of belonging together that is, however, based on feelings of unbelonging in being a foreigner, too. Moreover, after I claimed to be "half a foreigner," the butcher challenged this by saying that "half does not exist anymore," and he decided that I am indeed a foreigner, thereby emphasizing our commonality (cf. Pfaff-Czarnecka 2011). This is one of the many anecdotes from the supermarket that inspired me to develop foreignness, a concept that aims to reflect how feelings of being out of place or unbelonging at the same time sustain feelings of belonging among 
those who also feel a sense of unbelonging. It is thus a form of belonging through unbelonging. Since foreignness is so strongly grounded (Blok 1976; Corbin and Strauss 1990) in the empirical material from the supermarket, I will fully define the concept of foreignness later. The concept will, however, turn out to be valuable for all three research cases explored in this book.

\subsection{Language as resource in spatial repertoires}

Instead of regarding language practices as the use of clearly defined aggregates of linguistic forms (such as vocabulary, grammar, phonology, and (morpho)syntax) that people fully acquire, this book understands language as resource, where people are languaging (Jørgensen et al. 2011; Møller \& Jørgensen 2009) by drawing upon linguistic forms depending on their communicative goals, situations, places, and the moments in their life (cf. Ahearn 2001; Blommaert 2010). Wiese (2013: 3) makes it clear how people use language by imagining that speakers make use of a pool where competing linguistic forms coming from different sources in contact situations swim around. This pool supports the speaker in creating a pond "according to a particular context where different communicative situations (...) favor certain feature choices [drawn from the pool, LT] over others." This is in line with Møller and Jørgensen (2009:148), when they assume that "speakers have knowledge of features, and that speakers use these features. This is the basis for interaction, the concept of 'language' is not" (their italics). Similar to 'identity,' one can analyze 'languagetalk' without positing the existence of 'languages' (cf. Brubaker and Cooper 2000: 5). Throughout the book, I will use the term linguistic forms to refer to what Wiese (2013) and Møller and Jørgensen (2009) call features. The following empirical snapshot exemplifies this perspective on language as a resource from which people draw linguistic forms:

After a long day of writing my research proposal for my Ph.D., I plump down in one of the last available seats on the train from Maastricht to Roermond. In front of me sits a man in his twenties with dark hair, bronze skin, and brown eyes. I gaze at the hills that pass by outside and am disturbed by the ringing of the man's telephone. My ears take a while until they are tuned towards what is being said in front of me; my brain takes even longer to realize that my research topic, language as resource, is right in front of me:

"Vano[x]tend, ik had me bijna verslapen man. Ik kon niet slapen en heb de hele na[x]t li[y]en rollebolle! Wallah, vet [y]rappi[y], ik steeds snooze, ineens is het tien voor zeven! Maar het werk is prima, $\uparrow$ meer dan $\downarrow$ uitstekend. Ik verdien [getallen

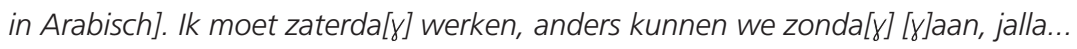
safi, Insha'Allah. I[x] bin er zoe."

"This morning, I almost overslept, man. I could not sleep, and I was tossing and turning the whole night! Wallah, very funny, I snoozed, suddenly it is ten to seven. But the job is fine, even outstanding. I earn [figures in Arabic]. I have to work on Saturday, but we can go on Sunday, jalla... safi, Insha'Allah. I'll be right there." (Telephone conversation of a man on the train from Maastricht to Roermond, October 12, 2011) 
Despite the language as resource perspective, linguistic forms are in fact ideologically associated with labels for languages and dialects in everyday language practices: people associate hallo, hola, and hello with Dutch or German, Spanish, and English respectively. Looking at the linguistic forms used by the man, people would generally agree that he uses a regional variety of Dutch that is associated with Limburg, due to the use of the velar voiced and unvoiced fricatives $([\gamma]$ and $[x]$ respectively) and the use of a melodious or singsong intonation (see $\uparrow \downarrow$ ) (cf. Hagen and Giesbers 1988). Other forms in the man's speech are associated with (Moroccan) Arabic (wallah, the figures in Arabic, jalla, safi, and Insha'Allah), with English (snoozed), and with a dialect from Limburg (ich bin er zoe).

The example shows that fixed connections between language, place, and speakers can become untied (cf. Quist 2010), since a person may use linguistic forms, within only one telephone conversation, that are associated with different languages. Moreover, the man on the train is one of countless examples showing that 'languages' and 'dialects' are cultural constructs that are "produced by a group of people using, orienting to, and/ or talking about, a particular set of linguistic features, in a process that also constructs the group itself" (Johnstone 2013a: 43). Nevertheless, in their everyday language use, people do refer to languages and dialects as coherent and stable structures (Møller and Jørgensen 2009). So, even though we are all aware of the fact that we use many different linguistic forms throughout our lives, people usually still fix themselves and others to the bounded entity that is called ' $a$ ' language, which is, in turn, pinned onto a place on the map (such as Dutch spoken in the Netherlands). When considering how people give meaning to their relations with others and to the places they inhabit through language, it is important to keep in mind that there is a distinction between what we say and believe we do (i.e., speaking only 'proper' Dutch) and what we actually do (i.e., using ranges of linguistic forms). My own thoughts while eavesdropping on the man clearly demonstrate this:

I realize that I look at the man as if he is an exotic creature. How can this guy, with his dark hair and eyes, use linguistic forms that are commonly recognized as a regionally flavored variety of Dutch, Arabic, and dialect in just one conversation? While thinking this, I tend to forget that my own dark hair and eyes, in combination with my ability to speak dialect, are surprising to others as well.

In this book, I will examine people's actual language practices within contexts of use (cf. Gumperz 1992) rather than bounded language blocks, yet I will also take into account people's everyday tendency to believe that languages are clearly bounded entities and that people's 'language' and 'identity' depend on the place they come from and their appearance.

The notion of spatial repertoires, coined by Pennycook and Otsuji (2014a, 2015), is of use when considering the role of language practices in place-making processes and politics of (un)belonging. In arguing that the locus of language lies outside the individual alone, the authors look rather at the production of spatial repertoires "in which linguistic resources become available in relation to the activities, people and organization of particular places" (ibid: 180). The notion does not imagine "people or places to be containers of linguistic resources, but rather are part of a constant push and pull of interactively achieved repertoires" (ibid: 171). This is why this research deliberately uses locations as a jumping-off point rather than focusing on categories of people and language blocks. I will examine how people that engage in these locations produce spatial repertoires through their language practices. Yet, where Pennycook and Otsuji only examine the production 
of spatial repertoires (what linguistic forms do people ascribe to themselves, others, and places?), I will go beyond the production by also including the social meaning of spatial repertoires (what does it mean that people ascribe certain linguistic forms to themselves, others, and places?).

\subsection{Linguistic diversity in Roermond}

As in the rest of Limburg, people in Roermond use dialect in their daily activities. The sentence "in Remunj loupe de hunj mit de kunj euver de grunj" (literally, "in Roermond the dogs walk with their asses on the ground") can be seen as a shibboleth for the city of Roermond because of the palatization or softening at the ends of words through [n], a linguistic form that is indexical (Eckert 2008) of Roermond. Apart from that, the dialect of Roermond is believed to be the most comprehensible dialect variety within the province. A well-known Dutch sociolinguist/dialectologist told me at the very beginning of my research that Roermond is boring, since its dialect does not have any exciting or 'odd' forms compared with other dialects in Limburg, which also makes it understandable to most of the province's dialect speakers. This corroborates the decision of the respected Bond van Carnavalsvereniging Limburg (Confederation of Carnival Associations) to select, from 1984 onwards, the dialect of Roermond for writing in their magazine, which is distributed provincewide, and on carnival awards. They too believed that the Roermond dialect would be the most comprehensible one throughout the province (Wijers 1995: 55-56). The reason that I chose Roermond as a fieldwork location was, aside from having been born in this city myself and thus knowing my way around, because inhabitants and visitors of Roermond use a range of linguistic forms. Within the city one may hear linguistic forms that are commonly associated with Dutch, dialects from Limburg, German, Chinese, English, French, (Moroccan) Arabic, Turkish, Kurdish, Sranan Tongo, Tamil, Polish, and many others. What linguistic form one hears strongly depends on where one is, which is due to placemaking processes. For example, the Designer Outlet Center located in the city center of Roermond attracts many tourists from Europe and Asia. This influences the attachment of linguistic forms to this place, as shown on the touristic guidepost in Figure 1.6

Figure 1.6: In 2015, touristic guideposts were put up in the city center of Roermond to show tourists how they can explore the city and what the main sights are. Dutch, English, German, French, and Chinese were used for these guideposts (August 18, 2015, photo made by the author).

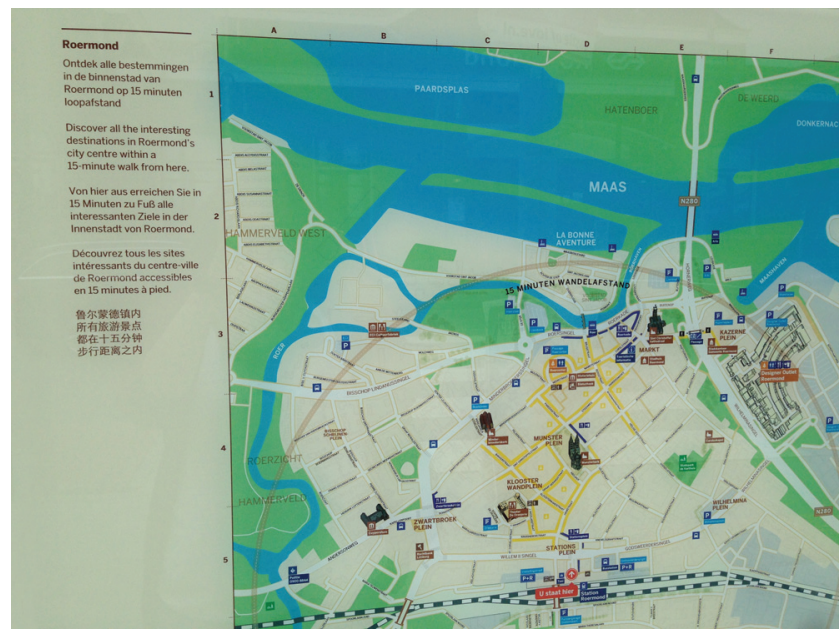


On the guidepost in the city center, linguistic forms are used that are commonly recognizable as Dutch, English, German, French and Chinese. The decision to display the linguistic forms in this specific hierarchy of five languages on the left in the display (first Dutch, then English, German, and French, and Chinese last) is significant, since it shows that this guidepost aims at reaching a large audience that potentially understands the message. Much thought and effort were put into this guidepost: it is a solid official municipal billboard with glass protecting the map, and it was placed in front of Roermond's train station so that people could not miss it. The following sign (Figure 1.7) that I found during Sjommelmert ${ }^{6}$, the yearly two-day flea market that covers large parts of the city center, stands in stark contrast with the multilingual municipal guidepost:

Figure 1.7: Handwritten sign during Sjommelmert in Roermond (July 25, 2012, photo by the author).

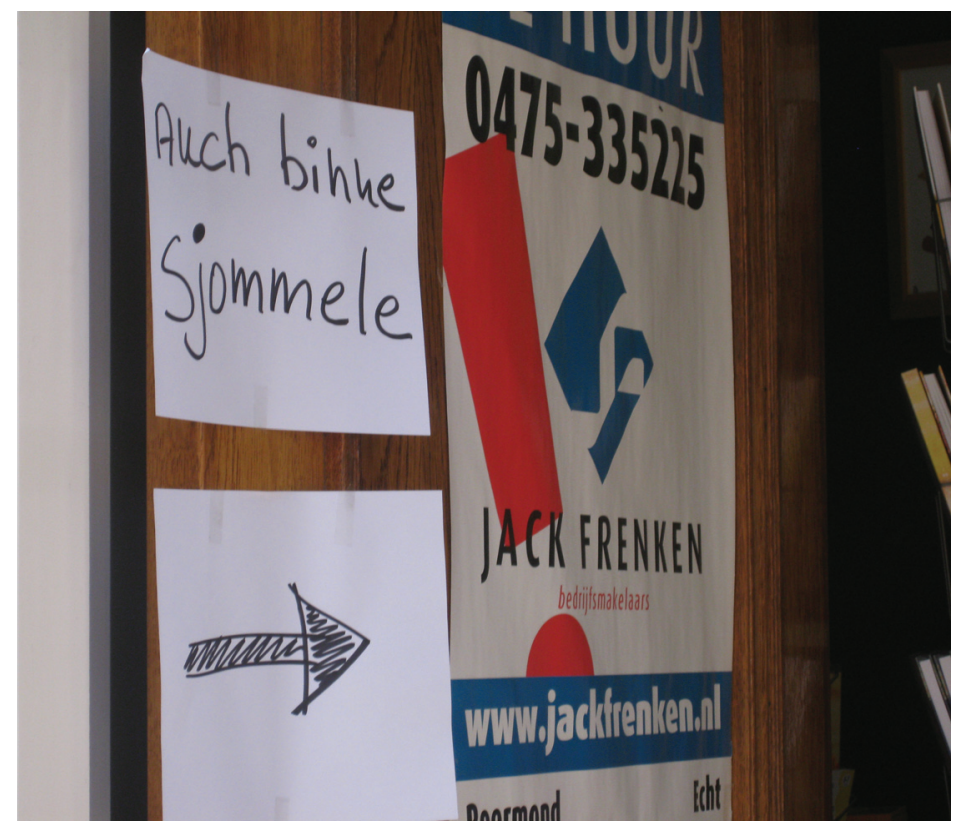

The sign says, using dialect only, auch binne sjommele, which means 'bargainhunting inside too' with an arrow pointing inside. The sign was clearly handwritten on two pieces of paper and hung on the door of a small store located on a side street of the main street where Sjommelmert took place and could thus be regarded as a periphery within the city center (cf. Inda and Rosaldo 2008; Tsing 2005). This handwritten sign is informal compared to the solid glass guidepost (Figure 1.6). Moreover, the handwritten sign was easily overlooked by passers-by and even when they might have seen it, they would have had to be able to read dialect in order to understand the sign, while the guidepost was harder to miss and understandable to a wider audience. As a result, the handwritten sign potentially excludes those who might well be interested in sjommele (bargain hunting) inside the shop, whereas the guidepost excluded those able to read and understand dialect as well as many other linguistic forms.

\footnotetext{
${ }^{6}$ The dialect word sjommelmert is a combination of the verb sjommelen (bargain-hunting) and the noun mert (market) (Sjommelmert n.d.).
} 
Although I did not witness how people dealt with the two signs in Figures 1.6 and 1.7 , it is possible to say that both signs, in conveying messages to particular audiences at different times and locations within the city center, gave shape to politics of (un)belonging that include certain people while excluding others by making distinctions between who and what language practices are in place and out of place. The fact that the signs included some linguistic forms and excluded others informs about the beliefs behind the decisions about who belongs and who does not. Moreover, the signs may be regarded as instruments of place-making processes, since they attach particular linguistic forms to a space, thus transforming it into a lived place (cf. Cresswell 1996; Pred 1985). The guidepost and sign show that 'linguistic landscapes' - a term used to refer to the display of linguistic forms in public spheres (Landry and Bourhis 1997) - of Roermond may include many linguistic forms. These linguistic landscapes, in turn, influence the actual language practices of people who move within them and shape spatial repertoires (Pennycook and Otsuji 2014a) by using particular linguistic forms in particular places. Its diversity makes Roermond an interesting place in which to study how people relate to particular locations in the city, engage with the people they encounter, and the role that language practices play in this.

\subsection{Research cases and outline of the book}

Leeve Heer, laot mich nog heel lang laeve, en laot mich mitdoon tot de allerletste runj, det ich de kienjer van mien kienjer mit kan gaeve, det 't good is om te laeve in Remunj.

Dear God, let me live long, and let me join in until the very last rounds, so that I can pass on to the children from my children, that it is good to live in Remunj.

(Leefde veur de sjtad/Love for the city, text and music by Arnold Wassen n.d.)

This song glorifies that it is good to live in Remunj, Roermond. But how exactly do people in this city give meaning to the places they inhabit within Roermond by engaging in language practices?

To address my research question, I conducted ethnographic fieldwork in Roermond for almost a year in three locations. In Chapter $\mathbf{2}$ I will address how I started my fieldwork in Roermond. In this chapter, I will elaborate on the tradition of linguistic anthropology, clarify the deliberate departure from locations, and expound on the methods of data collection and analysis used. I want to stress that ethnographic fieldwork should be considered as a reflexive place-making process itself where the ethnographer learns with and through research participants and locations, instead of about. This is why I started this dissertation with a vignette about my own background and experiences, since I am both the researcher as well as the research instrument.

This dissertation focuses on three research cases in Roermond: carnival celebration at the carnival association of De Katers (The Tomcats) from the former village of Maasniel, an interaction between David and Zeegert, two men sitting on a bench on Munsterplein 
plaza in the city center, and grocery practices at the Dost Market supermarket located in De Donderberg neighborhood. ${ }^{7}$ Figure 1.8 shows the locations of the three fieldwork sites within Roermond.

Figure 1.8: Map of Roermond with fieldwork sites highlighted (Image by Google Maps, courtesy of Google Maps).

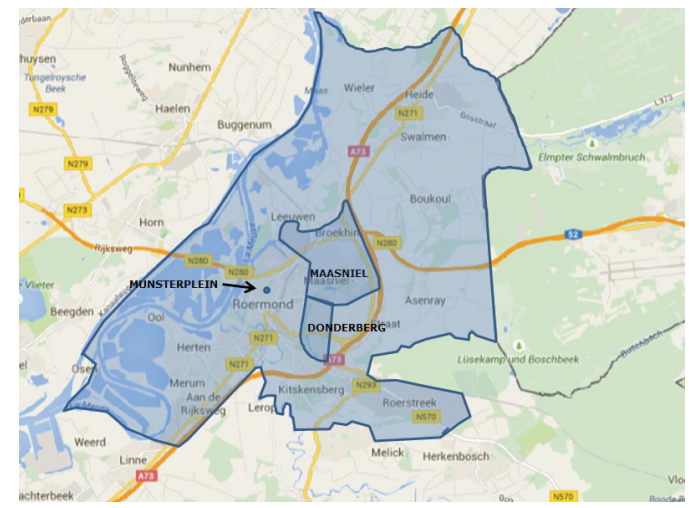

My fieldwork at the carnival association and the supermarket covered several months, while the encounter with the two men on the bench was a one-time thing. In order to do justice to the fieldwork time in the carnival celebration and supermarket practices, there are separate chapters that provide contextual background for both research sites. On the basis of the empirical findings and their analysis, it will be possible to deal with and reflect on the earlier described sensitizing concepts (cf. Becker 1998; Blok 1976; Blumer 1954; Charmaz 2003): center-periphery dynamics, processes of place-making (in and out of place), politics of (un)belonging, and the newly coined notion of foreignness. Even though all of these concepts will be of relevance throughout the dissertation, some concepts will be more central in particular chapters than in others, as I clarify in the outline below.

Part I pulls the reader along in a polonaise into the exuberant world of carnival celebration, a celebratory tradition that is believed to be a prototypical aspect of the strongly regionally felt Limburgian identity. The fact that the celebration of carnival is generally imagined as the heyday for 'the' strong regional identity and the dialects of Limburg was one of the main reasons that I wanted to include carnival celebration in this research. Moreover, it is in these carnival celebrations that carnival associations engage in carnivalesque and playful rivalries. These rivalries are specifically expressed during speeches at carnival receptions and by means of clothing and symbols. This makes the celebration of carnival within a carnival association in Limburg an interesting field of research for this study on the role of language practices in meaning-making processes shaped within places and the construction of feelings and ideas of who is in and out of place within a particular place. The particular choice of De Katers carnival association was motivated by the history of Maasniel, the formerly independent village with which De Katers is affiliated. Maasniel was

\footnotetext{
${ }^{7}$ In the following chapters, I will refer to the carnival association as 'De Katers carnival association' and to the neighborhood where Dost Market is located as 'De Donderberg neighborhood.' In these phrases I deliberately leave out the article 'the.' I do this because in both names de is the Dutch equivalent of the English article 'the.' In order to avoid double constructions (such as 'the De Donderberg neigborhood' or 'the De Katers carnival association'), I will omit the English article throughout this dissertation.
} 
annexed, as members of De Katers called it, in 1959 by the city of Roermond. This historical occurrence lies, to this day, at the base of the widely propagated dialect motto of De Katers, Neel blief Neel (Maasniel remains Maasniel). In Chapter 3, I will explain how I went about starting my ethnographic fieldwork at De Katers carnival association, where loud events and dances take place that present challenges to making sound audio recordings. Besides this, the chapter provides context in understanding carnival celebration in Limburg and introduces carnival as it is celebrated by carnival associations with their specific structures, ranks, and events. Chapter 4 specifically deals with the place-making processes and practices that I observed at De Katers carnival association. I will point out how members of De Katers use the association's history to appropriate their place of residence, Maasniel. I will show that the historical annexation of Maasniel by the city of Roermond (1959) is still, after more than fifty years, of great significance today in place-making practices that relate to center-periphery dynamics between Maasniel and Roermond, between De Katers and other carnival associations, but also between locations within the area of Maasniel. Within the carnival celebration of De Katers, I show that there are many (linguistic) place-making processes and practices to be found that distinguish and reproduce Maasniel as an independent place with a strong identity. In Chapter 5, then, I will focus on how a language choice between two varieties, Dutch and dialect, came into being and was employed during a specific carnival event at De Katers carnival association. The aim of this chapter is to account for the impact of this language choice on processes of place-making. Moreover, the carnival celebration case will show how, in the choice between Dutch and dialect, different center-periphery dynamics on the nation-state scale of the Netherlands and the regional/local scale of Limburg and Roermond are played out and deployed, thereby shaping politics of belonging as well as unbelonging.

Part II lets the reader sit down on a summer's day next to two men on a bench at Munsterplein plaza and take part in their everyday chitchatting. I include this specific research case in my dissertation, because the men immediately claimed at the beginning of our conversation: "We are no Limburgers." I will make clear in Chapter 6 that this is a remarkable claim, especially because both men spoke with an accent that could be interpreted as regional and local in Limburg. For this study which examines the ways that people express their feelings of belonging and unbelonging within particular places, this conversation with the two men was therefore an interesting one to include. By closely analyzing our conversation, I show how these two men engage in place-making practices that make them feel in as well as out of place within Limburg and Roermond. The situated interaction demonstrates how two men lack feelings of belonging in their so-called 'native' country, while at the same time questioning my belonging as well.

Finally, Part III will take the reader out for grocery shopping at the Dost Market supermarket, located in De Donderberg neighborhood of Roermond, where we will hear the butcher recommend his products to customers in different languages while the smell of fresh and crisp Turkish pide bread reaches our nostrils. De Donderberg neighborhood is generally perceived by people of Roermond as a diverse neighborhood where people with different backgrounds live in close proximity to each other. It is at Dost Market that these people encounter one another when shopping for groceries while making use of linguistic forms that are associated with different languages. As such, the research case of Dost Market provided insight into, first, the ways that people use language in their practices to give meaning to a place such as Dost Market by attaching linguistic forms and formulating ideas about what is considered to be appropriate behavior and what is not. Second, the 
research case demonstrated how people deal with each other and how they express and shape feelings of belonging and unbelonging through their interactions. In Chapter 7, I will introduce the supermarket's location in De Donderberg neighborhood, its staff, and the store's product assortment. Chapter $\mathbf{8}$ starts off by developing the concept of foreignness, based on my fieldwork experiences at Dost Market. After this, the chapter further focuses on place-making practices within the store and the ways that language as a resource is used both in display as well as in situated interactions. The analysis of a situated interaction between a staff member and customer, in Chapter 9, specifically exemplifies how people employ linguistic forms to claim, legitimize, and challenge politics of (un)belonging.

The concluding Chapter 10 answers the research question of this dissertation by recapitulating its main findings and drawing comparisons among the three research cases. I elaborate on the four central conclusions that I want to make in relation to the sensitizing concepts of this dissertation. Moreover, I reflect on how the concept of foreignness, initially developed to explain data from the supermarket, is relevant to the other research cases as well. Aside from that, I stress the relevance of this research for academia and provide recommendations for society as a whole and the ways we deal with each other in our daily interactions. After providing suggestions for future research, I clarify why I decided to title this dissertation Talking in and out of place by returning to my central argument. 


\section{Chapter 2}

\section{Ethnographic methodology}

\section{Introduction}

This dissertation addresses the question of how people, by engaging in language practices with other people, give meaning to the everyday places they inhabit. In addressing this research question, ethnographic methods were indispensable not only in obtaining insight into the actual language practices of people, instead of their reported language use, but also, initially, in discovering potential fieldwork sites. Moreover, the key ethnographic aspect of participating in the practices and activities of people in certain locations in Roermond during fieldwork allowed me to have first-hand observations of and interactions with the ways that people make meaning of their surroundings. Ethnography studies not only what people say or report they do but especially what people actually say and do in a particular location (Malinowski 1929) to find out in that location 'how things go around' (cf. DeWalt and DeWalt 2002).

I decided to conduct fieldwork in Roermond for three reasons. First, the city was a fascinating site in which to gather data because of its diversity (see Chapter 1, Figure 1.5); second, I was born and raised in the city and already knew my way around there; and, third, during the first two years of my Ph.D. I was living with my parents in Roermond again, which made it easy to stay informed about local news and events and to 'hang around' on a daily basis. Within Roermond, I carried out ethnographic fieldwork in different locations in order to address how people give meaning to their everyday surroundings through language practices with others. For this dissertation, I limited myself to the discussion of three research locations: carnival celebration practices in Maasniel (Chapters 3, 4, and 5), chitchatting with two men on a bench in Roermond's city center (Chapter 6), and grocery practices in a supermarket in De Donderberg neighborhood (Chapters 7, 8, and 9). I wanted to deal with these particular research cases, since each of them provides yet another angle on the research question. I wanted to include carnival celebration practices in order to determine whether there is a correspondence between the language practices reproduced in carnival events (see Cornips and De Rooij 2015; Cornips et al. 2012) and the strong regionally felt and imagined identity of Limburg and its association with carnival celebration (see Wijers 1995). I decided to study carnival practices within the confines of a carnival association, since language use is much more institutionalized in this form of carnival celebration than in carnival celebrations on the streets and in cafes (see Chapter 3). Even though the interaction with the two men on the city center's bench was unplanned, I included this particular research case within this dissertation because the men's perspectives clearly demonstrate that language practices as well as meaning-making practices can often be quite ambiguous and even contradictory. Finally, I included the supermarket in De Donderberg neighborhood, since it is generally believed that such 'diverse' stores are typically not found within the periphery of Limburg but only in the Randstad area of the Netherlands within the cities of Amsterdam, The Hague, Rotterdam, and Utrecht. By including this supermarket in this dissertation, I was able to go beyond the idea that Limburg is a province where linguistic and cultural diversity only include dialect and carnival practices, while at the same time demonstrating that the store is not an exotic place within Limburg but very much embedded in its local context. 
Since 'the ideal ethnographic recipe' is the result of, at times embarrassing, trial and error in a particular fieldwork site, I will describe the ethnographic undertakings for each research case in more detail in the relevant chapters. Generally, though, I made use of the following ethnographic techniques in all of the research locations: hanging around, doing observant participation rather than participant observation, engaging in informal chatting and conversations, and conducting more formal interviews. I recorded my experiences, observations, and conversations by taking field notes that described occurrences, activities, language practices, conversations and self-reflections. Moreover, I made audio and, to a lesser extent, video recordings to capture the actual language practices of the people around me. These ethnographic techniques resulted in considerable sets of different types of data per research location, including field notes, audio and video recordings, recording and interview transcripts, and photographs:

\begin{tabular}{|c|c|}
\hline $\begin{array}{l}\text { Period of fieldwork } \\
\text { at De Katers carnival } \\
\text { association }\end{array}$ & $\begin{array}{l}4 \text { months in total; from November } 2012 \text { until March } 2013 \text { on weekends and } \\
\text { during the three days of carnival }\end{array}$ \\
\hline Events & 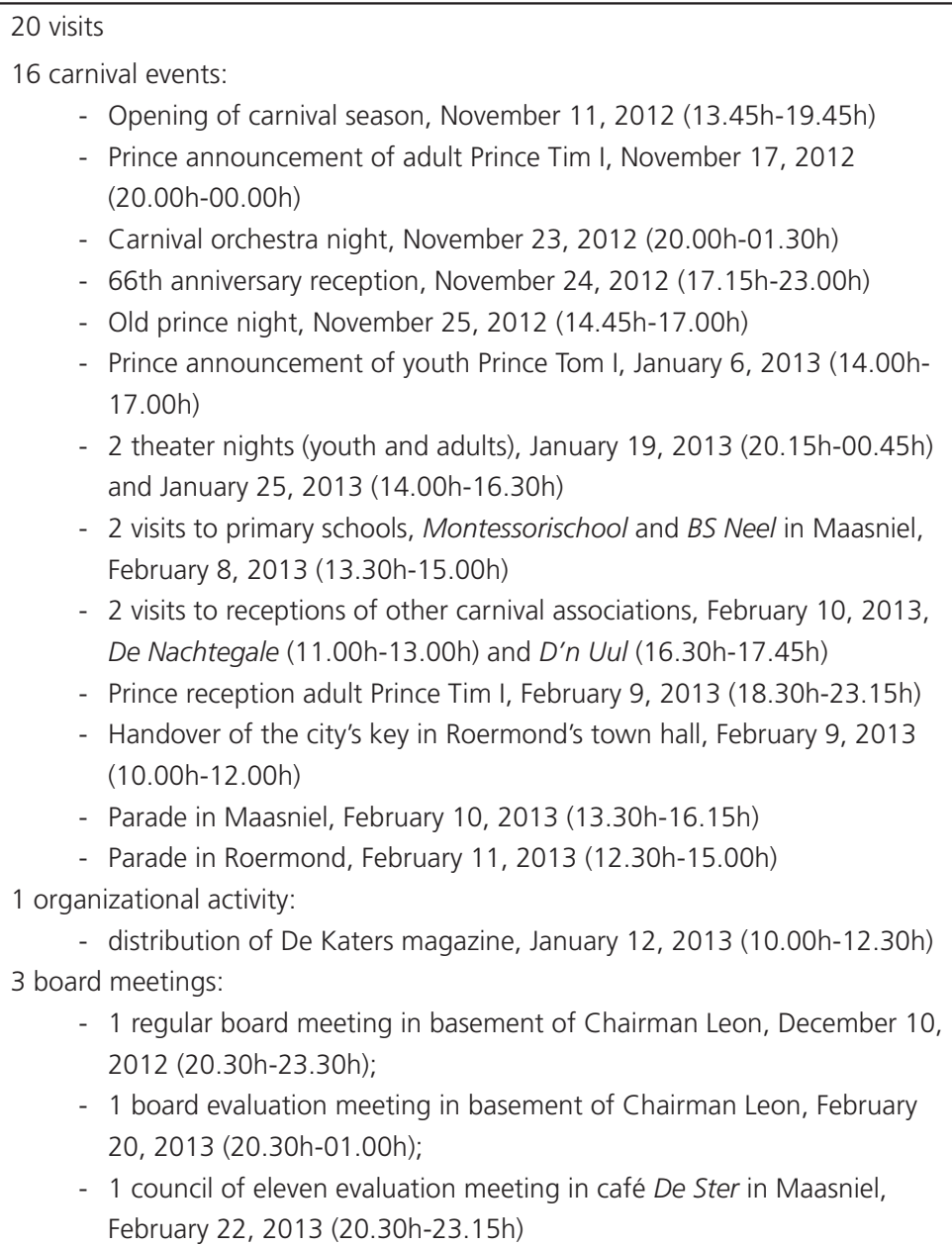 \\
\hline
\end{tabular}




\begin{tabular}{|c|c|}
\hline Interviews & $\begin{aligned} & 7 \text { interviews: } \\
&-\quad 1 \text { exploratory interview with orchestra member Jos at his house, July 2, } \\
& 2012 \text { (20.00h-21.30h); } \\
&- 1 \text { exploratory interview with Chairman Leon and his advisor at the } \\
& \text { chairman's house, October 1, } 2012(10.30 \mathrm{~h}-12.00 \mathrm{~h}) ; \\
&- 1 \text { interview with Monarch Eric in his office, November 7, } 2014 \text { (15.00h- } \\
&16.15 \mathrm{~h}) ; \\
&- 1 \text { interview with orchestra member Wim at his house, March 15, } 2013 \\
&(13.00 \mathrm{~h}-14.30 \mathrm{~h}) ; \\
&- 2 \text { interviews with council members Marcel at his house, March 15, } \\
& 2013 \text { (17.00h-18.00h) and Frank at his house, January 2, } 2014 \\
&(10.30 \mathrm{~h}-12.00 \mathrm{~h}) ; \\
&- 1 \text { interview with De Katers member Jos in a city center café in Roer- } \\
& \text { mond, August 7, } 2014 \text { (15.00h-16.30h) }\end{aligned}$ \\
\hline Field notes & 55 pages \\
\hline Audio recordings & 44 hours, recorded with a handheld recorder (Marantz Professional PMD620) \\
\hline Transcription & 16 pages, including transcriptions by volunteers \\
\hline E-mails & $\begin{array}{l}71 \text { e-mails mainly to Chairman Leon, council member Frank, secretary Maurice, } \\
\text { orchestra member Jos, and Monarch Eric; all e-mails written in dialect }\end{array}$ \\
\hline Visual material & $\begin{array}{l}346 \text { photographs and } 30 \text { videos, made with a digital photo camera (Canon } \\
\text { Digital IXUS } 90 \text { IS, Nikon D3200, and Apple iPhone 7) } \\
3 \text { KlassjeNeel carnival magazines (hard-copies) } \\
1 \text { anniversary 'medal' } \\
2 \text { remembrances of Prince Tim I (a brooch with lights and a flashlight) } \\
\text { Various folders and leaflet }\end{array}$ \\
\hline
\end{tabular}

Figure 2.1: Dataset of carnival celebration practices at De Katers carnival association in Maasniel (see Chapters 3,4 , and 5)

\begin{tabular}{|ll|}
\hline $\begin{array}{l}\text { Fieldwork encounter } \\
\text { with two men on a } \\
\text { bench }\end{array}$ & While hanging around in the city center of Roermond on July 3, 2012 \\
\hline \hline Field notes & 1 page \\
Audio recording & 27 minutes recorded with a handheld recorder (Roland Edirol R09) \\
Transcription & 12 pages \\
\hline
\end{tabular}

Figure 2.2: Dataset of chitchatting with two men on a city center bench in Roermond (see Chapter 6) 


\begin{tabular}{|c|c|}
\hline $\begin{array}{l}\text { Period of fieldwork at } \\
\text { Dost Market super- } \\
\text { market }\end{array}$ & 9 months; from June 2012 until March 2013 \\
\hline Visits & 33 visits, each lasting for approximately 3 to 4 hours \\
\hline Tasks & $\begin{array}{l}\text { - cleaning } \\
\text { - sweeping } \\
\text { - packing customers' groceries } \\
\text { - stocking and aligning shelves } \\
\text { - helping customers } \\
\text { - checking delivery orders (only at the end of fieldwork) } \\
\text { - helping in the butchery (only at the end of fieldwork) }\end{array}$ \\
\hline Interviews & $\begin{array}{l}2 \text { interviews with co-owner Seyit, February 7, } 2014 \text { (16.45h-17.45h) and May } \\
5,2015(12.00 \mathrm{~h}-13.00 \mathrm{~h})\end{array}$ \\
\hline Field notes & 50 pages \\
\hline Audio recordings & $\begin{array}{l}74 \text { hours from October 2, } 2012 \text { onwards, recorded with an MP3 player with } \\
\text { record function (SanDisk SDMX18-008G-E46K Sansa Clip+), attached to my } \\
\text { own clothing }\end{array}$ \\
\hline Transcription & $\begin{array}{l}109 \text { pages, including transcriptions by volunteers and interns of Meertens } \\
\text { Institute/KNAW }\end{array}$ \\
\hline Visual material & $\begin{array}{l}1 \text { advertising flyer } \\
1 \text { interview in local newspaper with owners } \\
14 \text { photographs, made with smartphone camera function (Apple IPhone 5) }\end{array}$ \\
\hline
\end{tabular}

Figure 2.3: Dataset of grocery practices at the Dost Market supermarket (see Chapters 7, 8, and 9)

Obviously, it was not possible to transcribe the many hours and pages of data gathered at the carnival association and the supermarket, although I included most of the recordings of the encounter with the two men on the city center's bench in Roermond in my analysis. Since this research was inspired by grounded theory, the first phase of the analytical process already started during or right after fieldwork events. In field notes, I wrote down what happened during a particular fieldwork visit (with an estimate of the time it occurred) and what events or conversations would be interesting to take into account in full detail. Between fieldwork visits I thematically labeled or coded particular events or utterances, which started off the interpretive process to see certain connections or correlations and to relate to sensitizing concepts. I did not use any qualitative analysis software for this, but did so by hand in field notes or talked to myself in a separate recording file during rides home, both of which I then wrote out in Microsoft Word. My empirical data eventually drew my attention to this research's sensitizing concepts (center-periphery dynamics, place-making processes, and politics of (un)belonging) while further developing these concepts and coining new concepts (foreignness) to describe the social realities I encountered in the field.

After the data was gathered during fieldwork, I had to select what empirical material to use and further analyze in my dissertation based on my pre-selections, labels, codes, and the sensitizing concepts I had already come up with. I orthographically wrote out or 
transcribed (parts of) the corresponding audio files. Only when it was linguistically relevant did I transcribe parts of speech in the International Phonetic Alphabet (IPA). Moreover, I used transcription guidelines from Conversation Analysis to include paralinguistic aspects, such as pauses, repairs, tempo, and gaze.

This chapter, in which I will elaborate further on the above-described fieldwork methods, is organized as follows. Section 1 further explains the value of ethnographic methods to give insight into and interpret people's language and meaning-making practices. In Section 2, I discuss the ethnographic techniques used within the three research locations. Section 3 further explicates how I went about selecting, orthographically transcribing, and analyzing the different types of qualitative data. I conclude this chapter with ethical considerations in Section 4.

\subsection{The importance of grounded ethnography}

\section{Ethnography as a way of seeing}

Ethnographic methods were originally recognized as the main methodology of anthropologists, though researchers from other disciplines (such as sociolinguistics, media studies, and science and technologies studies) increasingly conduct ethnographic research as well in order to examine daily practices and local meaning making. ${ }^{8}$ In fact, for this research, I gained insights from linguistic anthropologists who combined ethnographic methods with linguistic analysis. Hymes, for example, called for the ethnography of speaking (1964: 2-3): an ethnography that "investigates directly the use of language in contexts of situation." Studying language practices in contexts of usage allowed me to collect empirical qualitative data that provided insight into my research question of how people give meaning to the everyday places they engage in through their language practices with others in situated interactions. For this dissertation I carried out ethnographic fieldwork within three research locations in order to examine the language and meaning-making practices involved in them. It is difficult to pinpoint exact tools of ethnographic research, since:

Ethnography is not a particular method of data collection but a style of research that is distinguished by its objectives, which are to understand the social meanings and activities of people in a given 'field' or setting, and an approach, which involves close association with, and often participation in, this setting (Brewer 2000: 59).

Brewer states that ethnography is more a style than merely a method of data collection. My own style of doing ethnography obviously differs from the styles of other ethnographers and, more important, changes according to the fieldwork setting in which I

\footnotetext{
${ }^{8}$ This was also evident from the popularity of and interest in the Ethnography Group that Dr. Anna Harris and I set up in 2013 at the Faculty of Arts and Social Sciences of Maastricht University to discuss ethnography-related topics and best practices regarding, among others, ethics, setting up of fieldwork, field notes, and fieldwork relations.
} 
find myself. The people and practices within the three research locations each required a different ethnographic style: a more informal and inquiring style during the carnival celebrations in Maasniel, a more formal and polite style while chitchatting with the (elderly) men in the city center, and a more informal and hardworking style in the supermarket in De Donderberg neighborhood. Wolcott (1999) distinguishes between 'looking,' as merely observing particular situations, and 'seeing,' as observing and interpreting situations and he argues that ethnography is a 'way of seeing.' Ethnography for me is as much a way of seeing as it is a way of living that allows for openness to the world around me and enables me to critically observe, interpret, and reconsider taken-for-granted aspects in a particular place. It was through ethnography that I became conscious of my environment and that I discovered opportunities during fieldwork. This ethnographic consciousness resulted in my eavesdropping on the man on the train (see Chapter 1) and on the men sitting on the city center bench, and in the realization that the carnival association in Maasniel and the supermarket at De Donderberg could both be potential fieldwork sites. Moreover, ethnographic methods allowed for a certain degree of reflexivity on my own embodiment and behavior, thus adding an additional layer to the analysis of ethnographic material (see Section 2.2).

\section{Interpreting meaning-making and language practices through ethnography}

I deem ethnographic consciousness and ethnographic methods indispensable in addressing how people in my three research locations engaged in meaning-making through language practices for two reasons.

First, through ethnographic methods I was able to learn within the research locations how people engaged with and gave meaning to the world around them, thus allowing for the study of local meaning-making practices. Interpretative anthropologists believe that "man [sic, LT] is an animal in webs of significance he himself has spun" (Geertz 1973: 5, my comment). These webs are 'cultures' and analysis needs not to be "an experimental science in search of law but an interpretive one in search of meaning" (ibid). 'Cultures' are, in other words, meaningful texts constructed by people that need to be deciphered by ethnographers by means of ethnography. Having its roots in interpretative anthropology, ethnography enabled me to record, grasp, and, to a certain extent, understand the everyday language and meaning-making practices of people in the carnival celebrations of Maasniel, of people chitchatting in the city center, and of people working or doing their grocery shopping at a supermarket in De Donderberg neighborhood. Instead of aiming at objectively representing 'a culture' or 'a language,' I rather aimed to write an ethnography that represents incomplete images of the world and the practices within it as they are interpreted by the ethnographer (cf. Clifford in Barrett 2002), yet gives valuable insights in broader patterns of behavior. From a methodological viewpoint, the ethnographic accounts in this dissertation, from the perspective of the ethnographer, aim to give an interpretation of people's language and cultural practices - rather than of 'cultures' and 'languages' as a whole - and the ways they give meaning to the world around them. Ethnographic methods therefore suit this dissertation's perspective on language as a resource and meaning-making practices.

These interpretations need to be based on specific grounds. The ethnographer needs to make interpretations plausible and convincing through generalization within or 'thick description' of small cases instead of generalizing across cases (Geertz 1973: 26-27). 
In order to understand the social meanings that lie behind particular practices or acts, the ethnographer needs to know about the context in which practices or acts are embedded. For this, thick description is needed to argue why an act or practice is interpreted in a particular way and how and why the ethnographer understands it as such. Geertz's (1973) famous example is a wink, which can be a person's twitch, a hint of flirtation, a joke, or simply some dust in the eye. Dependent on the context of usage, the movement of the eyelid can be interpreted in different ways. Thick description is needed to argue why a wink is interpreted in a particular way and how and why the ethnographer understands this wink to be exactly that. As a result, the aim of ethnography is not to provide large generalizations that enable predictions, but "to draw large conclusions from small, but very densely textured facts; to support broad assertions about the role of culture in the construction of collective life by engaging them exactly with complex specifics" (Geertz 1973: 28). This is why I will, in the coming chapters, first thickly describe the fieldwork locations before analyzing specific interactions, since thick description enables me to eventually provide insights into how people give meaning to the place they live in through their language practices with others.

Second, by closely associating with and participating in people's activities and practices, I was able to record people's actual language practices instead of their reported use of linguistic forms or 'languages.' A focus on linguistic forms would have demanded more Labovian methods (Cornips and Gregersen 2016; Labov 1991), such as the sociolinguistic interview in which people are asked to read aloud word lists and engage in socalled 'casual speech' that might nevertheless be influenced by the interviewer's presence. Without pretending to record 'natural' speech (there is no such thing), the longer term presence of ethnographers enables the building of trust with research participants and thus gaining insight into what people actually say and do rather than what they say they do. This research stands in line with the work of Dell Hymes (1963), John Gumperz (1992), and Alessandro Duranti (1997a), who incorporated the study of language in anthropological research where, in contrast to traditional sociolinguistics, the focus is on "producing ethnographically grounded accounts of linguistic structures as used by real people in real time and real space" (Duranti 1997a: 3, my italics). Furthermore, looking at language practices through an anthropological lens provides insights into how linguistic forms mediate "the ideational and material aspects of human existence and, hence, in bringing about particular ways of being-in-the-world" (ibid: 4-5). By using ethnographic methods, I aimed, indeed, to give bottom-up accounts of how people use linguistic forms and how they produce meanings and negotiate diverse ways of being-in-the-world in doing so. Building on Hymes, Gumperz, and Duranti, both sociolinguists as well as linguistic anthropologists, increasingly incorporated ethnographic methods into their research to study meaning-making through language, some of which have specifically focused on the linguistic construction of identifications of 'us' and 'them' (key publications being: Bucholtz 1999; Eckert 2000; Jaspers 2005; Johnstone 2013b; Gal and Irvine 1995; Madsen 2015; Ochs 1993; Quist 2010; Sweetland 2002).

\section{A grounded focus on locations}

This research combined ethnographic methods with insights taken from grounded theory (see Chapter 1). This combination of methodological and theoretical perspectives connected well to the focus on real language practices in real time and real space (cf. Duranti 
1997a) in that it enabled the study of language practices in an open and dynamic way instead of approaching the field with pre-set categories of particular 'groups,' 'languages,' and 'cultures.' Within the context of this research, this implied that empirical data drew my attention to the earlier clarified sensitizing concepts (i.e., center-periphery dynamics, place-making processes, and politics of (un)belonging) while further developing these concepts and coining new concepts (i.e., foreignness) to describe the social realities I encountered in the field (cf. Becker 1998; Blok 1976; Blumer 1954; Charmaz 2003; Corbin and Strauss 1990).

To allow for a grounded and bottom-up perspective, it was crucial to let go of pre-set categories ('groups,' 'languages,' 'cultures') and to approach language and meaning-making practices as they are: open and dynamic. To that end, this research explicitly used locations as its jumping-off point. This decision was theoretically inspired, but obviously had methodological implications, since it required a focus on locations instead of on categories of people ('the Limburgers') or language blocks ('the Limburgian dialect'). In doing so, I built on linguistic anthropological insights that regard speaking as a social, cultural, political, and economic practice that can be studied by using an ethnographic methodology that "investigates directly the use of language in contexts of situation so as to discern patterns (...) which escape separate studies of grammar, of personality, of religion, of kinship and the like" (Hymes 1964: 2-3, my italics). Hymes thus encourages the study of language within the contexts of situations. This is why this ethnographic research explicitly focused on locations, since it is "only through rich ethnographic studies that space and place - and what we make of them in human relations can be examined" (Olwig and Hastrup 1997: 7-8).

In order to avoid groupism - "the tendency to take discrete, sharply differentiated, internally homogeneous, and externally bounded groups as basic constituents of social life, chief protagonists of social conflicts, and fundamental units of social analysis" (Brubaker 2002: 164) - I deliberately examined how people within locations gave meaning to the place itself and to the practices in which they engaged. In this way, I was able to let go of essentialist and groupist categories and instead to examine how people created ideas about commonalities and connectedness within particular places (cf. Brubaker 2002). A focus on locations thus allowed me to move away from bounded research categories and labels that are used for a 'type' of research participants and 'their' language. I must admit that it took quite some time until I myself could embrace this way of looking at the world. At the beginning of my fieldwork, I regarded the members of the carnival association of Maasniel and the two men on the bench in the city center as 'native Dutch,' while labeling the supermarket staff as having a post-migrant background - whatever that might be.

Such categorizations did not illuminate what was important for people and how they saw themselves at a particular moment and in a particular place. It was thus a struggle to break with such essentialist categorizations myself and instead to examine meaning-making and language practices in which people inhabiting and living in certain locations engage.

A focus on locations does not imply that I regarded a location as the main predictor for language practices. On the contrary, instead of labeling research participants as, for example, speakers of 'Limburgian dialects' or 'Dutch' just because they lived in Limburg and the Netherlands, I examined what practices and beliefs were salient for the people living, interacting, talking, and doing things in particular locations - that are embedded in larger contexts - without assuming they would use particular linguistic forms. It is thus by focusing on the placed (language) practices that meaning-making practices of people can 
be studied. Therefore, I examined the spatial repertoires (cf. Pennycook and Otsuji 2014) that included language practices, ideological categories, and labels that were salient to and used by the people in particular locations in order to make sense of the world around them and the people with whom they interacted. As part of these spatial repertoires, I included the material display of linguistic forms in or the linguistic landscape (Landry and Bourhis 1997) of the research locations by looking at advertisements and billboards to clarify how linguistic forms were attached to places, thus shaping place-making processes.

\subsection{Ethnographic techniques and reflexivity}

\section{Ethnographic techniques}

For this dissertation, I made use of specific techniques in order to collect data: hanging around, observant participation rather than participant observation, building trust, chatting and conducting interviews, field notes and audio recordings. For the most part I relied on the excellent and hands-on guide for fieldworkers written by DeWalt and DeWalt (2002).

Most fieldwork projects start with a phase of hanging around. Hanging around indicates an exploratory phase in which the ethnographer is on the look-out for interesting locations, people, and events. At the same time, the ethnographer takes in all possible information available about the fieldwork site, from news and events to small interactions of people in streets, public transport, and shops. This phase started in June 2011, as soon as I knew I was going to pursue my Ph.D. research within Limburg. I scouted for interesting news items about the province and read books about Limburg's history. When I started to work at Maastricht University, in September 2011, my initial exploratory fieldwork included walking around Maastricht, describing linguistic landscapes (cf. Landry and Bourhis 1997), and having informal chats with people on the street and in shops. After making the decision to carry out my fieldwork in Roermond, I started to physically hang out around Roermond from November 2011 onwards. I visited different community centers to participate in and observe social and cultural events. Some of these undertakings were successful: I remained involved within several events, such as the cooking club, Grenzeloos Genieten (Borderless Delight), led by Henni and Marleen; I visited, together with Marleen, the monthly women's breakfasts at the El-Fatih mosque. Others were less successful: I started a bus-ride experiment only to find out that buses are too noisy for comprehensive recordings of interactions taking place within the bus; I observed a group of young men performing brass music, which nearly destroyed my recorder device and eardrums due to the loud drumming. In July 2012 I realized that I mostly hung around in the neighborhoods of Roermond. For this reason, I decided to hang around in the city center, since the summer makes the city center a popular attraction for inhabitants as well as daytrippers and tourists because of some of the summer events taking place there. While hanging around in the city center, I visited shops and sat on benches on plazas and in shopping streets, while trying to talk to people or simply observing and listening. At the end of July, I assisted my father at his stall (selling antique and present-day comic books, coins, and stamps) during the two-day flea market, Sjommelmert. During these two days I was able to observe and participate in many conversations with other stall owners, customers, and passers-by.

While 'hanging around' I felt uneasy in the beginning. The reason was that I made audio recordings and took photographs without people's being aware of this. Even though 
taking photographs in the public sphere is legally allowed, my discomfort arose mainly about the audio recordings and the idea that I was some kind of spy. With the exception of the encounter with the two men on the bench, who granted permission to make audio recordings, I decided not to work with the data gathered during the hanging-out phase (see Section 2.4 for more ethical considerations). Nevertheless, the impressions, experiences, and observations gained from hanging around added to a more complete understanding of the city in all its facets, an understanding that added to my sense of Roermond as an ethnographic site (cf. Pink 2008, 2009).

After the summer of 2012, the hanging-around phase came to an end, and I started to divide my time among a stable number of fieldwork sites: the supermarket, the carnival association, the cooking club Grenzeloos Genieten (Borderless Delight) in the De Donderberg neighborhood, weekly dinners with Mar-Li (see Chapter 1) and her friends, and the monthly women's breakfasts at the El-Fatih mosque. It was at these sites that I could engage in participant observation, which is "a way to collect data in naturalistic settings by ethnographers who observe and/or take part in the common and uncommon activities of the people being studied" (DeWalt and DeWalt 2002: 2). In other words, participant observation is an emic or bottom-up research technique that enables the ethnographer to gain an insider's perspective. My fieldwork activities in Roermond put an emphasis on the participant part of 'participant observation,' since it was mainly through participation in the practices of people inhabiting a particular location that I gained an understanding of the most fundamental processes of social life (DeWalt and DeWalt 2002: 3). Through participation I could observe and take into account the particularities of people living and unfolding their lives in a variety of locations. According to Moeran (2007), the term 'observant participation' more accurately covers the actual activities of an ethnographer, since participation is vital in fieldwork. This switch from participant observation to observant participation allows ethnographers to:

see beyond the social front that informants present to strangers in their everyday lives, to know that there is a difference between what Erving Goffman refers to as 'front stage' and 'back stage' behaviour, and to have ready access to that back stage (Moeran 2007: 14).

My own observant participation enabled me to see and experience beyond the 'front stages' and to gain access, to a certain extent, to the 'back stages' of my fieldwork locations. Sometimes this 'back stage' was quite literal, for example, being allowed to go to board meetings of the carnival association, which were held in the chairman's basement, or feeling comfortable enough to enter the storage of the supermarket, even when the owners were talking business in there. Even though the encounter with the men sitting on the bench in the city center of Roermond (Chapter 6) was part of the hanging around phase of my ethnographic fieldwork, I would regard myself as an observant participant in that situation who was, just like the two men, enjoying the sun on a city center square while chitchatting with passers-by. In the locations where I conducted longer-term ethnographic fieldwork - the carnival association (Chapter 3, 4, and 5) and the supermarket (Chapter 7, 8, and 9) - I tried to take part in as many activities as possible while also being allowed to join more 'back stage' events after some time. In that sense, the idea of observant participation is similar to Ingold's argument that anthropologists do research with research participants instead of about them: 
What truly distinguishes anthropology, I believe, is that it is not a study of at all, but a study with. Anthropologists work and study with people. Immersed with them in an environment of joint activity, they learn to see things (or hear them, or touch them) in the ways their teachers and companions do. An education in anthropology, therefore, does more than furnish us with knowledge about the world - about people and their societies. It rather educates our perception of the world, and opens our eyes and minds to other possibilities of being (Ingold 2008: 82; original italics).

As Ingold argues, learning from and being taught by my research participants how to do or say things was essential for my fieldwork. It is this perception that re-emphasizes that ethnography is not only a way of seeing (cf. Wolcott 1999) but also a way of living that allows for openness to the people around us and an eagerness to learn how they do and see particular things in their lives. Although I was familiar to some extent with the fieldwork sites of the carnival association and the supermarket beforehand (due to being an enthusiastic carnival celebrator myself and having worked at a supermarket as a student), during fieldwork research participants enjoyed teaching me about specific routines and particularities of their site. When telling people at the carnival association that celebrating carnival within an association was new to me, they usually felt a responsibility to fill me in on their own personal experiences of the numerous events, specific rituals, and history of the association. The same held true for the supermarket (see Chapter 7, 8, and 9). As a student, I had worked at a large chain supermarket where I learned how to deal with products and customers. Yet, the smaller scale of the supermarket was not comparable with the large store I worked in as a student. Therefore, the owners regularly taught me how exactly to do things and how to, for instance, deal with particular customers. Also, the staff enjoyed teaching me how to say things in other languages or making fun of me with words I did not understand. This illustrates how doing fieldwork is rather a study with than a study of people (cf. Ingold 2008).

In both fieldwork sites, I used the skill of an observant participant to remain a bit naïve and ignorant in order to obtain information from my research participants, even when I was not 'brand new' to the place anymore (cf. Bernard 1995). By expressing my misunderstanding, I was able to avoid 'going native' and to re-emphasize, even after a while, my outsiderness. This facilitated maintaining some distance from the fieldwork sites and analyzing the research setting, the people involved, their relations, and practices from a somewhat etic perspective. I deliberately write 'a somewhat etic perspective,' because I do not believe that, after a period of fieldwork, you can ever be a complete outsider again. Yet, as a researcher, it is important to be able to switch back and forth between the emic role of a fieldworker immersed in the fieldwork site and the etic role of an analyst looking at the data from a higher analytical level where one is able to draw comparisons between fieldwork sites with the help of sensitizing concepts.

Building trust is another key technique of ethnographers in order to be able to collect data and to be allowed to experience the 'back-stage' behavior (cf. Moeran 2007) of research participants. In order for research participants to open up to you by sharing their insights and thoughts, 'rapport' is required that:

is achieved when the participants come to share the same goals, at least to some extent (...) and when the researcher approaches the interaction in a respectful and 
thoughtful way that allows the informant to tell his or her story. It is about the need to develop a situation of trust and cooperation (DeWalt and DeWalt 2002: 40).

This development of rapport takes time. Building rapport was challenging in the carnival association due to that year's short carnival season from November until the beginning of February. By attending as many events as possible (see Figure 2.1 above) and by expressing my willingness to understand the events and, more important, to participate in and enjoy them, I was increasingly trusted by most members. In the case of the men on the bench who, within a short time span, opened up to me to share their stories and experiences in Limburg, using the word 'trust' might be an exaggeration. Yet, even during such a brief encounter, it was necessary to come across like a trustworthy person. I did so by asking open questions and listening attentively to their accounts. At the supermarket, a few afternoons of hard work were necessary in which I was not so much doing research in the sense of collecting data as, rather, building rapport by stocking shelves, cleaning, and doing the little tasks no one really liked. This dispelled most of their caution, since they saw that I was willing to work and was not just 'using' them for research. They seemed to take my audio recordings and note taking for granted quite quickly, since my presence also meant extra help for them. Moreover, the fact that I grew up in the neighborhood where the supermarket was located and that some of the staff members knew my family enhanced my contact with them. I elaborate on my first contact within both long-term fieldwork sites later (see Chapters 3 and 7).

In my view, ethnographic research and building trust really benefit from the ethnographer's willingness to open up to participants herself and to also reveal some personal information. One cannot expect people to open up, when the ethnographer is too reserved herself. Therefore, I shared personal stories and views in order to gain trust and to bond with my research participants. Of course, I am also human, with particular preferences, and mainly opened up to the people I felt connected to. For example, I stayed in touch with some members of the carnival association via e-mail to receive updates about their and the association's well-being. During fieldwork in the supermarket, I befriended the Facebook page of the store to keep me updated (although it was not a very active page at that time). Moreover, I added one owner to the WhatsApp instant messaging application to check with him when I could come to 'work.' After fieldwork, I befriended both owners of the supermarket on Facebook, which was a good way of staying in touch with them in case I wanted to check up on small things or arrange an interview.

Chatting and conducting interviews make up an important part of ethnographic research and observant participation. Although I obtained much valuable data from just 'being there' and learning how things go around there (DeWalt and DeWalt 2002), my audio recordings, informal conversations, and interviews enriched my understanding of fieldwork sites substantially. Interviews were held with research participants from the carnival association and the supermarket after the period of fieldwork ended. I used semi-structured topic interviews that included "an interview guide with a list of questions and prompts in order to cover all topics in all interviews in more or less the same way" (DeWalt \& DeWalt 2002: 122). Observant participation paved the way in conducting interviews because I was able to grasp the underlying stories of my research participants more thoroughly than when I had not previously participated in their carnival celebration practices or supermarket practices. 
The use of these different research tools that make up ethnographic fieldwork resulted in recording different types of data: field notes, audio recordings, transcripts, photographs, and videos (see Figures 2.1 to 2.3). Some explanation is appropriate about how I actually recorded and gathered these data in the three fieldwork locations. At the carnival events, I felt comfortable making audio and video recordings and taking photographs immediately, since many attendees were accustomed to the use of equipment or used equipment themselves during the events. For the audio recordings I used a handheld recorder (Marantz Professional PMD620), and for the video recordings I used a digital photo camera (Canon Digital IXUS 90 IS). Taking notes was, however, not a very common thing to do during carnival celebrations. In order not to stand out too much or give people the uncomfortable feeling of being watched and written about, I often went to the bathroom to quickly scribble down interesting and important observations or things I heard..$^{9}$ It was important to do this, since the carnival events were usually loud and noisy, so that recordings were not as clear as I could have wished. By taking as many notes as possible, taking photographs, and making audio and video recordings, I was able to avoid missing out on too many occurrences, activities, and talks and, also, to capture gestures, gazes, bodily expressions, and decorations in the carnival celebration practices.

During the encounter with the men on the bench, I asked permission to turn on the audio recorder (Roland Edirol R09 handheld recorder) immediately after I introduced myself and my research. This allowed me to capture the full discussion of the men about feeling at home, or not, in Limburg and Roermond and their remarks towards me about my own belonging. Moreover, the recordings enabled me to closely analyze their use of linguistic forms. After the encounter, I immediately took notes in my notebook about how the men positioned themselves towards each other and me and other (personal) characteristics of the men.

Unlike the carnival association, technical equipment is not really commonly used in supermarkets, which is why I decided not to switch on the audio recorder immediately upon arrival and introduction into the shop but to first build rapport with both staff and (frequent) customers before doing so. After two months of working in the shop, I asked permission of staff members to make audio recordings, which they granted me. To prevent the recorder from hampering me in performing my supermarket tasks, I used an MP3player (the SanDisk SDMX18-008G-E46K Sansa Clip+) with audio recording function that I could clip onto my own clothing. Moreover, due to the oddness of using technical equipment (other than smartphones, labelers, and cash desks) within the supermarket, I deliberately wanted to make use of a smaller audio recorder than a larger handheld device in order to avoid attracting too much attention with the device. Unlike the carnival association, it is not as strange to take notes in a supermarket, since they could well be assumed to be order lists or other shop-related writings. However, taking notes and carrying along a notebook were a bit difficult to combine with the tasks of cleaning, helping customers, and stocking shelves. Again, I found myself going to the bathroom and the storage a lot to quickly scribble down observations and conversations.

\footnotetext{
${ }^{9}$ Bathrooms are little havens for ethnographers. My dear colleague Rafael Bienia and I shared many stories about feigning weak bladders, or worse, in fieldwork situations in order to write up observations.
} 


\section{Ethnographic reflexivity}

The ethnographer's body could be seen as his or her own research instrument. Even when using notebooks, audio recorders, or photo cameras, the ethnographer is the one who selects or deselects what is interesting, interprets the data collected, and gives meaning to the data through the connection to analytical concepts. More important, the ethnographer always influences the location in some way or another: simply by being there, the setting and the practices within that location change due to the presence of the ethnographer. This does not lower the quality of fieldwork; on the contrary, it offers an additional analytical layer to research wherein the ethnographer should be reflexive on how his or her presence influences the location. It was not until the 1970s that ideas about reflexivity became positively evaluated as being part of ethnographic research (Davies 2008). Hammersley and Atkinson (1995: 16) argue that reflexivity on an ethnographer's own emplacement informs about the location one studies. Rosaldo adds to this that reflexive ethnography enhances ethnographic understanding, which is to say that personal involvement is acknowledged and reported upon (Rosaldo 1993).

In order to incorporate this reflexivity into my research, I follow Pink (2008) in regarding ethnographic methods as the perfect way to study people's place-making practices, while, at the same time, acknowledging that ethnography itself is a place-making process on the ethnographer's part, in which he or she is involved in the constitution of that location as well (Pink 2008: 179).

Chapter 1 already demonstrated how, throughout my life, my appearance has been interpreted by others and that I was confronted with my own emplacement, embodiment, and engagement in the three research cases of this book: at the carnival association, board members did not respond to me in dialect; the men on the bench regarded me as being an outsider in Limburg; and, similarly, the supermarket's butcher classified me as being a 'foreigner.' For ethnographic work, it is essential to make use of these confrontations in order to learn about research locations, as my professors taught me during my bachelor's degree studies:

The anthropologist should not try to become a member of the society he or she is studying but has to systematically exploit the fact that he or she is not a member starting from the difference with his or her own cultural rules to find out what the rules of others look like (Mommersteeg and Steenbeek 2008). ${ }^{10}$

In order to systematically exploit, as Mommersteeg and Steenbeek put it, my perceived otherness, my intent was to engage in the kind of sensory ethnography that explicitly asks for reflexivity on embodied ethnographic experiences (Pink 2009: 25). Thus, while I was interested in the ways that people in Roermond gave meaning to and emplaced themselves in places, my intent was also to be explicitly reflexive on my own emplacement and embodiment in specific research locations in order to learn more about a fieldwork location and the views of people met there (cf. DeWalt and DeWalt 2002; Pink 2009). Some ques-

\footnotetext{
10 Since the quote was embedded in a bachelor's program of Cultural Anthropology, it refers to the ethnographer as 'the anthropologist.' An ethnographer is, however, not always an anthropologist. Yet, an anthropologist is often an ethnographer.
} 
tions I will address in chapters to follow are: did I feel in or out of place? How did I influence the place-making processes and practices in a particular location? How did people in a particular location respond to me and my embodied appearance?

\subsection{The selection, orthographic transcription, and analysis of empirical data}

During the fieldwork period in the carnival association and the supermarket, the pile of data that needed to be transcribed and analyzed grew rapidly. After visits to the fieldwork sites, I immediately worked up field notes on the computer and made copies of my audio recordings. In field notes, I described what had happened during a day or event and what might possibly be interesting passages to further analyze later. As explained in Chapter 1, my research drew on insights from grounded theory in working with sensitizing concepts that obtain their significance in dialogue with empirical data from the field (cf. Becker 1998; Blok 1976; Blumer 1954; Charmaz 2003; Corbin and Strauss 1990). In this way, theory is prevented from being divorced from the everyday practices of people (Becker 1998: 4). Data collection and analysis are thus interwoven, so that the field puts forward ideas, assumptions, and sensitizing concepts that can be further investigated within the field. These sensitizing concepts helped me to alternate between an emic perspective (a view from within the research location and participants) and an etic perspective (from the observer's point of view) on the empirical data.

When my fieldwork was finished, the second phase of the analytical process could start, in which I orthographically transcribed interesting happenings, conversations, or utterances. In this phase, I looked at different units of analysis. The first unit consisted of content analysis: what was said, what was the topic? The second part, on the other hand, focused on how things were said. In this, I did not only consider linguistic forms, such as phonological, morphological and lexical forms, but also more paralinguistic forms that are important in conversation analysis, such as interlocutors, tone, tempo, volume, and gaze (Ten Have 2007 [1999]). Working from a perspective that considers language as an integral part of culture and vice versa, the analysis can best be described as a hermeneutic circle that examines linguistic form as well as cultural meaning-making, thereby looking at gestures, materials, and body language (cf. Cornips et al. 2012). This complex analysis thus took into account the linguistic forms, the interpretation of people's meaning-making, and the relations to sensitizing concepts (cf. Johnstone 2000).

For the transcription of the data, I used the Express Scribe software program (developed by NCH Software). As mentioned above, considering the many hours of recordings I gathered in both the supermarket and the carnival association, only those parts that I deemed interesting were transcribed. As Johnstone notes, "there is no such thing as a completely accurate transcript of speech" (Johnstone 2013a: xviii). Therefore, I devote some space to elucidate how I transcribed linguistic forms that are usually recognized as belonging to dialects spoken in Limburg. Even though there is an officially recognized spelling for dialects in Limburg developed by the dialect organization Veldeke in 2003 (Bakkes et al. 2003), most people in Limburg do not relate to this spelling. Many people in Limburg do not generally think about how to write dialect in text messages or on social media; they do as they like. There is thus a tension between the practices in actual reality and the top-down design of spelling rules. Therefore, I decided not to prefer one over the other and to transcribe in such a way that I adhere to some of the general rules ('ao' 
instead of 'oa') of the Veldeke spelling, but leave out the many diacritics, such as äö as in jäörig (having one's birthday) or ó as in bóks (trousers), which obstruct the readability of the transcripts as a whole (Johnstone 2013a), something Bucholtz (2000) has called an 'eye dialect.' In coming extracts, I will provide the English translations, which are translated rather than glossed, below the original orthographic transcripts. In some cases, an extra line is added to provide comments or additional explanations of the transcription. The transcription conventions are found at the beginning of the book before Chapter 1 .

\subsection{Ethical considerations}

While conducting ethnographic fieldwork, I was highly aware of the ethical implications that my research could have for others. In making ethical decisions, I followed the ethical statement by the American Anthropological Association on professional responsibility (AAA 2012) in which it is stated that ethnographers should: not harm; be open and honest regarding their work; obtain informed consent and necessary permissions; weigh competing ethical obligations due collaborators and affected parties; make their results accessible; protect and preserve records; maintain respectful and ethical professional relationships.

Moreover, I also complied with the Code of Ethics for Research in the Social and Behavioral Sciences Involving Human Participants, as abided by the Faculty of Arts and Social Sciences of Maastricht University (2016). The points on consent and permission of both Codes were most important for me to reflect upon.

In earlier research I was convinced that turning on a recorder would scare away research participants during fieldwork, so I stuck with taking field notes and photographs. Yet, given the fact that this research is interested in people's language practices, audio recordings were essential in order to capture used linguistic forms and to be able to carefully transcribe and analyze them. Audio recordings brought along ethical considerations and dilemmas that were new to me, such as deciding the right moment to switch on the device. I obviously always respected my participants' wishes and never recorded anything against their will. The names given in this dissertation are only real in cases where I obtained explicit permission to use them. For instance, during the relatively short encounter with the two men on the bench I did not get a chance to ask permission, so their names are fictional. At the carnival association and in the supermarket, it was impossible to formally obtain the permission and consent of every person present in that location. In those cases, I always referred to them with a fictional name or with their role ('member of council of eleven' at the carnival association or 'customer' at the supermarket) and, moreover, made sure that they were unrecognizable to fellow colleagues, other research participants, and future readers.

In line with the Principles of Professional Responsibility of the AAA (2012), I always openly informed my research participants that I was conducting research when they inquired about my role in a given research location. However, since many people did not fully understand my position at the university as a Ph.D. candidate, they mostly regarded me as a student or intern. I tried to change this by telling them that I was writing a dissertation, but not everyone seemed to grasp the difference. I therefore informed participants that I would eventually write 'a book' that would be made available for everyone who wants to read it. Besides giving popular lectures, talks, and interviews, (key) research participants will receive a copy of the dissertation. 
Finally, immediately after recording, I safeguarded my data (field notes, photographs, and recordings) by ensuring that it was carefully stored and backed up on the university driver as well as on a personal external hard disk to which only I and my supervisor had access. After fieldwork, I shared audio recordings with volunteers and students who helped with the transcription of data. None of them received any data before signing and agreeing to the rules for transcription guaranteeing the privacy of research participants and researcher; agreeing not to share, publish or expose the research material to (social) media; and agreeing that the materials remained the intellectual property of the researcher and the university, conforming to the Research Data Management Code of Conduct of Maastricht University (2014).

\section{Conclusion}

Ethnography is the most appropriate method to address this dissertation's main question of how people, through their language practices with others, give meaning to the everyday places they inhabit. Ethnographic methods enable the study of daily language and meaning-making practices of people instead of only including reported language use. Moreover, I argued that using locations as a jumping-off point, rather than a focus on categories of people and languages, enhances the grounded study of language and meaningmaking practices. I have described ethnography as a way of seeing and living in which the ethnographer studies with rather than about the research participants to prevent analysis from being far removed from empirical realities (cf. Becker 1998; Brewer 2000; Ingold 2008; Wolcott 1999). Besides different ethnographic techniques (hanging around, observant participation, building trust, chatting and conducting interviews, field notes and audio recordings), I explained my intent, throughout this book, to be explicitly reflexive about my own emplacement and embodiment. My analysis can only benefit from these reflections on how other people relate or respond to my (bodily) presence, thus adding another layer to studying how people give meaning to the places they inhabit and the people they talk to. Moreover, I clarified how I went about selecting, orthographically transcribing, and analyzing the different sorts of qualitative data. I also dedicated some space to explaining how I behaved ethically while conducting ethnographic fieldwork. Every ethnographic fieldwork differs according to context and research location: in the chapters that follow I will describe the specific ethnographic undertakings for each research case as well as reflect on my own emplacement and embodiment in more detail. 


\section{Part I}

Carnival celebration practices at De Katers

in the former village of Maasniel 


\section{Chapter 3}

\section{Entering the field of carnival celebration at De Katers carnival association from Maasniel}

\section{Introduction}

Carnival is a celebratory period that starts every year on November 11 and ends with the three days of carnival prior to the fasting period of Lent. In Limburg, carnival celebration and dialect use play a key role in the production of regional and local identities (Cornips \& De Rooij 2015; Wijers 1995). Carnival in Limburg can be described, in the Bakhtinian sense (1984 [1929]: 122-123), as carnivalesque, since hierarchies between people are suspended, allowing for free and unconventional modes of social interaction and 'carnivalesque mésalliances.' As a focal point for examining how people give meaning to the places they inhabit and the relations they have with other people through language practices, carnival events are exciting occasions, especially within the context of Limburg, a region of the Netherlands that is perceived to be peripheral (see Chapter 1). In so doing, this research supports and adds to the existing strand of anthropological and sociolinguistic research that perceives carnival as a vital domain for examining themes such as identity construction, class, and status. Research has been conducted on carnival celebrations in Europe: Finland (Pietikäinen 2015) and the Netherlands (Cornips et al. 2012; Cornips and De Rooij 2015; Wijers 1995), as well as in Latin America: Brazil (Da Matta 1991; Sheriff 1999), Haiti (Averill 1994), and Trinidad \& Tobago (Fournillier 2014).

One of the reasons I wanted to include carnival celebration practices in Roermond was my memory of how my classmates and I were expected to sing along with dialect songs during carnival celebration in primary school and the First Communion ceremony in the Catholic Church. ${ }^{11}$ I vividly remember the following line from a dialect carnival song by $D e$ Donderböl carnival association, associated with Roermond's De Donderberg neighborhood:

Veer zeen van de Donderböl, net zo good es geer, tralala tralala We are from the Donderböl, just like you, tralala tralala. ${ }^{12}$

What struck me, in hindsight, was that we were all expected to sing along with the dialect song, regardless of whether we were familiar with speaking dialect at all. This suggests a taken-for-granted connection between carnival and the use of linguistic forms that are enregistered as dialect. Moreover, through the song, we learned that we were connected in some way to De Donderböl from De Donderberg, simply by the fact that we attended a school located in the same neighborhood, where most of us also lived. In a way, then, this song helped in some way to construct and reinforce a shared feeling of

\footnotetext{
${ }^{11}$ During the ceremony, the communicants sang Catholic songs that were all translated into dialect.

12 For connoisseurs, this song was sung to the melody of the song De Weerd, which refers to a natural pool close to Roermond. Instead of "veer zeen nao De Weerd gewaes, net zo good es geer" ("we went to De Weerd, just as good as you"), people from De Donderberg and/or associated with De Donderböl usually sing the Donderberg variant.
} 
belonging because of the simple fact that we lived in De Donderberg neighborhood. Having grown up in Limburg and being a carnival celebrator myself, I knew that the ritual of carnival can be quite central in the calendars of many inhabitants in the province either because they want to celebrate it or they want to escape it and plan a holiday to a non-carnival celebrating area. Moreover, carnival celebration in Limburg is regarded as being associated with a strong regionally imagined and felt identity and as a festive period where this identity can be expressed by using local dialects. Due to these associations between Limburg and carnival celebration (see Wijers 1995), I wanted to include carnival in my fieldwork in order to examine if and how this link between the strong regionally felt and imagined identity of Limburg and carnival is reproduced in carnival events through language practices. This helps to answer the research question, from a carnival perspective, of how people give meaning to the places they inhabit during carnival celebration practices.

This chapter provides further reasons why I included carnival celebration practices at the carnival association of De Katers (The Tomcats). Section 3.1 will provide some background about the celebration of carnival in Limburg and how people imagine carnival to be a vital aspect in the experience of strong regionally felt identities within the province. In Section 3.2 I explain why I selected the carnival association of De Katers for fieldwork during their 2012-2013 season and how I 'got in.' Section 3.3 reflects upon the ethical considerations and other practicalities of doing fieldwork at the carnival association. This chapter provides context for Chapters 4 and 5 about, in general, carnival celebration and, in particular, carnival celebration practices at De Katers carnival association.

\subsection{Carnival celebration practices in Limburg and at De Katers carnival association}

Carnival could be regarded as a celebration ritual that temporarily breaks with the concerns of everyday life. There are two explanations for the word 'carnival.' On the one hand, carnival may refer to the Latin words carrus navalis: a boat or ship (imitated by vessels in carnival parades) that floats into a new phase or period (see Cornips and De Rooij 2015 for the Blue Vessel tradition of Heerlen). On the other hand, carnival may be derived from the Latin carnelevarius or the Italian carnevale that literally means 'goodbye, meat' (Harris 2006: 58). In this latter explanation, carnival is presented as a Catholic celebration before the start of Lent, the forty-day fasting period of Catholics. Regardless of which explanation applies, both explanations mark a transition: either from winter to spring or from 'normal days' to Lent. From these early-day carnival practices onwards, carnival celebrations developed their own local traditions and rituals all over the world (see Henderson and Thompson 2005). Despite local variations, carnival celebrations are usually carnivalesque in nature (Bakhtin 1984: 122-123) by suspending hierarchies and allowing for free and familiar contact and new, eccentric modes of interrelationship between people. This results in carnivalesque mésalliances where combinations are to be found between "the sacred with the profane, the lofty with the low, the great with the insignificant, the wise with the stupid" (ibid: 123).

In the Netherlands, carnival, understood as the feast of the Catholics prior to Lent, was nationally celebrated until the Eighty Years' War (1568-1648) and the Protestant Reformation in the $16^{\text {th }}$ and $17^{\text {th }}$ centuries, which halted the celebrations (Van der Schee 2013). It was not until the $18^{\text {th }}$ century, under the influence of German traditions, that carnival was revived in the southern (Catholic) parts of the Netherlands (ibid). Nowadays the 
intensity of carnival celebration is highest in the southern provinces of Noord-Brabant and Limburg, where public services are closed during carnival days (Den Besten 2014; Helsloot 1981). Obviously, residents in both provinces would argue that 'their' way of carnival celebration is better than any other form. Moreover, they usually perceive the celebrations in these two provinces as different. In Noord-Brabant people refer to their carnival celebration practices as the Burgundian form of carnival, which includes modest clothing (such as old-fashioned smock-frocks) and the changing of place-names into carnival names (the city of Eindhoven, located in the east of Noord-Brabant, becomes Lampegat, which refers to the origin of the light bulb industry of Philips). In Limburg, carnival celebration practices are similar to Rhinelandic forms of carnival, which are influenced by celebrations that originated in Germany and are usually characterized by exuberant clothing and the celebration of carnival within kingdom-like carnival associations. From 1823 onwards the bourgeoisie from Köln, Aachen, and Mainz initiated the organization of parades during the period of carnival, or Fastnacht, which included princes, guards, and councils of eleven who paraded through cities on vessels (or floats that looked like vessels) to commemorate the time that Germany was an empire (Wijers 1995: 11). ${ }^{13}$ The bourgeoisie of what is now called (Dutch) Limburg were inspired by these German examples and copied these carnival celebrations. From then on, more and more carnival associations were established: the fraternity association of Momus started organizing carnival in Maastricht from 1841 onwards, Jocus was established in Venlo in 1842, De Marotte became Sittard's carnival association in 1882, and the fraternity of De Flarusse initiated carnival celebration in Roermond in $1884 .{ }^{14}$ In addition, cities and villages in Limburg developed their own local events and characteristics in carnival celebration (ibid). One of the traditions that can be found throughout Limburg is items in the colors red, yellow, and green, also referred to as vastelaoves kleure, the carnival colors. ${ }^{15}$

Originally, Catholic carnival was only celebrated with luxurious food and drinks on Shrove Tuesday, the day before Ash Wednesday when Lent officially starts (Harris 2006: 60). Nowadays, it is celebrated on the seventh Sunday before Easter Sunday and lasts for three days. In many cities and villages within Limburg, the 'actual' carnival days do not just start on the seventh Sunday before Easter. Increasingly, carnival celebrations within Limburg start as early as Thursday, Friday or Saturday, which means that some people may celebrate carnival up to four or five days instead of three.

In Limburg, carnival is regarded as the heydays, during which characteristics of

\footnotetext{
${ }^{13}$ The number eleven can be seen as a recurrent theme in carnival celebrations. It is believed that eleven stands for the 'number of fools,' since it is just one figure less than the 'number of perfection,' twelve. The council of eleven could be a reference to this fool's number. Moreover, the opening date of the carnival season of November 11, or 11/11, may be linked to this fool's number. For more information, see: http:// www.staff.uni-mainz.de/willi/mainz/fastnacht/narrenzahl.htm.

${ }^{14}$ The carnival associations Momus (Maastricht) and De Flarusse (Roermond) both ceased being carnival associations but had their second beginnings as De Tempeleers in Maastricht (1945) and D'n Uul in Roermond (1936). Some regard the Jocus carnival association from Venlo as being the oldest association of the Netherlands (De Jager n.d.).

${ }^{15}$ Fransen (n.d.) explains that the colors red, yellow, and green originated from a group of jesters that lived in the French city of Dyon in the 1450s (see http://www.fen-nederland.nl/algemeneinformatie/het-verschijnsel-carnaval).
} 
'Limburgerness' (cf. Thissen 2013) are reproduced, accentuated, and celebrated: the joiede-vivre lifestyle, the Catholic religion, and the local dialects (Wijers 1995). Wijers' ethnographic research shows that people generally perceive carnival as inextricably linked with a so-called Limburgian identity (ibid: 342-347). The use of local dialects plays an important role during carnival celebrations in order to produce regional and local identities within the context of Limburg (Cornips \& De Rooij 2015; Wijers 1995). Referring to carnival with the Dutch word carnaval is not very common in Limburg. The dialect word vastelaovend is much more in use (except in Limburg's capital of Maastricht, where people call it carnaval). Vastelaovend is connected to the Dutch word vastenavond and the German word Fastnacht and refers to the night before Ash Wednesday. This dialect word for carnival is used more than the Dutch word carnaval, which illustrates the prominence of dialects as part of vastelaovend. While dialects in Limburg are spoken throughout the year, their prominence increases during carnival, exemplifying the carnivalesque nature through which everyday routines are turned upside down (Kroon and Swanenberg 2015).

Approximately $50 \%$ of the inhabitants of Limburg celebrate carnival: between $70 \%$ and $75 \%$ of people 18 to 29 years old; $65 \%$ of people 30 to 49 years old; and $39 \%$ of people who are 50 years or older (Flycatcher 2015). Obviously, these numbers only provide a rough estimation of the total number of carnival celebrators in Limburg, since the definition of 'celebrating carnival' differs by person in intensity and activity. Overall, however, the numbers seem to have decreased over the years due to the aging of the Dutch population (cf. Flycatcher 2015; Urlings 2015ab).

\section{The celebration of carnival in associations}

There are roughly two kinds of carnival celebration in Limburg: people may either celebrate it in cafes alone (as einzelgenger), with friends, family and/or as a musician in an amateur music band or, in contrast, people get involved in carnival associations. The former is usually much less organized, while the latter follows routines and has kingdom-like structures. Although carnival associations interact with each other, they are continuously marking their distinctiveness through central figures, songs, clothing, dance, and other symbols. The study of carnival associations and the ways they relate to and distinguish themselves from each other offers interesting insights into this research investigating meaning-making practices within places through language. In the coming chapters, I will examine this within the realm of De Katers, a carnival association celebrating a more institutionalized mode of carnival within a hierarchical and ranked organization (Cornips and De Rooij 2015).

Vastelaoves Vereniging (VV), or the carnival association of De Katers (The Tomcats), was founded in 1946 in the then still independent municipality of Maasniel, Neel in dialect. Maasniel is located on the east side of the city center of Roermond (see Figure 3.1). 
Figure 3.1: Google Maps screenshot of Roermond with borders of Maasniel highlighted (Image by Google Maps, courtesy of Google Maps).

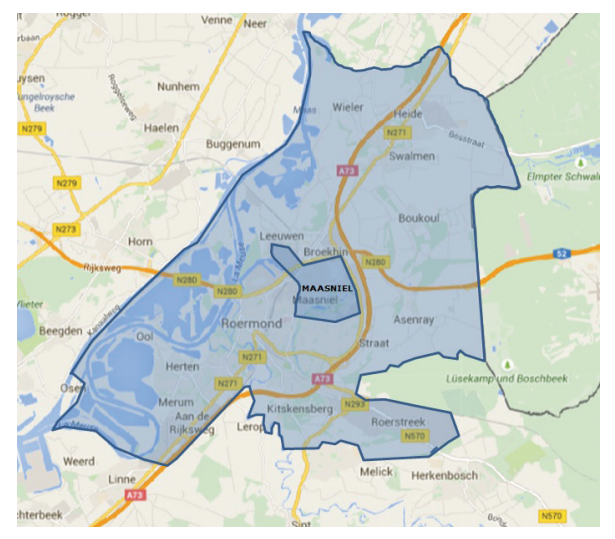

In Dutch, the word kater does not only mean 'tomcat' but can also be translated as 'hangover.' This was - surprisingly, considering the many liters of beer that accompany carnival celebration - not the reason why association members decided to call themselves De Katers. The association's website recounts how the members of the then still nameless association were celebrating their first vastelaovend in 1946. Since they lacked proper costumes, they wore their coats inside out (De Katers 1990: 16-18). Eventually, this provisional council of eleven ended up in a café in another village:

Toen men door de kasteleinsvrouw van een glaasje bier voorzien was, liep er opeens een grote zwarte kater door de zaak. Een van de leden van de Raad riep toen enthousiast, "wij noemen ons 'de Katers.'" Maar nu het mooiste, datzelfde lid van de Raad pakte de Kater op en begon hem te aaien, terwijl een ander raadslid de Kater in zijn staart kneep. Wat deed die Kater toen, hij plaste het pak van het betreffende raadslid helemaal nat. Toen stond de naam van de vastelaovesvereniging uit Neel zeker vast; $V V$ de Katers.

Beer had just been served by the [female] bartender, when suddenly a big, black tomcat strolled through the pub. One of the members enthusiastically exclaimed, "We call ourselves De Katers!" Yet, to make the story even better, the same member picked up the tomcat and started to pet it, while another council member pinched its tail. What did that tomcat then do; he urinated on the suit of the member who was holding him. That was the moment that the name of our association from Neel was decided: VV [vastelaovesvereniging] De Katers (De Katers website, History page).

Eventually, De Katers developed into an official carnival association. In the 20122013 season, during fieldwork, the carnival association celebrated its 66th anniversary and organized special events to honor this. ${ }^{16}$ From its establishment onwards, De Katers

\footnotetext{
${ }^{16}$ Because of the symbolism regarding the number eleven, carnival associations in Limburg usually celebrate anniversaries based on eleven-year cycles: $1 \times 11,2 \times 11$, etc. This also holds true for the anniversaries of members.
} 
carnival association witnessed and contributed to the development of the hostile history between Maasniel and the city of Roermond, which eventually ended with the annexation of Maasniel by Roermond in 1959. Although it has been more than 50 years since Maasniel became part of Roermond, many inhabitants still perceive Maasniel as an independent village and see Roermond as 'the villain.' These feelings are core to what De Katers carnival association represents and carries out: it is from Maasniel, not Roermond. Instead of studying the prestigious and well-known Sjtadsvastelaovesvereniging D'n Uul (The Owls city center carnival association) of Roermond, I was interested in how a carnival association, which regards itself as standing in stark opposition to the city center's association and as being part of a peripheral area within the city, uses carnival as a stage to construct linguistic and cultural difference, mainly against a perceived shared enemy: Roermond. I will return to this hostile history between Maasniel and Roermond and its influence on place-making processes within De Katers in Chapter 4.

For De Katers, as for other carnival associations, carnival is not just the three-day celebration in either February or March when people dress up like clowns, animals, or mythical creatures, watch parades, and drink beer on the streets or in crowded cafés. Most carnival associations start their events from November 11 onwards. These events are part of the pre-season (veursezoen in dialect), which refers to the weekends between New Year's and the actual three (or more) days of carnival prior to Lent. Monarch Eric, who was the head of the carnival association of De Katers at that time (see following section), even stated that:

\section{Extract 1}

Eric: Det is dökker op vriedigmiddig, dan dink ich: och nog ein paar daag en dan is 't aafgeloupe. Dan kieke miense dich aan zo van: hè veer beginne toch net pas?

Often on Friday afternoon [before the original three days of carnival], I think: gosh, just a few days and it's over. Then people look at you like: huh, we have only just begun?"

(Interview with Monarch Eric, November 7, 2014)

I surmised that the more institutionalized celebration practices at carnival associations suited my research best due to the higher degree of organization and the longer period of celebration, whereas celebrations on the streets and in cafés are more chaotic (Cornips \& De Rooij 2015). Moreover, carnival associations generally have a more conventionalized use of language, which is due to the receptions and theater nights at carnival associations where people give speeches or perform (verbal) sketches. The season of 20122013 was relatively short, since carnival fell in early February, which significantly reduced the length of the pre-season.

\section{Structure and organization of carnival associations, De Katers in particular}

Carnival associations throughout Limburg have similar kingdom-like structures, including particular central figures and departments. In order to make the organization of carnival associations comprehensible, I display the structure of De Katers association in Figure 3.2, although I should stress that other carnival associations in Limburg might have different structures and fulfillments of particular positions, since this can be an important way of 
distinguishing themselves from other associations. For instance, during fieldwork all positions at De Katers carnival association mentioned below were fulfilled by males, whereas some carnival associations in Limburg also appoint female princes or guards.

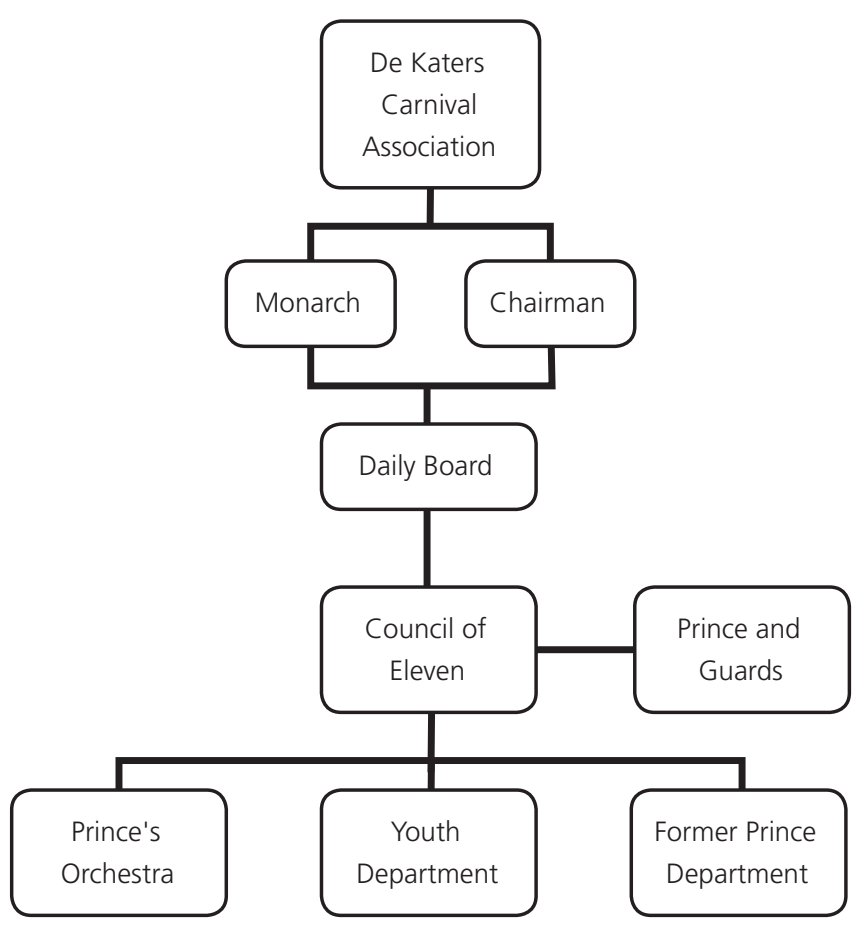

Figure 3.2: Diagram of the structure and organization of De Katers carnival association.

In general, the structures of carnival associations include a monarch, a chairman of the board, a council-of-eleven or raod van ellef of at least eleven members or ministers (Wijers 1995: 7), a prince carnival, an orchestra, a majorette dance group (De Katers does not have that), and a youth department. Figure 3.3 describes the roles and functions of the specific central figures and departments at De Katers carnival association. 


\begin{tabular}{|c|c|}
\hline Central figure/department of carnival association & Roles and functions \\
\hline Monarch (Vors) & $\begin{array}{ll}\text { - } & \text { acts as the on-stage host during events } \\
\text { - } & \text { usually appointed for } 11 \text { years }\end{array}$ \\
\hline Chairman (Veurzitter) & $\begin{array}{ll}\text { - } & \text { backstage all-rounder arranging practical } \\
\text { things } \\
\text { - } \quad \text { head of the board }\end{array}$ \\
\hline Board (Besjtuur) & 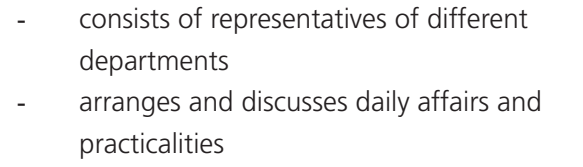 \\
\hline Council of Eleven (Raod van ellef) & $\begin{array}{ll}\text { - } & \text { consists of (male) members and former } \\
\text { - } & \text { princes } \\
\text { at least } 11 \text { members must be present } \\
\text { during events } \\
\text { - } \quad \text { supports prince during his regency season } \\
\text { - }\end{array}$ \\
\hline Prince and guards (Prins en adjudante) & $\begin{array}{ll}\text { - } & \text { the symbolic leader of the association } \\
\text { - } & \text { gets elected every season } \\
\text { - } & \text { supported by two or three guards }\end{array}$ \\
\hline Prince's orchestra (Prinsekepel) & $\begin{array}{l}\text { - } \quad \text { the musical accompaniment for the } \\
\text { association }\end{array}$ \\
\hline Youth department (Jeug aafdeiling) & $\begin{array}{l}\text { - } \quad \text { the department for children } \\
\text { - has its own board, monarch, council of } \\
\text { eleven, prince and guards, and orchestra }\end{array}$ \\
\hline $\begin{array}{l}\text { Serious Neelder Former Princes Fraternity (Sere-jeuze } \\
\text { Neelder Aad Prinse Sociëteit, SJNAPS) }\end{array}$ & $\begin{array}{l}\text { - all former princes of the association are } \\
\text { automatically part of this departmenthas } \\
\text { its own board, monarch, council of } \\
\text { eleven, prince and guards, and orchestra } \\
\text { - } \quad \text { meetings are exclusively for former } \\
\text { princes } \\
\text { - } \text { the newest former prince is lowest in } \\
\text { rank }\end{array}$ \\
\hline
\end{tabular}

Figure 3.3: Descriptions of roles and functions of central figures and departments of De Katers carnival association.

In the following I will describe the central figures and departments using insights from and photographs taken during my fieldwork at the carnival association of De Katers. Usually, there are two main characters that are easily visible on stage: the monarch and the prince (see Figure 3.4). 


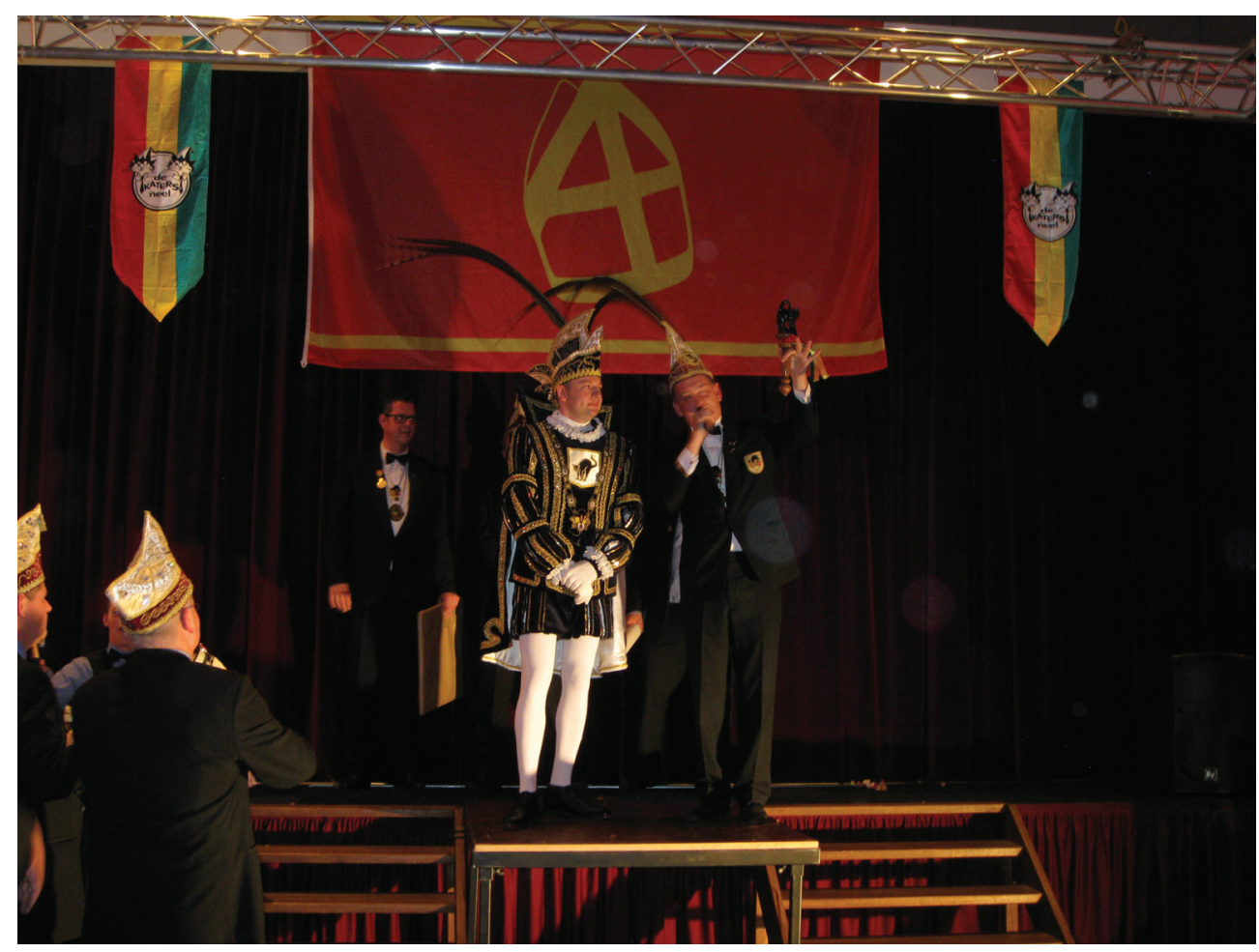

Figure 3.4: Photo of the monarch of De Katers (right) and Prince Tim I (left) during the inauguration of the prince (taken by the author, November 17, 2012).

The monarch (see Figure 3.3) is the highest ranking member of the carnival association. His main task is to represent the carnival association during the association's own events as host, but also to give speeches at receptions of other carnival associations. At De Katers carnival association the monarch wore a hat with three feathers and a black tuxedo with the emblem of De Katers. At the time of my fieldwork, Eric (himself a former prince of De Katers in 1994) had been the monarch since 2003. Although he very much enjoyed the role of monarch, he always needed some time at the beginning of a season to get used to speaking on stage. The suit and feathered hat facilitated this:

\section{Extract 2}

Eric: Ich höb ein bietje opsjtart neudig, in ieder geval efkes dae aanloup neudig. En esse d'r einmaal weer inzits en det pak aan höbs en de muts op höbs, dan geit det auch waal weer.

I always need a little start-up, at least just a run-up. And once you started, you are absorbed again and if you wear the suit and the hat, then everything is alright again.

(Interview with Monarch Eric, November 7, 2014) 
Within De Katers, the function of monarch usually lasted for eleven years, although it could be extended or shortened depending on the personal situation of a monarch and whether there was a capable successor. ${ }^{17}$

The other character that is easily recognizable during carnival events is the prince (see Figure 3.3). A carnival prince is elected every season as the (symbolic) leader of the carnival association. At De Katers, they announced both a youth prince and an adult prince. Carnival associations in Limburg announce a carnival prince approximately two months before the actual days of carnival, but the discussion of whom to select as prince can start well in advance. At De Katers, the prince selection committee gathers during the summer to approach a new prince, once the committee has agreed on one particular person. The prince has to have a clear connection to Maasniel and has to be an active participant in its community life (for example, in the carnival association already, the football club or the home guard). ${ }^{18}$ Until the actual day of the announcement, the only people who are informed are the selection committee, the prince himself, and his closest family and friends (usually his wife, parents, and his guards). In July 2012, I had an exploratory conversation with Jos, chamberlain of the Roermond department of the dialect organization Veldeke Limburg. Although our conversation was initially meant to discuss Limburgian dialects, the topic soon changed to carnival associations in Roermond. Jos was, at that time, a member of the orchestra of De Katers and former prince of 1993. According to Jos, the prince selection is supposed to remain a mystery until the announcement:

\section{Extract 3}

Jos: $\quad$ The prince selection [of De Katers] is taking place approximately right now [July]. There is much mystery involved and then the gossip starts. Here in Neel [Maasniel] it begins during the summer's fun fair: everybody is there on Sunday while keeping an eye on the people to whom the monarch and chairman are talking. Things went wrong in the past, but only once. That is the worst thing that can happen to a prince. And I remember that when e-mailing wasn't that old yet, we saw that we included the upcoming youth prince and his guards in the CC of an email. Luckily, nobody else noticed it.

(Field notes, July 2, 2012)

A prince can be recognized by his costume and attributes. After the announcement, the monarch bestows upon him a hat with three feathers, a scepter shaped as a tomcat that symbolizes the reign of the prince over the Kater-empire, and a golden chain of office. When being announced and during the actual days of carnival, the prince wears a princesuit that consists of white tights and a diamond-decorated suit and cape. A large emblem of a tomcat is found on the chest of the prince (as depicted in Figure 3.4). The colors of the suits may vary depending on the prince's taste. De Katers board has the policy of financially supporting the prince themselves. They finance the suits, scepter, and feathers, but also give the prince some spending money to use during the season. In that way, I was

\footnotetext{
17 On November 22, 2015, at the beginning of the 2015-2016 season, Eric resigned as monarch and replaced Leon as chairman of De Katers. From then onwards, Wil, a council-of-eleven member and former prince of 2004, replaced Eric as monarch.

${ }^{18}$ Conversation with Leon and Thei, October 1, 2012 and interview with Eric, November 7, 2014.
} 
told, everyone could potentially become a prince, no matter whether he was the son of a notary or the son of a carpenter. ${ }^{19}$ In return, the association maintains some influence over what princes should wear (see Chapter 4).

Apart from suits and attributes, a prince has a slogan that characterizes him and that he will exclaim during events. Most of the time the slogan specifically refers to his job or hobby, but it can also refer more generally to carnival and accompanying themes (such as beer, music, or dancing). For instance, Prince Tim I of the 2012-2013 season was an electrician, which inspired him to come up with the slogan: lempkes aan...veer gaon draan (lamps on...we're cutting loose). Lastly, most of the time a prince is surrounded by his guards (adjudante), usually two or three men who support him during the season by getting him drinks and carrying gifts, helping him with his hat when he receives a medal, and driving him to visit other carnival associations (see Figure 3.5).

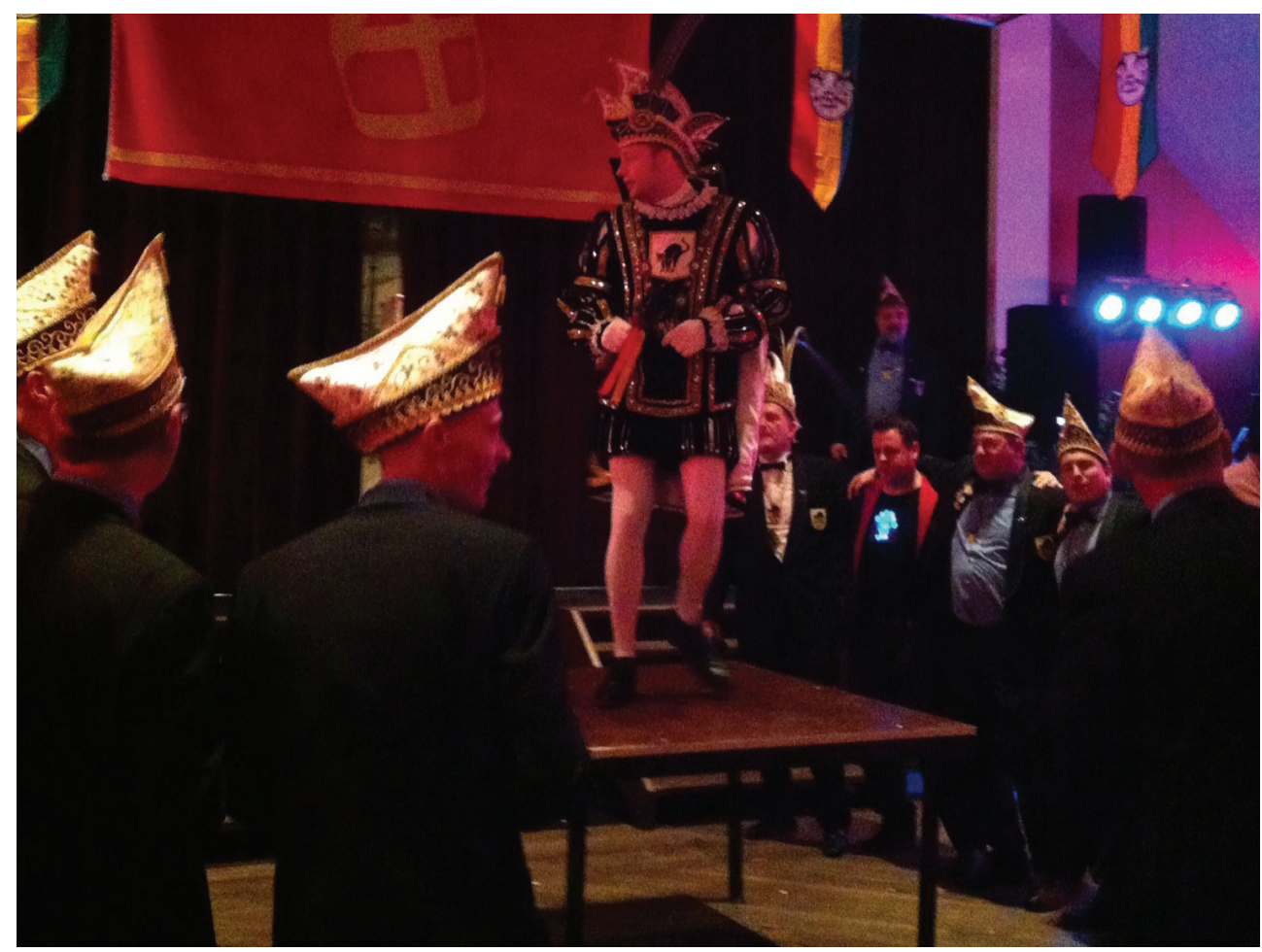

Figure 3.5: Prince Tim I dancing on the table, surrounded by the monarch (in tuxedo with feathers), one prince's guard (red lapelled jacket), and members of the council of eleven (taken by the author, November 17, 2012)

Besides these main characters on stage, there is a chairman who arranges many things backstage, such as bringing the hats during the opening of the season (see Section 3.2). In addition, the chairman chairs the board of the carnival association and the evaluation meetings. During my time at De Katers, Leon had already been the chairman

\footnotetext{
${ }^{19}$ Field notes, conversation with Leon, February 22, 2013.
} 
of De Katers since 1981. At the time I met him in October 2012, he had been chair of the association for 31 years. ${ }^{20,21}$ The general board that Leon chaired meets on a regular basis. During these meetings the men take care of business regarding the season: budgets, appointments to visit other carnival associations, planning of events, evaluations of events, etc. The prince and his guards are not part of this general board; they have separate meetings with the daily board (monarch, chairman, and secretary), and after the season they visit the board meeting to evaluate how things went.

Other departments within De Katers are the council of eleven, the prince's orchestra, the club of former princes, and the youth department. At the time of my fieldwork at De Katers, the council of eleven consisted of twenty-four members. Unlike the prince, the council of eleven does not change each season, but members may join or decide to stop as they wish. Members of the council wear black suits, blue blouses, and red-and-creamcolored bicorn-shaped hats with golden stitches, blue diamonds, and a tomcat emblem (see Figure 3.6). The council is present during all events of the carnival association but also during visits to other carnival associations. During these visits it is deemed essential that there be at least eleven members present. If not, this could be interpreted as an insult to the receiving carnival association. Furthermore, the members of the council help out during events by tapping and serving beer, cleaning up, welcoming people at the door, and building stage sets.

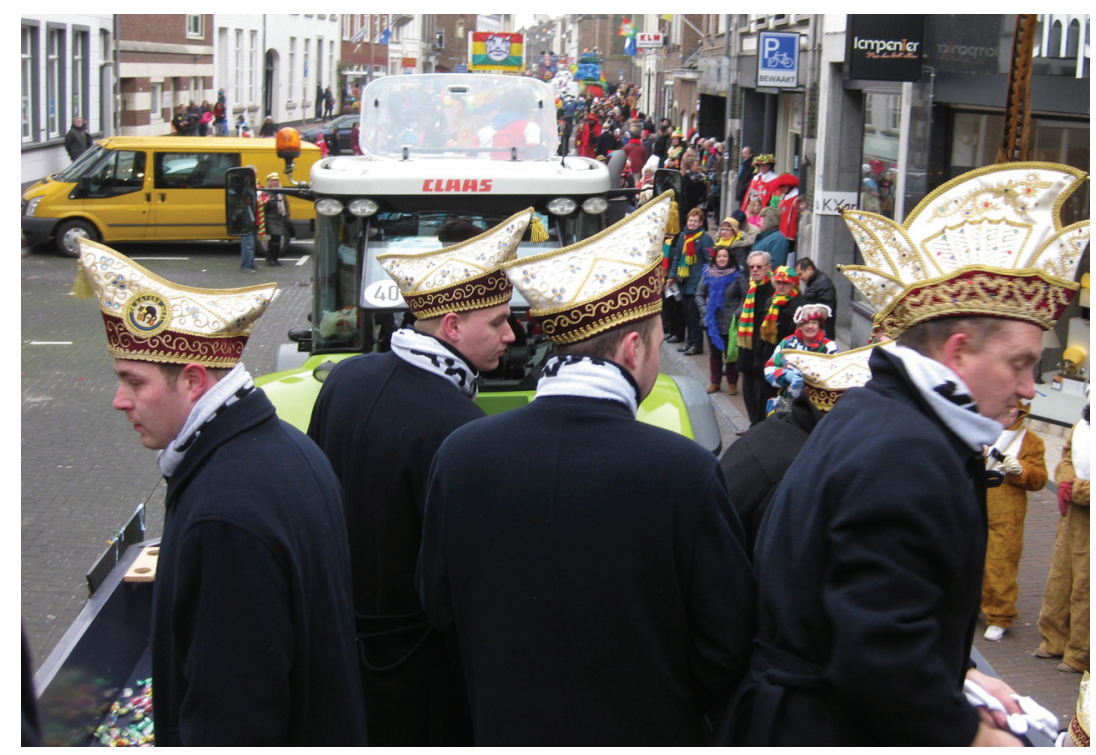

Figure 3.6: Photo of members of the council of eleven (bicorn-shaped hats) and the monarch (feathered hat) on De Katers carnival association's vessel during the parade in the city center of Roermond (taken by the author, February 11, 2013).

\footnotetext{
${ }^{20}$ In the 2014-2015 season, Leon received the Royal Medal of the Netherlands to honor his overall efforts for the past 33 years at De Katers from Maasniel, see: http://roermond.nieuws.nl/nieuws/10314/koninklijkeonderscheiding-voor-leon-hamans-66-uit-maasniel/

${ }^{21}$ After 34 years, Leon resigned as chairman of De Katers.
} 
The prince's orchestra, or Prinsekepel (abbreviation PK), is the association's accompanying orchestra that, at the time of my fieldwork at De Katers, consisted of eighteen musicians. The musicians do not necessarily have to be members of De Katers; above all, they are in it for the sake of making music. The PK is one of the showpieces of De Katers, since many carnival associations struggle to find good musicians for their carnival orchestras. For Monarch Eric, the orchestra appeared to be of enormous value during visits to other carnival associations:

\section{Extract 4}

Eric: Veer höbbe de Prinsekepel en det sjaelt natuurlik waal heel veul en det is auch de sjterke krach van os; doe kums mit meziek binne dus de hoofs dae prins, hoof neet per se dan mit ein leedje beveurbeeld want dae kump met dae kepel binne, dae sjpringt dae taofel op en dae sjteit er al, dus det is auch waal heel erg leuk. Esse mit meziek binne kins trekke, det guf dich geweun 'ne kick en det is waal heel erg leuk.

We have the Prinsekepel and that makes a huge difference and that's our power: you enter with music so the prince, he does not need a song, for example, because he enters with the kepel, he jumps on the table, and he just makes an appearance, so that is also very nice. When you can march in a room with music, that just gives you a kick and it's just fun.

(Interview with Monarch Eric, November 7, 2014)

On the day that the new prince is announced, the previous season's prince is decrowned and taken up into SJNAPS, an abbreviation for Sere-jeuze Neelder Aad Prinse Sociëteit (Serious Neelder Former Princes Fraternity). ${ }^{22,23}$ Before this happens, he is allowed to exclaim his slogan once more and to acknowledge some people. Then the monarch of the association divests the prince by taking his chain of office, his feathers, and his scepter. He is allowed to keep his prince's hat and receives a medal. Immediately after this, all the former princes of SJNAPS get on stage to welcome the newest former prince into their club. In SJNAPS, the newest former prince is lowest in rank and has to prove his membership by gulping down a large pint of beer on stage. There is an air of mystery to this former princes department: their meetings are secret, and no one else is allowed to join the meetings, except former princes. ${ }^{24}$

Carnival is not only for grown-ups; while grown-ups are partying, their children need to be entertained as well. This is what the youth department is for. The youth department resembles the grown-up department in that it is also guided by a board and a council of eleven, announces its own youth prince, has a youth orchestra, and has a residence

\footnotetext{
${ }^{22}$ For the former youth prince, there is no such group to join after his de-crowning. He will be included, though, in the association's Hall of Fame (see http://dekaters.nl/historie/aad-jeugprinse/).

${ }^{23}$ Sjnaps refers to the German name for small liquor shots (schnaps). Writing 'sj' instead of 'sch' used in German indicates dialect writing within this context of Limburg.

${ }^{24}$ During the jubilee reception of the 2012-2013 season, chairman Leon was given an honorary position within SJNAPS to make up for the fact that he, in 31 years, had never been announced as carnival prince a position he himself did not want, since he refused to be the center of events.
} 
club where the youth of De Katers gather, drink soft drinks, and dance. The adult prince, monarch, and council of eleven make sure that they visit this youth club regularly to give them the feeling of being engaged in the association as a whole.

During the 2012-2013 season, the carnival association of De Katers counted 480 members, which included 90 members who were actively involved in the (youth) council of eleven, (youth) board members, or (youth) orchestra. The other 390 were 'regular' members who paid a membership fee (personal communication with Maurice, De Katers' secretary, 2015). These members did not have a role in the association (such as being a member of the council or orchestra). Membership of De Katers, at 33 euros per year, includes the yearly magazine KlassjeNeel. Members also obtain discounts on particular items (like De Katers flags, compact discs, or on tickets for the theater nights). For the most part, the audience attending carnival association events included some of these members.

It is striking to see the gender patterns within De Katers' structure and hierarchy. The monarch, chairman, (youth) prince, and council of eleven members are always male. In the hierarchy and agenda, women are mostly invisible. It is only within the orchestra and the youth department that one can find female musicians or female members that support the children's activities. Besides this, women are found in creative functions (for example, clothing and decor design) and get on stage during theater events. In the audience, the wives of the council of eleven mostly stand together and usually do not stand next to their husbands (see Chapter 4). There is, however, an event that is known as the vrouwluujzitting: a women's gathering organized for women from Maasniel where no men are allowed. This certainly does not hold true for every carnival association in Limburg: there are associations where the divisions between men and women are more balanced.

\subsection{Doing ethnographic fieldwork at the carnival association of De Katers}

\section{Getting fieldwork started}

Before conducting my research, I had always celebrated carnival on the streets and in cafes with family and friends, so I was not very familiar with carnival as celebrated within carnival associations. At the time when I was deciding upon which carnival association I would join for fieldwork, the municipality of Roermond counted seventeen carnival associations in total. ${ }^{25}$ I had to make an informed decision about which carnival association it would be best to join.

My exploratory conversation with Jos, chamberlain of the Roermond department of dialect organization Veldeke Limburg, turned out to be decisive in choosing a carnival association. Jos' enthusiast stories about De Katers and its history with Roermond aroused my interest in the carnival association from Maasniel. Jos put me in contact with the chairman of De Katers, Leon, whom I met in October 2012 in his tomcat-decorated house,

\footnotetext{
${ }^{25}$ Roermond's seventeen carnival associations at that time were: De Bacchusklup, De Kwekkerte, Vader Aartje Asselt, De Plekkers Merum, De Waterratte Ool, Kits-Uule Remunj, De Nachtegale, Koelbertus, D’n Uul, De Hopsjlokkers Zjwame, De Donderböl, De Fobmötse, De Haofgengers, De Kaketoes, De Katers, De Tuinhagedisse, and De Veldjmuus (see http://lokaaltotaal.nl/roermond/organisaties-en-verenigingen/c/carnavalsverenigingen).
} 
where I informed him and Thei, former Kater prince of 1972 and Leon's advisor, about what my research would entail. After our conversation, the men granted permission to follow their carnival association during the 2012-2013 season. A few weeks later, I joined the official opening of the season on November 11, 2012, the first day of fieldwork on which the peculiarities of De Katers immediately came to the fore, as the following vignette describes: 26

"The hats are here!" Chairman Leon of De Katers carnival association enters the association's residence café, De Ster (The Star), with a box full of hats. It is November 11, 2012, the starting day of the carnival season. I find myself in a crowded café in the former village of Maasniel and see how members of the association's raod van elf, the council of eleven, look at the chairman with excitement. The chairman announces the names that are written in the bicorn-shaped hats and gives them to the corresponding members. On the left side of the hat, the emblem of a black tomcat with an arched back is shown, revealing the member's affiliation to 'The Tomcats,' De Katers. When being reunited with their beloved hat, the men joke about the smell of the hats and wonder if they will still fit after last season. To figure that out, they will have to wait until 14:11 p.m., the moment on November 11 that the carnival season of De Katers is officially opened and that members are allowed to put on their hats again. While handing out the hats, the chairman informs the monarch about my presence, and I introduce myself to him and the rest of the association's board.

Instead of talking in dialect, as they do among each other, they keep switching to Dutch when addressing me. By stoically talking dialect myself, I try to convince them that they do not need to switch to Dutch, which they only seem to accept after a few weeks. While the café gets even more crowded, the monarch asks why I will join them this whole season. I tell him that I am doing research concerning language practices and culture in Roermond. He waits for a moment and responds: "Roermond... And Neel?" While I start to defend myself that I know that Maasniel, or Neel in dialect, is officially part of Roermond, the monarch immediately interrupts: "Sorry? Lesson one: on August 1, 1959, Neel was annexed by Roermond!" There it is, my first fieldwork blunder: although Maasniel belongs to Roermond on paper since 1959, people still imagine and reproduce a strong collective village identity, which is mainly fostered by the carnival association. So far, two things are clear: I do not look like someone who talks dialect and this place is not Roermond.

When all the members of the council have received their hats, we leave the café and walk to the central plaza where a billboard, with the logos of De Katers and Maasniel and two painted tomcats, is put up behind a microphone. A few inhabitants of Maasniel are present to watch the opening and are welcomed by the monarch. After the prince's orchestra has played the song that is emblematic of the association, Neel blief Neel (Maasniel remains Maasniel), the carnival prince and youth carnival prince of the previous season join the monarch on stage to open the new season and to be reunited with their feathered hats, chains of office, and

\footnotetext{
${ }^{26}$ The following vignette is compiled from field notes taken during the opening of the carnival season.
} 
scepters. They won't be princes for long though, since the princes of the new season will be announced one week later. After the re-commissioning of the princes, the members of the council are allowed to put on their hats while the orchestra plays the association song once more. Finally, the eleven cannon shots of the Neelder guard make the opening of the carnival season of 2012-2013 complete. (Field notes, November 11, 2012)

Already within the first hour of my fieldwork, members of De Katers clearly distinguish themselves and the former village of Maasniel from Roermond. Besides this, the vignette shows how the use of dialect seems to be associated with not only carnival celebration but also with particular people and place-naming (Neel). Apparently, I am not perceived by the members of De Katers as a dialect speaker right away, even though my dialect use is very similar to theirs - although some label their dialect Neels, the differences between Roermond and 'Neels' dialect are really minor (see also Chapter 5). These very first fieldwork experiences supported my assumptions about De Katers being an interesting research site for conducting a study on language and meaning-making practices.

When the opening event started on the central plaza of Maasniel, the Monarch introduced me, in dialect, as a lady doing anthropological research on De Katers:

\section{Extract 5}

Eric: En veurdet veer 't sezoen sjtarte, noe mot geer heel efkes kieke, naeve Leon Hamans, dao sjteit 'n dame, det is Lotte en dan dink g'r "wat doot die hiej, waat duit die hiej?" Nou det is eh, die duit ein antropologisch ongerzeuk en die geit nao zesenzestig jaor, eh, geit die kieke of 't allemaol waal ecologisch verantjwoord is waat $v^{\prime} r$ allemaol doon hiej in Neel. Nea, det is 'n bietje sjaele zeiver, eh, op ein sjtekske, maar zie, eh, zal waal 't sezoen mit os mittrekke en, eh, ja, meugelik kump dao 'ns een keer ein book euver oet en dan, eh, komme veer eh gaer bie de prizzentasie van 't book kieke waat't allemaol is gewaore mit De Katers in Neel en heure vastelaovend.

And before we start the season, you should have a look now, next to Leon Hamans, there is a lady, that's Lotte, and then you'll think: "What is she doing here, what is she doing here?" Well, that is, uh, she is doing an anthropological research and after sixty-six years she is going to examine whether everything is ecologically sustainable what we are doing here in Neel. No, that is tomfoolery, uh, joking apart, but she, uh, will come along with us this season and, uh, yes, possibly a book will come out about it and then, uh, we gladly join the presentation of the book to see what came out of it, with De Katers in Neel and their vastelaovend. (Monarch Eric, recordings November 11, 2012)

Besides this public presentation, the editor of the carnival magazine KlassjeNeel of De Katers asked me to write a short introduction. KlassjeNeel refers to the dialect word klasjenere, which means 'to chat' or 'to gossip.' I wrote a short piece in dialect to introduce my research and myself (see Appendix A). What was interesting was that my piece was completely rewritten and reproduced by the editor of KlassjeNeel magazine. In this, my dialect was corrected into 'proper' spelling and rephrased in a less serious and more carnivalesque tone. The different introductions into the carnival association were a big 
help, not only in getting to know people but also in easing my ethical considerations. Through the introductions, I regarded myself, as Goffman (1981) would call it, as a ratified over-hearer: most members and attendees of De Katers events were informed about my presence. Therefore, I felt comfortable about switching on my recorder immediately. Moreover, another electronic device more or less would not attract too much attention anyway, since the events were already highly mediatized: the audience and members of the carnival association themselves were taking photographs or videos with their own devices.

The many events organized by De Katers were valuable for collecting data. The events of De Katers are public and, in principle, freely accessible to anyone, yet one would probably quickly feel uncomfortable when walking in on a Kater-event without knowing anyone. In that sense, De Katers is a community where all visitors (members as well as 'regular' audience) know each other or are at least acquainted. Apart from that, being part of and attending De Katers' events is mainly regarded as a leisure activity, where people gather to spend their free time and to be entertained by the association, even though it might be strange to some that the members of the association relate to a specific hierarchy and ranking during these leisure events. Besides the leisure aspect, there are some more economic aspects within the carnival association. The carnival association organizes events that cost money: theater nights with self-built decor, prince announcements with expensive suits, and receptions with gifts. The members thus need to collect money in order to sustain these events: selling drinks during events; selling the association's magazine (with a lot of advertisements that are bought by companies); collecting scrap metal; selling memberships; organizing concerts or dance events outside the carnival season.

The planning calendar of De Katers is full and quite tight. In general, every weekend after New Year's is scheduled for an activity, and the actual days of carnival are full of parades and receptions. One thing many members complained about, for example, was that they had to leave immediately after the parade in Maasniel to visit the reception of the $D^{\prime} n$ Uul carnival association in the city center of Roermond, which is obviously a sensitive topic among the members and the audience of De Katers considering the touchy history between Maasniel and Roermond. Appendix B shows the official program that was sent around to the board, council, and orchestra of De Katers, including events such as song contests, theater shows, receptions, and parades. Most of these events had a dialect name, which again highlights the importance of dialect in carnival celebration. As the official program shows, there are many events organized by De Katers that recur every year. In short, ample events for an anthropologist to lose herself in.

\subsection{Fieldwork ethics and practicalities}

During the many events, I held informal conversations with members of the association and other attendees. Due to the noisiness of loud carnival events with live music and speeches, informal conversations were a bit more challenging to understand. As a result, recordings were not always as clear as I had hoped. Therefore, I visited the bathroom regularly to quickly scribble down notes about interesting observations and conversations. This resulted in a varied dataset; see Figure 2.1 in Chapter 2. During my fieldwork at De Katers carnival association, I often had to make important decisions about my role as a researcher and about the degree of my participation. Such decisions influenced my inclusion and exclusion among members of the carnival association and within the fieldwork site. 
In the first exploratory conversation with Chairman Leon and his advisor, Thei, the issue of roles and inclusion of the ethnographer were immediately raised. After shaking hands with him at his front door, he immediately remarked: "You are by bicycle, that's a good sign." He thereby implied that I was not living so far away as to prevent my biking to his house and I must, thus, come from nearby. He subsequently asked about my name and to which Thissen family I belonged. Right after that, the language situation was brought up: was I able to talk dialect? Leon and Thei next asked me whether I was familiar with carnival celebration at all. At the end of the conversation, I was invited to attend the opening of the carnival season. It seemed as if they could accept someone coming from nearby, belonging to a known family within Roermond, speaking dialect, and familiar with how to celebrate carnival.

It took some time until members of the carnival association seemed to include or accept me. To start with, most members were pleasantly surprised to hear that I consciously chose to study De Katers over D'n Uul carnival association from the city center of Roermond. Yet the language practices were an explicit way of giving me a feeling of being an outsider. Although I started every conversation in dialect, many members responded to me in Dutch during the first events, as described earlier. Apparently, they did not think of me as a dialect speaker, possibly due to my appearance. After the first three weekends of events, most of them eventually realized that I did speak the dialect and that I did sing along with the popular carnival songs myself, thus being more of an insider than they figured at first.

Besides this, the gender aspect played a huge role in my inclusion as an ethnographer. As explained, De Katers is an association where males tend to predominate. Being a woman in such a male-dominated carnival association sometimes felt uncomfortable, not only for me but probably also for the members themselves:

Now that the season is officially opened, De Katers are up for a pub tour through Maasniel. Almost like a procession, guided by music from the Prinsekepel, we walk from the central plaza, where the season was opened, to café 't Dörp (café The Village in dialect). While everyone finds a spot to drop their jackets and to order beer, I decide to order a glass of soda. This does not go unnoticed. A member of the council of eleven immediately yells at me: "You don't drink?" I laugh uncomfortably and I see how other members start to laugh. I could almost see them think: "How on earth is she going to survive a whole season with us without drinking?" While sipping my soda, the same member loudly remarks to me in Dutch: "The women stand over there, you know!" My mind quickly calibrates and I respond sharply in dialect: "Oh, and am I not allowed to stand with the men?" The man and his fellow members seem to be quite surprised by this. In the next café, café De Thooren (café The Tower), I order my first beer of my season among De Katers. Some men appreciatively toast with me to the new season. One member jokingly suggests that I should contribute to their collective drinking wallet. Again, I seem to surprise them by thumping some money down. "Ha! You'll never keep up with our drinking tempo! And we drink large glasses, not those small ones you drink now, you know!" Oh well, I think, maybe these beers are necessary for being accepted into this group of men. The hangover and the scribbly notes I found the day after were well worth it; the men seemed to accept me a bit more.

(Field notes, November 11, 2012) 
Especially in the beginning, my friendliness and closeness with the men of the council of eleven resulted in my being the recipient of some annoyed glances from the members' wives, since I was allowed to stand among their husbands while they were usually relegated to standing among each other. From that moment onwards, it seemed impossible to reconcile with the women of the carnival association, since the council of eleven was very proud that a researcher was actually investigating them. Likewise, my contact with the orchestra department was not as intense as with the council of eleven members. It felt like the bonding on the very first day with the council of eleven shut some doors to other departments and groups within the association. This was reinforced when I was allowed, as one of the first women ever, to be on the parade car during the parade in Roermond.

Furthermore, I also had to deal with expectations from the field about my own presence. In our first exploratory conversation, the chairman and his advisor made it clear that they also expected information from me in return. Currently, many carnival associations struggle to bind youngsters to their events, since they often prefer to go out in cities rather than villages and to attend big events instead of visiting smaller cafes. The chairman and the advisor were therefore eager to learn from me, after my fieldwork, how they could make their events attractive to young people. As an outsider to the association, I was considered to be a good consultant to provide suggestions. Since I did not want to let this interfere with my fieldwork, I decided to leave it until the fieldwork period was over. During the last evaluation meeting of the board, the question came up again, and I responded that receptions took a long time and were therefore maybe not that fun for youngsters and non-members to attend. The board seemed pleased to get this information from someone outside of the association.

The events of De Katers were already highly mediatized, which facilitated my feeling comfortable making recordings. Whenever people asked me about the thing hanging around my neck, I was always open and honest about my research and also asked them whether I should turn it off while standing next to them, yet no one ever responded or asked me to do so. More important, my research participants fully comprehended that I was making recordings and taking photographs for my research. Sometimes members would even direct my attention to something they thought I should record or photograph.

Things slightly changed when making recordings during board meetings and the so-called kotsvergadering (literally, 'puke meeting'), during which the season was evaluated by the board and members. During these meetings the (board) members of the carnival association were far more aware of the recorder. During the first board meeting, one member initially expressed some resistance to my presence and the recorder. After having explained my aims and that I could switch the recorder off immediately if he insisted on it, other board members convinced him that it was okay. Still, when members started gossiping or complaining about the behavior of fellow members or other carnival associations, they did sometimes explicitly make a reference to the recorder or ask me to switch it off for a while, which I did.

\section{Conclusion}

This chapter has dealt with the reasons why I wanted to include carnival celebration in my research. I have pointed out that carnival practices in Limburg are generally associated with 
the strong regionally felt identity of the province and that the use of what is recognized as local dialects seems to be taken for granted within local carnival celebration. This is why I included carnival celebration as an interesting case for examining language and meaningmaking practices. I carried out extensive fieldwork within the carnival association of De Katers in the former village of Maasniel, and already within the first hour of my fieldwork at De Katers carnival association, it became clear that studying language practices within carnival celebration was relevant in that members of De Katers, even within our first contact, distinguished themselves, their associations, and the former village of Maasniel from the city of Roermond as a whole. Due to the tumultuous history between the two places and the annexation of Maasniel by Roermond, inhabitants of Maasniel and members of De Katers still remembered and reproduced the independent village identity of Maasniel. This chapter has prepared the way for Chapters 4 and 5 in providing context about carnival celebration and about the particular carnival celebration practices of the association of De Katers. 


\section{Chapter 4}

\section{Neel remains Neel: Carnivalesque place-making practices at De Katers carnival association from Maasniel}

\section{Introduction}

People who celebrate carnival endow particular places with cultural and linguistic meaning through place-making processes (Creswell 1996; Pred 1985). This chapter addresses the question of how people shape understandings of locality, community, and region (Gupta and Ferguson 1997) by engaging in carnivalesque place-making practices. I study this within the confines of De Katers, a carnival association that, since its foundation in 1946, has been based in Maasniel (Neel in dialect), a former independent municipality that became part of Roermond in 1959 (Beckers 2006). In order to address how people give meaning to the everyday places in which they live, I specifically focus on place-making practices that give cultural, material, linguistic, and historical-territorial meaning to the places involved. I argue that the carnivalesque place-making practices of De Katers members consciously (re) produce a place, Maasniel or Neel, by remembering it as a distinct place in historical narratives and by using and displaying materials and language practices. Through place-making practices, De Katers carnival association is able to set itself apart from, first, the city of Roermond as a whole; second, from other areas of Maasniel; and finally, from other carnival associations, thereby producing, challenging, and resisting center-periphery dynamics in Bakhtinian carnivalesque ways. In addition to this, these place-making practices enlighten who and what behavior are considered to be in and out of place. In this introduction, I will first expound on Maasniel's history, an appreciation of which is essential to understanding place-making practices at De Katers carnival association.

Nowadays 7,540 inhabitants reside within the 'administrative neighborhood' of Maasniel within Roermond (Municipality of Roermond 2016: 22). ${ }^{27}$ Statistics about the composition of particular places or countries only give a rough estimation, since the labeling of people depends heavily on the criteria one focuses on in population censuses (Broeder and Extra 1996). The numbers in Figure 4.1 below do not provide any insight into how people identify themselves across different contexts. Nevertheless, they provide some insight into the composition of Maasniel in comparison with that of Roermond.

Of the total number of inhabitants in Maasniel $(7,540), 79.4 \%$ are reported by the Municipality of Roermond as originally coming from the Netherlands. With respect to the numbers of inhabitants from other backgrounds, the Municipality of Roermond indicates that the numbers include those who have at least one parent born outside the Netherlands. Furthermore, in comparison to previous years, people who have dual nationality other than Dutch (for example, German and Turkish) count twice, while the numbers no longer include people with dual nationality (for example, Dutch and Moroccan). ${ }^{28}$ With this in mind, $10.7 \%$ of Maasniel's inhabitants originally come from Western countries. 9.9\% originally come from non-Western countries, with a majority originally from Morocco (174 inhabitants) and Turkey (126 inhabitants).

\footnotetext{
27 I deliberately use numbers from 2016, as provided by the Municipality of Roermond, since the numbers in Figure 1.5 in Chapter 1 are also based on 2016.
} 


\begin{tabular}{l|cc}
\hline & Maasniel & Roermond \\
\hline Total inhabitants & 7,540 & 57,010 \\
Autochtoon & 5,988 & \\
Westerse allochtoon & $\underline{\mathbf{7 9 . 4} \%}$ & 40,926 \\
Niet-westerse allochtoon & $\mathbf{8 0 8}$ & $\mathbf{7 1 . 8 \%}$ \\
& $\underline{\mathbf{1 0 . 7}}$ & 8,353 \\
& $\mathbf{7 4 6}$ & $\mathbf{1 4 . 7 \%}$ \\
\hline
\end{tabular}

Figure 4.1: Composition of inhabitants (autochtoon, Westerse allochtoon, and niet-westerse allochtoon, labels used by CBS Statline) by number and percentage of Maasniel and Roermond (CBS Statline 2016).

Prior to 1959, the Municipality of Maasniel consisted of the village of Maasniel itself, the villages of Asenray and Leeuwen, and the hamlets of Broekhin, Spik (Op de Speek in earlier days), Straat (De Straat in earlier days), Maalbroek, Thusershof, and Gebroek. These villages and hamlets, which made up the former Municipality of Maasniel, are located on the east side of Roermond and are highlighted on the map in Figure 4.2.

In his historical description of the merger between Maasniel and Roermond, Beckers (2006) indicates that it was in 1946 that local governments in Limburg made plans to rebuild and modernize Limburg as soon as possible in order to cope with numerous problems in the wake of World War II. The government of Roermond proposed joining forces with the municipality of Maasniel to deal with housing shortages. This gave rise to fierce protests by the inhabitants of Maasniel, who, in the face of the 'annexation' threat, started to appreciate their taken-for-granted community with its local government, associations, and public services. They found themselves in a dilemma, since the then mayor had contributed to the development of Maasniel while, at the same time, he did not explicitly oppose plans for reform coming from Roermond. Some inhabitants organized an anti-annexation committee to convince other inhabitants that joining Roermond was not a good thing, since it was just an arrangement of the local governments with the 'nobs' of The Hague, the political heart in the western part of the Netherlands where national politicians work (Beckers 2006).

\footnotetext{
28 These people are part of the so-called third generation. They are the grandchildren of the first generation of people who came to the Netherlands and whose children were born in the Netherlands and started their own families.
} 


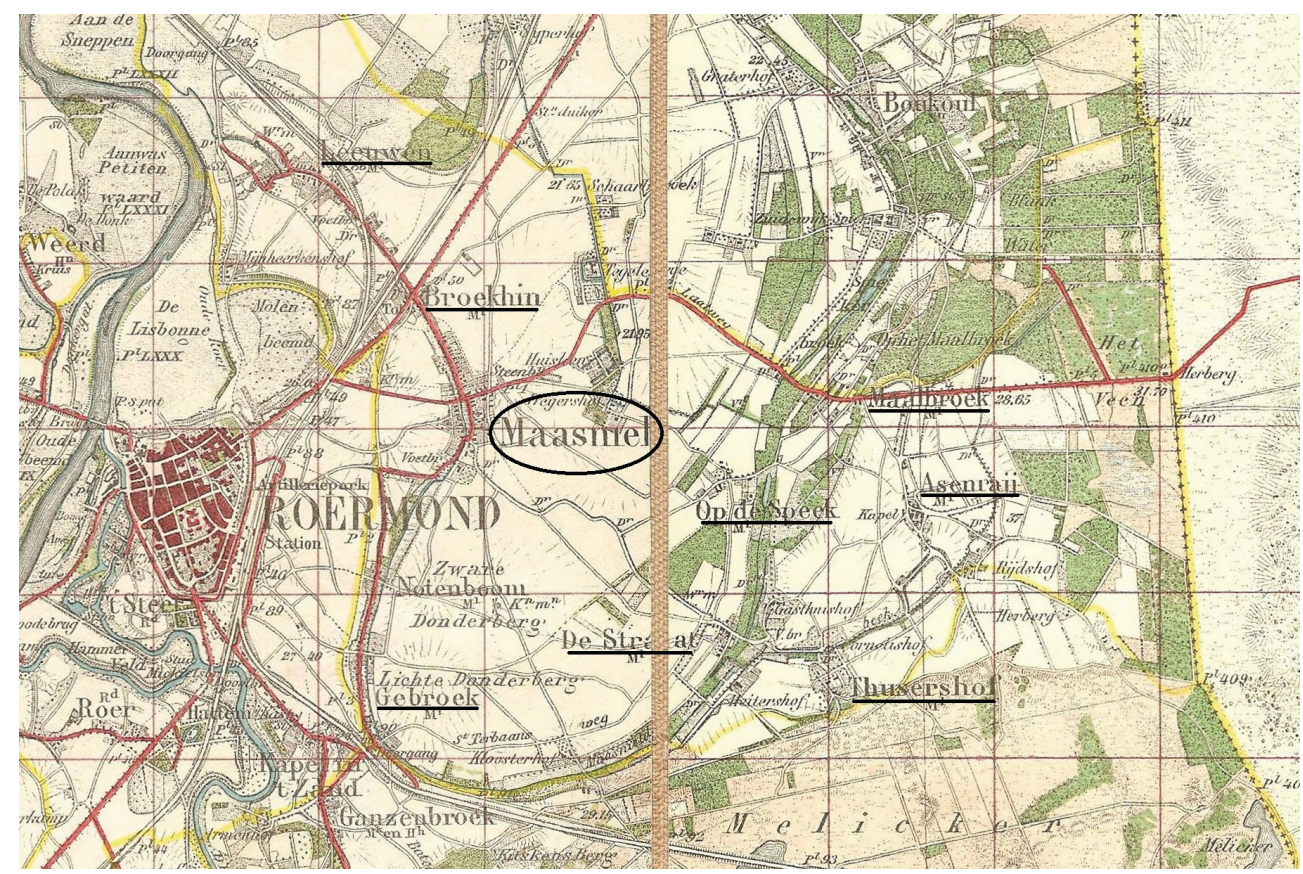

Figure 4.2: Map of Maasniel in 1842/1843 with Maasniel circled and Asenray, Leeuwen, and the hamlets of Broekhin, Spik (Op de Speek in the map) Straat (De Straat on the map), Maalbroek, Thusershof, and Gebroek underlined (Kadaster 1895, image courtesy of Dominique Clerx of website www.maasniel.nl).

It was only when the inhabitants of Maasniel realized their village would become part of another municipality that they started emphasizing their distinctiveness and remembering their local past by (re)constructing a village identity based on recognizable symbols (Beckers 2006). As such, Maasniel's incorporation into Roermond is quite similar to the negative integration of Limburg (see Chapter 1) into the Dutch nation-state (Knotter 2011). Both events raised awareness amongst inhabitants of Limburg and Maasniel that they belonged together and shared particular characteristics and traditions in constructed oppositions to other entities, Holland and Roermond, respectively.

After more than thirteen years of protest, Maasniel was eventually united with Roermond on August 1, 1959. People still assert that the 'annexation' was unjust given that Maasniel's territory was much larger than that of Roermond. From the 1960s onwards, the protests and identity construction of Maasniel - with its inherent boundary marking - have become more playful in nature and shifted from the political domain to that of cultural institutions and the carnival association of De Katers (Beckers 2006: 190). Even though the annexation of Maasniel took place more than 50 years ago, some people in Maasniel still portray Roermond as the powerful 'bad guy' that often makes decisions at the expense of Maasniel. For example, one member of De Katers thought it was a pity that Roermond decided to name the public garden in Maasniel Mevlanapark, due to its proximity to the Turkish mosque (Field notes, November 17, 2012). According to the member, many people in Maasniel would have liked the public garden to be named after Maasniel, since it was exactly 50 years ago that the former village became part of Roermond. This statement seems to convey other underlying dividing lines and asymmetrically felt power 
relations between perceived ethnic groups within current polarizing societies, since it refers to a Turkish mosque. Aside from that, the statement certainly demonstrates how the relations between Maasniel and Roermond are reproduced and regarded as being unequal; Roermond holds the power and is therefore perceived and considered as the center, whereas Maasniel is a former village in the periphery.

Moreover, Maasniel is still perceived as an oddity within Roermond. People from outside Maasniel perceive it as a neighborhood with a stronger local identity than that of Roermond's other neighborhoods, whereas residents of Maasniel recall its status as an independent municipality. Signposts at the borders of Maasniel, marking that one is entering or leaving Maasniel, demonstrate that Maasniel is not 'just' a neighborhood (Figure 4.3).

Figure 4.3: Signpost at the border of Maasniel (Neel).

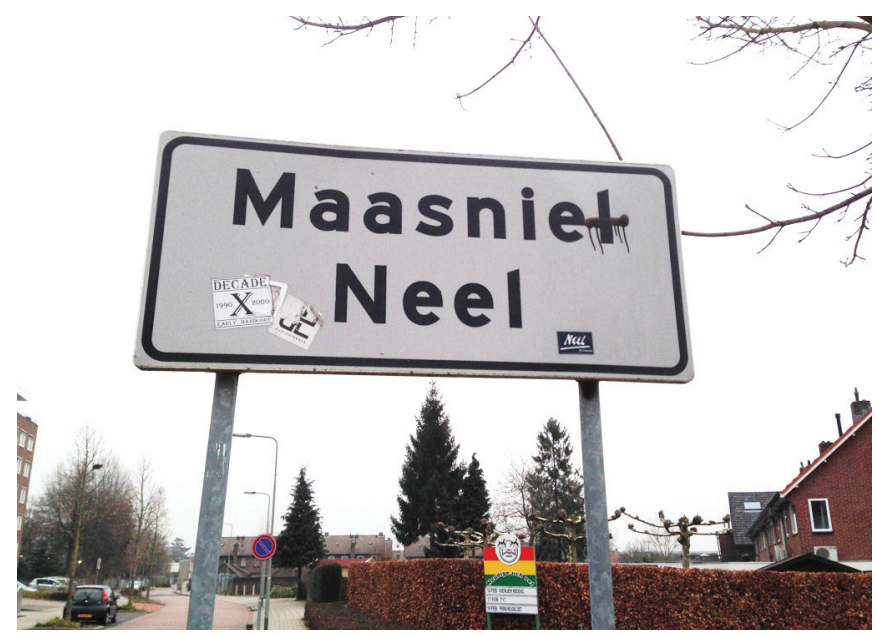

Historical-territorial narratives can be powerful tools in place-making processes and practices. These narratives help to imagine and produce a particular place as a bounded entity with specific coordinates on a map that is different and authentic from other places due to its history and geography (Beatley 2004: 53-55; Cresswell 1996; Savage et al. 2005). Historical accounts also often play an important role in the celebration of carnival, since carnival is a celebration that embodies memory, as Sanabria (2006: 326) explains:

Carnival celebrations either at the community or national level often function as a reminder - as a sort of memory history book - harking back to events and collective experiences deemed relevant for understanding the present. In this way, although played out in the present, Carnival has deep links with the past, but often these links are continuously reinterpreted to make sense of a changing present (ibid).

This idea that carnival celebration often goes back to historical events certainly holds true for De Katers carnival association and its embeddedness within the former village of Maasniel. This research case illustrates how historical-territorial narratives can be used in the current (re)production of place-making processes within carnival celebration and in dealing with dominant center-periphery dynamics.

In this chapter, I focus on De Katers' place-making practices, which produce Maasniel as a distinct place and employ historical-territorial narratives about the relations between Maasniel and Roermond. Section 4.1 explains how place-making practices 
help to produce, maintain, and challenge power relations between perceived centers and peripheries. I show what narratives and materials are used to give meaning to the place of Maasniel and its surroundings as a whole and De Katers carnival association in particular. Section 4.2 specifically focuses on the role of language practices in place-making processes.

\subsection{Carnivalesque place-making practices within center-periphery dynamics}

I argue that De Katers carnival association is one of the main institutions that still remembers and reproduces the tumultuous history between Maasniel and Roermond and Maasniel's identity as an independent municipality through place-making practices in which narratives, materials, and language (Section 4.2) are used in a playful and carnivalesque manner. Tuan (1991: 686) would argue that the efforts to display and reproduce Maasniel's history and distinctiveness compared to Roermond can be regarded as 'myths.' A myth has the power to transform abstract things 'out there' into real things that are important for the process of place-making. Myths are "foundational stories (...) that may strengthen a people's bond to place" (ibid). What is important is that the meaning of places should always be maintained and enhanced. This means that for a place to stay valuable to people, people should remember and reproduce these myths (ibid: 689). This can either be done through oral and informal language, such as calling Maasniel Nee/ in dialect, but also through literary works and materials. Beckers (2006: 202) similarly argues that Neel - as he remembers it from his childhood years - does not exist anymore; rather, it is a myth that exists in one's mind and helps to construct and legitimate a meaningful opposition, namely, between Maasniel and Roermond. These myths can be seen as essential for the carnival association of De Katers from Maasniel in order to distinguish its place as something unique, not only in opposition to Roermond but also to differentiate De Katers from other carnival associations, and to make distinctions within Maasniel itself. In the following section, I discuss the various place-making practices of De Katers on the basis of three center-periphery power relations that the practices seem to sustain and address: Maasniel vs. Roermond, Kern Maasniel vs. other areas within Maasniel, and De Katers vs. other carnival associations. Additionally, I show how people give shape to distinctions and power relations through their place-making practices within the particular locations where De Katers hold its events.

\section{Centralizing Maasniel and peripheralizing Roermond}

Well before Maasniel's actual incorporation into Roermond in 1959, De Katers introduced the association's song, Neel blief Neel (Maasniel remains Maasniel) in 1949:

Neel blief Neel, det klink al in 't rondj,

veer make 't gaer ein bietje bontj.

Karneval is veur plezeer,

det zinge veer, jao keer op keer.

Neel remains Neel, that's all around, we like to go a bit too far. 
Carnival is meant for fun,

we sing that, yes, time after time.

(Neel blief Neel, De Katers association's song from 1949)

Even though the lyrics of the song are not specifically aimed at protesting against annexation, with this song, De Katers showed support for the village wide anti-annexation protests in 1949 (Beckers 2006: 121; De Katers 1990). Nowadays the song is still played by the orchestra when De Katers members make their entrance during their own events or at receptions of other carnival associations. As such, it is a gentle reminder of the conviction that Neel remains Neel, even though it was taken over by Roermond more than 50 years ago.

My claim that De Katers carnival association is one of the few remaining institutions that stand firmly behind the Neel blief Neel message was also recognized by the chairman of the carnival association, Leon, and his advisor, Thei, during our first conversation:

\section{Extract 1}

Leon: 'T haet 't toch, ja, dink ich, toch waal vrie lang euver gedaon, of de gemeinsjap, om ongerdeel van Remunj te waere, ja. Maar ich dink noe, es se mien meining vreugs, dink ich, det 't grootste deil van de bevolking det Neel blief Neel logo neet meer zo eh...

It took, yes, I think, quite long for the community to become part of Remunj, yes. But I think now, if you want my opinion, I think that the biggest part of the population does not uh [stand behind] the Neel blief Neel ethos...

Thei: Nea jong det eh...

No, boy, that's...

Leon: Det is dink ich cultureel, oet de culturele vereniging dink ich, zeker waal That's, I think, cultural, from the cultural associations certainly yes.

Thei: Det is auch de hook wo 't nog oet kump.

That's also the area where it is still coming from.

(Conversation with Leon and Thei, October 1, 2012)

Both men argue that it is the cultural sector that still adheres to the Neel blief Neel ethos. In an interview with a local news website, Thei, who is also a songwriter, stresses the importance of carnival and carnival songs in putting Maasniel's origins on display: "Above all, a carnival song renders a community its own identity. Vastelaovend is the only time of the year in which we can display Maasniel's origins. A good song is able to express that perfectly." ${ }^{29}$ In this sense, the Neel blief Neel song offers inhabitants of Maasniel and members of De Katers a means to signal that they identify with Maasniel and the carnival association. Thei thus explicitly connects the community's identity to carnival, which is similar to what Da Matta (1991) has found in Brazil, where carnival contributes to the fostering of a collective sense of identity.

Maasniel's former village identity is often remembered during events at De Katers. During the $66^{\text {th }}$ anniversary reception at De Katers, the spokesman of the city center's home guard referred to Maasniel as being 'a neighborhood.' The monarch of De Katers

\footnotetext{
${ }^{29}$ I read the interview with Thei on http://roermond.gezien.nl/vastelaovend/hebben-nieuwe-generatie-creatieve-mensen-nodig.html. Unfortunately, this website is no longer available.
} 
took offense and immediately emphasized the strong community of Maasniel and that it was therefore not just a neighborhood of Roermond. ${ }^{30}$ This example demonstrates that the relationship between Maasniel and Roermond is a touchy subject, since the monarch immediately felt offended and reacted to the remark about Maasniel's being just a neighborhood. Through this territorial place-making practice, the monarch explicitly challenged and subverted dominant center-periphery power relations in a carnivalesque way. Such Bakhtinian subversions suspend and subvert hierarchies between people and allow for unconventional modes and 'carnivalesque mésalliances' (Bakhtin 1929: 122-123): Maasniel is not just part of Roermond, it stands on its own as a distinct place. Maasniel was centralized while Roermond was peripheralized, thus resisting dominant center-periphery power relations.

People at De Katers carnival association do not only use narratives, songs, and speeches to set Maasniel apart as a former village in opposition to Roermond; I also observed place-making practices that included concrete, physical objects. Within Maasniel's public space one can find two clearly visible statues of tomcats that refer to De Katers carnival association and the center-periphery opposition between Roermond and Maasniel; Figure 4.4 below depicts the older statue that stands on Betjesplein, Maasniel's central plaza.

Figure 4.4: Photo of tomcat statue on Betjesplein plaza in Maasniel (taken by the author, January 2 , 2015).

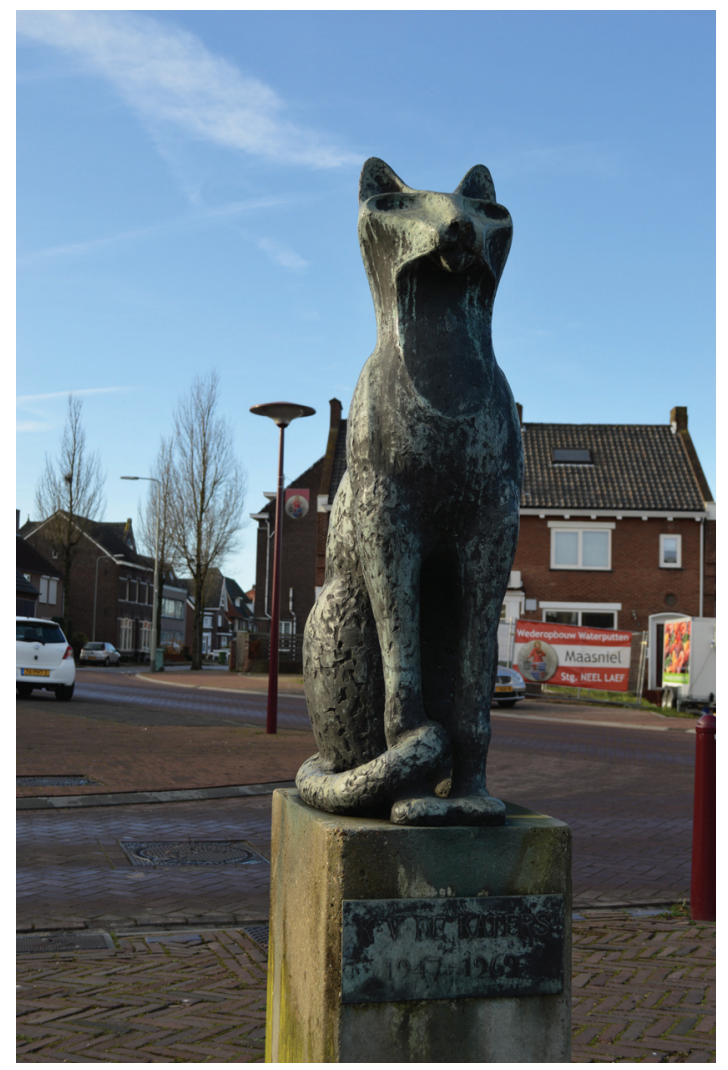

\footnotetext{
30 Field notes November 24, 2012.
} 
This medium-sized bronze statue of a tomcat was placed to honor the $2 \times 11\left(22^{\text {nd }}\right)$ anniversary of De Katers carnival association in 1969. The location of the tomcat statue is anything but random: the tomcat is ostentatiously placed with its back - "we prefer to say ass," a member informed me ${ }^{31}$ - towards the city center of Roermond. Another tomcat was especially designed and made in 2012 by the son of Chairman Leon to honor the $66^{\text {th }}$ anniversary of the carnival association. This tomcat stands on a roundabout at Maasniel's border, as shown in Figure 4.5 below:

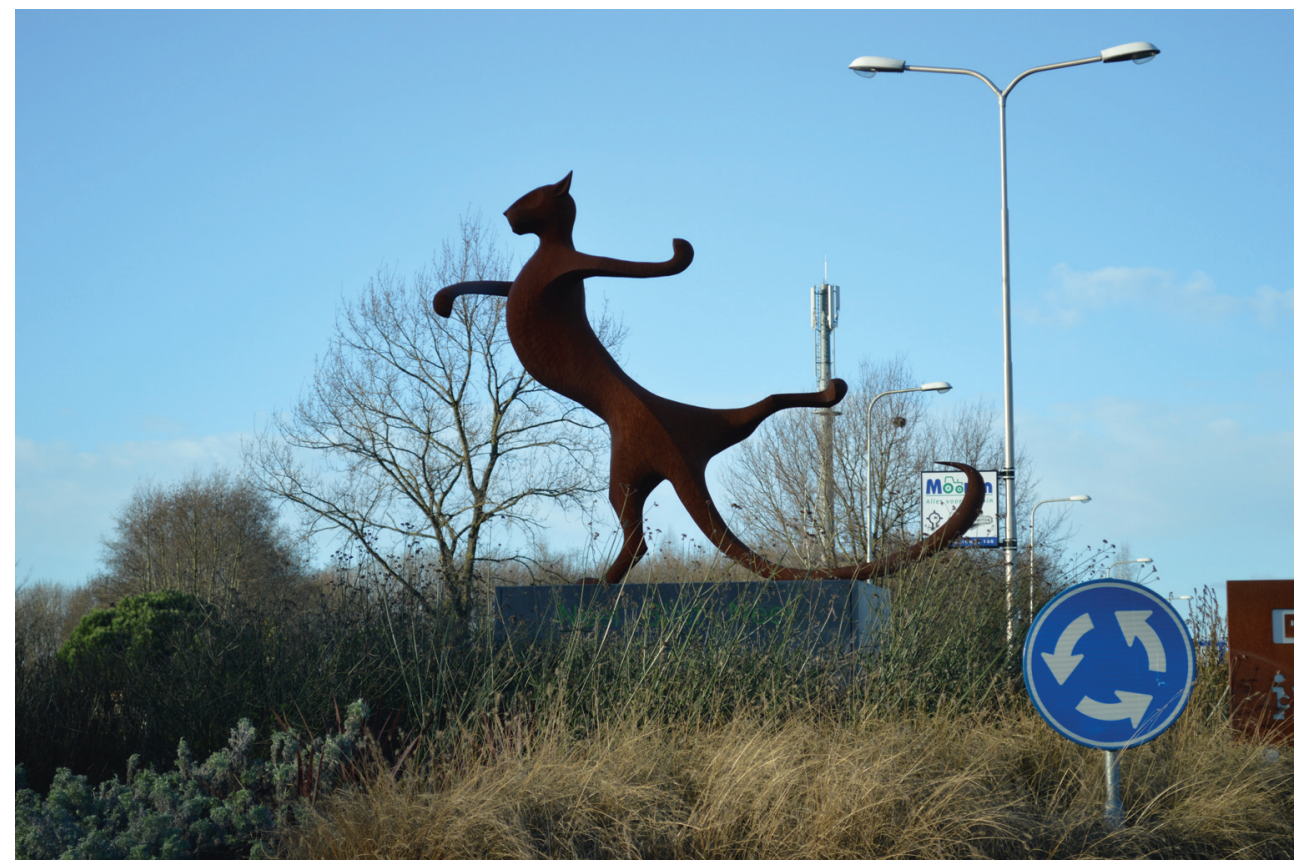

Figure 4.5: Photo of tomcat statue (designed and made by Bas Hamans) on roundabout in Maasniel (photo made by the author, January 2, 2015).

This three-meter high statue of a dancing cat was again strategically placed on a roundabout just on the edge of Maasniel's border. Instead of turning its back on Roermond, the cat now gives directions by pointing out which exit of the roundabout to take to go to Maasniel (Figure 4.5). The statues remind inhabitants and passers-by of the special status of the place of Maasniel within Roermond and possibly also strengthen people's bond to the place. Moreover, these statues can be seen as concrete ways to remember and reproduce Maasniel's history and former village identity and to centralize Maasniel over the city of Roermond, thereby challenging and resisting dominant center-periphery dynamics between the two. However, I found more examples of center-periphery dynamics during my fieldwork at De Katers carnival association.

Centralizing Kern Maasniel and peripheralizing other areas of Maasniel

\footnotetext{
31 Field notes, November 11, 2012.
} 
Within the administrative unit of the 'neighborhood' of Maasniel, as classified by the Municipality of Roermond (Districts and quarters in Roermond n.d.), there is a difference between the old village center that is called Kern Maasniel (Core Maasniel) and the remaining parts of Maasniel, as depicted in Figure 4.6 below:

Figure 4.6: Google Maps screenshot of the former village of Maasniel with the old village center, Kern Maasniel (Core Maasniel), highlighted in green (Image by Google Maps, courtesy of Google Maps).

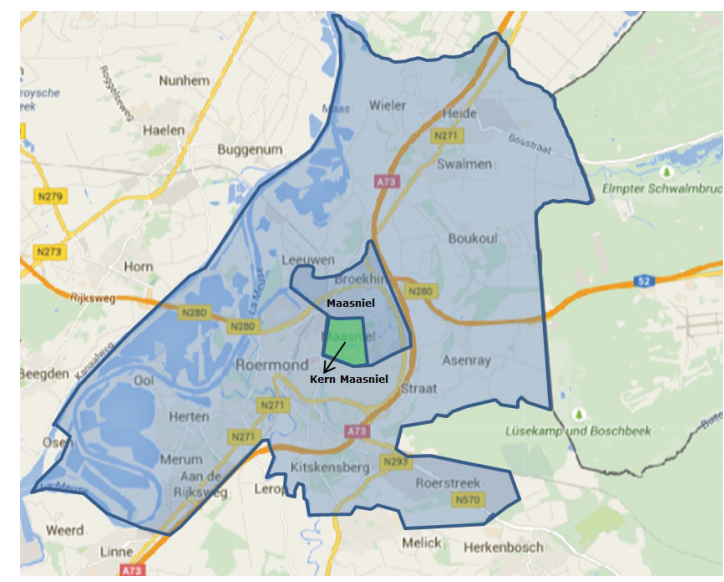

While following De Katers in their activities and events, I noticed that members of the association reproduced the differences between areas in Maasniel based on their belief that the promotion and remembrance of Maasniel as a former village with a special status within Roermond was mainly coming from the so-called Kern Maasniel area. The monarch of De Katers, Eric, confirmed this when I asked whether the extent to which people feel a mutual sense of belonging is highest in Maasniel, compared to other neighborhoods in Roermond:

\section{Extract 2}

Eric: Det is altied gewaes en det waas, ja, gechargeerd gezag, is aajer es Remunj (...) Det is det is, eh, jao det guf meer, eh, geveul dao bie dus jao en det angere det zien wieke die zeen oet de grondj gesjtamp in de loup der jaore, det zeen nuuje wieke. (...) Bie os bie Brikhove en bie, eh, de Wiejer, det zeen auch nuuje wieke en die sjloete zich neet gauw aan bie De Katers asse dan zaes van Neel blief Neel det is ech 't geveul van de aaje durpskern en neet zo zeer de nuuje.

It has always been this way and it is, yes, to say it exaggeratedly, it's older than Remunj (...) It [Neel] gives more, uh, feeling, so, yes, and the others that are neighborhoods, that have been erected in the, over the years, those are new neighborhoods. (...) With us [in Neel], Brikhove and, uh, De Wiejer are also new neighborhoods, and they do not join De Katers as quickly. If you say then Neel blief Neel, that's really the feeling of the old village center and not really of the new ones. (Interview with Monarch Eric, November 7, 2014) $)^{32}$

\footnotetext{
${ }^{32}$ Brikhoven and De Wijher (Brikhove and De Wiejer in dialect) are newer parts of Maasniel that were built in the 1990s.
} 
In this quote, Monarch Eric makes it clear that people in Maasniel affiliate more to Maasniel than people living in Roermond affiliate to Roermond. More important, Eric emphasizes that people inhabiting the old village center of Kern Maasnie/ in particular seem to represent and reproduce the Neel blief Neel feeling the most. In contrast, members living in newer parts of Maasniel are not as quick to join the carnival association of De Katers to promote that feeling.

This perceived difference between Kern Maasniel and the rest of Maasniel also became clear during the pub tour on the first day of the carnival season (November 11, 2012). The pub tour started in the association's main residence café, De Ster (The Star), also referred to as the Kater-pelies (De Katers palace), where most main events are organized. After the official opening on the plaza, the pub tour continued along to different cafés in order to maintain good relationships with the owners and the entire community of Maasniel. Yet all of these cafés were located within Kern Maasniel.

Similarly, when I helped the carnival association deliver its magazine to members, it was remarkable that we did not go to the areas where social housing buildings of Maasniel are located and where the most people from so-called non-western backgrounds live. While delivering the magazines, it became clear that most members of the association lived either in Kern Maasniel or in bigger houses in other parts of Maasniel.

It is for these reasons that I argue that De Katers reproduces and imagines Kern Maasniel as the area in Maasniel where the village identity of Maasniel is remembered the most. The practices at De Katers carnival association seem to make distinctions within Maasniel between Kern Maasniel, where the Neel blief Neel feeling is higher than in other parts of Maasniel. As such, Kern Maasniel is centralized, while other parts of Maasniel are peripheralized as places where people do not really affiliate with De Katers and lack the Neel blief Neel spirit. De Katers thus produces distinct places within Maasniel through place-making processes and practices. Moreover, the research case of De Katers shows how power oppositions that are salient at one societal level may recur within a more local context: the center-periphery dynamics between the perceived center of Roermond and the perceived periphery of Maasniel recur on a more local level (cf. Eckert 2011; Irvine and Gal 2000) within the confines of Maasniel itself, where De Katers seems to distinguish between the Kern Maasniel area that actively reproduces the Neel blief Neel feeling and other areas of Maasniel that are believed to lack this feeling. This production of distinct places within Maasniel through place-making practices also puts forward ideas about politics of (un)belonging (cf. Antonsich 2010; Christensen 2009; Cresswell 1996; Yuval-Davis 2006): the Kern Maasniel area is perceived to be in place at De Katers carnival association while other areas of Maasniel are perceived to be out of place.

\section{Centralizing De Katers and peripheralizing other carnival associations}

Other instances of center-periphery dynamics were found in the relations that De Katers carnival association had with other carnival associations. Carnival celebrations within carnival associations depend on the interactions with other carnival associations, since it is through these interactions that associations are able to continuously delineate their distinctiveness visà-vis each other. This can be done through traditions, rituals, songs, attributes, and clothing. At De Katers I observed that clothing played a key role in distinguishing it from other associations. This showed from Wil's (at that time a member of the council of eleven and former prince of 2004) explanation when we were looking at some princes who visited during the 
carnival orchestra's event at De Katers. ${ }^{33}$ During the event, the $2012-2013$ season's Prince Tim I of De Katers was standing next to the prince of carnival association De Nachtegalen (The Nightingales) from the village of Asenray, a village that is now part of Roermond, formerly a hamlet of the Municipality of Maasniel (see Figure 4.2). While standing behind the princes, Wil pointed out the differences to me. The prince of De Katers wore black lace-ups, while the prince of De Nachtegalen wore boots. Princes at De Katers are discouraged from wearing leather boots, as most princes in the Roermond area do. Many members of the association informed me that they thought boots were not as 'decent' as black lace-up shoes. Moreover, the prince of De Katers wore short pants, and his cape was not overly decorated, whereas the prince of De Nachtegalen wore longer pants, and his cape was trimmed with fur and covered with frills and diamonds. It is here where the relevance of the deployment of material cultural resources in constructing politics of belonging becomes particularly clear (cf. Cornips and De Rooij 2015): the place-making practices of De Katers by which they distinguish themselves from other carnival associations show who and what (clothing in this case) are perceived to be in place and who and what are perceived to be out of place.

The relations of De Katers carnival association and D'n Uul carnival association from the city center of Roermond deserve special attention when discussing how De Katers distinguishes itself from other associations. D'n Uul carnival association is affiliated with the city center of Roermond. Given the tumultuous history between Maasniel and Roermond, D'n Uul carnival association's affiliation with the city center of Roermond lends a special significance to the relations between De Katers and D'n Uul. Since the 'annexation,' members of De Katers (re)produce an opposition between Maasniel and Roermond and, particularly, between their own association and the D'n Uul carnival association. This shows that center-periphery dynamics associated with one level (Maasniel vs. Roermond) can be reproduced at the level of the carnival associations themselves.

Wim, at that time an 82-year-old saxophonist in De Katers' orchestra and former prince of 1963, vividly remembered the times when relations between the carnival associations of De Katers and D'n Uul were hostile. During our interview, he recounted:

\section{Extract 3}

Wim: When I was prince in 1963, I took part in the parade in Roermond on a camel. The members of the council of eleven and the orchestra were all dressed as Arabs. Only I was dressed in my prince's suit. We won the first prize, but in the evening we heard that the prize was withdrawn since we weren't official enough. The committee of the parade, D'n Uul, made that decision. After that, De Katers did not take part in Roermond's parades for three years. (Interview with Wim, March 15, 2013) ${ }^{34}$

Nowadays the rivalry between De Katers and D'n Uul has weakened, although both associations still make 'serious jokes' about one another during their receptions. A case in point was the event for various carnival associations' prince orchestras (Recordings, No-

\footnotetext{
33 Field notes, November 23, 2012.

${ }^{34}$ Wim's quote is compiled from transcriptions of the interview I had with him. His description of his princeship and the parade in the city center of Roermond took too long and included many digressions to other stories, which is why I decided not to provide the full transcript verbatim.
} 
vember 23, 2012), during which the chairman of D'n Uul congratulated De Katers on their $66^{\text {th }}$ anniversary and specially honored Chairman Leon for his devotion to the association by presenting him with an oak statue of $D^{\prime} n$ Uul. ${ }^{35}$ In the accompanying speech, the chairman of D'n Uul mentioned Leon's connection to De Katers and vice versa and that he appreciated how De Katers and D'n Uul are increasingly cooperating together. ${ }^{36}$ Immediately after this statement, a man in the crowd yelled "hey hey hey" to display his discontent with it (Recordings, November 23, 2012). The chairman of D'n Uul then pointed at a box hanging on the wall, over the bar, where a big tomcat and a little owl stand next to each other:

\section{Extract 4}

Chairman: Ich zeen dao bie dae kater zomaar de uul sjtaon, lekker same werrem in ein keske. De verhoudinge, dao kinse om twiste, maar alleh. Het feit detse dao zo fijn bie mekaar sjtaon, is toch sjoon.

I see that the tomcat stands with the owl, nicely together, warm in a little box. The proportions, you can argue about it, but okay. The fact that they are so nicely standing next to each other, is nevertheless beautiful. (Recordings, chairman of city center carnival association D'n Uul during anniversary reception, November 24, 2012)

After Leon received the oak statue from the D'n Uul chairman, he quickly removed himself from center stage and joined the council members and me in the audience. He explained, "I don't need all this. The people who are now leading D'n Uul are from Neel, so that's why they are here today." I commented, "Yes, I already heard that De Katers have already infiltrated D'n Uul!" Leon laughed, "Yes, the coup is nearly complete! No, that's tomfoolery" (Field notes, November 24, 2012). I often heard this emphasis on the humorous nature of comments about the rivalry between De Katers and D'n Uul, which shows that members of De Katers perceive the rivalry as an ever-recurring fun gag that nevertheless highlights and safeguards the borders of Maasniel, hence, a form of place-making. The carnival associations of De Katers and $D^{\prime} n$ Uul function as symbolic representations of the dominant center-periphery relations between Maasniel and Roermond. As such, the associations reproduce the recursion of center-periphery oppositions salient at a particular level at an even more local level, namely, the level of carnival associations. Yet De Katers carnival association actively challenges and resists the center-periphery dynamic of Maasniel vs. Roermond in a carnivalesque manner by centralizing Maasniel and De Katers and peripheralizing Roermond and $D^{\prime} n$ Uul. There seems to be a paradox in this carnival domain. De Katers members continuously commit themselves to safeguarding the borders of Maasniel and De Katers in opposition to Roermond and D'n Uul yet, at the same time, they are very much dependent on the existence of both Roermond and D'n Uul to be able to do so. In other words, the carnival association of De Katers simply requires the existence of a significant other as a counterbalance to its own place-making practices - a statement that members of De Katers would obviously protest against.

\footnotetext{
35 Since the D'n Uul carnival association was unable to come to the next day's anniversary reception, its members used the prince orchestras event to congratulate De Katers and hand out presents.

${ }^{36}$ Original text: "Waat ich auch sjoon vinj, is det de Katers en D'n Uul sjteeds dichter kroepe."
} 
I have hitherto pointed out how place-making practices at De Katers carnival association produced Maasniel as distinct from other places and De Katers as distinct from other carnival associations. The members of the carnival associations also engaged in place-making practices that produced distinctions within the locations where De Katers events and meetings were held. A telling example of this was the board meeting held at the house of De Katers Chairman Leon. The following vignette exemplifies that Leon can best be described as a De Katers-enthusiast:

On a cold December night I leave my bike on the driveway of Leon's house. A small statue of a tomcat welcomes me at the porch. Affixed to the wall of the house, I see the huge plaque of De Katers that Leon received to honor his efforts for the association. "Hi, Lotte, come in!" Leon looks excited, even though this must be the umpteenth time that he is hosting a board meeting. While hanging up my coat, I spot tomcats all over the place. I am already walking towards the living room, but Leon guides me to the basement: "The board meetings take place in the basement, so that anything impertinent is kept underground," he says with a mysterious smile. After having descended the staircase, I find myself in a brightly lit basement that is completely devoted to the storing and display of De Katers merchandise, promotion material, and posters from bygone days. A large round of tables and chairs transforms the basement into a meeting room, although the bar in the back of the room reminds one of wild De Katers after-parties that must have taken place here. While board members enter and greet each other and me, Leon makes sure there is enough to drink and snack on. When he arrives with the coffee, I am not really surprised that it is served in a tomcat-shaped flask.

(Field notes, December 10, 2012)

The statue and plaque at the porch, the many small tomcats around the whole house, the merchandise, and the flask are all materials that Chairman Leon intentionally bought, hung up, and used for that specific night due to their connection with the carnival association of De Katers and, because of that, with the place of Maasniel. Within this context, all these tomcat-related accessories have a specific function - in the words of Bienia (2016), the materials are actors - in place-making practices that give meaning to the place of Maasniel as being a former village that stands apart from the city of Roermond. Moreover, the materials and practices represent and reproduce Leon's own place-belongingness (cf. Antonsich 2010) to Maasniel and feelings of belonging to De Katers - there can be no mistake as to which carnival association and area in Roermond he is affiliated.

Besides these more personal place-making practices Leon used to decorate his own house to express his feelings of belonging, I also observed place-making practices that produced gendered power relations within the locations where De Katers events were held. Although carnival is celebrated by all genders, carnival celebration in associations can be quite gendered (see also Wijers 1995 on this topic): in some associations, only men can become a prince, a member of the council of eleven or a monarch. At De Katers carnival association, men and women are separated in most departments (with exception of the orchestra and youth department) and, with the exception of the women's evening, there is no mention of women on the events schedule (see Appendix B). In Chapter 3, I already 
pointed out how gender played a role in carrying out my ethnographic fieldwork within a mainly male-centered research location. I regard the ways that women were part of the carnival celebration practices at De Katers as a way of place-making, since gender often played an important role in the place-making practices and the positioning of women within event locations. The remark on the very first day of fieldwork ("the women stand over there, you know") already hinted at this (see Chapter 3, Section 3.2).

During De Katers events, the different departments usually stood together. The map in Figure 4.7 below depicts how different groups were positioned during the prince announcement event at De Katers residence café De Ster:

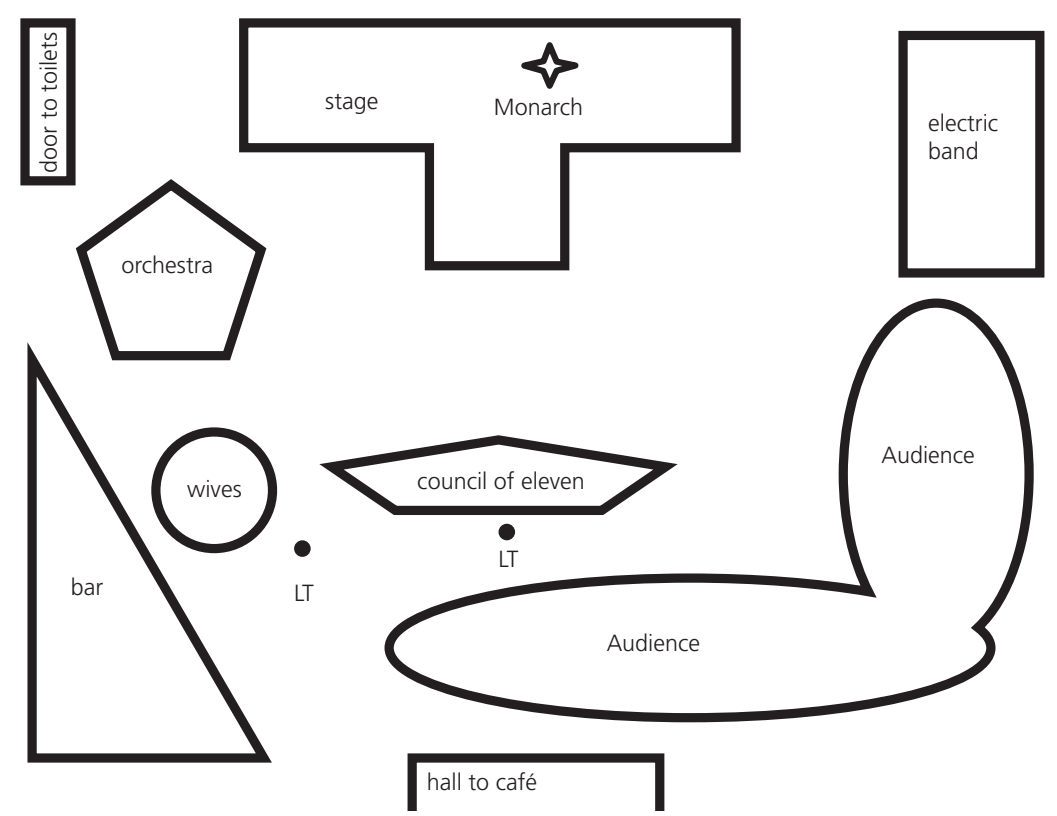

Figure 4.7: Map of the hall at De Katers residence café De Ster during the prince announcement event.

During the prince announcement, it was striking to see how the different departments of the association stood together during the evening. The group of women, consisting of the wives of the council of eleven members, was strategically positioned close to the bar and close to the members of the council of eleven. Both groups never really mingled, only occasionally asking for or getting things from each other: I witnessed women going to the men's group to get money and men going to the women to get help with pinning up medals or other carnival souvenirs that they got from the prince or visiting carnival associations. Such practices reproduced gendered patterns within the carnival association of De Katers.

One particular occasion very much highlighted the unequal position of women within the carnival association of De Katers. Just before the actual days of carnival, I emailed Chairman Leon to ask whether I could join them on their vessel during the parade in the city center of Roermond. After a few days, I received a positive response. So, during the carnival days, I was looking forward to standing on the vessel of De Katers in the big parade of Roermond: 
In the street where the vessels and groups for the parade in Maasniel are getting in line, I encounter Leon wearing a wig and standing next to a baby buggy filled with dolls. He holds a piece of cardboard that says 'from now on, I watch the small ones': a direct hint about the end of this chairmanship and future grandfathership. I ask him at what time I should meet them for the parade in Roermond tomorrow afternoon. "12:30 p.m. at café De Pauw. It is a real exception to have a woman on the vessel, so you should appreciate it," he says strictly.

Monday afternoon - which feels like morning during these carnival days - I watch all the vessels of the city center's parade gather. De Katers' vessel arrives and I see that the wives of the council of eleven are getting off - they used the vessel as transportation from Maasniel to Roermond. Their act is called Sjale vaegers (which literally means 'cross-eyed sweepers,' referring to someone who is idiotic or retarded), and they are all dressed in bright blue and carry brooms to portray a vaeger, someone who is sweeping. After a quick drink in the café, the monarch, prince, his guards, and some members of the council get on the vessel. As do I, leaving the women of the council of eleven behind the vessel, walking. (Fieldnotes, February 10 and 11, 2013, see Figure 4.8)

Figure 4.8: Photo of the author standing on the vessel among De Katers male members while handing out sweets during the city center parade of Roermond (taken by Sanne Thissen, February 11, 2013).

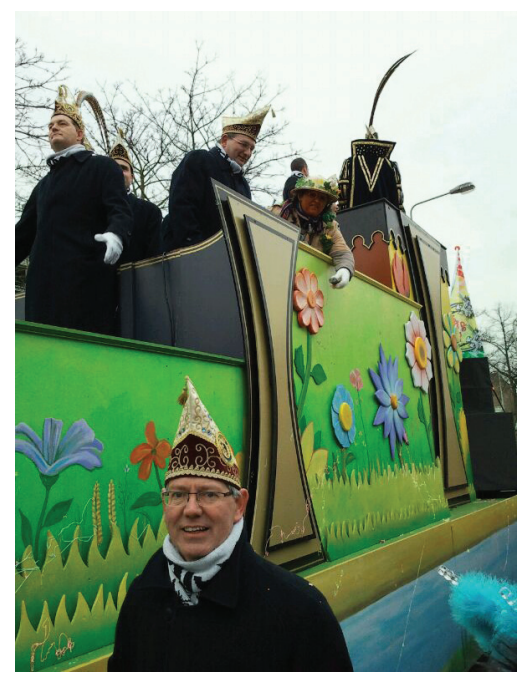

As Chairman Leon pointed out, it was highly exceptional for me, a woman, to be on the vessel with the men. During the parade, the men tested my toughness in drinking (by offering me all sorts of liquor) and throwing around sweets while sometimes making remarks about my extraordinary presence on the vessel.

These observations and experiences underline how gender plays a role in placemaking practices within the locations that De Katers visit (café De Ster, the parade) and the ways that these places are divided up and given meaning; the women stand over 'there' and the parade vessel is for men only. 


\title{
4.2 Linguistic place-making practices: assembling spatial repertoires
}

\author{
The taken-for-granted use of dialect during carnival celebration at De Katers
}

While dialects in Limburg are spoken throughout the year, their prominence increases during carnival celebration, something that resonates with Bakhtin's idea of the carnivalesque (1984), when 'normal' hierarchies are suspended and new modes of behavior are possible. This resembles the way that Sámi languages are used in Finnish tourism, through which dominant and established interaction orders, rules and norms are subverted (Pietikäinen 2015: 221). During my interview with Wim, a saxophonist in De Katers' orchestra, he first emphasized the firm connection between carnival celebration and Limburg:

\section{Extract $5 a$}

Wim: Det is de lol dae se d'raan höbs en de saamhorigheid van de miense eigelik hè, maar 't is, 't is geweun gebonje eigelik hie aan 't Limburgse hè?

[Carnival] is about the fun of it and the togetherness of the people actually, but it is, it is simply connected to here, the Limburgian right?

(Interview with Wim, March 15, 2013, my emphasis)

After Wim firmly connected carnival celebration to "here, the Limburgian," I asked him whether one could celebrate carnival in Limburg without speaking a dialect. He responded:

\section{Extract $5 b$}

Wim: Det is moeilijk [lacht] det is moeilijk jao, den kriegse dae Hollandse kal weer hè. Jao, det is hie nörges, doe mos gewoon plat spraeke, det is juus eh, det is euveraal hè. Kom maar 's in Kerkrooj, kom maar 's in Mestreech, kom maar 's in Heerle, allemoal dialek, die gaon gein Hollands kalle hè, mit carnaval, worom? Woh, as d'r 'ne Hollenjer bie sjteit, mot 'r zich maar aanpasse, ja zo zeen ich 't.

That is difficult [laughs], that is difficult, yes, then you get that Hollands (Hollandic) talk again right. Yes, you don't have that here, you just have to speak plat. That is essential, uh, it is everywhere right. Go to Kerkrade, go to Maastricht, go to Heerlen, all is in dialect. They won't talk Hollands (Hollandic) during carnival, why would they? Right, if there is a Hollander standing next to them, then he should adapt, yes, that's how I see it.

(Interview with Wim, March 15, 2013)

Apart from what seemed to Wim to be the obvious link between carnival celebration and Limburg, the use of local dialects seemed to play an important role as well in carnival celebration practices (Cornips \& De Rooij 2015; Wijers 1995). Wim clearly made a connection between carnival and talking plat (another word to refer to dialect) as an important requirement to celebrate it. According to him, speaking Dutch has no function during carnival: if a Hollander (someone from the Randstad area or from a non-carnival celebrating area outside the south of the Netherlands) joins in, he is expected to adapt to the situation. The label 'plat' gives the use of dialect a special connotation depending on 
who is using and interpreting the label. As such, plat can refer to a language that provides familiarity and a closer relationship to the people you talk plat with. Wim referred to this interpretation of plat by stating "you just have to speak plat" in comparison with Hollands (Hollandic), which probably referred to a variant of Dutch spoken 'above the big rivers,' usually referred to as dividing the Netherlands into northern Protestant and southern Catholic parts. Wim's use of "just" emphasized the self-evident use of plat in the carnival association and the closeness that it offers when a group of people can "just" use it, without questioning or discussing it beforehand. A more negative interpretation of plat would be that dialect indexes a way of speaking that is uneducated, rude, impolite, and boorish (Hagen and Giesbers 1988; Mathijsen 2011: 19-20). As with all language attitudes and ideologies, the salient interpretation understandably depends on the interpreter and the situation. The label 'plat' will be revisited in Chapter 5, where I will further elaborate on the almost taken-for-granted use of dialect during a carnival event at De Katers.

\section{Spatial repertoires in use at De Katers}

After Wim's statement about the use of Dutch during carnival, it may come as no surprise that members of De Katers primarily used dialect registers to talk to each other in both staged and off-stage interactions. Yet, as Chapter 5 will point out, this dialect-routine can be exposed and broken when people who are considered to be 'strangers' unable to speak and understand dialect enter the carnival association. The fact that members exclusively addressed me in Dutch during the first weeks of fieldwork, while continuing to use dialect among each other, initially gave me the feeling of being 'strange' in this place.

In Limburg, the connection between tradition and language is even more striking in carnival songs that are sung in dialect. When the popularity of Dutch carnival songs increased in the 1970s, owners of cafés encouraged each other to play dialect carnival songs exclusively as an attempt to stop 'the Dutchification' of vastelaovend in which Dutch carnival songs became popular (Wijers 1995: 38-39). Furthermore, in 1977 the regional song contest, Limburgs Vastelaovesleedjes Konkoers (Limburg's Carnival Song Contest), was specifically organized to promote dialect carnival songs (ibid). Nowadays most songs are performed in dialect, and local and regional carnival song contests are quite popular. Moreover, dialect writing in the public sphere increases during the carnival period, thereby shaping the linguistic landscape of many cities and villages within Limburg during carnival days, when dialect writing is increasingly found in the streets.

\section{Displaying spatial repertoires in the linguistic landscape of De Katers}

The use of dialect in interactions is only one aspect of the spatial repertoires of De Katers in Maasniel. Another aspect consists of the display of spatial repertoires in carnival celebration at De Katers carnival association. The paradigm of 'linguistic landscape' has gained popularity over the last decades in sociolinguistics. Landry and Bourhis (1997: 25) were among the first researchers to use the term that included the examination of 'the language of public road signs, advertising billboards, street names, place names, commercial shop signs, and public signs on government buildings.' These signs make up the so-called linguistic landscape of a particular territory. By studying such linguistic landscapes, Landry and Bourhis aimed to reveal the ethnolinguistic vitality of particular languages of competing ethnolinguistic groups in multilingual settings. Later studies (Gorter 2006; Shohamy et al. 2010) 
focused on content and the social meaning of language display in public spheres rather than measuring ethnolinguistic vitality. This shift resulted in analyzing the impact of language display on social realities and on the ways that we experience our surroundings, thereby undoing fixed connections between language display and ethnicity. In this way, linguistic landscaping in a particular location enables us to understand, in a bottom-up manner without presupposed ethnic categories, how a place is produced and perceived by the people that inhabit it. Moreover, linguistic landscaping provides insights into what behavior is perceived as in place and out of place (cf. Cresswell 1996), which makes the paradigm highly suitable for the study of place-making. Yet where the linguistic landscape paradigm originally only examined the display of linguistic signs in particular (public) places, I argue that actual language practices of people contribute equally to the construction of a particular linguistic landscape. It is in dialogue with these actual language practices that the display of linguistic forms is articulated and vice versa. Therefore, I follow Pennycook and Otsuji (2014a) by expanding the linguistic landscape paradigm by using the notion of spatial repertoires that includes both the display as well as the use of linguistic forms in interactions.

In order to gain insight into how place-making processes were construed through the use of language within De Katers carnival association, I examined the spatial repertoires of the association's environment (Maasniel as a whole and residence café De Ster in particular). During events at the carnival association of De Katers, I observed many written signs that almost exclusively used dialect registers. The announcement bulletin boards of De Katers stood out most when looking at the display of linguistic forms, since it was here where the link between place-making and language was made explicit through the attachment of linguistic forms and meaning to particular places. The bulletin boards were put up from November 11 onwards and announced the events organized at the carnival association (see Figure 4.9). The boards were also used, in December, when there were no events, to wish passers-by happy holidays during Christmas (see Figure 4.10). By placing these boards at the borders of Maasniel, De Katers highlighted the boundaries of 'their village,' thereby engaging in a place-making process that seemed to say: 'This is Maasniel, De Katers' place.' At the same time, the boards defined the linguistic landscape or spatial repertoire, since the exclusive use of dialect for their bulletin boards conveyed the idea that there was a strong link between De Katers carnival association, which belongs to Maasniel, and the use of dialect.

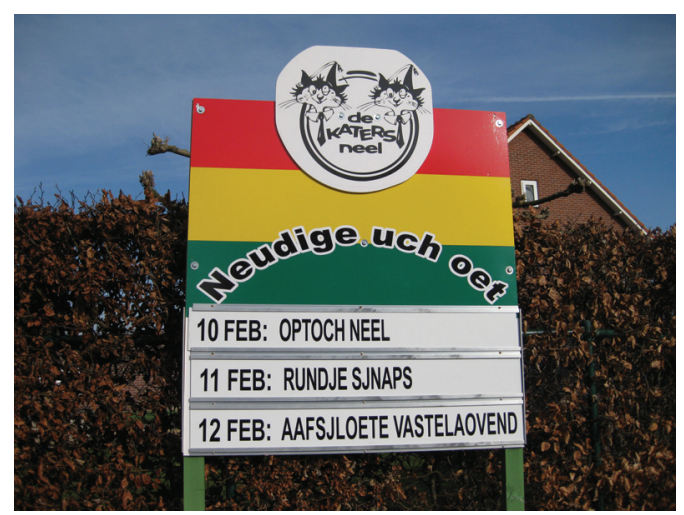

Figure 4.9 Bulletin board via which De Katers invite people to attend their events (photo taken by the author, February 10, 2013).

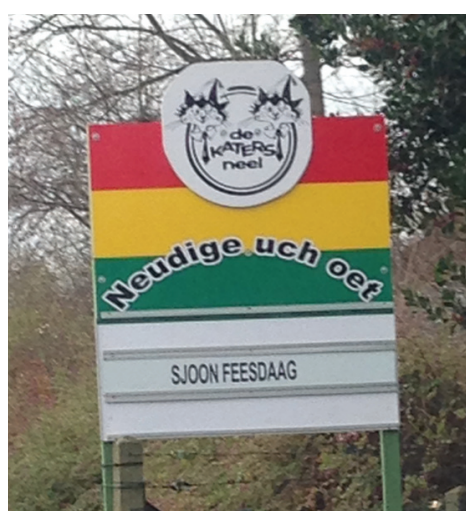

Figure 4.10: Bulletin board wishing people happy holidays (photo taken by the author, December 26, 2013). 
Two other examples also illustrate the display of written dialect signs within the spatial repertoire of De Katers in Maasniel. During the season, the youth prince and his guards were driven around in an antique Fiat 500 that was decorated with a photo of the youth prince and his guards and his slogan, mit eine breije lach, same ónger de Katervlag! (with a big smile, together under De Katers flag), see Figure 4.11:

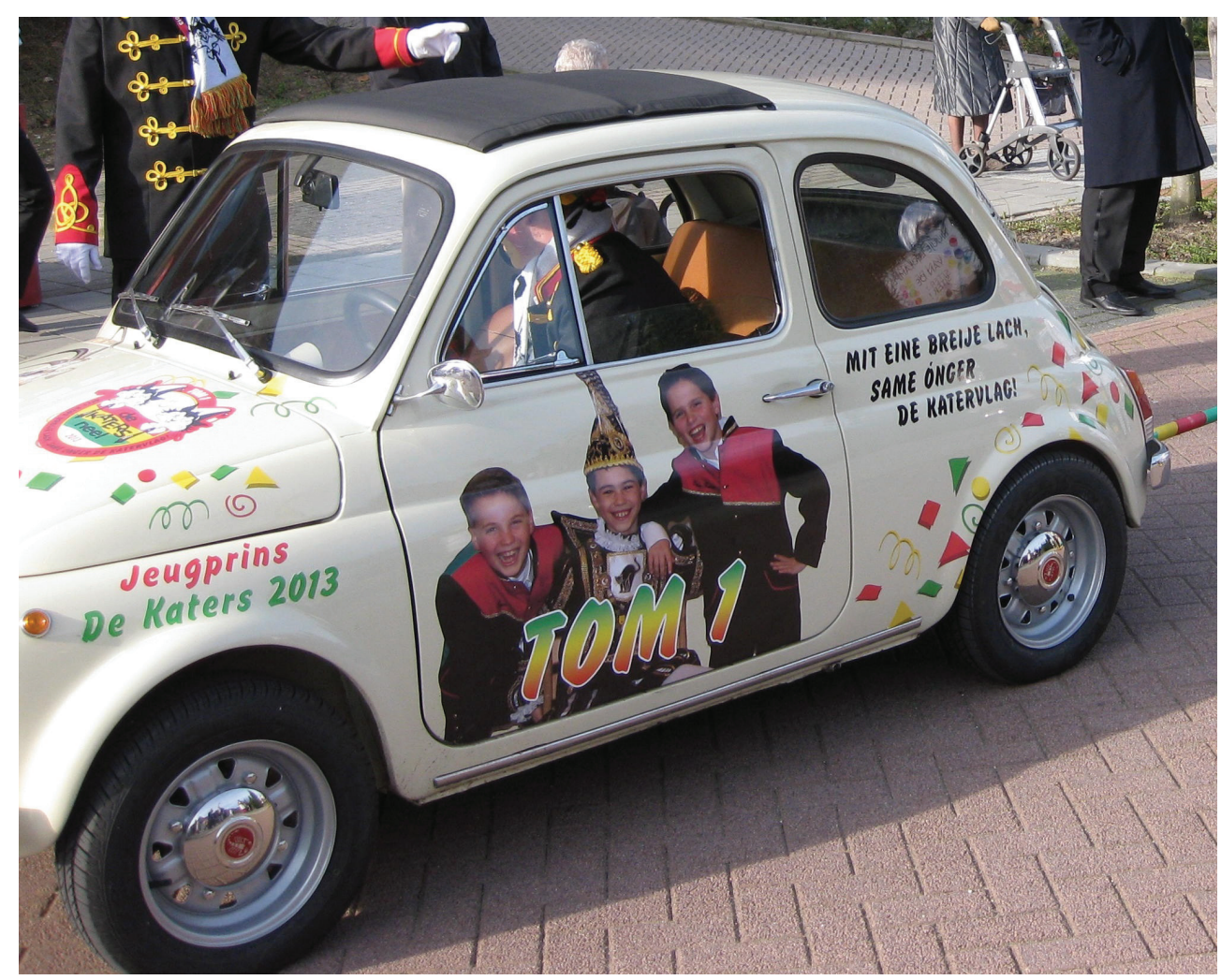

Figure 4.11: The youth prince's car during the parade in Maasniel (photo taken by the author, February 10, 2013).

Apart from this decorated car, the youth prince's home was also decorated with flags and a balloon saying: "Pssst... hiej sjleupt de jeugprins" ("Shh... the youth prince is sleeping here!") (see Figure 4.12). In this way, the neighborhood was informed that the young royal highness of De Katers lived here. As with the bulletin boards, these examples emphasized a link between dialect use and the carnival association from Maasniel. 
Figure 4.12: The youth prince's home in Maasniel is decorated with De Katers flags and a balloon saying: 'Shh, the youth prince is sleeping here!' (found on De Katers' website).

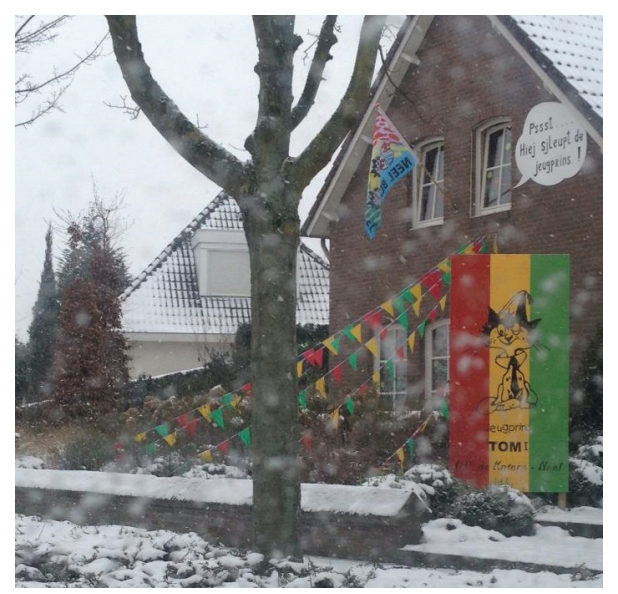

The prominence of dialect in the spatial repertoire of De Katers was also revealed during their events. For the opening of the carnival season, a billboard was put up on the central plaza that depicted two painted tomcats and the logos of De Katers and Maasniel (see Figure 4.13). The billboard showed the phrase dunnelvdevandunnelvde (the-eleventhof-the-eleventh) in dialect, referring to the carnival season's opening date of November 11.

Figure 4.13: Billboard during the opening of carnival season (photo taken by the author, November 11, 2012).

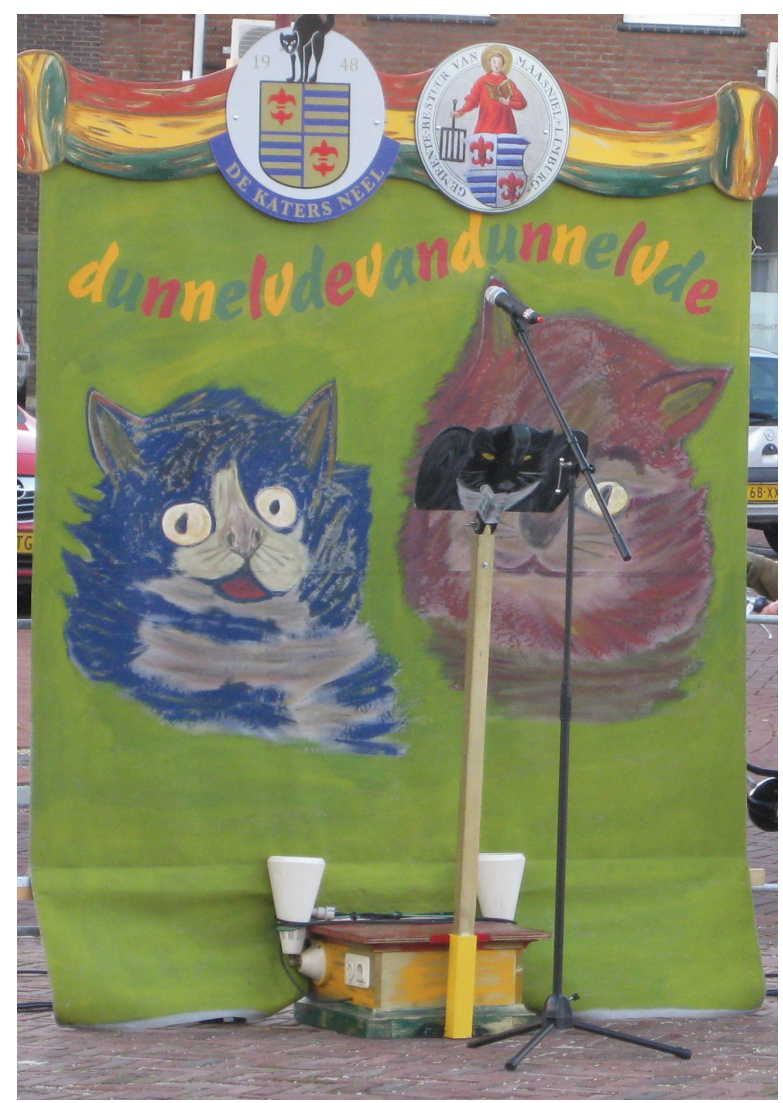


I observed another example of written dialect at De Katers during the announcement of the youth prince. While the youth prince was still hidden in a kind of tent, he gave answers to questions that were posed by the youth council of eleven via written signs. For the question "who is the funniest at home," posed in dialect, the youth prince showed the answer "mien zöster," which is dialect for 'my sister' (see Figure 4.14). The spatial repertoire employed during events of De Katers thus mostly consisted of signs written in dialect registers.

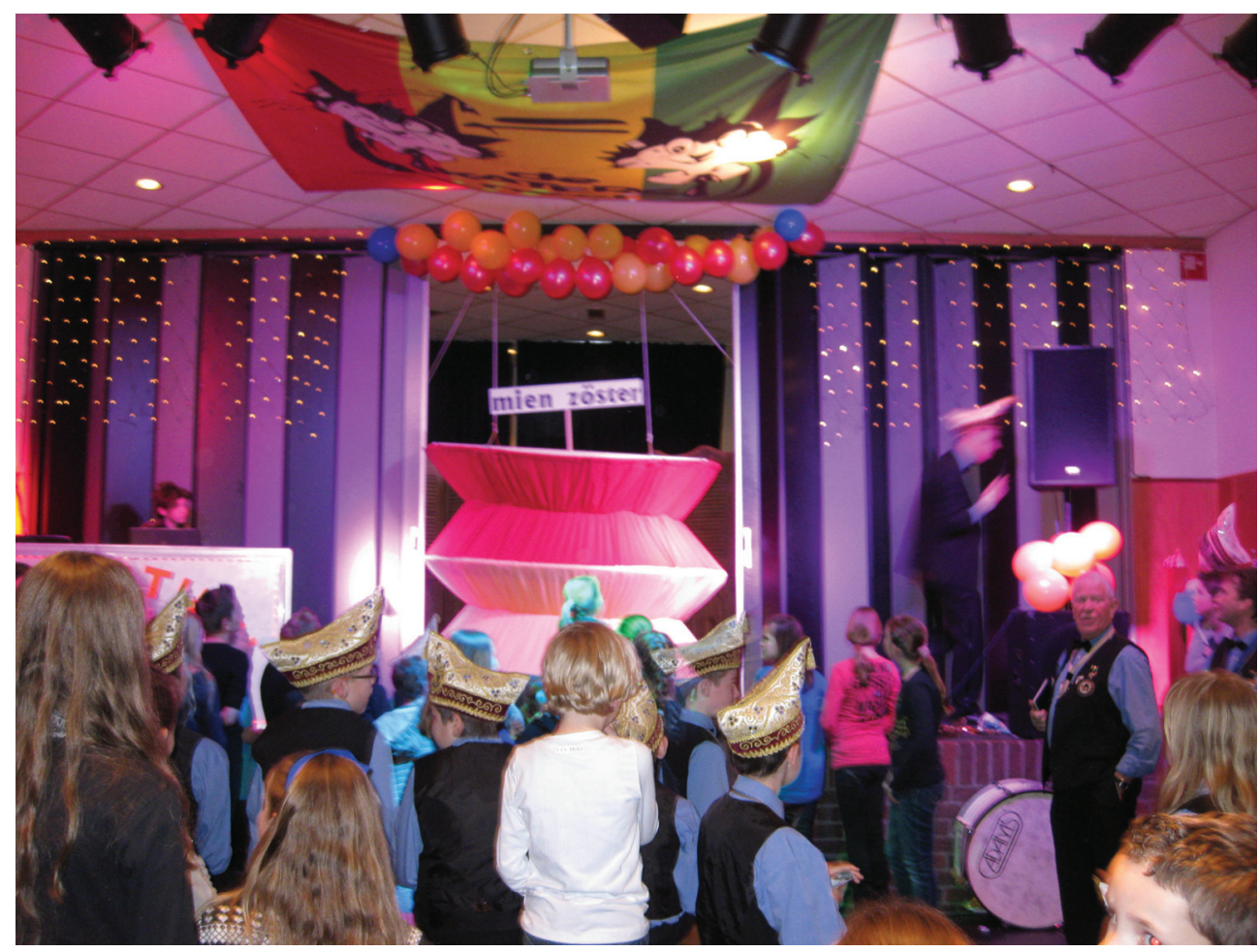

Figure 4.14: The future youth prince showing the sign mien zöster (my sister) during his announcement (photo taken by the author, January, 2013).

As well as these written dialect signs found in the environment and at De Katers events, the KlassjeNee/ magazine is written entirely in dialect register. The magazine is an important medium during carnival and is distributed by the monarch, adult and youth prince, council of eleven, and the orchestra a few weeks before the actual days of carnival. Figure 4.15 shows Prince Tim I and Youth Prince Tom I on the cover of the KlassjeNeel edition marking De Katers' 2012-2013 66th anniversary season.

The KlassjeNeel magazine includes information about that season's princes, past and coming season events, as well as general news and jokes. Moreover, KlassjeNeel includes many advertisements that are necessary to cover the printing costs of the magazine. The pieces I wrote in dialect for KlassjeNeel magazine were drastically edited with respect to a 'proper' dialect spelling and correction for use of 'authentic' dialect and carnivalesque words instead of Dutch, English or, if not even worse, scientific phrases and words. 
Figure 4.15: Scan of the cover of De Katers KlassjeNeel magazine from the 2012-2013 season.

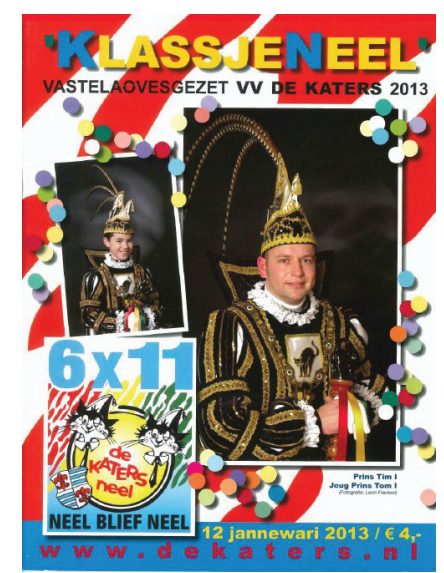

One last example stems from the carnival celebration of 2017. During the parade in Maasniel a group of people walked along under the slogan Neet in Neel gebaore, toch eine Kater gewaore (Not born in Neel, nevertheless became a Kater). Each individual of this group had a sign strapped around his or her neck that displayed in dialect where he or she was born: Zjwame (the former village of Swalmen near Roermond), Braobant (referring to Limburg's neighboring province of Noord-Brabant), Ruiver (Reuver, a village near Roermond), and Apeldoorn (a city in the Dutch province of Gelderland). In order to complement their performance, the group distributed and attached stickers along the route of the parade. These stickers resembled the Dutch stickers that people obtain from their municipality to stick to their mail box in case they do not want to receive unaddressed advertisements but only door-to-door papers (NEE-JA, NO YES) or in case they do not (NEE-NEE, NO-NO) want anything (see Figure 4.16).

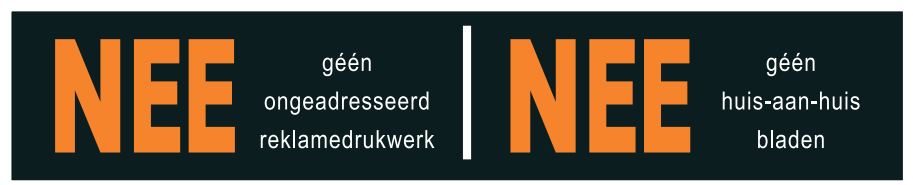

Figure 4.16: Examples of the NO-NO and NO-YES stickers that people can stick to their mailboxes to inform the mailman what advertisements

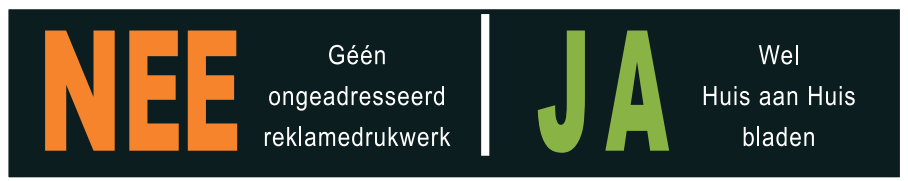
they would or would not like to receive (Image courtesy of Bas Methorst from Stichting MailDB)

Instead of the Dutch mailbox stickers, the stickers I found in Maasniel on road signs, poles, and lampposts stated in dialect (see Figure 4.17): "Ja: Neet in Neel gebaore, Neel: Toch eine Kater gewaore" (Yes: not born in Neel, Neel: nevertheless became a Kater). These stickers conveyed the fact that despite being born outside of Maasniel, a person could nonetheless become a Kater. The fact that these stickers were written in dialect would suggest that, in order to be considered in place as a Kater, one should at least understand dialect. 


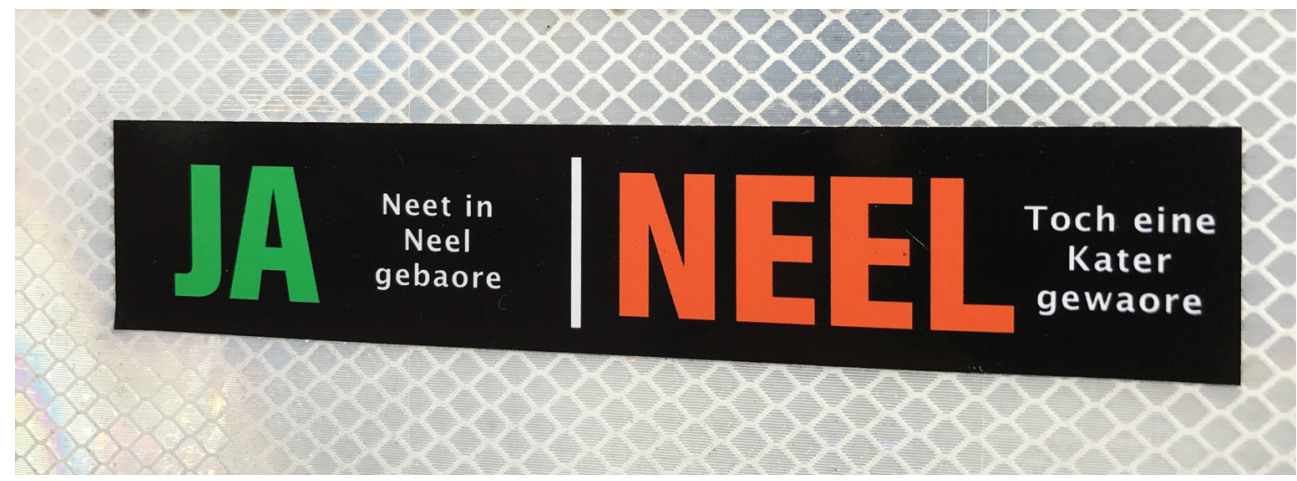

Figure 4.17: Photo of a sticker saying "Yes: not born in Neel, Neel: nevertheless became a Kater" attached to a road sign in Maasniel (taken by the author, April 8, 2017).

Within the spatial repertoires of De Katers, the display of written dialect thus seems to be firmly connected to the environment with which the association engages. For all instances of writing by De Katers carnival association within the borders of Maasniel, I argue that, through the exclusive use of dialect, the messages of the bulletin boards, the car and house decorations, the event billboard, the prince announcement gag, the magazine, and the stickers are also intended for a particular audience. As a result, these examples of spatial repertoires are concrete place-making practices that show what language practices are deemed to be in place and out of place (cf. Cresswell 1996). More important, these signs also seem to suggest what audience is included in the carnival celebration practices of De Katers carnival association and what audience is excluded from these practices, thus shaping the politics of (un)belonging (cf. Antonsich 2010; Christensen 2009; Savage et al. 2005; Yuval-Davis 2006, see Chapter 1).

\section{Conclusion}

This chapter aimed at addressing how people give meaning to the everyday places in which they live and how they shape understandings of locality, community, and region (cf. Gupta and Ferguson 1997) and ideas about what is considered appropriate (linguistic and cultural) behavior (cf. Cresswell 1996). In the first part of this chapter, I showed how people engage in various historical-territorial and material place-making practices to distinguish De Katers carnival association and to set Maasniel apart as a distinct place. I argued that the place-making practices employed produce, reproduce, negotiate, and challenge, in a Bakhtinian carnivalesque manner, different center-periphery dynamics (cf. Ang and Stratton 1996; Cornips and De Rooij 2018; Pietikäinen et al. 2016).

The research case on De Katers showed that carnival celebration practices in Limburg do not just reproduce a stereotypical and 'natural' connection between the province, carnival, and static ideas of 'Limburgerness' (cf. Thissen 2013), but that carnival celebration can be quite layered and complex in producing more local and smaller centerperiphery dynamics. The use of historical-territorial narratives by De Katers showed how salient oppositions within the nation-state seemed to recur within more local contexts (cf. Eckert 2011; Irvine and Gal 2000). Within the nation-state context, the opposition of 
Limburg vs. the rest of the Netherlands became meaningful after the negative integration (Knotter 2011) of Limburg into the Dutch nation-state. Within this local context of carnival celebration at De Katers, people identify, reproduce, challenge, and resist oppositions between Maasniel vs. Roermond historically based on Maasniel's negative integration within Roermond, between the old village center of Kern Maasnie/ vs. other Maasniel areas, and De Katers vs. other carnival associations.

Since the annexation of Maasniel by Roermond, dominant center-periphery relations have been constructed over time in which Roermond is the perceived center and Maasniel the perceived periphery. Through remembrance and reproduction of historicalterritorial narratives about the 'unjust' annexation of Maasniel by Roermond, the members of De Katers challenge, resist, and subvert this dominant power relation and centralize Maasniel at the expense of Roermond. In addition to the association's song, Neel blief Neel (Neel remains Neel), the tomcat statues, strategically placed at key locations in Maasniel, are perfect examples of how material objects can be used in place-making processes or myths (cf. Tuan 1991) to maintain the idea that Maasniel is a distinct place rather than acknowledge that Maasniel is an ordinary neighborhood of Roermond.

The power relations between the perceived center of Roermond and the perceived periphery of Maasniel seemed to recur on a more local level (cf. Eckert 2011; Irvine and Gal 2000): Kern Maasnie/ vs. other Maasniel areas. The pub tour through Maasniel and the distribution of De Katers magazine made it clear that De Katers distinguished between the old village of Maasniel (Kern Maasniel), which actively reproduces the Neel blief Neel ethos, while other areas within Maasniel were perceived as not being as faithful to this ethos.

De Katers also distinguished themselves from other carnival associations through other means, such as the prince's wearing 'decent' black lace-ups instead of leather boots. Obviously, center-periphery dynamics from one level influence dynamics on other levels. The Maasniel vs. Roermond power relationship was clearly employed in dealing with the D'n Uul (The Owls) carnival association from the city center of Roermond. In differentiating themselves from other carnival associations, De Katers reproduced the historical-territorial narratives about the 'unjust' annexation and used particular materials, such as the little owl next to the big tomcat.

Aside from these three constructed center-periphery dynamics, I have clarified how place-making practices produced distinctions and power relations within locations of De Katers events. The explicit use of many De Katers objects revealed the chairman's clear affiliation with a place (Maasniel) and a carnival association (De Katers), thereby exposing place-belongingness within a particular location (cf. Antonsich 2010). Moreover, I shed some light on the gendered place-making practices during carnival celebrations within the locations where De Katers held their events, which set aside places for women and places for men.

The second part of this chapter focused on linguistic place-making processes and the ways that linguistic forms were used in both interactions as well as on display during carnival celebration practices at De Katers. The public display of dialect writing shaped the spatial repertoire of carnival celebration in Maasniel. The exclusive use of dialect in display and actual language practices made it clear who and what behavior were perceived as being in and out of place and, thus, who was considered to belong or unbelong.

Through place-making practices, De Katers carnival association was able to set Maasniel apart from, first, the city of Roermond as a whole, second, from other areas of Maasniel and, finally, from other carnival associations. Subsequently, these place-making 
practices produced politics of (un)belonging about who and what behavior were perceived to be in and out of place. The next chapter will analyze a specific event of carnival celebration at De Katers carnival association to examine the role of linguistic forms in meaningmaking processes within a situated interaction and the construction of place and politics of (un)belonging. 


\section{Chapter 5}

\section{"And then we really switch to plat": Place-making and politics of (un)belonging through language choice in a carnival event at De} Katers

\section{Introduction $^{37}$}

This chapter analyzes a case of carnival celebration by De Katers carnival association in Maasniel, Limburg, the Netherlands, a village that was annexed as a neighborhood of the larger city of Roermond in 1959 (see Chapter 4). The carnival event under study here exemplifies that the taken-for-granted routine of using dialect in carnival celebration practices can be easily broken. During the event, the Dutch ritual of Sinterklaas, celebrated nationwide, was combined with the carnival celebration, resulting in a staged language choice between Dutch and dialect. I argue that this language choice was used by the actors on stage to engage in place-making processes and politics of (un)belonging. I will show that it is through place-making practices that attach meaning to the location of this particular carnival event that politics of (un)belonging are shaped, expressing who and what practices are perceived as belonging or in place while at the same time revealing who and what practices are deemed as unbelonging or out of place (cf. Christensen 2009; Cresswell 1996; Yuval-Davis 2006, see Chapter 1). I show that the actors of the event, by engaging in Bakhtinian carnivalesque practices, centralized the carnival celebration, dialect use, and Maasniel while peripheralizing the nationwide Sinterklaas celebration practices, the use of Dutch, and the city of Roermond. I argue that the eventual switch by Sinterklaas from Dutch to dialect and Monarch Eric's addressing Sinterklaas in dialect may be considered as a way to resist and subvert dominant center-periphery ideas.

During the announcement of the identity of the 2012-2013 season carnival prince, the nationwide celebration and ritual of Sinterklaas was combined with the local carnival celebration in Maasniel. This resulted in a staged encounter between two actors, De Katers' monarch (see Chapter 3) and the persona of Sinterklaas, and two language varieties, Dutch and dialect (see Chapter 1). The following quote of Monarch Eric reflects the central issues at stake in this chapter, namely the emergence of what the monarch called a 'language conflict' during the prince announcement event:

Eric: Ich dink det det auch was van: hei! Nederlands, dialek. Dao is van teveure helemaol neet, eh, neet euver naogedach of euver en auch neet euver gehad. En dan zuusse in ein keer van, eh, asse op de buhn sjteis van, hei, dao, eh, dao komme v'r in 'n conflik, of in een conflik, maarja, een taalconflik. Eh, van, geit hae [Sinterk-

\footnotetext{
${ }^{37}$ This chapter is almost entirely based on the paper "The politics of place-making and belonging through language choice within center-periphery dynamics in Limburg, the Netherlands," published in the volume "The Sociolinguistics of Place and Belonging: Perspectives from the Margins" (Cornips and De Rooij 2018). With special thanks to the editors, Leonie and Vincent, for including me in the edited volume and to Kees Vaes of John Benjamins Publishing Company for letting me use the chapter for this dissertation.
} 
laas] Nederlands kalle en ich dialek? Hè, want d'r waert van mich es vors verwach det ich 't waal in 't, eh, hè, in 't Neels doon.

I think it was also like: hey! Dutch, dialect. We did not, uh, not think about or talk about it at all in advance. And then you see all of a sudden, when you are standing on stage, hey, here, uh, we come into a conflict, or conflict, well, a language conflict. Uh, like, will he [Sinterklaas] talk Dutch and I dialect? Right, because I am expected, as monarch, that I do it, right, to do it in Neels [the perceived dialect of Maasniel].

(Interview with Monarch Eric, November 7, 2014)

The "language conflict" between what Monarch Eric called Dutch and dialect seems to have different meaning potentials due to enregisterment processes (cf. Agha 2007, 2008; Johnstone 2013), whereby dialect and Dutch are produced and perceived as different language varieties with their own characteristics and contexts of use. Monarch Eric's quote, "Will he [Sinterklaas] talk Dutch and I dialect?", reveals that Sinterklaas is apparently associated with the use of Dutch, while the monarch himself is expected to use dialect or Neels, the perceived dialect of Maasniel. The distinct registers under scrutiny here exist in other contexts as well, since they are part of larger, historical processes of enregisterment (cf. Agha 2007, 2008; Johnstone 2009, 2013) in Limburg through which Dutch and dialect have become associated with different social practices, places, personae, and rituals (cf. Cornips et al. 2016). In this chapter I argue that the language choice between Dutch and dialect must be understood against the background of dominantly held views of different center-periphery dynamics on the nation-state scale of the Netherlands and the regional and local scale of Limburg. These center-periphery dynamics are driven by the ideas that people in a particular place, region or country have about the dominant power relations of who is or is not in charge (cf. Giddens 1984; Hannerz 1989). The staged discussion on language choice and its outcome gained political significance that, in a carnivalesque manner, resisted and subverted dominant center-periphery dynamics.

This chapter is organized as follows. Section 5.1 introduces the celebration of Sinterklaas in the Netherlands and some of its specific rituals, such as the national welcoming event. I also describe how a sketch of a Sinterklaas television show tapped into dominantly perceived center-periphery dynamics between Limburg and the rest of the Netherlands. This is essential in understanding the prince announcement event at De Katers, which I also introduce in Section 5.1. Section 5.2 then starts by analyzing what was said during the prince announcement event. I then point out what ideological meaning is associated with the two language varieties, Dutch and dialect. Sections 5.3 and 5.4 analyze the produced place-making processes and politics of (un)belonging through language choice between Dutch or dialect and clarify how this relates to center-periphery dynamics between Limburg and 'Holland' on the one hand and Maasniel and Roermond on the other. The concluding section summarizes this chapter's main argument and offers some concluding remarks about Part I as a whole. 


\subsection{Sinterklaas and the carnival event at De Katers}

\section{The nationwide Sinterklaas celebration}

The nationwide Dutch celebration period known as 'Sinterklaas' revolves around the mythic character of Sint Nicolaas, also less formally known as Sinterklaas or, informally, Sint. The festive period commences with the arrival of Sinterklaas in the Netherlands from Spain in mid-November and ends on December 6 . Young children are told that Sinterklaas lives in Spain and travels by steamboat to the Netherlands to hand out gifts on his own birthday on December 5. The similarities between Sinterklaas and Christmas and Santa Claus are obvious, yet, instead of having elves as helpers, Sinterklaas is assisted by Zwarte Pieten (Black Petes), who carry gunny sacks with gifts and candy, which they deliver through chimneys. ${ }^{38}$ Two weeks before the celebration practices of Sinterklaas on December 5 , cities and villages organize local Sinterklaas arrivals in which Sinterklaas is welcomed from Spain to their sites by the respective mayors. These welcoming events mark the start of the Sinterklaas period as a whole, and this is also the period when public spaces are festooned with Sinterklaas decorations and shop owners start playing Sinterklaas songs in their stores. Sinterklaas as a national figure is associated with the use of Dutch (Cornips 2012; Helsloot 2012). Exceptions to this are 'dialect Sinterklazen' in Limburg (Schreuder 2007) and in Gelderland (De Gelderlander 2012) that are reported upon as something 'special' by journalists, strengthening the idea that Dutch alone is associated with the Sinterklaas celebration.

National television organizes and broadcasts the national arrival of Sinterklaas every year in a different city. It is only after this televised event that local Sinterklaas arrivals are organized (usually the day after). In 2012 the nationally broadcast arrival of Sinterklaas was held in Roermond. To support the promotion of the city on national television, the municipality of Roermond produced specially designed Sinterklaas flags and distributed them to inhabitants and entrepreneurs residing in the city center. These red flags depicted a yellow miter, the specific hat that Sinterklaas wears and that most people in the Netherlands recognize as such (see Figure 5.1). The accompanying letter to inhabitants and entrepreneurs invited them to put up the flags in order to make the streets appear festive for television shots.

Figure 5.1: Photo of the specially designed Sinterklaas flags distributed by the municipality of Roermond to inhabitants and entrepreneurs of the city center to put up on their houses during the 2012 parade celebrating Sinterklaas's national arrival in Roermond (taken by the author, November 15, 2012).

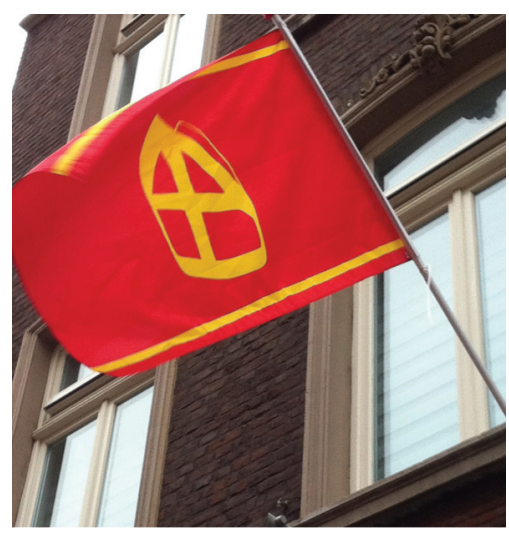

\footnotetext{
38 In recent decades, the Black Petes have become an increasing and recurrent topic of societal debate, due to accusations of racism (see Balkenhol 2015, contributions to Helder and Gravenberch 1998, and Helsloot 2012).
} 
Ever since 2001, the national arrival on television has been preceded by the children's daily soap Het Sinterklaasjournaal, also broadcast on national television. This 10-minute news bulletin reports daily on Sinterklaas's journey and preparations in the Netherlands, showing the highly mediatized national Sinterklaas celebration. In 2012, when the nationally broadcast arrival of Sinterklaas was held in Roermond, Het Sinterklaasjournaal shot a sketch in the city center of Roermond in which a reporter showed how Roermond was preparing for the arrival. ${ }^{39}$ A sketch was set up for the children that focused on a group of men who followed the reporter through the city center. Whenever something funny was said, the men yelled the carnival slogan, 'alaaf,' and, to trumpet accompaniment, performed the associated gesture, which involves placing the right hand by the left temple and making a diagonal upward motion three times (see Figure 5.2).

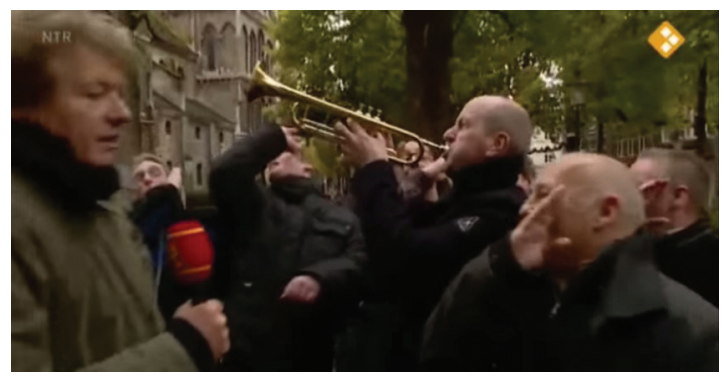

Figure 5.2: Screenshot of the Sinterklaasjournaal sketch where the men perform the carnival slogan, 'Alaaf,' to the reporter.

Many people in Limburg were furious about this nationally broadcast sketch, because Het Sinterklaasjournaal hired non-Limburgian actors who 'faked' a Limburgian accent while speaking Dutch, thereby stereotyping Limburgers as people who laugh at stupid jokes and yell 'alaaf' all the time, even in a Sinterklaas context. On the Facebook page of the L1 regional broadcasting company, the sketch was highly criticized: "Het klonk nergens naar, maar ach die 'Huil[I]anders' weten niet beter." ("It sounded totally off, but well, those 'Cry-landers' don't know any better.") The word huillander is an adaptation of the word 'Hollander,' which refers to people living outside of Limburg. The Dutch verb huil[en] (to cry) replaces 'Hol' to make fun of Hollanders. Another comment was: "Die stomme Hollanders moeten de Limburgers altijd op hun nummer zetten!" " Those stupid Hollanders always have to cut the Limburgers down to size!" $)^{40}$ These reactions show how Limburgers are irritated by the way Hollanders portray them. This in turn feeds into the dynamics of center and periphery in which "those inhabiting the (perceived) periphery feel marginalized economically, politically, culturally, and linguistically by the (perceived) center" (Wang et al. 2013: 14).

\footnotetext{
${ }^{39}$ See: https://www.youtube.com/watch?v=sMy_F_GGYL8.

${ }^{40}$ For more quotes, see the Facebook page of L1: http://www.facebook.com/L1 mburg. These quotes from Facebook were picked up by the national newspaper, De Volkskrant, see: http://www.volkskrant.nl/media/ boze-reacties-op-nep-limburgs-accent-in-sinterklaasjournaal a3347940/\#.UKS7W5I5Szk.facebook.
} 
The discussion on social media about Het Sinterklaasjournaal offers insights into the social perspectives of the people in Limburg on the power relations that are salient to them: 'they' in 'Holland' and 'Randstad' (roughly the western part of the Netherlands and the perceived center of the country) always make fun of 'us' in Limburg, the perceived periphery (cf. Thissen and Cornips 2015). These power relations seem to be reflected in the status and hierarchy of language practices (cf. Giampapa 2004; Pietikäinen and KellyHolmes 2013; Wang et al. 2013): people living in the center perceive the variety of Dutch that is spoken in the Randstad as the standard dominant and neutral variety, whereas they regard dialect varieties as different, inferior, and good targets to poke fun at (Cornips in press; Smakman 2006; Van Bezooijen 1997, 2002). People's language practices may thus tap into commonly experienced center-periphery dynamics.

Due to the city's efforts and media attention, most people in and around Roermond knew about the nationally broadcast arrival of Sinterklaas in Roermond in 2012. Maasniel's or Neel's De Katers carnival association was no exception to this. Its members saw in the coincidence of the national arrival of Sinterklaas in Roermond and their own prince announcement event an opportunity to use particular Sinterklaas rituals during the prince announcement event, such as the Sinterklaas rituals of gift-giving and gift-unwrapping and the reading aloud of Sinterklaas poems.

\section{The preparations for the prince announcement event at De Katers}

Six days after the opening of carnival season on November 11, De Katers held its prince announcement event, on the same day as the national arrival of Sinterklaas in the city center of Roermond. This inspired De Katers to incorporate the Sinterklaas celebration into its prince announcement event:

Eric: Wie v'r aan 't kieke ware van op waat veur daag gaon v'r det doon, veel det geliek met de landelijke intoch van Sinterklaos hiej in, eh, Remunj, oppe Roerkade. Dus v'r höbbe, eigelik haaje v'r zoget van, nouja dan gaon v'r eigelik d'r veur zorge det Sinterklaos mit al die pekskes wat 'r bie zich haet det 'r auch dae prins van De Katers van Neel bie zich haet.

When we were looking on what day to do that, it coincided with the national arrival of Sinterklaas, here in, uh, Remunj [Roermond in dialect], on the Roerkade [quay of the river Roer]. So we had, actually, we thought, like, well, then we arrange it that Sinterklaas, with all those packages he brings along, that he also carries with him the prince of De Katers from Neel.

(Interview with Monarch Eric, November 7, 2014)

For the role of the local Sinterklaas, De Katers asked a former prince who often performed as Sinterklaas at different clubs. Two members of the council and De Katers' photographer were asked to dress up and perform as Zwarte Pieten. While the general outline and roles of the announcement act were planned, the actual dialogues on stage were not. In playing his role, Monarch Eric told me he did make some preparations to build up to a climax during the announcement, but that he had not wanted to script the interaction with Sinterklaas (Interview, November 7, 2014). In this, he was aware that the audience was mainly there to see the new prince and not Sinterklaas, so he knew 
that he could not talk forever, since that would bore the audience.

In the days leading up to the prince announcement, I regularly checked the forum on De Katers' website, where many discussions were taking place about the main question: who would be the new prince of De Katers? Someone using the nickname de nuuje (the new one) posted: "Just four days to go!" Others guessed and threw around names of possible candidates. I myself became curious about who would be the new prince.

\title{
The entrance of De Katers and Sinterklaas
}

Even though I did not know the carnival association and its members that well yet, since the season had started just a week earlier, I was rather excited when I entered De Katers' residence café, De Ster, on the evening of Saturday, November 17, 2012, to attend and observe the prince announcement event of De Katers:

\begin{abstract}
Although other visitors have to enter the hall of Kater-palace De Ster directly via the entrance behind the café, I am allowed to join the confined gathering in the café up front with the association's council of eleven, the members of the board, their wives, and the orchestra. I join some members of the council at the bar and ask one of them whether he has any idea who the new prince will be. He does not seem to be very excited, shrugs his shoulders, and carelessly takes a sip of his beer. Another member shares his hopes for the new prince: "Young men often go to the city center to drink a beer, while I do that here, in Maasniel. So I hope the next prince will be a bit more Kater-minded." It seems that in fact only members of De Katers prince selection committee know who the next prince will be. The crowd in the café starts to move. The orchestra and council are lining up, and I make sure that I do not end up in their parade to enter the hall in the back. "Well, if you know the song, then get in line," a member jokes while referring to the association's theme song, Neel blief Neel (Neel remains Neel). I gather it is best to draw the line in my participation here and quickly go ahead to the hall.
\end{abstract}

(Field notes, November 17, 2012)

In the hall (see Figure 4.7 in the previous chapter for a map), the audience was waiting for the arrival of De Katers carnival association and to witness the prince announcement. Most of the audience stood in groups near the bar while having a drink and chatting. Eventually, De Katers carnival association made its entrance into the hall and, to everyone's surprise, Sinterklaas arrived as well after the first part of the event (the interactions of Sinterklaas's entrance will be discussed in more detail in the extracts of the following sections):

Shrill trumpets announce the entrance of De Katers into the hall with the first tones of the Neel blief Neel song. The audience falls silent and people clap along. The orchestra enters first, followed by the council of eleven, the monarch, and the chairman. While the group scatters around the hall, Monarch Eric gets on stage and takes up his usual hosting responsibilities and welcomes the audience. All of this is done in dialect. After the de-crowning of last year's prince, members of the council carry 'Sinterklaas-presents' on stage, the largest one of which - present number eleven - stands in the middle. The monarch invites the audience to sing 
along to Dutch Sinterklaas songs played by the orchestra. A man dressed up like Sinterklaas enters the room from the back and is accompanied by three Zwarte Pieten, who throw around strooigoed - a candy mix of pepernoten (gingerbread cubes), schuimpjes (marshmallow-like candies), and wine gums. Children in the hall joyfully gather up the candy, while the adults do what they can to avoid being hit and cover their glasses to prevent candy from ruining their drinks. Sinterklaas takes a lot of time to shake hands with people standing in the audience, while the monarch comments on the arrival of Sinterklaas and stands next to the large pile of Sinterklaas presents (see Extract 1 below). When Sinterklaas eventually finishes walking through the crowd and reaches the stage, the monarch exclaims in Dutch, "Welcome Sinterklaas!" and they shake hands while Sinterklaas is still standing on the floor (see Extract 2 and 3). Sinterklaas climbs on stage, where he first gently sways to the orchestra's music before the monarch and he explicitly discuss whether they will proceed in Dutch or plat (see Extract 4). As Sinterklaas seats himself in a stately chair (see Figure 5.3), the monarch explains that Sinterklaas has learned the dialect of Maasniel through an integration course (see Extract 5 below).

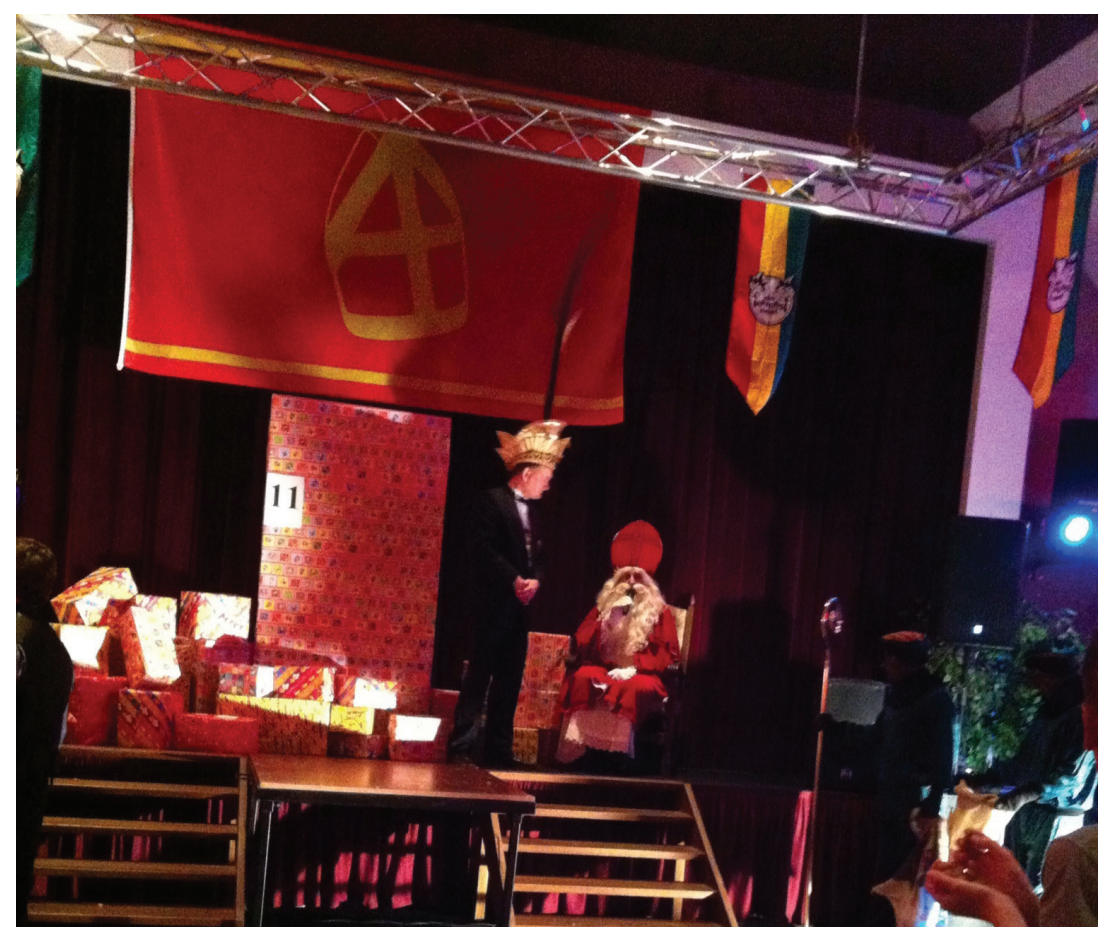

Figure 5.3: Photo of Monarch Eric (left figure), Sinterklaas (right figure), and the Sinterklaas presents on stage during the prince announcement event of De Katers (taken by the author, November 17, 2012). 
As soon as Sinterklaas had seated himself in his chair, the actual prince announcement started:

Sinterklaas assists the monarch in unwrapping the eleven presents that all contain an item and rhyming hints that refer to the identity of the new prince. The lower part of the large eleventh present is unwrapped and we, the audience, see a pair of legs in white tights wobbling nervously (see Figure 5.4).

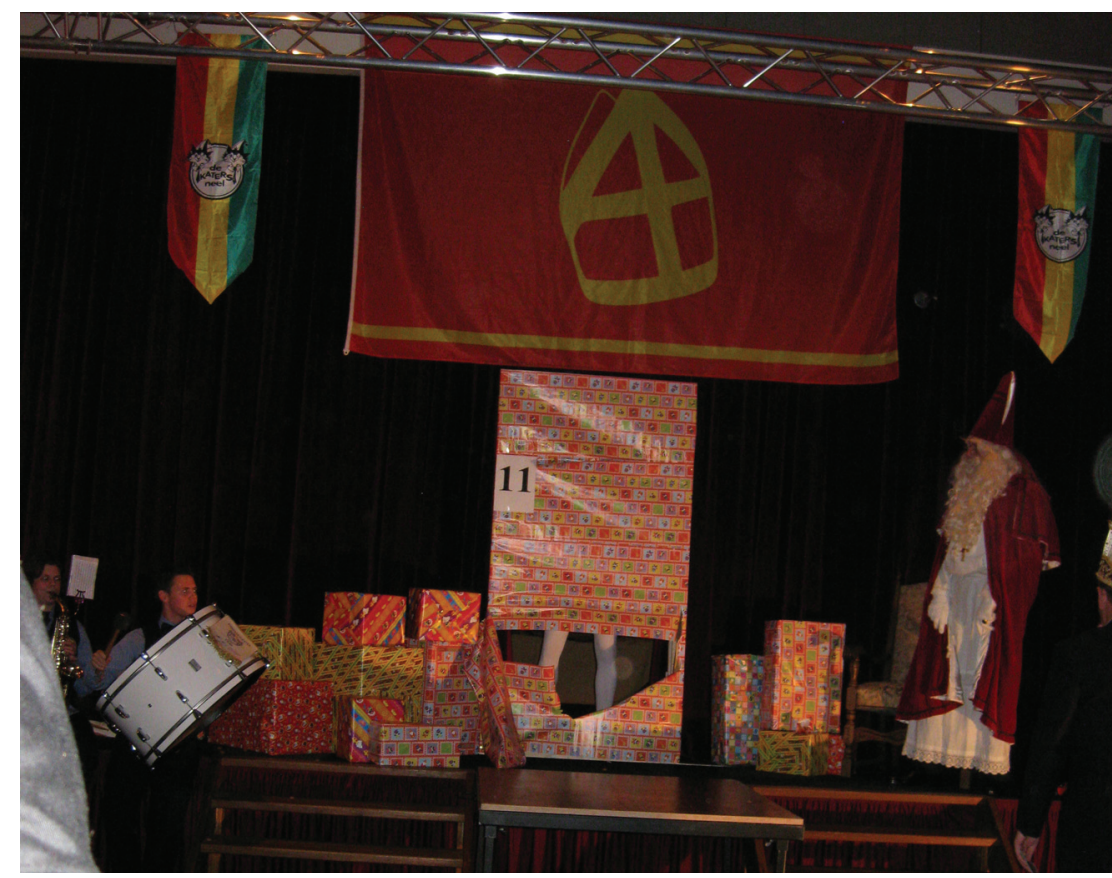

Figure 5.4: "A pair of white legs wobbling nervously," photo at the start of the revealing of the prince of De Katers carnival association (taken by the author, November 17, 2012).

People stopped talking, their attention completely riveted on the stage. The orchestra played rousing tunes to build up the tension while Monarch Eric, using a voice crescendoing in excitement, introduced this year's prince, a man by the name of Tim:

A man dressed up like a prince jumps out of the present. People around me cheer and clap loudly. Prince Tim starts dancing on the table in front of the stage. I see an overjoyed and proud man dancing in a beautifully decorated prince suit (see Figure 5.5). I am astonished: isn't that the man who sat at the bar less than two hours ago, sipped his beer, and carelessly shrugged his shoulders when I asked him who he thought would be the prince? Apparently Prince Tim is fit to play the role! (Field notes, November 17, 2012) 


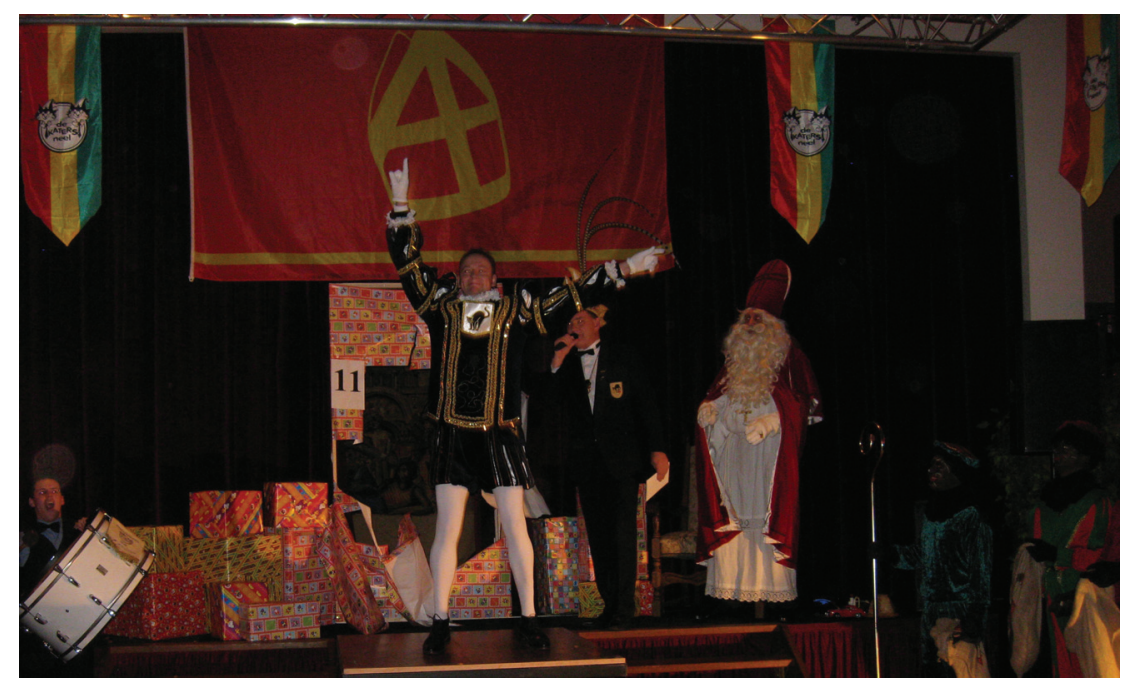

Figure 5.5: Photo of the revealing of Prince Tim I of De Katers carnival association (taken by the author, November 17, 2012).

\section{The dismissal of Sinterklaas by the monarch}

During the prince's dance on stage, Sinterklaas and the monarch were still standing on the stage behind the prince (see Figure 5.5). When the orchestra stopped playing, the monarch welcomed Tim and quickly thanked Sinterklaas and his Zwarte Pieten for their help. After the Sinterklaas-thematized announcement event, Sinterklaas and his helpers were hastily dismissed from stage, without even singing the traditional farewell song, Dag Sinterklaasje (Goodbye Sinterklaas-je ${ }_{\text {dim }}$ ). The prince's official inauguration demanded everyone's undivided attention.

The rituals of Sinterklaas celebration were thus used to thematize the prince announcement event at De Katers. However, as the vignette above described, the actual appearance of the new prince did not take place until the monarch and Sinterklaas had discussed the issue of language choice and which variety to use during the event. Carrying a voice recorder and taking photographs and videos with a digital camera enabled me to capture what the monarch and Sinterklaas said and did. The following five extracts reflect the interactions between the monarch and Sinterklaas. These extracts are numbered from 1 to 5 , but for purposes of analysis and clarity's sake, I will discuss them a-chronically.

\subsection{Language ideology in practice during the prince announcement}

Extract 1 below reflects the monarch's comments on Sinterklaas's entrance (the transcription conventions can be found at the beginning of this book before Chapter 1):

\section{Extract 1}

[Orchestra starts playing Sinterklaas song]

1 Monarch 'T is Sinterklaos (.) mit Zjwarte Piete! 
It is Sinterklaas (.) with the Black Petes!

2 Monarch Natuurlijk! (.) Die moge neet ontbraeke in dit sjpeel.

Of course! (.) They cannot be absent from this play.

3 Monarch Zjwarte Piete mit zjweigood!

Black Petes with strew candy!

4 Monarch Want det zjweigood xxx

Because that strew candy $x x x$

5 Monarch [tegen Zwarte Pieten] jongens kiek geer ein bietje oet?

[to Zwarte Pieten] guys, could you watch out?

In Extract 1, Monarch Eric used specific vocabulary, phonology, and a singsong intonation (cf. Hagen and Giesbers 1988), which were all recognizable as distinct from Dutch and stemming from dialect. First, the noun zjweigood in Line 3 and 4 was literally translated from the Dutch noun strooigoed. The verbs strooien (in Dutch) and zjweien (in dialect) both mean 'to throw around' or 'to strew,' while the Dutch noun goed - good in dialect - is a collective noun referring to a bunch of items or things. Instead of using the Dutch strooigoed, the monarch invented the dialect noun zjweigood on the spot, thereby safeguarding exclusive dialect use, since there is no established codified dialect equivalent of the Dutch strooigoed (Kats 1985: 285).

Second, the following subset of vowels and consonants were all clearly recognizable as dialect ${ }^{41}$ :

Line 1 Sinterklaos: [0:] instead of Dutch [a:]

Line 1 zjwarte (black): [3] instead of ' $z w$ ' in Dutch zwart

Line 1 mit (with): [l] instead of [ $\varepsilon$ ] in Dutch met

Line 2 sjpeel (play): [j] and [e:] instead of Dutch [sp] and [ع] respectively

Line 2 neet (not): [e:] instead of [i] in Dutch niet

Line 2 ontbreake (to lack): [ $\varepsilon$ :] instead of [e:] in Dutch ontbreken

Line 5 ein (a): [عi:] instead of [e:] in Dutch een

Line 5 kiek (to watch): [i:] instead of [عi] in Dutch kijk

Line 5 oet (out): [u:] instead of [œy] in Dutch uit

Finally, the monarch's use of dialect employed a characteristic singsong intonation in Lines 1 and 5 (see $\uparrow$ and $\downarrow$ ).

Extract 2 presents the interaction while the monarch of De Katers and Sinterklaas were shaking hands and Sinterklaas was still standing on the floor. When Sinterklaas made his way on stage, the monarch further commented on what was happening. This extract shows the monarch's switch from addressing the persona of Sinterklaas with Sinterklaas [a:] in Dutch in Line 1 to Sinterklaos [0:] in dialect in Line 2:

\footnotetext{
${ }^{41}$ I am indebted to Stefanie Ramachers, who corrected the phonetic notations of the vowels and consonants. I alone am responsible for any remaining errors.
} 


\section{Extract 2}

[Orchestra still plays Sinterklaas song]

1 Monarch Welkom, Sinterklaas!

[while shaking hands with Sinterklaas] Welcome, Sinterklaas!

[17 seconden pauze/17 seconds pause]

2 Monarch Sinterklaos!

Sinterklaos!

While Monarch Eric exclusively used dialect in Extract 1, he started Extract 2 in Dutch in Line 1, then switched to dialect in Line 2, thereby revealing what the monarch called "the language conflict." In Line 1, the monarch addressed Sinterklaas directly, while shaking his hand and greeting the person of Sinterklaas in Dutch. The monarch then switched, after an extraordinarily long pause of 17 seconds, to dialectal Sinterklaos in Line 2, while addressing the audience that expected him to talk dialect or Neels on stage, as the monarch elucidated earlier in the interview excerpt. The use of Dutch in Line 1, Extract 2 broke the routine of the otherwise structured carnival event, where dialect was usually used without a moment's hesitation. The monarch's 17-second pause in Extract 2 suggested his realization that he had spoken Dutch at a carnival event as well as his discomfort at speaking dialect in the presence of Sinterklaas.

It is through this alternation between Dutch (Sinterklaas) and dialect (Sinterklaos), that the enregisterment of both language varieties becomes clear: the nationwide celebration of Sinterklaas is associated with Dutch, as the special report on appearances of a 'dialect-Sinterklaas' highlighted earlier, while the local celebration of carnival is associated with dialect (see Chapter 4). However, Extract 2 shows that the monarch broke with these enregistered language routines: he spoke Dutch during a carnival event when welcoming Sinterklaas.

This break with the language routine of carnival practices should be understood against the background of power asymmetries between the center of 'Holland' and the periphery of Limburg, as they are experienced in the social reality of everyday life in Limburg (witness the sketch from Het Sinterklaasjournaal and its reactions in Section 5.1). These power asymmetries explain why Monarch Eric could not continue on stage without first discussing the language situation, since continuing to speak Dutch during the event would reproduce the dominant power relations of 'Holland' as the center and Limburg as the periphery while engaging in local carnival practices. Consequently, the monarch's switch between Sinterklaas and Sinterklaos in Extract 2 exemplifies what Johnstone (2009: 162-163) has called third order indexicality: the language varieties of Dutch and dialect become available to produce localness and local pride and identity at this stage of the prince announcement event, as I will show next.

\subsection{Place-making processes and politics of (un)belonging through language choice}

The language discussion

In examining normative and ideological structures of places, Cresswell (1996: 9-10) recognizes temporal and more permanent transgressions as vital moments that lay bare 
accepted and unwritten rules of how things are done in particular places. From this angle, I consider the entrance of Sinterklaas, associated with the use of Dutch, as a moment of transgression within the place of De Katers carnival association that held a mirror to the association's otherwise structured carnival event where dialect use was taken for granted. The entrance of Sinterklaas broke the register-routine, through which the correlation between place (residence café De Ster) and appropriate linguistic behavior (the use of dialect) became recognizable. As a result, Sinterklaas was construed as being 'the other,' who was different, because the monarch said Sinterklaas instead of Sinterklaos to him, as Extract 2 exemplified.

When Sinterklaas finally got up on stage, Monarch Eric made a gag about how he and Sinterklaas had planned this event on the telephone, thereby spotlighting the linguistic encounter between the Dutch practices of Sinterklaas and the dialect practices of the carnival event at hand. In Extract 4 below, the monarch recounted in dialect how he and Sinterklaas had had a discussion on the phone (Lines 1 through 3) about which language variety to use (Lines 4 through 6), how they resolved it by agreeing on the use of plat (Line 8 and 9), and how they actually switched to dialect (Lines 10 through 12):

\section{Extract 4}

[Audience is loud]

1 Monarch Goojemiddig, Sinterklaos. (.)

Good afternoon, Sinterklaos. (.)

2 Monarch Ich hooj Sinterklaos vanmiddag nog aan de tillefoon, This afternoon I spoke to Sinterklaas on the phone,

3 Monarch direk nao ziene intoch, in de sjtad (.) immediately after his arrival, in the city center (.)

4 Monarch En toen heb ich mit 'm euverlag, And then I discussed with him,

5 Monarch Ich zik, Sinterklaos, doon v'r det in 't Nederlands I say, Sinterklaos, are we going to do that in Dutch

6 Monarch of doon v'r det in 't plat? or do we do it in plat?

7 Monarch Nou, zaet 'r (.) nou zik 't zelf maar, Well, he said (.) well say it yourself,

8 Sinterklaas Nou (.) we gaan over naar het plat. Well (.) we're switching to plat.

9 Monarch We gaan over naar het plat. We're switching to plat.

10 Monarch Nou dat is goed, Sint Nicolaas, dan zou ik zeggen, neem Well that is good, Sint Nicolaas, then I would say, take a

11 Monarch plaats in (.) uw eigen stoel, seat (.) in your own chair,

[Sinterklaas walks to the chair and takes a seat]

12 Monarch en dan gaon v'r ech euver in 't plat. and then we'll really switch to plat.

While at first speaking dialect to Sinterklaas in Line 1, the monarch realized he needed to explain the "language conflict." Apparently, he could not continue the prince 
announcement event without first problematizing and then finding a solution to the conflict. In Cresswell's words (1996: 18-19), the monarch had to react to the transgression represented by Sinterklaas.

Therefore, the monarch acted as if he and Sinterklaas had had a telephone conversation that afternoon to resolve the conflict (Line 2). By doing so, the linguistic differences between the monarch and Sinterklaas were highlighted and exaggerated in order to sharpen the distance (Johnstone 2013) between Dutch and dialect. Although the monarch and Sinterklaas could have understood each other perfectly well, since both speak Dutch and dialect in real life, the encounter with the otherness of Sinterklaas, who is associated with the use of Dutch, had to be made explicit by discussing the language situation. By explicitly associating Sinterklaas with Dutch, the distance was sharpened between the monarch and De Katers carnival association on the one hand and Sinterklaas on the other hand. To that end, the monarch asked Sinterklaas to choose between Dutch or plat (dialect) in Lines 5 and 6 . The explicit meta-linguistic discussion in Lines 5 and 6 shows the influence of enregistering processes and third order indexical meaning production on people's interactions (cf. Agha 2007, 2008; Johnstone 2009), since it emphasizes how Dutch and dialect in this context are contrasted, due to the association of Dutch with the nationwide celebration of Sinterklaas and dialect with the local and regional celebration of carnival.

After having asked whether they should continue in Dutch or plat (Line 6), the monarch invited Sinterklaas, already in dialect, to share the outcome of their alleged telephone conversation (Line 2). Sinterklaas announced the decision that they would switch to plat (Line 8). However, before the monarch and Sinterklaas actually did so, they both still used Dutch in Lines 7 and 8. The actual switch to dialect (in Line 12 of Extract 4) required a run-up (Lines 8 through 11) to prove that Dutch was certainly not the appropriate register to use for this carnival event. Below, I argue that in doing so the monarch and Sinterklaas centralized the use of dialect while peripheralizing the use of Dutch.

\section{Centralizing dialect, peripheralizing Dutch}

The language discussion clearly exemplifies how transgressions and the reactions to them reveal the values that are considered correct and appropriate in a particular place (cf. Cresswell 1996): dialect use is apparently deemed appropriate within the place and context of De Katers carnival association's event. A Dutch-speaking Sinterklaas would be too much of a deviation within this carnival event, especially taking into account the perceived asymmetrical power relations between Limburg and 'Holland' - illustrated by the discussions about the sketch of Het Sinterklaasjournaal. Something thus needed to be done in order to restore the broken register-routine and to incorporate Sinterklaas's 'otherness' into the event. Subsequently, this would prevent reproducing Dutch and 'Holland' as the center and dialect and Limburg as the periphery at the local level. To do this, the monarch and Sinterklaas used particular linguistic and stylistic forms in place-making practices that transform space into 'lived' and socially produced places by attaching linguistic and socio-cultural meaning to the involved location (cf. Cresswell 2009; Modan 2008; Pred 1985). The monarch's use of his invented word, zjweigood (Extract 1), was a place-making strategy through the use of 'pure' dialect.

The language discussion in Extract 4 shows that dialect practices were attached to the place where De Katers held its events, namely in De Katers' residence café, De Ster, in Maasniel. Paradoxically, to prove the inappropriateness of Dutch, the register-routine of 
carnival (cf. Agha 2008) was challenged and temporarily broken by the switch to Dutch when welcoming Sinterklaas and holding a metalinguistic discussion. For the sake of convenience, I repeat Lines 7 and 8 (Extract 4) below:

\section{Extract 4}

7 Monarch Nou, zaet 'r (.) nou zik 't zelf maar, Well, he said (.) well say it yourself,

8 Sinterklaas Nou (.) we gaan over naar het plat.

\{[posh Dutch accent] Well (.) we're switching to plat. [/posh Dutch accent]\}

The utterance of Sinterklaas in Line 8 in Dutch was produced in an exaggerated manner: every word was very carefully articulated, and Sinterklaas used a stylized accent that could be interpreted as deftig or 'posh.' Dutch people typically refer to this way of speaking as 'talking with a hot potato in one's mouth' or 'talking like the Queen,' referring to the affected and posh manner of speaking of the former Queen of the Netherlands. The fact that plat was uttered in a posh accent is very important, since this seems to grant third indexical order meaning (cf. Agha 2007, 2008; Eckert 2008; Johnstone 2009) to the Dutch register as being associated with locations and people outside Limburg ('Holland' and especially the Randstad area) who are, among other things, perceived by Limburgers as rude, stingy, and arrogant (Mathijsen 2011: 20). Obviously, these third order indexical meanings differ by person and context. Yet in this particular context, I believe it is exactly this third order indexicality of Dutch that was invoked by Sinterklaas's posh pronunciation through which the use of Dutch became inappropriate during the prince announcement event. Even though Sinterklaas was already perceived as 'the other,' he himself was actively co-constructing this otherness by speaking Dutch in a posh accent and referring to himself using the majestic plural or royal 'we' form in Line 8, Extract 4.

After the monarch's stylization of "we gaan over naar het plat" ("we're switching to plat") in posh Dutch in Line 9 (repeated below), he nonetheless continued speaking Dutch. The monarch pronounced the utterances in Dutch in Line 10 and 11 at a much slower pace ([dc]) compared with the dialect utterances that followed ([ac]).

\section{Extract 4}

9 Monarch We gaan over naar het plat. \{[posh Dutch accent] We're switching to plat. [/posh Dutch accent]\}

10 Monarch $\{[d c]$ Nou dat is goed, Sint Nicolaas, dan zou ik zeggen, $\{[d c]$ Well that is good, Sint Nicolaas, then I would say,

11 Monarch neem plaats in (.) uw eigen stoel, \} take a seat (.) in your own chair,

[Sinterklaas walks to chair and takes a seat]

12 Monarch $\{[a c]$ en dan gaon v'r ech euver in 't plat.\}

$\{[a c] a n d$ then we'll really switch to plat.\}

The slower pace suggested an enacted discomfort of Monarch Eric at speaking Dutch on stage, while at the same time emphasizing that a Dutch-speaking Sinterklaas was considered as unbelonging in this place due to the posh pronunciation of Dutch as well as the use of the very formal and old-fashioned term Sint Nicolaas (Line 10). This seemed to reinforce the out of placeness of using Dutch at a carnival event. In Line 11, the 
monarch invited Sinterklaas, in Dutch, to sit down in his own chair by using the second possessive polite pronoun uw (your) to refer to the chair, thereby reinforcing the posh status of Sinterklaas.

From that moment on, the monarch and Sinterklaas continued talking in dialect, as shown in Line 12, where the monarch switched back to dialect. In that line, the monarch stressed ech (really) to mark that, in his opinion, they had been talking Dutch too long in this context, albeit in a posh, fake, and affected manner. In contrast with Dutch, dialect was thus reproduced as the appropriate register associated with Limburg and, among other things, carnival celebration (cf. Knotter 2009; Mathijsen 2011). In that sense, dialect use linked up to feelings of 'Limburgerness' that usually render familiarity, intimacy, and cultural and linguistic similarity to its users (cf. Thissen 2013). This also held true for the prince announcement event, where the monarch's resumption of a normal pace of speaking dialect in tandem with Sinterklaas's taking a seat and his use of dialect combined to create an intimate and familiar setting.

Furthermore, by using the label 'plat,' the monarch further construed dialect as the preferred way of speaking in this specific context. Earlier, in Chapter 4 (Section 4.2), De Katers saxophonist Wim indicated that "you just have to speak plat" in comparison with Hollands (Hollandic), thereby implying the closeness and familiarity that dialect offers when a group can "just" speak it together. I argue that the eventual switch from Dutch to dialect or plat clarified the social meanings with which Dutch and dialect were associated: within this carnival context in Limburg, the use of posh Dutch by Sinterklaas, the monarch's slower and imitated posh way of talking, addressing Sinterklaas as Sint Nicolaas, and using the second possessive polite pronoun uw (your) by the monarch represented perceived Hollandic arrogance, affectation, and distance, whereas the use of dialect indexed feelings of comfort, closeness, and familiarity within Limburg. Due to the third order indexical links (cf. Johnstone 2009) between Sinterklaas and Dutch, the monarch perceived Sinterklaas as the embodiment of the center of 'Holland,' while dialect was associated with the ritual of carnival and the periphery of Limburg.

The decision by the monarch and Sinterklaas to use dialect should thus be regarded as a way to avoid incorporating aspects associated with the center of 'Holland' within a carnival event associated with the periphery and the use of dialect. In essence, dialect 'pushed Dutch aside.' In other words, the use of dialect was centralized while Dutch was peripheralized. In doing so, the monarch and Sinterklaas related in a carnivalesque manner (cf. Bakhtin 1984) to center-periphery dynamics by resisting and subverting dominant hierarchies and power relations. In addition, through language choice and the decision to use dialect, the event also centralized the ritual of carnival celebration by peripheralizing and localizing the persona of Sinterklaas, so that Sinterklaas was no longer associated with the center of 'Holland.'

In sum, this event and the contrast between the language practices of Sinterklaas and the monarch offer insight into the ideas about who and what behavior belong or are in place within a particular context and who and what behavior unbelong or are out of place (cf. Antonsich 2010; Christensen 2009; Cresswell 1996; Yuval-Davis 2006). In the context of the prince announcement at De Katers, Sinterklaas and Dutch, posh Dutch and slowly spoken Dutch were produced as unbelonging or being out of place due to their association with the center of the Netherlands, whereas carnival, the monarch and dialect use were produced as belonging or being in place due to their association with Limburg, the periphery of the Netherlands. 
During the prince announcement event, expected roles and patterns of behavior were reversed and subverted: a carnival monarch spoke Dutch very briefly and Sinterklaas talked dialect. Yet these Bakhtinian subversions, which suspend hierarchies between people and allow for unconventional modes and 'carnivalesque mésalliances' (Bakhtin: 1984: 122123), were not only visible in place-making processes and politics of (un)belonging through the choice of dialect; carnival celebration was also centralized through the subordination of the figure of Sinterklaas and Sinterklaas rituals to carnival celebration practices.

The role and behavior of Sinterklaas during the prince announcement at De Katers also reversed and subverted typical conventions for Sinterklaas rituals and behavior in the Netherlands. The vignette in Section 5.2 described how Sinterklaas danced along to the orchestra's music on stage. Usually, Sinterklaas is a formal man who speaks in a posh manner and behaves accordingly: he waves to children and shakes hands but does not dance or sing along with Sinterklaas songs. Since it is his birthday, he usually just listens to the audience that sings to him, without participating in singing, and he asks his Zwarte Pieten to hand out candy and gifts.

Furthermore, the Sinterklaas rituals of gift-giving and gift-unwrapping were used by De Katers carnival association to thematize its carnival event. As a result, Sinterklaas as a figure was subordinated to the carnival celebration by assisting in a carnival ritual without being in the spotlight - as would be usual during Sinterklaas celebration events - and unpacking the eleven presents himself instead of handing them out to children. During the event, Monarch Eric explicitly commented on the reversed situation in which Sinterklaas was now expected to unwrap presents himself instead of handing them out: "Ja,'t is ein bietje de omgedreide wereld. Normaal brengt geer [second person polite form] de kadootjes aan miense" ("Yes, it's the world turned upside down a little bit. Normally, you [second person honorific form] bring the presents to people.") The use of the second person polite form geer in the enregistered dialect of Roermond (Kats 1985: 297), which translates in English as the second person honorific form of 'you,' emphasized once more that Sinterklaas is generally regarded as a formal and posh figure, though this particular Sinterklaas at De Katers' prince announcement event did not behave accordingly.

Finally, when the new prince emerged from the eleventh present and was about to be officially inaugurated, Sinterklaas and the Zwarte Pieten disappeared unobtrusively, without saying goodbye or the audience's singing the traditional farewell song, Dag Sinterklaasje (Goodbye Sinterklaasje ${ }_{\text {dim. }}$ ). The eventual switch to dialect by Sinterklaas helped to subordinate and localize the ritual and persona of Sinterklaas, associated with the center of 'Holland,' to the ritual of carnival, associated with the periphery in Limburg at the nation-state scale. Yet the data show even more complex place-making processes that relate to more local dynamics of center and periphery, namely between Maasniel and Roermond.

\title{
5.4 Local place-making processes and politics of (un)belonging
}

\author{
Neel blief Neel!: Centralizing Maasniel, peripheralizing Roermond
}

Center-periphery power dynamics may recur on or fractalize all the way down to other societal levels, depending on time, space, and context (Eckert 2011; Gal and Irvine 1995). 
Besides the distinction of De Katers' practices within Holland-Limburg dynamics, the entrance of Sinterklaas also offered opportunities to strengthen the distinctiveness of De Katers within the local configurations of center and periphery, namely the power relations between the city of Roermond and the former village of Maasniel.

Until 1959 Maasniel (Neel) was an independent municipality, after which it was 'unjustly annexed' - as members of De Katers argued - by the city of Roermond. The independent village identity of Maasniel is still remembered today by De Katers carnival association through its association song, Neel blief Neel, and the statues of tomcats within Maasniel (see Chapter 4). During the prince announcement, the monarch reproduced the tense relations between Maasniel and Roermond by referring to Neel many times and using particular phrasings and anecdotes to emphasize De Katers' belonging to Maasniel. Extracts 3 and 5 below show how language practices relate to place-making processes and politics of (un)belonging within center-periphery dynamics, since Monarch Eric explicitly marked off Maasniel as a distinct place in comparison with Roermond.

In Extract 3, directly following Extract 2, the monarch exclaimed that it was quite special that Sinterklaas was already in "our own Neel," right after arriving in the city center of Roermond (Line 1 and 2). He thereby implied that Sinterklaas did not bother to stay too long in the city center of Roermond, preferring instead to come right away to Maasniel upon arrival. Moreover, he pointed out that De Katers carnival association had the same flags as the city center of Roermond (Line 3 and 4). With this, he referred to the flags (see Figure 5.1) that had been specially designed for the national welcoming of Sinterklaas in Roermond and distributed to the inhabitants of the city center.

\section{Extract 3}

1 Monarch Direk nao de intoch, geweun in os eige Neel!

Right after the arrival, just in our own Neel!

2 Monarch Wo kriegse 't vaerdig?

Where else do you achieve this?

3 Monarch En natuurlijk höbbe veer (.) de originele vlagge zo-as dae in

And of course we have (.) the original flags as they had in

4 Monarch de sjtad honge (.) die höbbe $\uparrow$ veer ouch!

the city center (.) $\uparrow$ we also have them!

[Orchestra starts playing two other Sinterklaas songs]

Monarch Eric's emphasis on possessing the original Sinterklaas flags challenged the hierarchy of both places in a Bakhtinian carnivalesque manner by placing Maasniel on the same level as Roermond: De Katers had acquired something that was especially designed for the city center. It seems as if the monarch tried to convince everyone that Roermond was not so special, because Maasniel also had these flags, thereby resisting commonly felt center-periphery dynamics and subverting and undermining the dominantly held view on power relations.

After the decision that Sinterklaas would also switch to dialect, the monarch clarified Sinterklaas's ability to speak dialect in Extract 5 (which directly follows Extract 4):

\section{Extract 5}

1 Monarch Want hae haet 'ne inburgeringscursus (.) gevolg in Sjpanje, Because he had taken an integration course in Spain, 

2 Monarch in de tied det ' $r$ (.) ja neet in Nederlandj is.
in the time that he (.) yes that he was not in the Netherlands.
3 Monarch Dan haet ' $r$ tied zat.
Then he has plenty of time.
4 Monarch Dus hae haet zich eigelik verdiep (.) in 't Neels (.)
So he had deepened himself (.) in Neels (.)
5 Monarch en in 't (.) Neelse dialek.
and in the (.) Neels dialect.

The monarch 'revealed' that Sinterklaas had taken an integration course through which he had acquired "Neels." In this, a national societal measure like the integration course, designed for immigrants, refugees and people with temporary residence permits, was applied to the local level of Maasniel. "Neels" and "Neels dialect" (Lines 4 and 5) can be seen as ideological labels that were used by the monarch, first of all, to highlight that 'Neels' was something one had to learn through a special course in order to become a proper member of Maasniel. It may be surprising that the dialect of Maasniel would even be labeled as such, since inhabitants of Maasniel have difficulties pointing out the linguistic differences between what is spoken in Maasniel and Roermond. De Katers member Frank referred to only two words that are different in his perspective: in Roermond people would say veur ('before,' 'for' or 'in front') and versiere ('to decorate') while in Maasniel people would say veer and versere (Interview with Frank, January 2, 2014).

During the theater night of De Katers in January 2013, there was a sketch that was quite similar to the prince announcement event. In the sketch, someone performed the role of then Queen of the Netherlands, Beatrix, who had just announced her abdication as queen. While the queen entered the hall, someone on stage sang the Dutch national anthem, during which the audience had to rise and some members of De Katers waved Dutch flags. Once the queen got on stage, she announced that she did not want to miss out on De Katers' anniversary season and that she wanted to congratulate its members in person during her last reigning year. She initially started her speech in Dutch, after which she made an explicit reference to the use of dialect. Similar to the Sinterklaas sketch during the prince announcement, De Katers had asked the queen to attend dialect training at dialect organization Veldeke so that she could give her speech in dialect. After this, the queen switched to dialect (Field notes of Bonte Aovend/Theater night, January 19, 2013).

Where the queen sketch did not distinguish between local dialects from Roermond or Maasniel, during the Sinterklaas sketch, the monarch tried to guard the boundaries of the locality of Maasniel by using the labels "Neels" and "Neels dialect" despite the minor differences between the dialects of Maasniel and Roermond. He thereby sharpened and enlarged the distance (cf. Johnstone 2013) between the dialect and the localities of Roermond and Maasniel during the prince announcement event. Tuan (1991) argues that speech can direct attention, organize insignificant entities into significant composite wholes, and, in so doing, make things visible, viable, and real (ibid: 685). Tuan specifically underlines the impact of naming in place-making processes: naming renders an object visible and imparts a certain character to things (ibid: 688). In line with Tuan (1991), I regard the label, "Neels dialect," as a place-making strategy. The label not only exposed perceived local power relations, it also transformed a specific space into a meaningful place and centralized Maasniel and its dialect and peripheralized Roermond. As a result, Maasniel was made into a separate place with its own dialect standing apart from other places - Roer- 
mond above all - instead of merely being its periphery; thus, in a carnivalesque manner, resisting and subverting dominant center-periphery dynamics through linguistic place-making processes and politics of (un)belonging.

\section{Conclusion}

By demonstrating the sensitivities of a seemingly simple language choice during a carnival event in the former village of Maasniel in the Dutch province of Limburg, this chapter showed how language practices may shape place-making processes and politics of (un) belonging, and vice versa, within the dominantly perceived center-periphery dynamics between Limburg and 'Holland' and Maasniel and Roermond, thereby revealing who is perceived as in and out of place. During De Katers carnival association's prince announcement, the rituals of the local carnival and nationwide Sinterklaas celebrations were combined. Though everyone expected the monarch to use dialect during the carnival event, the host of the event, Monarch Eric of De Katers, used Dutch to address Sinterklaas. The mere fact that the event could not proceed without resolving this language choice on stage revealed that there was meta-linguistic awareness of what would be considered appropriate linguistic behavior within this event in this place. The two rituals were associated with two different language varieties: Sinterklaas celebration practices were linked to Dutch and carnival celebration practices to dialect. However, despite the ideological presumption that carnival is linked to dialect and Sinterklaas to Dutch, Dutch was used at first in the carnival event, and only later did Sinterklaas eventually switch to dialect. This switch to dialect was only possible after the monarch and Sinterklaas engaged in specific linguistic strategies to agree on dialect as being the appropriate language variety for the event, leaving Dutch as the odd one out. These strategies included the 17-second-long pause during which the monarch became aware of the language choice, several meta-linguistic comments that contrasted Dutch and dialect, the posh accent and slower pace in Dutch that underlined the artificiality of Dutch in carnival celebration, and the invention and use of zjweigood to secure 'pure' dialect use. Consequently, they decided that dialect would 'push aside' the inappropriate variety of Dutch during this local event.

Similar to the irritation elicited by the sketch of Het Sinterklaasjournaal about 'Hollanders' who stereotype Limburgers (see Section 5.1), the language choice between Dutch and dialect at De Katers carnival association served as an example of Limburg inhabitants' awareness of their peripheral position within the nation-state when they encounter Dutch language practices that they associate with the center of 'Holland.' The decision to use dialect was therefore not neutral and was related to dominant center-periphery dynamics in two ways.

First, within this carnival event held in the perceived periphery of Limburg, dialect was the best option in order to avoid incorporating Dutch, usually associated with the perceived center of 'Holland.' Through the choice of dialect, the monarch and Sinterklaas engaged in place-making practices and politics of (un)belonging that negotiated dialect and the carnival celebration as being in place, while a Dutch-speaking Sinterklaas was held to be out of place. Hence, dominant power relations between Limburg and 'Holland' were not only resisted but also subverted in a Bakhtinian carnivalesque manner. Part of this subversion was the peripheralization of the Sinterklaas celebration as a whole by incorporating it into and subordinating it to the carnival celebration, thereby turning Sinterklaas rituals 
upside down in a carnivalesque way and localizing the celebratory tradition of Sinterklaas as a whole.

Second, yet equally important, De Katers' monarch also engaged in more local place-making processes and politics of (un)belonging that resisted and subverted the processes of centralization and peripheralization, thereby centralizing the otherwise perceived periphery of Maasniel and peripheralizing the otherwise perceived center of Roermond. The 'otherness' of Sinterklaas and the resulting language discussion were thus used to play with and subvert, in a carnivalesque manner, dominant power relations to produce De Katers' event as an event set in Limburg, not 'Holland,' and in Maasniel, not Roermond, where dialect and the carnival celebration belong or are in place, while a Dutch-speaking Sinterklaas unbelongs or is out of place.

Part I provided insights into the ways that people give meaning to places in their carnival celebration practices within the context of Limburg. Contrary to common ideas about peripheral areas in general (De Lima 2012) that present Limburg as a homogeneous and harmonious area in the periphery of the Netherlands, where people share a clear-cut regional identity, talk dialect, and celebrate carnival, this research into the case of De Katers shows us that actual language and cultural practices found within the province are much more dynamic than these stereotypes would suggest. By focusing on De Katers carnival association, I have shown how members of this association engaged in place-making practices that produced Maasniel as a distinct place within the city of Roermond. Moreover, I have analyzed a particular case of carnival celebration to exemplify how place-making processes were put into practice during an event, thus shaping politics of belonging and unbelonging. Despite the ideological belief that carnival practices are inextricably connected to dialect use, I have shown that other linguistic forms can in fact be used, depending on the communicative goals and the place in which people use these forms. This strengthens the claim that there is a discrepancy between what people say and believe they do and what they actually say and do (Labov 1966) within situated interactions (cf. Gumperz 1997). The situated interaction between De Katers' monarch and Sinterklaas particularly exemplifies that perceived peripheral areas are actually far more pragmatic and dynamic in terms of 'multilingual' practices than is generally assumed (Kelly-Holmes and Pietikäinen 2015).

Moreover, I have shown that people in Limburg produce many recurrent centerperiphery dynamics through place-making practices that show who and what behavior are perceived as in place or belonging and out of place or unbelonging within specific places. The nationally dominant power relations between 'Holland' (center) and Limburg (periphery) are thus reproduced on more regional and local scales, resulting in recurrent and smaller center-periphery dynamics, demonstrating that constellations of centers and peripheries are continuously changing, disappearing, and reappearing through people's practices (Harrison 2015).

The focus on two men and their everyday chitchat on the Roermond city center's Munsterplein plaza in Part II of this dissertation will serve to support further the premise that there is a difference between reported behavior and actual behavior and will clearly show that the use of dialect of Limburg is not limited to just people who are born in the province. Moreover, Part II will provide insight into more individual processes of place-making and questions about what it means for a person to feel both in as well as out of place in Limburg and Roermond. 


\section{Part II}

The everyday chitchatting practices of two men on Roermond city center's Munsterplein plaza 


\section{Chapter 6}

\section{"We are no Limburgers": Feeling in and out of place in Limburg}

\section{Introduction ${ }^{42}$}

On July 3, 2012, I was hanging around the city center of Roermond. Up until then my morning had not been very successful: I lacked the courage to approach people and, when I finally did, most people seemed unwilling to talk to me. I decided to take a lunch break and sat down on a bench on Munsterplein plaza (see Figure 6.1 for its location):

Figure 6.1: Google Maps screenshot of the city center of Roermond with the plaza of Munsterplein highlighted (Image by Google Maps, courtesy of Google Maps).

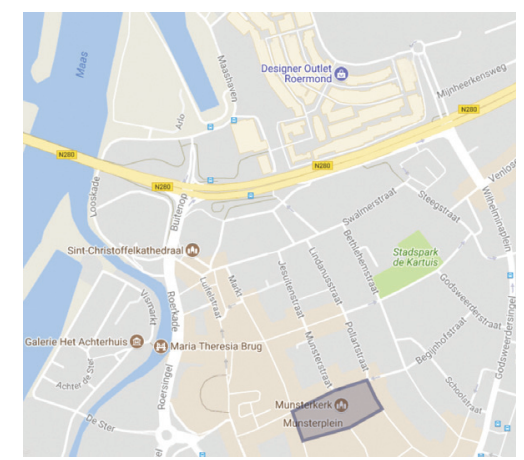

Here I am, sitting on a bench and feeling desperate, having temporarily given up hope after a morning of wandering around in Roermond and receiving strange looks from the people I have tried to talk with. This 'hanging around' by anthropologists can make a person feel very insecure. But one has to start somewhere... Luckily, it is a sunny day in July and the central plaza, Munsterplein, looks beautiful: the small cobblestones lie in the shade provided by the green trees that surround the plaza; the terraces of the cafes are full; and the Roman-Gothic church of Munsterkerk proudly stands amidst all this. I take out my lunch and, while eating, I observe - as befits a true anthropologist.

A man sits down on the bench in front of me, together with his little white dog. He greets another man walking by, and they start a conversation. While listening in on their conversation with my linguistic-anthropologically trained ears, my interest is piqued: the man with the dog uses a mix of Dutch and a dialect from Limburg, and the other man responds in a Dutch that I associate with Limburg, due to his use of what is popularly known as a 'soft g,' referring to velar voiced and voiceless fricatives. The men do not seem to be in a hurry, which encourages me to approach them; it seems they might have the time available to talk with me. And they do!

(Field notes, July 3, 2012)

\footnotetext{
42 For this chapter, I use parts of my paper published in the Dutch anthropological journal Etnofoor (Thissen 2013). With special thanks to the editors from Etnofoor for letting me use the paper in my dissertation.
} 
As usual, fieldwork opportunities tend to present themselves when least expected or, in this case, when the ethnographer has lost all hope for a while. My encounter with David and Zeegert, whose names are fictitious for ethical reasons, is a telling example of this. After the men provided their consent to audio-record them, I told them that I investigated how people feel at home in Roermond and what role language and culture play in these feelings. In reaction to this, both men immediately claimed "wij zijn geen Limburgers" ("we are no Limburgers"). The man sitting on the bench while holding onto the leash of his little white dog lying at his feet was David, originally from The Hague (located in the midwest of the Netherlands, see Figure 6.2).

Figure 6.2: Map of the Netherlands with

The Hague, Zwolle, and Roermond highlighted.

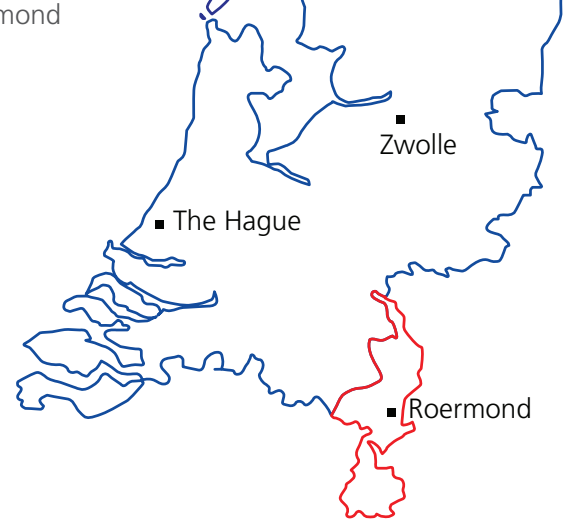

At the time of the conversation, David was 81 years old. He had been living in Roermond for approximately 45 years (and approximately 67 years in Limburg) and had worked as a coal miner, a construction worker, and a worker at a roof tile factory. The man talking to him was Zeegert, originally from Zwolle (which is located in the mideastern part of the Netherlands, see Figure 6.2) and 54 years old at the time of the conversation. He had been living in Roermond for 45 years and used to work as a market vendor throughout the province of Limburg. While I stood next to Zeegert in front of the bench, Zeegert proudly showed off the laminated and enlarged photographs that he had taken of (touristic) attractions and highlights of Roermond. It is with these men that I had a talk about feeling in and out of place in Limburg. ${ }^{43}$

The conversation left me puzzled: how come these two men who had been living most of their lives in Limburg (David 67 years and Zeegert 45 years) still felt out of place? By examining their language practices, I show that it is not as clear-cut as the men first claimed; they seemed to engage in ambivalent processes of place-making within Limburg and Roermond, which, I argue, seemed to express being in place and feelings of belonging as well as being out of place and feelings of unbelonging. I will analyze the men's use of linguistic forms and the social meanings produced by these in order to unravel how

\footnotetext{
${ }^{43}$ See Figure 2.2 in Chapter 2 for an overview of the dataset that was the result of the encounter with David and Zeegert.
} 
the men gave meaning to the places they lived in and their interactions with others. In so doing, it becomes clear how the men engaged in ambivalent processes of linguistic place-making in relation to Limburg and Roermond and how these, at the same time, (re) produced politics of (un)belonging based on different oppositions.

Section 6.1 carefully examines the men's use of linguistic forms and the social meanings embodied in them. Sections 6.2 and 6.3, respectively, deal with the men's processes of place-making and the constructed politics of (un)belonging. The conclusion summarizes the insights of this chapter while preliminarily reflecting on what this research case adds to the insights from Part I.

\section{Sociolinguistics of distribution}

Figure 6.3 presents a map by Van Oostendorp (2011: 152) that depicts the spread of the velar and uvular fricative within the Netherlands. For the purposes of this dissertation, only the pink and green colors are important since these, respectively, indicate the use of a uvular voiceless fricative (which Van Oostendorp refers to as 'hard g' and northern standard) and velar voiced and voiceless fricative (which Van Oostendorp refers to as 'soft $\mathrm{g}^{\prime}$ and southern standard). The combined pink and green stripes suggest that inhabitants of the areas below the 'big rivers' of the Netherlands in the southern provinces of NoordBrabant and Limburg and a small eastern part of the country are familiar with the use of both the voiced and voiceless velar and the voiceless uvular fricative. Even though Figure 6.3 reveals only two green areas where a 'soft $g$ ' is exclusively used, the process of enregisterment resulted in the general idea in the Netherlands that the 'soft $g$ ' is associated with the south of the Netherlands. In Figure 6.3, I circled David's place of birth, The Hague ('DH' on the map), and Zeegert's place of birth, Zwolle ('Zw' on the map). This shows that both cities are located in an area where the uvular fricative is commonly used.

Figure 6.3: Map of the Netherlands depicting the distribution of velar and uvular fricatives (taken from Van Oostendorp 2011: 152) with The Hague, Zwolle, and Roermond highlighted.

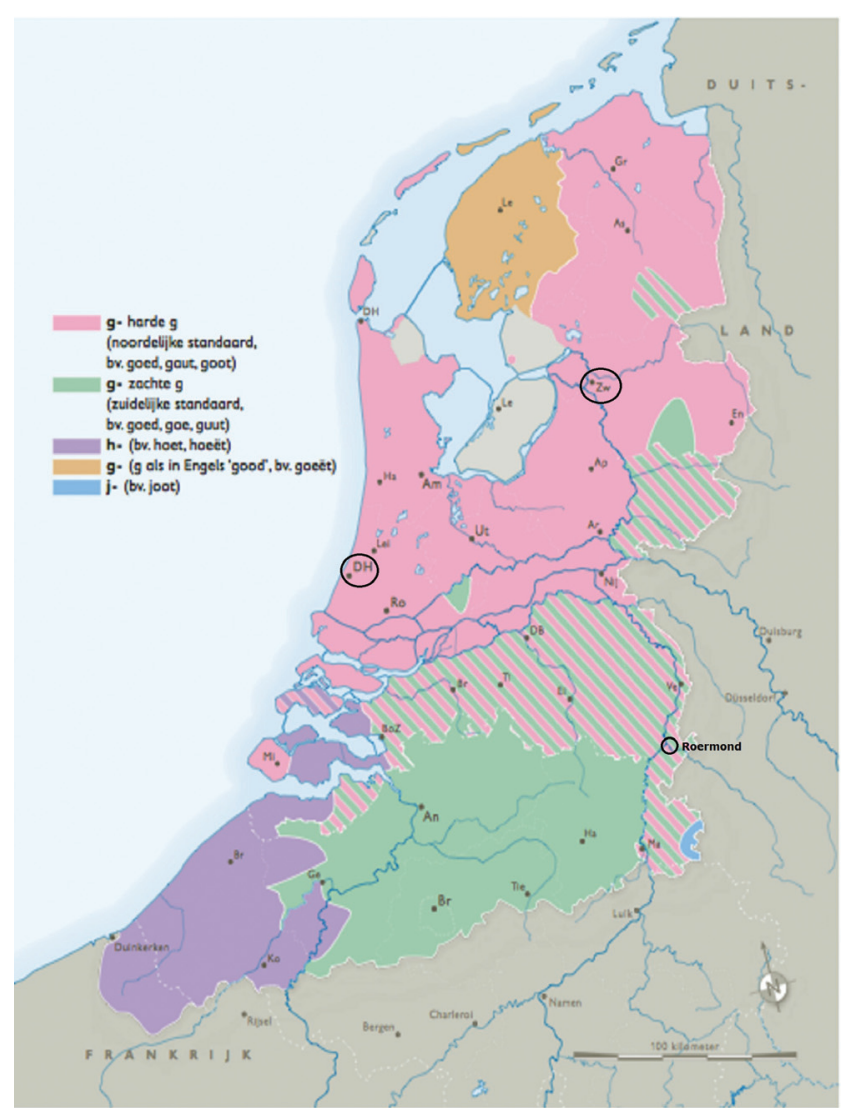


The map in Figure 6.3 is an example of what Blommaert (2010: 5) calls the sociolinguistics of distribution. This strand studies language in a horizontal and stable place and tries to conventionalize languages and linguistic forms (ibid). In this strand (as in dialectology), the use of linguistic forms is connected to a fixed place (Chambers and Trudgill 1980). Moreover, this strand assumes there are fixed ties between a person's language or use of linguistic forms, place, and body (Quist 2010: 646). In other words, a person born in one place has a particular identity and therefore has a particular language and belongs to a particular place. Sociolinguistics of distribution essentializes people and their linguistic behavior in its construction of 'the authentic speaker' of a particular area (Coupland 2003). This strand therefore reproduces language ideologies that imagine a social group or language as homogeneous, disregarding their internal variation (Gal and Irvine 1995: 974). I agree with Quist (2010: 646) that the sociolinguistics of distribution does not reflect the everyday realities of cultural and language practices that challenge fixed ties of language, body, and place.

\subsection{The language practices of David and Zeegert}

My conversation with David and Zeegert could be regarded, in the terminology of Goffman, as a 'talk' that is "naturally bounded, ritually bracketed (opened and closed), and displayed in bodily orientation" (Goffman 1981: 130-131). Our talk was bounded and ritually bracketed in the sense that there were three persons (including myself) who (after I approached them) engaged in a joint conversation that ended when Zeegert left. After that, the talk was continued by two persons (David and me) and ended when both David and I went our own ways. Both talks, with and without Zeegert, were displayed in our bodily orientation, since we faced each other while talking: before Zeegert left, Zeegert and I both stood in front of David, who sat on the bench; after Zeegert left, I joined David on the bench while continuing our conversation.

I will make use of the International Phonetic Alphabet (IPA) to describe the difference between the uvular voiceless fricative and the velar voiced and unvoiced fricative, also known in the Netherlands as 'hard' and 'soft g,' respectively. Aside from the singsong intonation (cf. Hagen and Giesbers 1988), the pronunciation of the 'soft $\mathrm{g}$ ' is generally associated with accents in Dutch in Limburg (see Cornips et al. 2012; Grondelaers et al. 2010; Thissen and Cornips 2015).

Transcription conventions velar and uvular fricatives

[y] velar voiced fricative in onset position of syllables (as in reit 'goat' and Limburyer 'Limburger'); soft sounding ' $g$ '

[x] velar and unvoiced fricative in code position of syllables (as in lax 'laugh'); soft sounding ' $c h$ '

[X] uvular voiceless fricative; hard sounding ' $g$ '

In this chapter I will show how this distinction between uvular and velar fricatives became relevant in the encounter with David and Zeegert. ${ }^{44}$

\footnotetext{
${ }^{43}$ I thank Ben Hermans and Maartje Giessen for their patience and help in explaining the IPA transcriptions for uvular and velar fricatives and their distributions. I alone am responsible for any remaining errors.
} 
In Extract 1, Zeegert introduced himself to me, while David commented on this, thereby guiding the conversation to the question of who is a real Limburger or not.

\author{
Extract 1 \\ 1 Zeegert Ik kom oorspronkelijk uit $\uparrow$ Zwolle. \\ I originally come from $\uparrow Z$ wolle. \\ 2 Lotte Zwolle. \\ Zwolle. \\ 3 David Z-zuus se waal, hè, je hebt, ehh, 个echte Limburgers tref je hier niet veul, \\ Y-you see, right, you have, uh, 个real Limburgers, you won't find them here, \\ 4 David $\quad$ want dae zie allemaal van \\ because they are all from \\ 5 Zeegert Veel import \\ A lot of imports \\ 6 David $\quad$ xxx import \\ $x x x$ imports \\ 7 Zeegert Daarom, wij zijn geen Limburgers \\ That is why we are no Limburgers
}

While the men were introducing themselves to me, it became clear that they had not been born in the province of Limburg and therefore did not consider themselves to be Limburgers. In the following sections, I examine the use of linguistic forms by David and Zeegert and the social meanings that these produced to show, eventually, how the men engaged in processes of place-making and politics of (un)belonging within Limburg and, more specifically, Roermond.

\title{
The different fricatives and code-switching between dialect and Dutch
}

Extract 1 already gives insight into the specific linguistic forms used by David and Zeegert. David used the uvular voiceless fricative [x] associated with Hollandic speech while he at the same time code-switched between linguistic forms associated with dialect from Limburg and Dutch. On the other hand, Zeegert used the velar voiced fricative [y] associated with a Limburgian accent in Dutch speech.

When Zeegert told me he originally came from Zwolle, David reacted as follows in Lines 3 and 4 (linguistic forms that are enregistered as dialect forms are transcribed in italics):

Extract 1

3 David Z-zuus se waal, hè, je hebt, ehh, $\uparrow$ [x]te Limbur[x]ers tref je hier niet veul, y-you see, right, you have, uh, $\uparrow$ real Limburgers, you won't find them here,

4 David $\quad$ want dae zie allemaal van because they are all from

In Line 3, David used the uvular voiceless fricative $[x]$ in the Dutch utterance "echte Limburgers" ("real Limburgers"). In addition, he code-switched between dialect and Dutch and, as upcoming extracts will show, also between the velar voiced and voiceless fricative $[\gamma]$ and $[x]$, respectively. In Lines 3 and 4, dialect forms are: zuus se waal [zu:s sø wa:I] (you see) instead of zie je wel [zi: jə wعl] in Dutch, veul [vœl] (much) instead of veel [ve:l] in 
Dutch, and dae zie [dع: zi:] (they are) instead of die zijn [di: zein] in Dutch. In Line 4 David also code-switched between Dutch and dialect; for example, if he had used only dialectal forms, then it would have been the Dutch allemaal [aløma:I] (all) instead of dialect allemaol [alømo:I] and dialect dae zie [d\&: zi:] (they are).

Zeegert, on the other hand, used Dutch in Lines 1 and 5 and pronounced this with the velar voiced fricative $[\gamma]$, as becomes clear from Line 7 :

\author{
Extract 1 \\ 1 Zeegert Ik kom oorspronkelijk uit $\uparrow Z$ wolle. \\ I originally come from $\uparrow Z$ wolle. \\ 5 Zeegert Veel import \\ A lot of imports

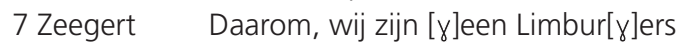 \\ That is why we are no Limburgers
}

If Zeegert had chosen to use dialect in Lines 1, 5 and 7, he would have used ich [IX] ' $I$ ' instead of $i k$ [IK] in Dutch. Further, if Zeegert had used the dialect associated with Roermond, he would have pronounced oet [u:t] 'from' instead of Dutch uit [œyt] and veul [vœl] 'much' instead of Dutch veel [ve:I]. However, Line 7 shows that Zeegert also used the velar voiced fricative [y], which is associated with accents in Dutch in Limburg, when he claimed

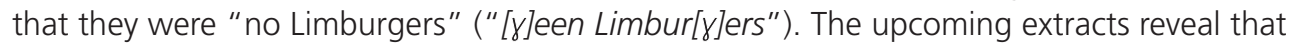
Zeegert only used forms that are enregistered as Dutch but with characteristics that indexed an accent associated with Limburg (cf. Grondelaers et al. 2010; Hagen and Giesbers 1988). The next section elaborates on the social meanings of these linguistic forms and the way that the use of these linguistic forms challenges static connections between language, place, and body.

\title{
Challenging language-place-body connections by using language as a resource
}

Language is - besides many other indicators (such as visual images) - one of the richest resources for the production of social meaning, since it is dual in nature: language has referential as well as social meaning (Bucholtz and Hall 2004). The word 'tree' has referential meaning in that it refers to the object of a tree, yet the manner that we interpret someone's pronunciation of the word 'tree' may reveal the social meaning of language and with what characteristics we associate that person's pronunciation. As part of meaning-making (semiotic) processes, linguistic forms can be powerful tools for people to align with or distinguish themselves from others (ibid). Ahearn (2012: 17) therefore argues that "questions about social relations and cultural meanings can best be answered by paying close attention to language." This would seem to demand a close examination of the social meaning of the men's language practices; how did their use of particular linguistic forms provide insights into the ways they aligned with or distinguished themselves from particular places or social groups (cf. Bucholtz and Hall 2004; Eckert 2008)?

In Chapter 1 I explained how particular linguistic forms are generally associated with the south of the Netherlands, and Limburg in particular, such as the velar fricative, melodious and singsong intonation, and dialect (Hagen and Giesbers 1988: 32). According to Eckert (2008), linguistic forms have a so-called indexical field, a range of possible social meanings, depending on the context and the interpreter. Besides the indexical association 
of the velar fricative and dialect with a place (the south of the Netherlands and Limburg), these forms also evoke social meanings, or stereotypes, about their users. Depending on the interpreter and his or her location, people having a melodious intonation in their Dutch, pronouncing the velar fricative and dialect may be perceived as 'Limburgers,' who are Catholic, convivial, backward, less intellectual, rural, and celebrate carnival (Cornips 2013: 135-136; Hagen and Giesbers 1988; Mathijsen 2011: 19-20). Further, the voiceless uvular fricative, as used by David, is on the one hand indexical of areas in the north of the Netherlands while also potentially evoking stereotypes about 'Hollanders,' who are - depending on the interpreter - rude, cold, stingy, arrogant, urban, efficient, and developed (Mathijsen 2011: 20, 23). The language practices of David and Zeegert are thus up for different interpretations; they used linguistic forms that are indexical of Limburg and, in David's case, 'Holland' as well.

Extract 1 showed that daily language practices are far more ambiguous than one might expect on the basis of the map illustration in Figure 6.3. David's use of the uvular fricative affirmed indexical expectations, since this pronunciation is associated with the part of the Netherlands where David's birthplace, The Hague, is located. Yet his use of the velar voiced and voiceless fricatives and dialect undermined indexical expectations, since these are usually associated with the south of the Netherlands. On the other hand, Zeegert pronounced the velar fricative, a linguistic form that, according to the map in Figure 6.3, people born in Zwolle would usually not use. These data challenge the indexical expectation of how a person born in a particular place would speak according to that place and complicate fixed ties between language, place, and body (cf. Quist 2010). Instead, David's and Zeegert's use of linguistic forms exemplified how people, in their daily interactions and activities, engage in languaging. Languaging refers to the use of language as a resource from which people draw specific linguistic forms depending on the communicative goals, situations, places, and the moments in their lives (cf. Jørgensen et al. 2011). In accordance with Wiese (2013: 3), David and Zeegert created a pond from the pool of competing linguistic forms coming from different sources in contact situations. Furthermore, the language practices of David and Zeegert support the idea that areas perceived as being peripheral are just as linguistically diverse as centrally perceived areas (cf. De Lima 2012; Kelly-Holmes and Pietikäinen 2015).

Although the languaging practices of David and Zeegert challenged the fixed connections between language, place, and body, people themselves may still regard these aspects as indeed very much linked (cf. Quist 2010). Contrary to the common indexical meaning, David and Zeegert did not interpret their own speech as automatically forging feelings of Limburgian belonging or 'Limburgerness' (see Chapter 3), mainly because they were born elsewhere. They explicitly drew a boundary between themselves ("we are no Limburgers") and Limburgers, since they were born elsewhere in the Netherlands ("I originally come from Zwolle" and "a lot of imports"). In this, David and Zeegert indeed seemed to presume a fixed connection between one's place of birth, identity, and belonging: if you were not born in Limburg, you are not a Limburger. Of course, the fact that they claimed this is probably also the result of what other people have said to them in the past. It suggests that people may very well root themselves in places and groups to cope with the perceived increase of diversity in current societies (cf. Cresswell 2009; Duyvendak 2011; Olwig and Hastrup 1997). As a result, boundaries may be linguistically constructed between 'us' and 'them'; in this case, "real Limburgers" and "no Limburgers." While people's ideological beliefs tend to bind these aspects together in a static way, people's actual 
language practices are dynamic, context-dependent, multi-layered, and, above all, ambiguous. Bearing this in mind, it is important to examine how people engage in place-making instead of assuming fixed or untied links between language, body, and place.

\subsection{Being both in and out of place}

David and Zeegert used linguistic forms that evoked a sense of place and identity (cf. Johnstone 2013a), namely Limburg and 'Limburgerness,' while, at the same time, they explicitly claimed not to be Limburgers. In order to understand this, I examine how both men engaged in place-making processes and appropriated the places they are living in by attaching social meaning to space through linguistic and cultural practices, thereby transforming space into a lived place (cf. Cresswell 1996; Pred 1985). I will point out how David and Zeegert endowed the space of Limburg and Roermond with social meaning and how they related to these spaces both as in and out of place.

Two forms of place-making influence people's place-making practices: on the one hand there are the broader place-making processes that link entire locations (villages, cities, regions, countries) with particular linguistic and cultural resources and ideological beliefs that might be stereotypical; on the other hand, people engage in and give shape to more individual place-making processes that arise out of their own practices, activities, and interactions with others in everyday situations and locations (see Section 1.5 of Chapter 1). As a result of the first form of place-making, people may link particular linguistic forms to a particular location, such as the velar fricative and use of dialect associated with the province of Limburg as a whole. The second form of place-making is more about how people actually appropriate locations, feel at home (or not) in a particular location, and shape ideas of appropriate behavior and norms within that location. The two forms of place-making understandably are closely related to each other in that the place-making processes directed at locations as a whole influence the ways that people 'on the ground' appropriate the locations they inhabit in their daily lives. Language plays a vital role in disclosing our "being-in-the-world" (Csordas 1994: 11). This 'being-in-the-world' form of place-making helps in grasping the ways that David and Zeegert related to and engaged with the location they live in and the people they interact with; my conversation with both men showed that the study of language practices and place-making also addresses how people connect with, as well as disconnect from, others in a particular location.

Place-making as 'out of place'

When examining how the language practices of David and Zeegert disclosed their beingin-the-world (cf. Csordas 1994), Lines 3 and 7 of Extract 1 show that they distanced themselves from "real Limburgers" by explicitly asserting this:

\section{Extract 1}

3 David Z Z-zuus se waal hè, je hebt, ehh, $\uparrow$ e[X]te Limbur[X]ers tref je hier niet veul, Y-you see, right, you have, uh, $\uparrow$ real Limburgers, you won't find them here,

7 Zeegert Daarom, wij zijn geen Limbur[y]ers

That is why we are no Limburgers 
These lines demonstrated that there was a discrepancy between the men's language practices and their affiliation with Limburg that is indexed by David's use of dialect in Line 3 and Zeegert's use of the velar fricative in Line 7. It is here that it becomes clear how the two forms of place-making processes relate. Even though the men used forms that are usually enregistered as dialect or an accent from Limburg, David and Zeegert explicitly claimed not to be Limburgers. Their daily place-making process shows that this does not mean that the men recognized themselves in the dominant (stereotypical) conceptions of place-making processes that link particular linguistic forms with Limburg.

During the conversation I interpreted David's and Zeegert's claims of not being Limburgers as if they were saying that they were not 'good enough' to participate in my research. In Extract 2 below, I therefore tried to convince them that this was certainly not the case. In answer to Zeegert's question what my research was about (Line 2), I told him that I studied how people feel at home in Roermond and that they were perfect examples, especially since Zeegert was taking photographs of the city as if it were his own city (Line 6). I deliberately chose these words "as if it is your own city" to see how Zeegert would react to this.

\section{Extract 2a}

1 Lotte $\quad$ Nee, maar dat maakt niet uit, jullie zijn inwoners van Roermond, to[x]? No, but that does not matter, you are inhabitants of Roermond, right?

2 Zeegert En wat [r]a je onderzoeken dan precies? And what are you going to investigate exactly?

3 Lotte $\quad$ Eh, nou, hoe mensen zich thuis [y]aan voelen in Roermond, Uh, well, how people make themselves at home in Roermond,

4 Lotte Dus daarom zijn jullie hele mooie voorbeelden, jullie wonen hier allang, That is why you two are great examples, you have been living here for a long time,

5 David $\quad=$ Ja, ja $=$ Yes, yes

6 Lotte $\quad$ Maar u maakt foto's van de stad alsof het uw ei[y]en stad is, But you take photographs of the city as if it is your own city,

In Lines 7 and 8 below, Zeegert immediately explained what parts of the city he captured with his camera, showing me some examples at the beginning of our conversation. He described in Lines 10 to 12 that he certainly had a connection to the city, since it is beautiful, but revealed to me that the people were difficult to deal with - that is, "the real Limburgers who are born here." David immediately (hence the latching sign '=') agreed with him by saying that "real Limburgers are no easy-going people." In Lines 11 to 15, the men built upon the boundary that had already come to the fore in Extract 1: they continued distancing themselves from "real Limburgers." In this part, the men seemed to relate to the larger process of place-making that constructs Limburg as a region with specific characteristics. The men reproduced existing stereotypes about Limburgers who make up a rather closed 'community' where outsiders can hardly ever join - hardly ever, because Extract 3 will show that David did join in earlier days. In Line 15, Zeegert again explicitly separated the two of them from Limburgers, by adding to David's remark that "we cannot join them." Extracts 1 and 2 suggest that David and Zeegert engaged in a place-making process that put them out of place in Limburg by explicitly claiming they were "no Limburgers" (Extract 1, Line 7) and that "real Limburgers" were difficult to deal with (Extract 2b, Line 11). 


\section{Extract 2b}

7 Zeegert = Van de bezienswaardi[y]heden, alles wat,

$=$ Of the attractions, everything that is, [loud traffic]

8 Zeegert van het [r]emeentehuis, van de kathedraal, van, van kunst, van vanalles, hè, of the city hall, of the cathedral, of, of art, of everything, right,

9 Lotte Ja, maar voelt $u$ wel een soort verbond, Yes, but do you feel some kind of connection,

10 Zeegert = Verbonden met de stad, ja, de stad is $\uparrow$ mooi, $=$ Connected to the city, yes, the city is $\uparrow$ beautiful,

11 Zeegert ${ }^{\circ}$ En, eh, (.1) de mensen zijn wat moeilijk in de om[r]ang vin ik, ${ }^{\circ}$ And, uh, (.1) the people can be difficult to deal with, I find,

12 Zeegert De $\uparrow$ e[x]te Limbur[y]ers, die hier [y]eboren zijn, The $\uparrow$ real Limburgers, who are born here

13 David = Ja: ik denk 't ook dat de $\uparrow$ e[X]te Limbur[X]ers, $=$ Ye:s I also think that the $\uparrow$ real Limburgers,

14 David dat dat $x x x \uparrow[x]$ een [x]emakkelijke mensen zeen that that $x x x \uparrow n o$ easy-going people are

15 Zeegert = zijn moeilijk $=$ daar komen wij niet (.) bij $=$ are difficult $=$ we cannot $($.$) join them$

Linguistic analysis of David's utterances shows that he used the uvular voiceless fricative when he referred to echte Limburgers (real Limburgers) in Extract 1 (Line 3) and Extract $2 b$ (Line 13) and when he claimed they were geen gemakkelijke mensen (no easygoing people) in Extract 2b (Line 14):

\section{Extract 1}

3 David Z-zuus se waal hè, je hebt, ehh, $\uparrow$ e[x]te Limbur[x]ers tref je hier niet veul, Y-you see, right, you have, uh, 个real Limburgers, you won't find them here,

\section{Extract $2 b$}

13 David = Ja: ik denk 't ook dat de $\uparrow$ e[X]te Limbur[X]ers, $=$ Ye:s I also think that the $\uparrow$ real Limburgers,

14 David dat dat $x x x \uparrow[x]$ ]een [X]emakkelijke mensen zeen that that $x x x \uparrow n o$ easy-going people are

In this interaction, David used the uvular voiceless fricative that generally indexes 'an outsider' within Limburg. In doing so, David strengthened the boundary between him, the outsider, and them, the real Limburgers. Woolard (2008: 436-440) argues that language ideologies lie at the bottom of people's use of language in daily lives. She argues that awareness of underlying language ideologies about a particular linguistic form may lead to linguistic variation. People may do this either to go against the ideology or to be in line with it. In this case, with his use of the uvular voiceless fricative, David tried to be in line with the stereotype that this fricative is indexical of outsiders in Limburg. This seems to suggest that he did not want to be considered as someone coming from Limburg, despite also using dialect forms that generally index someone from Limburg. In doing so, I believe he further construed an opposition between "the real Limburgers" - them - and the outsiders - us. 
These extracts show that place-making processes are not necessarily 'positive' in the sense that place-making provides a comfortable feeling of being at home or in place. The study of place-making processes does not simply assume this but examines how people relate to particular locations in their lives. As such, place-making can also very well result in feelings of being out of place, as the case of David and Zeegert illustrates. But this is not exclusively the case, as I will argue in the following section, since both men's place-making processes were quite ambivalent.

\section{Place-making as 'in place'}

Up until now, David and Zeegert made it clear that they did not identify as Limburgers and felt out of place. However, their language and cultural practices seem to suggest the men acted in place as well.

Until now I have discussed how that David and Zeegert used language as a resource in employing particular linguistic forms that they had acquired during their lifetimes by living in different places within the Netherlands. I also showed how David's use of the uvular voiceless fricative strengthened the boundary between him, an outsider, and "real Limburgers." David, however, also opted for the use of dialect. In Extract 3a, I asked David how come he used dialect words. David explained in Lines 2 and 3 how he had learned dialect while living in Thorn for 22 years, a village near Roermond also known as "the white village" (to which Zeegert and I referred in Lines 6 and 7).

\section{Extract 3a}

1 Lotte $\quad$ En $\mathrm{u}$, want u spreekt $\uparrow$ wel wat dialect woorden?

And you, because you do use dialect words?

2 David $\quad=\uparrow$ Ja maar weet je wie dat komt omdet i[X], eh, veul (.)

$=\uparrow$ Yes, but do you know why, because I, uh, many,

3 David I[X] -i[X] höb in $\uparrow$ Thorn [X]ewoond, hè, 22 jaar,

I-I have lived in Thorn, right, 22 years,

4 Zeegert $=$ Ja ja, $=$ dat zal,

$=$ Yes yes, $=$ as if

5 David En op een [X]e[X]even moment,

And at one point

6 Zeegert Het witte $\uparrow$ stadje

The white town

7 Lotte Het witte $\downarrow$ dorp

The white village

From Extract 3b, Line 8 onwards, David started telling an anecdote from the time he was nominated as prince carnival of Thorn. Being nominated as prince carnival is generally perceived as a great honor and a once-in-a-lifetime opportunity (see Chapter 3 ). The fact that David told this story shows his awareness that being a prince carnival was something to be proud of and to tell people about but, more important, it suggests that David knew that carnival is generally perceived as a characteristic of Limburg in which the use of dialect is deemed vital (remember the quote of De Katers member Wim in Chapter 4) and may even be a tradition that makes the difference between 'real' Limburgers and 'outsiders.' David narrated in Lines 11 and 12 that his reigning period as prince was not undis- 
puted, because some people knew he was a "Hollander." In Line 13, David recounted how he informed the president (similar to a monarch) of the carnival association that a certain man was intimidating him by telling him that he, "a bald Hollander," would never become a prince carnival (Lines 14 and 15). David then asked Zeegert whether he recognized this as well, by using the dialect form witse (you know) in Line 16. In Lines 17 and 19, Zeegert affirmed that it was a shame, but that it was just the way things go. David continued his story, saying that he did not let this bother him, but that it was nonetheless a hateful event (Line 18). In Line 22, David concluded his story by saying that he nevertheless became a prince, and then followed it with a triumphant laugh.

\section{Extract 3b}

8 David Daar ben ik zelf ook prins $\uparrow$ carnaval [y]ewees in Thorn I was prince carnival myself in Thorn

9 Lotte $\quad \uparrow E[\gamma]$ twaar? $\uparrow$ Really?

10 David Ja:!

Ye:s!

11 David Maar dat z/, da hatse altied $\uparrow z e u k e r s$ tussen, hè, But it W/, you always have $\uparrow$ (searchers)/(naggers), right, $\%$ [unsure what 'zeukers' refers to in this sentence]

12 David want ze wisten dat $i[x]$ een Hollander $\downarrow$ was (.) because they knew that I $\downarrow$ was a Hollander (.)

13 David En toen $z a[x]$ ik dat, eh, te[y]en de president: And then I told that, uh, to the president:

14 David dae man dae moet mi[ $x]$ neet, dae za[X] altied tea[y]e mi $[x]$ that man does not like me, he always tells me:

15 David Doe waers nooit prins, doe $\uparrow$ kale Hollander.

You are never going to be a prince, you $\uparrow$ bald Hollander.

16 David [spreekt tegen Zeegert] Witse wat 't was, hè? xxx [talking to Zeegert] You know what, right? xxx

17 Zeegert $\quad=J a, j a, j a, j a$ =Yes, yes, yes, yes

18 David Maar ik trok mi[x] dao neet veul van aan, maar het was $\uparrow$ hate, $\uparrow$ hatelijk, hè, But I did not take it personally, but it was $\uparrow$ hate, $\uparrow$ hateful, right,

19 Zeegert Ja, ja, ja, dat is jammer, dat is [r] $\mathrm{\gamma}$ ewoon, dat is wel zo, Yes, yes, yes, it is a shame, that is the way it goes, it is true

20 David Ja, maar dat $\uparrow$ is Yes, but it $\uparrow$ is

21 Zeegert Dat krij/ dat is, dat is [y]ewoon You get/ it is, it's normal

22 David Ik ben toch even [X]oed prins carnaval geworden I nevertheless did become prince carnival [laughs triumphantly]

While telling this story, David used both the velar and uvular fricative and dialect. Extract 3b demonstrates how David used language as a resource or pool (cf. Wiese 2013) to draw from and to acquire bits and pieces of the enregistered dialect and accent of Limburg depending on the communicative goals and context (cf. Jørgensen et al. 2011). David 
thereby serves as a case in point to exemplify why people employ linguistic variation in order to, first, be in line with or challenge language ideological expectations (cf. Woolard 2008), and, second, to identify with or distance themselves from a particular place, group, or community (cf. Eckert 1989; Labov 1963). Since David was aware of the fact that he was perceived as a Hollander, probably including the accompanying negative stereotypes, he attempted to identify with Limburg by increasing the use of specific linguistic forms that are indexical of 'Limburgerness.' This stands in contrast with Extract 1, where he was clearly distancing himself from Limburgers by using the uvular voiceless fricative and Dutch. It seems that David was putting forth extra linguistic effort into defending himself as a 'Limburger' by using the velar voiced and voiceless fricative and dialect compared with his other utterances, since someone had disputed his suitability to become a prince carnival. This is especially clear in Lines 14 and 15 (repeated below), where David retold what he had said to the president of the carnival association: 45

\section{Extract 3b}

14 David dae man dae moet mi[x] neet, dae za[x] altied tea[y]e mi[x]: that man does not like me, he always tells me:

15 David Doe waers nooit prins, doe $\uparrow$ kale Hollander. You are never going to be a prince, you $\uparrow$ bald Hollander.

David also seemed to relate, to a certain extent, to Limburg by engaging in practices that are commonly associated with the province. Extract 3 demonstrates that David embraced the place where he lives in two ways. First, he embraced particular cultural practices that are common in Limburg, such as becoming part of a local carnival association and being announced as the association's prince carnival. Second, David added linguistic forms that are generally associated with Limburg to his own linguistic repertoire. Extract 3 shows that David's process of place-making not only put him out of place in Limburg and in opposition with "real Limburgers," but that his cultural and language practices suggested that he was also in place in Limburg. Extract 3b nevertheless follows up on the earlier claim made in Extract $2 \mathrm{~b}$ about its being hard to join "the real Limburgers"; the prince carnival anecdote shows that David succeeded in joining 'them,' but that it was indeed difficult due to others who opposed him.

Extract 1 revealed that Zeegert used the velar voiced fricative in his Dutch and that his intonation sounded melodious (cf. Hagen and Giesbers 1988). This is not remarkable given that he had been living in Limburg since he was a young boy and had presumably adapted his linguistic repertoire to his surroundings. Unlike David, Zeegert did not use linguistic forms that are enregistered as dialect, yet Extract $3 b$ shows that Zeegert understood perfectly well what David meant when using the dialect form witse (you know) in Line 16. In the same way as David, Zeegert embraced the velar fricative, the linguistic form indexical of Limburg, even though he was originally from an area where the uvular voiceless fricative is widespread.

Moreover, Zeegert claimed to be an outsider in Limburg who could not fit in due to the difficulties of contact with "the real Limburgers who were born here" (see Extract 2, Line 12). In reaction to the prince carnival anecdote by David, Zeegert claimed:

\footnotetext{
${ }^{45}$ It is plausible that David was literally retelling what he said to the president of the carnival association, thereby using the exact words he had used when talking to the president.
} 


\section{Extract 4}

1 Zeegert =Wij zijn buitenstaanders en dat hou je, dat blijf je,=

$=$ We are outsiders, that's the way it is, you will stay an outsider, $=$

2 Zeegert daar kan je niks aan doen, [ac]\{of veranderen\},

you cannot help it, [ac] \{or change it\},

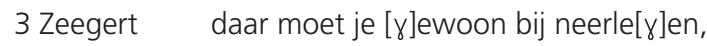
you just have to accept it,

4 Zeegert Als je dat kan, dan ben je, dan voel je jezelf wel thuis hier If you can, then you are, then you will feel at home here.

For the first time, in Line 1 of Extract 4, Zeegert labeled himself and David as buitenstaanders (outsiders), thereby emphasizing their feeling of being out of place. Yet Zeegert did not let this bother him, and in Lines 1 to 3 he described the coping strategy that enabled him to deal with the predicament of being an outsider in Limburg; one just needs to accept that one cannot change this and that an outsider will always remain an outsider. Only then, Zeegert argued in Line 4, would one be able to feel at home or in place "here," referring either to Limburg and/or Roermond. In relation to his coping strategy, I asked Zeegert whether dialect played a role in feeling at home in Limburg. What follows is an explanation of how Zeegert put his coping strategy into practice in his daily life:

\section{Extract 5}

1 Lotte En ook dialect, is dat ook een (.) factor dat meespeelt daarin of? and the dialect, is that also a (.) factor that plays a role, or?

2 Zeegert Ja, dat speelt, Yes, it plays,

3 David $\quad=\underline{\text { Nou, eh, }}$ $=\underline{\text { Well, uh }}$,

4 Zeegert Ja, ik versta het [y]oed, maar, eh, dat speelt $\uparrow$ zeker een rol Yes, I understand it well, but, uh, it $\uparrow$ definitely plays a role

5 David als ze horen when they hear

6 Zeegert = $=\underline{k}$ wil d'r niet bijhoren, ik wil wel bij de stad horen, de stad is pra[x]tig.

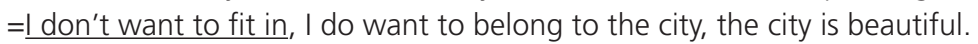

7 Zeegert $\quad$ 'maar niet bij de mensen dat hoeft voor mij niet ${ }^{\circ}$ 'but I don't want to belong to the people, there's no need ${ }^{\circ}$

8 David $=\mathrm{Nee}=$ $=\mathrm{No}=$

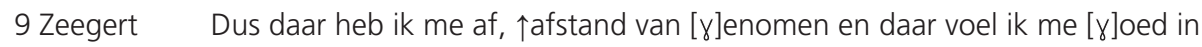
So of that I, I $\uparrow$ distanced myself from that and I feel good about it

When he talked about dialect in Extract 5, Zeegert claimed to understand dialect well (Line 4) but said he did not want to fit in. Then, in Line 6, he clearly drew a boundary between the people of Roermond and the city itself. From Line 7, it seems as if he was saying that he did not want to speak dialect, since he did not have the urge to belong to the people (a sentence he uttered in a softer voice, see ${ }^{\circ}$ in the transcript).

One could argue that he perceived speaking dialect as a prerequisite for interacting with 'them, the Limburgers.' Instead, he said he wanted to belong to the city, which he 
thought was beautiful. In order to feel at home or to make a place for himself within the city, he claimed to have distanced himself from the people of Roermond (Line 9). His hobby, taking photographs of the city, underlined his place-making within the city as a physical place. With this, he demonstrated how he felt in place in the location of Roermond an sich but out of place among 'its' people. This is in contrast with Smaldone (2006), who found that as people reside in a place for a longer time, they value their place attachment in terms of the social relations they have in that place, whereas people who have just moved somewhere mainly describe their place attachment in terms of environmental features. Even though Zeegert had been living in Roermond for 45 years at the time we met, he nevertheless did not refer to his social relations in this place; he even claimed to want to belong to the city and to cherish its environmental features but to explicitly unbelong among the people in Roermond.

As can be seen from the foregoing, the two forms of place-making processes relate to and influence each other. The broader place-making process whereby the region of Limburg is associated with particular ways of speaking and behaving seems to have influenced how David and Zeegert engaged with the places surrounding them in their daily lives. David in particular seemed to be highly aware of the social meaning indexed by his use of linguistic and cultural practices and forms. This exemplifies how daily place-making processes are influenced by indexical meanings that are the result of broader place-making processes.

Moreover, the men's place-making processes suggest that their initial explicit statement of being "no Limburgers," who were out of place within Limburg, was much more complicated when one examines their actual interactions and practices. This illustrates that place-making processes can be very ambiguous and out of line with the things people claim in the first place. Although David and Zeegert put themselves out of place within Limburg at first, I have shown that they also established themselves as being in place within Limburg and Roermond by employing particular linguistic forms and engaging in cultural activities. They nevertheless claimed to be outsiders within Limburg and Roermond. As such, their language practices disclosed their ambivalent being-in-the-world (cf. Csordas 1994).

In the following section, I relate this being in and out of place to politics of (un) belonging. I will show that ambivalent place-making processes influenced the men's ideas about (un)belonging, in which different oppositions of 'us' and 'them' were salient and recurred on different scales, thereby relating to some extent to the relationship between centers and peripheries.

\subsection{Recurring oppositions of (un)belonging}

\section{Examining politics of (un)belonging}

Aside from giving meaning to places with place-making practices, people at the same time fashion themselves and others through the construction of definitions of self and other, by which they try to fit into the existing relations, groups or oppositions within a place (cf. Eckert 1989; Feld and Basso 1996). The politics of (un)belonging, with its feelings and ideas about who and what are in and out of place, captures both the personal and intimate feelings of place-belongingness as well as interpersonal discourses about inclu- 
sion and, just as important, exclusion (cf. Antonsich 2010; Christensen 2009; Yuval-Davis 2006). David and Zeegert exemplify how "belonging is not that of an individual to a fixed community rooted in place, but rather, one in which a place becomes valuable to the individual" (Savage et al. 2005: 80). My conversation with David and Zeegert thus shows how 'place' plays an important role in the construction and experience of feelings of (un) belonging. Of course, multiple places can become valuable during a person's lifetime (ibid), David and Zeegert being two cases in point.

By making use of the tactics of intersubjectivity, as put forward by Bucholtz and Hall (2004, 2005), this section reveals various oppositions of 'us' and 'them' constructed by David and Zeegert and shows how they shifted between and reproduced different oppositions of belonging and unbelonging that referred to different center-periphery dynamics in their interaction with me. The intersubjective tactics "provide a more systematic and precise method for investigating how identity is constructed through a variety of symbolic resources, and especially language" (Bucholtz and Hall 2004: 370). The tactics consist of three pairs of conceptual tools: adequation and distinction; authentication and denaturalization; authority and illegitimation. These pairs can be used interchangeably (Bucholtz and Hall 2005: 599). For my research, these tactics illuminate the possibilities available to people to construct belonging and unbelonging, and the boundaries between groups of 'us' and 'them' that are created through the use of linguistic forms. Moreover, these pairs facilitate the examination of how (un)belonging is claimed, justified, and challenged in people's interactions.

The first pair, adequation and distinction, is a widely used pair of tools dealing with the demarcation of linguistic and cultural similarities and differences between groups of people or places. This principle is exemplified by the boundary David and Zeegert constructed between "the real Limburgers" (who were born in Limburg, are difficult, and no easy-going people) and "outsiders" (who are originally from elsewhere and cannot fit in). Bucholtz and Hall go beyond the adequation and distinction principle and include notions of authenticity and legitimacy in order to examine what is required to identify with a particular group or place.

The second pair of tactics, authentication and denaturalization, specifically focuses on how people "make claims about realness and artifice" (Bucholtz and Hall 2005: 601). Citing Bauman (1992: 137), Bucholtz and Hall describe authentication as comparable to traditionalization, in which art or antique dealers search for an art object's origin, thereby rendering its authenticity. In my case study, David's description, in which he presented his 22-year-long residency within the village of Thorn as the explanation for his taking up and using dialect, resembles this process of authentication in that it rendered legitimacy and realness or authenticity to his acquisition of dialect (cf. Bucholtz and Hall 2004, 2005). The tactic of authentication furthermore concerns ideas about ways of speaking and behaving that people may or may not perceive as 'genuine' or 'appropriate' in a particular situation, place, or group. The fact that I started my conversation with David and Zeegert in Dutch, not dialect, provides insight into my caution and the assumptions I already articulated in my mind about both men. I figured that the use of dialect would exclude Zeegert, whom I overheard only using Dutch forms in his speech prior to my approaching both men. Since David simultaneously used both Dutch and dialect forms in his speech, I decided to approach them in Dutch in order to include both men in the conversation.

While authentication is concerned with more essentialist authenticities, denaturalization is rather about non-essentialism (Bucholtz and Hall 2004: 386). In this sense, 
denaturalization operates to destabilize the essential claims of authentication and thereby subvert the ideological expectations. In accordance with Bucholtz and Hall, David and Zeegert were denaturalizing and subverting ideological expectations by using the velar voiced and voiceless fricatives that are, according to the map in Figure 6.3, not found in their places of birth, Den Haag and Zwolle.

The last pair, authority and illegitimation, refers to people's efforts to appropriate authority to identify with a particular place and to judge, or reject, others' identifications of belonging. As a result, someone's attempt to identify with a group or place may be illegitimized because he or she is judged as lacking certain requirements. In David's and Zeegert's cases, they took up authority to draw a boundary between themselves and Limburgers and to claim that they were outsiders, since they lacked the requirement of having been born within Limburg. Particular accents or particular looks can also be aspects upon which someone's belonging (mine in this case) is evaluated, judged, and illegitimized. In the following sections, I demonstrate how these tools were used by David and Zeegert while they related politics of (un)belonging to oppositions relating to different centerperiphery constellations: Limburg versus Holland; oppositions within Limburg; oppositions with Roermond.

\section{Center-periphery dynamics between Limburg and Holland}

The opposition between Limburg and 'Holland,' that constructed senses of 'Limburgerness' from 1867 onwards (cf. Knotter 2011), was reproduced by David and Zeegert in Extracts 1 to 3 . Both men felt out of place in Limburg, since they were born in 'Holland.' Furthermore, David's increased use of the velar voiced and voiceless fricatives and dialect in the prince carnival anecdote of Extract 3 indicated his awareness of existing language ideological stereotypes about "bald Hollanders," which motivated his linguistic variation as a way to resist those stereotypes (cf. Woolard 2008). When David's appointment as prince carnival was being questioned, because he was perceived as a Hollander, he tried to use forms that index the opposition between Limburg and 'Holland.' As a consequence, he used the uvular voiceless fricative that indexes 'Hollanders' less and used the velar voiced and voiceless fricative and dialect more, in order to be perceived as a 'Limburger.'

The following extract is another example of how this opposition between Limburgers and Hollanders was further reproduced by David and Zeegert.

\section{Extract 6}

\begin{tabular}{|c|c|}
\hline 1 Lotte & Zijn Limbur[y]ers direct of juist niet? \\
\hline & Are Limburgers blunt or not? \\
\hline 2 Zeegert & $\downarrow$ Nee, nee \\
\hline & $\downarrow N o$, no \\
\hline 3 Lotte & Helemaal niet? \\
\hline & Not at all? \\
\hline 4 David & Een $\uparrow$ Hollander wel \\
\hline & A $\uparrow$ Hollander is \\
\hline 5 Zeegert & Een Hollander wel! \\
\hline & A Hollander is! \\
\hline 6 Lotte & Ja: \\
\hline & Ye:s \\
\hline
\end{tabular}




\begin{tabular}{|c|c|}
\hline \multirow[t]{2}{*}{7 David } & Mijn moeder wel, hoor \\
\hline & My mother was, you know [car honking] \\
\hline 8 Zeegert & Een $\uparrow$ Amsterdammer is heel brutaal \\
\hline & An $\uparrow$ Amsterdammer is very bold \\
\hline $\begin{array}{l}9 \text { David } \\
107 \text { 7eegert }\end{array}$ & [laugns] \\
\hline & [ac] $[$ When they come here, they don't understand each other, \\
\hline 11 Zeegert & $\begin{array}{l}\text { een Limbur[y]er en, en vice versa. } \\
\text { a Limburger and, and vice versa. }\end{array}$ \\
\hline 12 Zeegert & $\begin{array}{l}\text { Amsterdammer, Amsterdammer, die zullen mekaar nooit verstaan, } \\
\text { Amsterdammer, Amsterdammer, they will never understand each other, }\end{array}$ \\
\hline 13 Zeegert & $\begin{array}{l}\text { want die zijn brutaal en dat vind ik ook. } \\
\text { because they are bold and I think so too! }\end{array}$ \\
\hline 14 Zeegert & Daarom woon ik liever hier, \\
\hline 15 Zeegert & 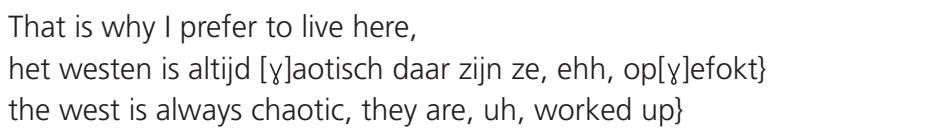 \\
\hline 16 David & $=\mathrm{Ja}$ \\
\hline & $=$ Yes \\
\hline 17 Zeegert & $\begin{array}{l}=\text { enzo een beetje door[y]edraaid (.) hier zit een versnelling minder. } \\
=\text { and so on a bit manic }(.) \text { people here take it easier. }\end{array}$ \\
\hline
\end{tabular}

My question about the bluntness of Limburgers stemmed from the stereotype that Limburgers never talk straightforwardly to a person when there is a problem (Knotter 2009; Mathijsen 2011). Due to my explicitly asking for their opinion on the bluntness of Limburgers, David and Zeegert related to the stereotypical ideas that are associated with people living in Limburg by stating that Limburgers are not blunt at all, but that Hollanders, on the other hand, are chaotic and worked up, whereas in Limburg people take it easier.

In Line 2 above Zeegert stated that Limburgers are not blunt - which is in line with the general stereotypes that exist about Limburgers. Without being prompted, David claimed that Hollanders (including his mother), in contrast, are blunt (Lines 5 and 7). In Lines 8 to 13 Zeegert agreed with that and added that people from Amsterdam and Limburgers cannot get along with each other because Amsterdammers (people from the Dutch capital of Amsterdam) are bold. It is remarkable to see here that Zeegert seemed to parallel Hollanders with people living in the national capital of Amsterdam. He then explicitly emphasized that he thought the same way about Amsterdammers (Line 13). Because of that, he stated that he preferred living in Limburg (Line 14). He eventually said, in Line 15, that he did not like the rush that runs "the West" (thereby referring to the Randstad area), with which David agreed immediately in Line 16. Zeegert concluded by saying that people in Limburg take it easier than in "the West."

As such, Extract 6 reproduces the previously mentioned stereotypes in an unexpected way. From this point forward, David and Zeegert seemed to evaluate Limburgers more positively than they did in earlier extracts. Although they felt out of place in Limburg, living in Limburg was preferred over living in "the West," and 'Hollanders' were negatively perceived as being bold, chaotic, worked up, and a bit manic. In contrast, Limburgers take life easier, according to Zeegert.

David and Zeegert illustrate that the opposition between Limburg and Holland, a 
result of the negative integration of Limburg into the nation-state (Knotter 2011), is still relevant and reproduced nowadays. I recognize the intersubjective pair of adequation and distinction (Bucholtz and Hall 2004, 2005) in this constructed opposition between Limburg and Holland. In Extract 6, Zeegert and, to a lesser extent, David found adequation with the perceived group of 'Limburgers' (who take it easier) as opposed to 'Hollanders' (who are chaotic). Common stereotypes are thereby reproduced and used to demarcate differences between the two perceived groups.

In addition to the intersubjectivity pair, Baumann's and Gingrich's (2004) grammars of identity/alterity - they deliberately use a slash sign to emphasize the interdependency between both concepts - enable a better understanding of how David and Zeegert positioned themselves within center-periphery dynamics in their interaction in Extract 6. The three grammars of identity/alterity by Baumann and Gingrich (2004) are orientalization, segmentation, and encompassment. The orientalization grammar is referred to as reverse mirror-imaging. This grammar suggests negative mirroring (for example, what is good in us is lacking in them), but adds a subordinate reversal which results in potential self-critical relativism and a desire for the other (what is lacking in us is - still - present in them). The argument put forward by Zeegert and David in Extract 6 (Lines 13 to 17) shows that they, as the orientalization grammar suggests, desired the (stereotypical) Limburgers' ability to "take it easier" than Hollanders "who are chaotic and a bit manic." As a result of this, and in stark contrast with previous extracts, the center-periphery opposition of 'us outsiders' versus 'them Limburgers' was reversed, and both men (David agreed with what Zeegert claimed) seemed to adequate themselves with Limburgers instead of continuing to distinguish themselves from them. In other words, 'we, the outsiders' now seemed to align more with 'them, the Limburgers' through which 'them' became part of 'us.' Their identification as 'outsiders' who were out of place in Limburg was thus weakened. I will show below that the same situations or interactions can make use of different grammars at the same time.

\section{Center-periphery dynamics within Limburg}

The center-periphery power relation of Limburg versus Holland is not the only opposition that David and Zeegert related to when positioning themselves. In the following extract, David and Zeegert referred to oppositions and center-periphery dynamics within the province of Limburg itself.

\section{Extract 7}

1 Zeegert Al kom je uit $\uparrow$ Hoensbroek bijvoorbeeld, Even if you are from $\uparrow$ Hoensbroek for example,

2 Zeegert dan ze[y]en ze "die komt niet uit Roermond, they will say "he is not from Roermond,

3 Zeegert d-die laten we, die laten we $\uparrow$ niet (.) in de kern komen, samen zijn" w-we let him, we will $\uparrow$ not let him (.) get in the core, being together"

4 Lotte Ja

Yes

5 Zeegert Chauvinisme, hè Chauvinism, right

6 Lotte Ja, ja Yes, yes 


\begin{tabular}{|c|c|}
\hline 7 Zeegert & $\begin{array}{l}\text { Dat heeft daar ook een rol } \\
\text { That plays a role as well }\end{array}$ \\
\hline 8 David & Ja, daar zit ook vee/veul vriendjespolitiek in, hè (.1) \\
\hline 9 David & $\begin{array}{l}\text { Yes, there is also a lo/lot of nepotism involved, right, (.1) } \\
\uparrow w o a r e, \text { ja, het krii][x] je, hè? } \\
\text { 个isn't it, yes, that's what you get, right? }\end{array}$ \\
\hline
\end{tabular}

In order to illustrate that outsiders are not necessarily just people coming from outside the province, Zeegert stated that even people from Hoensbroek (a town in the south of Limburg, 48 kilometers from Roermond) would not be allowed to join in Roermond. According to Zeegert, these people would be excluded, just because they were not originally from Roermond. Why Hoensbroek was selected to exemplify this is not clear. Roermond versus Hoensbroek is not a common opposition that people relate to in daily discourse such as, for example, Roermond versus the capital of Maastricht. Nevertheless, with this argument Zeegert showed that he knew something about local oppositions and chauvinist sensibilities and that he embraced and oriented much more towards Roermond and its local relationships than he had claimed in the previous extracts. Similarly, David exposed his knowledge about Limburgian stereotypes in Line 8, in which he argued that the politics of nepotism is a cause of the provincial opposition between insiders and outsiders. By referring to this, David showed that he was familiar with the common stereotypes about the place he lived in (cf. Knotter 2009; Mathijsen 2011). In addition, his self-repair in Line 8 was remarkable. David started pronouncing the Dutch veel [ve:l] 'much,' but suddenly interrupted himself and corrected the word to the dialect veul [vœl]. This self-repair can serve as an example of the tactics of authentication and authority (Bucholtz and Hall 2004, 2005), because he used linguistic forms enregistered as dialect to validate his knowledge about nepotism in Limburg.

In this extract, David and Zeegert were not explicitly identifying with or against the opposition of Roermond versus Hoensbroek, although their reflections about other outsiders in Roermond seemed to follow up on their own out of placeness in the province. As such, they were adequating themselves with other outsiders, while, again, distinguishing themselves from those people who are originally from Roermond (cf. Bucholtz and Hall 2004, 2005).

This extract further contributes to notions of realness and artifice. In Extract 2 Zeegert connected realness with someone's place of birth by referring to "the real Limburgers, who were born here." In Extract 7, Lines 1 and 2, he replicated this idea by exemplifying that people from Hoensbroek could very well be regarded as outsiders within Roermond, since they were not born there. This replication is interesting for two reasons. First, these extracts give insight into how David and Zeegert thought: being born in a place renders authenticity, while having moved from somewhere else suggests inauthenticity (cf. Bucholtz and Hall 2004, 2005). This is in line with Geschiere's argument (2009) that being born on particular soil, autochthony, is often used to justify one's authentic belonging to a place.

Second, Zeegert's replication exemplifies the logic of fractal recursivity (Irvine and Gal 2000). Fractal recursivity involves the projection of an opposition, salient at some level of relationship, onto some other level (ibid: 38). Fractals are geometric figures that are self-similar, which means that they are built out of parts that are more or less similar to the figure itself as a whole. In this metaphor of fractal recursivity, Irvine and Gall point to the feature of fractals wherein patterns recur on increasingly smaller scales. Instead of making 
the postmodern claim here that David and Zeegert produced multiple and dynamic identifications of belonging, fractal recursivity suggests a pattern. Fractals, as used by anthropologist Marilyn Strathern, go against postmodern anything-goes 'flatness.' Strathern (2004: $\mathrm{xx}$ ) argues: "The relativizing effect of multiple perspectives will make everything seem partial; the recurrence of similar propositions and bits of information will make everything seem connected." In other words, to say that people affiliate or construct feelings of belonging to multiple places, groups, or 'cultures' would seem partial and flat, even unstructured. It would suggest that people identify with anything or nothing. This is similar to Bourdieu's (1990: 56) concept of habitus that suggests that there is always embodied history in a person's life that steers a person in a particular direction. It is permanence in change (ibid), in which there can be fractal recursivity that avoids portraying the construction of belonging as simply 'multiple' and, thereby, as flat.

Until now the interaction with David and Zeegert has related to different oppositions on different scales of center-periphery dynamics. On the one hand, the large opposition of Limburg versus the rest of the Netherlands, in which Limburg is usually seen as the odd one out, where people talk and behave differently, lay at the base of the claim "we are no Limburgers." On the other hand, in David's and Zeegert's claims of being outsiders, this large opposition recurs on a provincial scale where 'the Hollanders' are perceived as outsiders within Limburg. In Extract 7, then, the opposition of insiders versus outsiders recurred in relation to the regional scale by opposing people from Roermond, the insiders, and Hoensbroek, the outsiders. According to Zeegert, feelings of being out of place could even occur when a person born in Limburg moved within the province. This shows that one need not be a Hollander to be perceived as an outsider in Limburg. The opposition of belonging versus unbelonging, insider or outsider, thus recurs on another level; from Limburg versus Hollander to Roermond versus Hoensbroek (or the rest of Limburg). The next section focuses on how oppositions within the city of Roermond were constructed in the interaction I had with David and Zeegert.

\section{Oppositions within Roermond: belonging through unbelonging}

The upcoming two extracts, Extracts 8 and 9 below, illustrate how the opposition of insiders versus outsiders recurs on the more local level (cf. Irvine and Gal 2000) of Roermond. In this way, oppositions at the national level 'fractalize all the way down' to more local scales (cf. Eckert 2011).

David and Zeegert put themselves in the position of outsiders within Limburg as well as in Roermond. My situated interaction with David and Zeegert illustrated the workings of politics of (un)belonging in everyday situations, since it showed how, in meeting others, "people may decide whether they stand inside or outside the imaginary boundary line of the nation and/or other communities of belonging" (Yuval-Davis 2006: 204). It is thus about whether I was perceived by David and Zeegert as part of 'us' or 'them.'

Crucially, in order to interpret the social meanings of the extracts below, the construction of a particular form of belonging has to be proposed, which I call belonging through unbelonging. I claim that it is through David's and Zeegert's shared feelings of unbelonging within Limburg and Roermond that they felt a sense of belonging together. In Extract 8 they first tried to bond with me by assuming that I shared this feeling of being out of place within Limburg. Yet after establishing that I was an insider, a Roermondenaar who did not 
recognize how "real Limburgers" behave towards outsiders because I was born here, they clearly drew a line between themselves, the outsiders, and me, the insider.

As such, Extracts 8 and 9 below illustrate that the ethnographer on site serves as a tool to generate insights into the relations between language practices, place-making processes, and politics of (un)belonging. In a reflexive ethnographic place-making perspective I explicitly reflect upon my own emplacement in research locations and the ways that my ethnographic experiences are embodied (cf. Pink 2008, 2009; Davies 2008; Rosaldo 1993, see Chapter 2). In Limburg and the Netherlands, my appearance is generally interpreted by others as being 'different.' This adds the dimension of appearance to the language-place-body connection (cf. Quist 2010): to be perceived as coming from a particular place, one's appearance needs to be in line.

The following extracts are examples of this. David and Zeegert did not seem to think that I was from Roermond at first, which is why I started by convincing them of this in Extract 8, Line 1 below:

\section{Extract 8}

1 Lotte Ja, ik kom zelf ook uit Roermond Yes, I come from Roermond myself

2 David Oh, dan zal u dat wel weten, hè? Oh, then you know, right?

3 Lotte Ja, ik merk het niet zo heel er[x] Yes, I do not recognize it very much

4 David $\quad=$ Nee, dat merk je ook niet $=$ No, you don't recognize that

5 Zeegert =omdat je zelf Roermondenaar bent, = maar als je buitenstaander bent, $=$ that is because you are a Roermondenaar yourself, $=$ but if you are an outsider,

6 Lotte =Ja, maar ik heb hier ook niet meer zo heel veel vrienden of, eh, $=$ Yes, but it is not like I still have many friends here or, uh,

7 David Ik denk als je hier bij een vereni[X]ing wilt komme (.) of biej een sangkeur, koor I think that here if you want to join a community (.) or a choir, choir

8 David of een carnaval, daar komme wij [x]een, $\uparrow$ nemes tusse jong or a carnival, we can't, $\uparrow$ nobody steps in, boy

9 Zeegert $=\mathrm{Nee}=$, daar kom je niet $\uparrow$ bij. $=\mathrm{No}=$, you can't $\uparrow$ join.

10 David Daar kom je niet tusse. You can't step in.

11 Zeegert Dan kom je/ dan moet je xxx dan moet je hier $\uparrow[y]$ ]eboren zijn Then you come/ you have to xxx you have to be $\uparrow$ born here

12 David =want die zèly]e je zo: wat mot dae?= =because they will say: what's up with him?=

After having said that I was from Roermond as well, David expected that I would be familiar with being the outsider (Line 2), probably because he assumed I was not born in Roermond due to my appearance (see also Extract 9, where this became even more explicit). In a way, in Line 2, he tried to adequate (cf. Bucholtz and Hall 2004, 2005) himself with me as being both outsiders. After claiming that I did not recognize the feeling of being an outsider (Line 3), both men immediately acknowledged that I was an insider and 
unable to recognize how "real Limburgers" behave towards outsiders, given that I was Roermondenaar myself (Line 4 and 5). In doing so, they drew a boundary to distinguish between themselves, the outsiders who did not belong, and me, a Roermondenaar who did (cf. Bucholtz and Hall 2004, 2005).

David went on to argue in Line 7 that for outsiders, like them, it was hard to join a community, choir or carnival association. His own experience in the carnival association of Thorn both exemplified and challenged this; on the one hand, he was able to join the association, yet on the other hand, his announcement as prince carnival was not accepted at once by other members of the association. Zeegert agreed with David about its being hard to join particular groups and communities and said he believed that one had to be born in Roermond in order to fit in (Line 9 and 11), thereby again reproducing the idea that 'to be born from soil' authenticates one's belonging in that place (cf. Bucholtz and Hall 2004, 2005; Geschiere 2009). David stated that if one were to try to join, 'they' (people in a particular group or community) would ask what that person wanted (Line 12). This question "wat mot dae?" ("what's up with him?") seemed to be as hostile as the member who challenged David's plan to become prince carnival in the village of Thorn. It seemed that, for David, this questioning and challenging strengthened his feeling of unbelonging. It is through such questions in interactions that politics of (un)belonging are shaped among people, since they emphasize again and again that someone is regarded as 'the other' who does not fit in or is out of place.

At that moment of the conversation, our interaction fell silent for a while, and Zeegert decided to go his way and said goodbye. I sat down on the bench next to David, and we were both observing the plaza and the passersby, when he asked me:

\section{Extract 9}

1 David Maar u bent ei[y]enlijk ook [X]een Roermondenaar? But are you actually no Roermondenaar either?

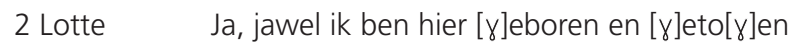
Yes, yes, I was born and raised here

3 David = Omdat $\mathrm{u}$ zo'n zwarte haren hebt en $\uparrow$ hele $\uparrow$ zwarte $\uparrow o[\mathrm{X}]$ ]en $=$ Because you have such black hair and $\uparrow$ very $\uparrow$ black $\uparrow$ eyes

4 Lotte Ja, dat is waar, ja, ik ben half, eh, Roermonds, [smiling voice] Yes, that is true, yes, I am half, uh, Roermonds,

5 Lotte ofja eigenlijk half Nederlands, or actually half Dutch,

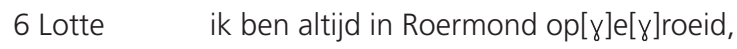
I was always brought up in Roermond,

7 Lotte en dialect ook wel leren spreken ei[y]enlijk, and learned to speak dialect actually,

8 David = Ja jao $=$ Yes yes

Although I had explained in Extract 8 that I was from Roermond, David again questioned in Extract 9, Line 1 whether I was actually no Roermondenaar. By using the word ook (literally 'too,' in the translation 'either'), David tried to adequate himself with me by assuming we had something in common, namely, that both of us were out of place and outsiders within Roermond. When I told him that I was born and raised in Roermond 
(Line 2), he related to notions about what constitutes a real Roermondenaar by referring to my appearance with emphasis (Line 3). What is remarkable is how David pronounced the words "eigenlijk ook geen Roermondenaar" ("actually no Roermondenaar either") in Line 1 and "zwarte ogen" ("black eyes") in Line 3. For the words eigenlijk geen and ogen, David used the uvular voiceless fricative that is usually interpreted as an index of outsiders in Limburg. It could thus be argued that by using this fricative, David tried to adequate himself with me. Similar to Extract 8, David aimed to establish a form of belonging through unbelonging with me. This illustrates the encompassment grammar of Baumann and Gingrich, which refers to the belief that others, who are subordinated to a hierarchical norm, are simply exaggerating their difference while, deep down, being an encompassed part of 'us' (Baumann and Gingrich 2004: 27). By explicitly questioning, again, whether I was actually a Roermondenaar, David tried to figure out if I was, deep down, not really 'part of us,' the outsiders.

Yet, at the same time, by making explicit reference to my looks in Line 2, David took up authority to illegitimize my belonging to Roermond and to challenge whether I was authentically from Roermond (cf. Bucholtz and Hall 2004, 2005). With this, he put himself in the position of an insider who knew what looks are generally perceived as belonging to Roermond. Clearly, my black eyes and hair were too extraordinary to be perceived as such. As a result, David was reproducing a place-body connection (cf. Quist 2010) which claimed that my looks could not be from 'here,' Roermond.

\section{'I am half, uh, Roermonds'}

While first laughing about his remark, I said I was half Roermonds (Extract 9, Line 4). Since this did not make any sense, I corrected myself and claimed in Line 5 that I meant half Dutch. This revealed that I was a bit astonished by David's remark, even though I am often confronted with these questions. I continued to explain to David that I was brought up in Roermond (Line 6) and that I had actually learned to speak dialect (Line 7). Hence, Lines 4 to 7 demonstrate that I was trying to defend and authenticate my own belonging and to weaken David's attempts to illegitimate my belonging by strengthening a language-placebody connection (cf. Quist 2010) and by making explicit use of my embodied otherness (cf. Bucholtz and Hall 2016; Pink 2009). This clearly illustrates that, "the cultural context of 'where you are at' always informs and articulates the meaning of 'where you are from'" (Ang 1994: 35). While interacting with David, I foregrounded and authenticated that I was from Roermond. ${ }^{46}$ David's response to my remark about dialect with the words ja jao in Line 8, the latter 'yes' being pronounced in dialect, can be explained in two ways. First, David acknowledged that I knew the dialect by responding with confirmative dialect jao. Second, David showed that he also belonged to Roermond and used an index to emphasize this. As a result, this extract exemplifies the tactic of denaturalization, since, in the end, David seemed to adequate himself with me as both belonging to a certain degree to Roermond, despite my denaturalized looks for a Roermondenaar.

Extracts 8 and 9 demonstrate how the recurring opposition of insiders and outsiders was reproduced on the level of Roermond. First, after David and Zeegert failed to bond

\footnotetext{
${ }^{46}$ Contrastingly, in Chapter 8, I will foreground the fact that I am 'half foreigner' when interacting with the butcher at Dost Market.
} 
with me through our shared feelings of unbelonging, they drew a boundary between themselves as outsiders and me as insider within Roermond. Then, in my interaction with David alone, David again tried to construct belonging through unbelonging with me, yet, at the same time, took up the position of being insider in the city by pointing out that dark hair and eyes were not accepted looks for an authentic Roermondenaar. Furthermore, these extracts emphasize the strength of ethnography for this kind of research, since the researcher's presence enabled collecting - or rather provoking - data on oppositions of 'us' and 'them' that would otherwise have been hidden. In addition to this, these extracts clearly illustrate the idea that ethnographic fieldwork is always sensory and embodied (cf. Pink 2009): it was only because of my appearance that I learned how David interpreted my looks and what the implications were of that in relation to belonging.

\section{Conclusion}

This chapter examined a specific case of how people give meaning to places and relate to others during interactions in these places. Through the analysis of my conversation with David and Zeegert, I aimed to examine how both belonging as well as unbelonging to places can be expressed through the use of linguistic forms. I demonstrated two aspects. First, by paying close attention to the men's use of linguistic forms, such as the velar and uvular fricative and dialect forms, it became clear how language practices may provide indexical meaning: using a uvular fricative might index 'an outsider' within Limburg while the use of velar voiced and voiceless fricative and dialect would suggest otherwise. As part of this, the interaction with David and Zeegert disregards the tradition of mapping linguistic forms onto maps, thereby fixing language, place, and body. The data rather supported the idea that people use language as a resource to draw from, while the fixed connection between language, place, and body is at the same time a powerful ideological belief to give meaning to the world. Moreover, the data showed how people might put indexical meanings to use to align with or distance themselves from others in a particular place.

Second, the case study revealed how people appropriate the places around them and engage in processes of place-making by making use of language and cultural practices. Where David and Zeegert perhaps felt in place within Roermond, they felt out of place among 'its' people. The two men thus related to different 'modes of belonging' (Sicakkan and Lithman 2005) or 'differential belonging' (Rowe 2005), demonstrating a variety of attachments to different places, groups, and cultures (cf. Antonsich 2010). David's and Zeegert's practices thereby disclosed that their ambivalent being-in-the-world (cf. Csordas 1994) put them both in place as well as out of place, which provided insight into the production of the third important aspect, namely, the politics of (un)belonging. In the interaction, David and Zeegert claimed and (il)legitimized multiple and ambiguous feelings of belonging and unbelonging at recurring scales, thereby also relating to me and constructing a form of belonging through unbelonging as outsiders. As such, the case of David and Zeegert stresses that people continuously redefine their feelings of belonging and unbelonging within and to the places in which they live and that belongingness is not a final state-of-being that can be achieved (cf. Youkhana 2015; Yuval-Davis et al. 2006). The case study serves as a concrete example of the intricate links between language practices, place-making and politics of (un)belonging in everyday interactions and locations.

This chapter has shown how people use tactics of intersubjectivity in interactions to 
shape politics of belonging and unbelonging and to value themselves and others in terms of realness and artifice. Moreover, the extracts exemplified the working of fractal recursivity and the ways that different oppositions of center and periphery became salient in the production of belonging and unbelonging. In the extracts examined, David and Zeegert constructed politics of (un)belonging that included multi-layered and rapidly shifting identifications and oppositions within the field of Limburg. Their initial identification as "outsiders" seemed to be ambiguous after looking at the other extracts and even reversed in relation to "the chaotic West" and 'the dark-haired and dark-eyed researcher.' Using the grammars of Baumann and Gingrich allowed me to highlight these multidimensional ambiguities and contradictions that David and Zeegert displayed in our interaction, which showed that the same situations or interactions can make use of different grammars at the same time in which they appear as competing or rival versions of constructing sameness and otherness. Moreover, David's and Zeegert's shared feelings of unbelonging to Limburg seemed to provide at the same time a feeling of belonging between them; a form of belonging through unbelonging. Hence, politics of (un)belonging are never supported by fixed and stable oppositions; they are, rather, highly ambiguous, contextual, and multilayered, while also reproducing recurrent oppositions.

Part II presents a different perspective to Part I's De Katers research case and shows that linguistic forms that are associated with dialects in Limburg are not only used by the so-called 'local-born' Limburgers David and Zeegert claimed not to be. Similar to the carnival monarch's using Dutch on stage and the national figure of Sinterklaas's using dialect, David and Zeegert were languaging (Jørgensen et al. 2011; Møller \& Jørgensen 2009) and using linguistic forms that they had acquired over the course of their lives, including forms producing localness in Limburg. At the same time, however, they explicitly claimed to be "no Limburgers." I have argued that I regard this as a form of belonging through unbelonging in which shared feelings of unbelonging within Limburg and Roermond evoked a sense of belonging together. Similar to Part I, Part II showed that there was a discrepancy between what people say and believe they do and what they actually say and do (cf. Labov 1966) when examining situated interactions (Gumperz 1997). In Part III, which follows, I take the reader to the neighborhood of De Donderberg where I conducted fieldwork in the small-scale supermarket of Dost Market. 


\section{Part III}

Grocery practices at the Dost Market supermarket in Roermond's De Donderberg neighborhood 


\title{
Chapter 7
}

\section{Entering the field of grocery practices at De Donderberg's Dost Market}

\section{Introduction}

One day in June 2012 the participants of the cooking club Borderless Delight, in the neighborhood of De Donderberg in Roermond, could not stop talking about a new supermarket in the neighborhood's shopping mall, which they referred to as 'the Turkish shop.' It was, according to them, a tremendous addition to the shopping mall and the neighborhood as a whole. Intrigued, I paid a visit to Dost Market, which is a family-run supermarket owned by two brothers, Ihsan and Seyithan (hereafter Seyit, his nickname), and their cousin. During this first visit, I overheard multilingual interactions between staff and customers, in which I came across linguistic forms such as mazyan (Moroccan Arabic) for 'nice' or 'beautiful,' nana (Moroccan Arabic) or nane (Turkish) for 'mint,' kosbor (Moroccan Arabic) for 'coriander,' and kapusta (Polish) for 'cabbage.' 47 These observations established Dost Market as a significant fieldwork site ${ }^{48}$.

\begin{abstract}
"Mazyan, isn't it? They are really fresh!" The butcher recommends the 'nice' Moroccan pancakes to a customer who is looking at the delicacies that lie next to the butchery. "Is there any nana left?" a customer asks to request 'mint.' The butcher instructs his helper in what I presume is Turkish to get it. "While you are going, can I have kosbor?" another customer quickly jumps in, asking for 'coriander.' The helper goes to the storage in the back of the supermarket to get nana and kosbor. He comes back with the fresh bundles of herbs and hands them over to the customers. While weighing a bag of ground beef, the butcher greets an entering customer with a loud "kapusta!", a word, I learn later, that literally translates into 'cabbage.'
\end{abstract}

(Field notes, June 27, 2012)

I decided to conduct research here to examine how staff and customers, while working or doing grocery shopping, give meaning to the supermarket as a place where people and linguistic forms, generally associated with different parts of the world, come together. In my fieldwork I was interested in how staff and customers engage in interactions and the particular language practices they mobilize for this.

From early on anthropologists have been interested in markets to examine how people socially and culturally engage in economic deals and exchanges (Black 2012; Geertz 1978; Plattner 1985). I perceive supermarkets not only as sites of economic deals and

\footnotetext{
${ }^{47}$ I deliberately write Moroccan Arabic, since the nouns that were used at Dost Market would generally be associated with the Moroccan variety of Arabic. Yet these nouns could also be understood in other Arabicspeaking countries. As for the staff members and customers at Dost Market, the label Moroccan Arabic serves as an umbrella term for all those speaking and understanding different (regional) varieties of Arabic. ${ }^{48}$ The following description is compiled from field notes taken in Dutch during and after this first visit.
} 
exchanges but also as social places where people interact. Increasingly, so-called 'ethnic shops' have also been a major topic of research in a variety of disciplines. Studies by Collins et al. (1995), Jamal (2003) and Van der Schans et al. (2009) have focused on the interplay between retailing, ethnic identity, consumption, and ethnic entrepreneurship, while others have specifically examined how ethnic shops become meaningful spaces for remembrance and the construction of belonging to diaspora communities (Everts 2010; Mankekar 2002). Van der Schans et al. (2009: 20) observed that so-called allochtonen (their words to refer to persons with a 'non-native' background) prefer 'Turkish shops' over chain supermarkets, where products are hard to recognize due to the packaging and language barriers. Apart from this brief observation, the linguistic dimensions of groceries, markets, and supermarkets have been largely overlooked, and explicit studies of language practices in these places are lacking. Exceptions include Franziskus and Gilles (2012) and Franziskus et al. (2013), Pennycook and Otsuji (2014b), and Karrebæk (2015), who closely examine how diverse and hybrid linguistic repertoires are put into use in interactions in daily situations in supermarkets, market places and green grocers, respectively. These studies provide useful insights into how language can be commodified, which is to treat language as a means or good by which to earn profit, for instance, tourism or advertising (see Heller 2010; Heller et al. 2014). Moreover, rather than focusing on central and urbanized areas such as the city of Luxembourg in Luxembourg (Franziskus and Gilles 2012; Franziskus et al. 2013), Sydney in Australia (Pennycook and Otsuji 2014b), Copenhagen in Denmark (Karrebæk 2015), Berlin in Germany (Wiese 2012) and Amsterdam (Appel 1999), Rotterdam (Cornips and De Rooij 2013) and Utrecht (Bennis et al. 2002) in the Netherlands, this research case of Dost Market in Roermond emphasizes, just as the other two research cases did, that people living in peripheral areas also engage in languaging practices (cf. De Lima 2012; Jørgensen et al. 2011; Wang et al. 2013).

Dost Market falls under the tertiary sector of the economy also referred to as the service sector, where businesses try to profit by selling or providing particular services or products. This is an important context to take into account when examining profit-making businesses such as Dost Market, since work practices primarily aim at selling as many products as possible in order to maximize profit. To achieve this, the staff of Dost Market made sure that the shop looked good to customers. The store could best be described as an economic location where money is made. On the one hand, it is a location where people come to in order to buy goods, while, on the other hand, it is a workplace where employees work together in order to make money. Duchêne and Heller (2012: 8-10) argue that within this late capitalist context - which includes the expansion of markets, tertiarization, flexibilization, and the making of distinction - the role of language becomes increasingly important in providing symbolic added value to products and services and into sustaining transnational networks. According to them, the intertwined tropes of 'pride' and 'profit' (ibid: 3) influence people's motivations to learn and use particular linguistic forms. Moreover, by responding to and making use of people's (assumed) linguistic and cultural affiliations and feelings of belonging, language practices can transform pride into profit (cf. Del Percio and Duchêne 2012: 68). I will show, in Chapter 8 particularly, that both pride and profit are indeed important motivations for the people at Dost Market to engage in particular language practices.

During my nine months of fieldwork at Dost Market, my observations focused on addressing two specific questions: Which language and culture practices are perceived as being in and out of place, and why and how does this relate to perceptions of who 
belongs and who does not? I observed explorations and improvisations that produced new linguistic routines: the use of the Polish kapusta to greet customers with a particular assumed language background and the use of Moroccan Arabic, mazyan, nana, and kosbor being other examples of this. My fieldwork observations, experiences, and conversations will give insight into the ways that people, while engaging in mundane practices such as working and shopping in a supermarket, give meaning to the places they inhabit and the people they encounter in these places.

In this chapter, Dost Market will be introduced to help the reader to visualize the location where I conducted fieldwork. In the next section, I reflect on how I started my ethnographic fieldwork at Dost Market. ${ }^{49}$ In Section 7.2, I elaborate on Dost Market's location within Roermond. In Section 7.3 I provide my impressions of the daily staff and their practices. Moreover, I address the following questions: How do people engage with each other in the supermarket and what kinds of interactions take place? How does the store look and what products can customers buy? The last section details the ethical considerations I had to take into account and my own positioning within the supermarket.

\subsection{Doing ethnographic fieldwork at Dost Market}

\section{Getting fieldwork started}

After my first visit to Dost Market in June 2012, I gathered up my courage and asked coowner Ihsan whether I could occasionally visit the shop to do research. At first he hesitated to take me on board, mainly because Dost Market was still rather new and thus in the process of building customer relations. Ihsan advised me to discuss it with his brother, Seyit. Upon meeting Seyit, I quickly gained his permission, as he was very enthusiastic about language as a research topic.

My first fieldwork visits consisted of hanging around in the shop, only to find out that it was very awkward to just stand and take notes in a place where others came to work or shop for groceries. Customers asked me numerous times whether I was standing in line to order meat at the butchery or to check out groceries at the cash desk. This made me realize that my behavior was confusing both staff and customers and that I was interrupting normal routines at Dost Market. I aimed to become more of an observantparticipant rather than a participant-observant, to allow for a more backstage perspective (cf. Moeran 2007). I gathered it was best to do something in order to fit in and asked Seyit if I could - voluntarily of course - carry out some tasks, such as sweeping floors, cleaning, or stocking of shelves. He at first hesitated and pointed out that I really had to be serious about it and put my heart into the work. Fortunately, I had worked in supermarkets as a student, so I roughly knew how to deal with things, such as stocking and aligning products on shelves. This had implications for my own emplacement (cf. Pink 2009) and my inclusion and exclusion as an ethnographer at the supermarket, since I had to balance between

\footnotetext{
${ }^{49}$ In all chapters, I refer to the most significant staff members of Dost Market with their real names. Unless indicated otherwise, most staff members gave their consent to use their real names and to be audio-recorded. I did not receive explicit consent from customers to use their real names (in case I knew them), therefore I refer to customers with 'man' or 'woman' for the sake of privacy.
} 
different roles and expectations, on which I will elaborate in Section 7.3. Slowly but surely I became more like an employee, doing more than just cleaning tasks, and I started working at the supermarket at least two mornings or afternoons a week. I thus found myself starting my ethnographic fieldwork by working as a volunteer in Dost Market, while taking notes and making sound recordings. Not long after my first visit, I fetched mint and coriander from the storage myself, and I was no longer surprised that the Polish kapusta was used as a greeting in this supermarket rather than referring to 'cabbage.'

\subsection{The location of Dost Market}

Dost Market is located within Roermond's southeastern Donderberg neighborhood or 'De Donderberg,' as inhabitants of Roermond refer to it. ${ }^{50}$ The neighborhood was built on the spot where there used to be a hill called Donderberg, literally 'Thunder Mountain. ${ }^{51}$ The hill was removed to enable the building of a new neighborhood in the 1960s and 1970s to provide space for Roermond's increasing population (Ministry of Interior and Kingdom Relations 2011: 23). De Donderberg consists of four quarters: Componistenbuurt, Vliegeniersbuurt, Kastelenbuurt, and Sterrenberg. Componistenbuurt is the oldest quarter, built in 1967 (Moors 1996: 21).52 It is here where most social housing is to be found, either in the form of large apartment complexes or small single-family houses. In 1972, Sterrenberg, formerly known as De Planetenbuurt, was built. In this quarter only a few privately owned houses are to be found, next to small social housing apartment complexes and small single-family houses similar to those found in Componistenbuurt. Kastelenbuurt was built in 1975 and is a combination of large single-family houses (owned by social housing companies) and privately owned houses. Besides these quarters there is the newer quarter of Vliegeniersbuurt, where one can find two large social housing apartment complexes and privately owned houses. The big road of Donderbergweg divides the four quarters; on one side of the road Vliegeniersbuurt and Kastelenbuurt are located, while on the other side one finds Componistenbuurt and Sterrenberg, as depicted in Figure 7.1.

Figure 7.1: Google Maps screenshot of Roermond's De Donderberg neighborhood with the quarters of Vliegeniersbuurt (bottom left), Componistenbuurt (bottom right), Kastelenbuurt (upper left), and Sterrenberg (upper right) highlighted. The vertical line in the middle, separating Kastelenbuurt and Vliegeniersbuurt on the left from Sterrenberg and Componistenbuurt on the right, depicts the neighborhood's main road, Donderbergweg (Image by Google Maps, courtesy of Google Maps).

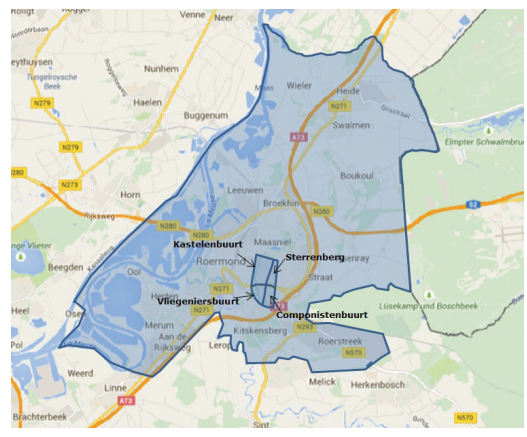

\footnotetext{
${ }^{50}$ Since inhabitants of the neighborhood usually refer to it as De Donderberg, I will stick to this nomenclature throughout this dissertation.

${ }^{51}$ The existence of this hill can oftentimes be traced back in people's references to the neighborhood: when asking someone where he or she lives, people usually say "on De Donderberg," suggesting that they actually live 'on' a mountain.

${ }^{52}$ All historical information about Donderberg is taken from Moors (1996: 19-28).
} 
While the Municipality of Roermond provided population numbers in 2016 (Municipality of Roermond 2010: 3$)^{53}$, civil servant Jan Koerts of the Municipality of Roermond helped to break down the numbers for the four quarters of Componistenbuurt, Sterrenberg, Kastelenbuurt, and Vliegeniersbuurt from these numbers, revealing that these quarters were inhabited by 7,150 people as of January 1, 2016. ${ }^{54}$ Since Dutch law nowadays prohibits registering a person's nationality, other than the Dutch nationality, figures on the backgrounds of a neighborhood's population are not very reliable. For instance, for dual nationals, only the Dutch nationality of a person is registered. Yet another possibility is that dual nationals, other than Dutch, such as German-Turkish, are counted as one German citizen and one Turkish citizen, thereby doubling the numbers (personal communication with Jan Koerts, April 17, 2015). As with all population numbers in this dissertation, Figure 7.2 below only gives a very rough idea about the composition of De Donderberg compared to Roermond and does not give insights into how people themselves affiliate or identify.

\begin{tabular}{l|cc}
\hline & De Donderberg & Roermond \\
\hline Total inhabitants & 7,150 & 57,010 \\
Autochtoon & 4,620 & 40,926 \\
Westerse allochtoon & $\underline{\mathbf{6 4 . 6 \%}}$ & $\underline{\mathbf{7 1 . 8} \%}$ \\
Niet-westerse allochtoon & $\mathbf{7 9 1}$ & 8,353 \\
& $\underline{\mathbf{1 1 \%}}$ & $\underline{\mathbf{1 4 . 7} \%}$ \\
\hline
\end{tabular}

Figure 7.2: Composition of inhabitants (autochtoon, Westerse allochtoon, and niet-westerse allochtoon, labels used by CBS Statline) by number and percentage for De Donderberg and Roermond (CBS Statline 2016; Municipality of Roermond 2016: 20).

Out of the 7,150 inhabitants of the four quarters of De Donderberg, $64.6 \%$ of the inhabitants are labelled autochtoon according to CBS. 11\% count as Western allochtoon, people with origins in other Western countries, including East European countries such as Poland, Bulgaria, Romania, and the former Yugoslavia. $24.4 \%$ of those residing in the four quarters of De Donderberg are labeled as non-western allochtoon. ${ }^{55}$ Of this, 588 inhabitants are of Turkish descent and 326 inhabitants are of Moroccan descent.

\footnotetext{
53 I deliberately use numbers from 2016, as provided by the Municipality of Roermond, since the numbers in Figure 1.5 of Chapter 1 and Figure 4.1 of Chapter 4 are also based on 2016.

${ }^{54}$ These numbers are not based on the official document as published by the Municipality of Roermond in January 2016 but are based on Excel documents provided by Jan Koerts in which the numbers for the four De Donderberg quarters were separated out. I thank Jan Koerts of the Municipality of Roermond for these numbers. ${ }^{55}$ Allochtoon is a label used to refer to those people who have at least one parent born outside of the Netherlands (see Section 1.1 of Chapter 1). In practice, allochtoon is mostly used to refer to people who have a non-Western background. The opposite, autochtoon, refers to someone's nativeness in a country. Although the labels are debated upon in politics, many people still use the labels.
} 
De Donderberg neighborhood has been and is experienced by residents as well as others, albeit decreasingly, as a neighborhood with a bad image and quality of life (Neighborhood development plan Donderberg 2012: 5). The diffusion of negative images about De Donderberg encouraged publicist Petra Stienen (2015) to return to see what had happened to her old neighborhood. Her book narrates stories about how residents live together and try to make their home within De Donderberg (ibid: 12). Instead of focusing on quality of life, security, and bad images of the neighborhood, Stienen shows that not all is lost and that residents are coping with problems and making their living in their own ways (ibid: 221): for example, by celebrating carnival in the neighborhood, setting up a soccer team for the neighborhood's youth, and adolescents succeeding in careers and studies. Similarly, I focus on how people deal with each other within the confines of Dost Market by looking at linguistic and cultural practices, instead of confirming De Donderberg's negative images and problems. Nevertheless, I am of the opinion that this context is needed in order to understand in what kind of neighborhood Dost Market is situated.

High crime rates and occurrences of nuisances, break-ins, and robberies in 2006 and 2007 have, in retrospect, been recognized as the main causes for De Donderberg's bad reputation (House of Representatives of the Netherlands 2010). These delicts affected residents' subjective feelings of security in negative ways. Even before the rise in delicts in De Donderberg in 2007, residents had already indicated that they did not always feel safe in their neighborhood. In 2002 and 2005, respectively 38.8\% and 32\% of the residents claimed to feel unsafe in De Donderberg (Van der Torre et al. 2007: 32). The percentage declined to 23\% in 2008 but rose again to 30\% in 2010 (Neighborhood development plan Donderberg 2012: 28). Coverage of this situation in the neighborhood in both national and regional media fostered a bad image of De Donderberg, both within and outside Roermond (Fassotte 2009; Van Beek 2010). Still, despite the improving situation, people in Roermond perceive the neighborhood 'as an outskirt of the city.' In another part of my conversation with Zeegert (which I did not include in Chapter 6), he pointed out that the lower crime rate is the most important advantage of living in the city center, while the outskirts suffer from more criminality. When I asked him where these outskirts are, he replied without any hesitation, "Donderberg" (Recordings, July 3, 2012). ${ }^{56}$ During the monthly women's breakfast club organized by the mosque close to De Donderberg, the group of women I sat with also regarded it as a disadvantaged area of Roermond. While enjoying our plates full of feta, Turkish flatbread, olives, and salad, we introduced ourselves to each other. During this, the bad image of De Donderberg was brought up when Ria told us that she lived in Kastelenbuurt. Marleen remarked to me:

\section{Extract 1}

Marleen: Daar kom jij ook vandaan toch?

That is where you live as well, right?

Ria: Oh, where?

Oh, waar dan?

Lotte: $\quad$ Kasteel Aerwinckelstraat.

Ria: $\quad$ Ah, dan wonen wij aan de goede kant van de Donderberg.

Ah, so we live on the good side of De Donderberg then.

\footnotetext{
${ }^{56}$ Original transcript: Zeegert: "Ik zal zeggen, het voordeel van het centrum is weinig criminaliteit. Ik zeg niet dat het goed is, maar weinig. Want als je in de buitenwijken woont, en dat is overal, dan heb je meer criminaliteit." Lotte: "En wat zijn hier de slechtere wijken in uw ogen?" Zeegert: "Donderberg."
} 
Lotte: Oja?

Is that right?

Ria: Ja, de rest, Pluto, Mozart enzo, dat is niks.

Yes, the rest, like Pluto[street], Mozart[street], and so on, that's no good.

Marleen: Daar ben ik geboren!

I was born there!

Ria: Jaja, ik ook. Wij woonden naast elkaar en toen was dat nog prima, maar nu!

Yes, yes, I was born there too! We even lived next to each other. Back in the day, it was very nice to live there, but now!

(Recordings, December 6, 2012).

In order to improve De Donderberg's image, the city council and national government decided in 2012 to invest more money into De Donderberg - the renovation of the shopping mall being one of the main investments (Driessen 2015). Still, many inhabitants believe that the neighborhood has been neglected by the city council. This was pointed out by a brother of the supermarket's owners, who regularly helped in the store, when I met him for the first time and told him that Dost Market was a great spot for my research:

\section{Extract 2}

Brother: $\quad$ Yes, absolutely. In any case, the whole of De Donderberg is. In the city center you find a different kind of people, they also act differently from us. This has worsened the last couple of years. The rich are getting richer and we remain the same. All innovations and investments happen in the Design Outlet Center, but not here, with us. Industry has completely disappeared, but then they tell us: we create jobs! But what kind of jobs? A job where you only earn 1000 euros a month, that is a pittance job. Everything is in the hands of Van Rey and Van Pol! We don't profit. Yes, now they are going to renovate the shopping mall, because they have to; things are falling apart here!

(Field notes, August 3, 2012) ${ }^{57}$

In his heated monologue, the brother constructed an opposition between De Donderberg and the city center and observed that many investments went to the city center, especially to the touristic Designer Outlet Center (see Chapter 1). The shopping mall of De Donderberg, not being a tourist attraction, only got renovated when it was really required. The brother's comment is a clear example of how people in a particular place shape ideas about dominant power relations of who is in charge or not (cf. Giddens 1984; Hannerz 1989; Kearney 1995). Moreover, the brother imagined De Donderberg neighborhood as a peripheral area that was also marginal in the sense that it had to cope with disadvantage and inequality, in comparison to the perceived center (Hall 2015; Wacquant 2008), in this case the city center of Roermond.

\footnotetext{
57 In his account, the brother referred to the infamous politician of Roermond, Jos van Rey, who worked closely together with building contractor and friend Piet van Pol. This cooperation allegedly has been too close, since Van Rey was accused of a conflict of interest and corruption in October 2012 by the public prosecutor. However, as becomes clear from the abovementioned account, many inhabitants of Roermond already knew about the close cooperation between the two men.
} 
Figure 7.3: Google Maps screenshot of the city of Roermond with De Donderberg neighborhood and the location of the shopping mall highlighted (Image by Google Maps, courtesy of Google Maps).

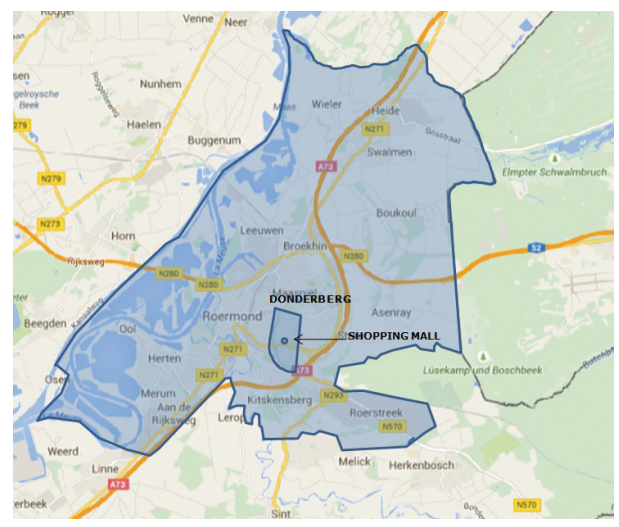

Within the neighborhood of De Donderberg there are many public services: a shopping mall, two primary schools, a school for vocational studies, a church, and, close to the border between De Donderberg and Maasniel, a mosque. The supermarket where I conducted fieldwork is located in the shopping mall. In the 1970s the shopping mall was built to accommodate the growing number of residents in the new neighborhood. This mall, officially called Winkelcentrum Donderberg (Donderberg Shopping Mall), can be found within the heart of the neighborhood, next to the neighborhood's main road, Donderbergweg, see Figure 7.3.

The shopping mall might be seen as a bridge between the four quarters of De Donderberg, itself located on the boundary between the quarters. During my fieldwork period, the renovation of the shopping mall started, a long-awaited development, as pointed out in the brother's comment above, given that the shopping mall had been unchanged since the 1970s. While the shopping mall remained open for customers, new parts were added and old parts were either torn down or modernized. On October 23, 2014, the renovated shopping mall was officially 'opened' with festivities and special offers. Since my fieldwork in the supermarket took place before the completion of the renovation, I describe the shopping mall as it was before (and during) the renovations.

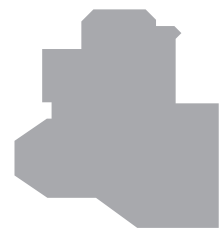

PASTOORDEWITPAD

Figure 7.4: Floor plan of Donderberg shopping mall before the renovation, number 5 being Dost Market, where my fieldwork took place (Image courtesy of Traanberg Partners Architectuur en Bouwmanagement).

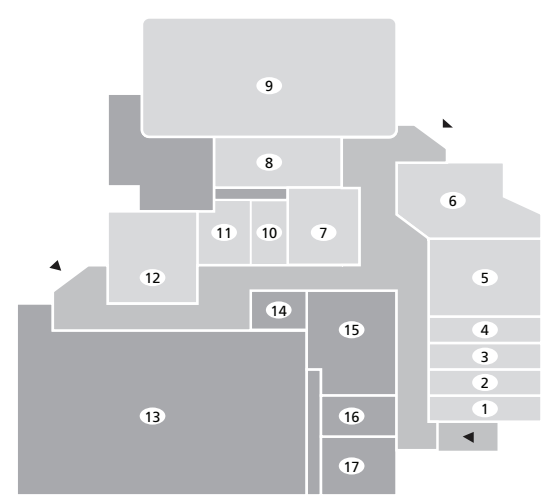

KASTEELHORNSTRAAT 
The shopping mall had (and still has) three entrances, two that could be entered from Kastelenbuurt quarter and one from Sterrenberg quarter. Figure 7.4 depicts the floor plan before the renovation. The shopping mall housed a snack bar (number 1), a café (number 2), a hair dresser (number 3), a bank (number 6), a bakery (number 7), a women's clothing shop (number 8), Plus chain supermarket (number 9), a drug store (number 12), Jan Linders chain supermarket (number 13), a candy shop (number 14), a clothing and household shop (number 15), and a bookshop/post office annex (number 17). While I was doing fieldwork, number 4 and 16 were empty, while some stores (the bank, the clothing shop, Plus, and the candy shop) closed down during this period, either due to the renovation or bankruptcy. On June 12, 2012, Dost Market opened its doors to the store located in number 5.

\subsection{Grocery practices at Dost Market}

\section{Staff members of Dost Market and their practices}

Dost Market is a family-run supermarket owned by two brothers and their cousin. The name of the supermarket potentially gives away that this family is of Turkish descent, since dost is the Turkish word for 'friend.' In fact, the brothers and owners, Ihsan and Seyit, were born in the province of Ağrı, district Eleşkirt, located in the east of Turkey, bordering Iran to the east. As Seyit informed me during our interview (February 7, 2014), the province may be regarded as an area where inhabitants are predominantly of Kurdish descent, as is his family. Due to the Turkification policy pursued during Atatürk's reign in Turkey, Kurdish people were expected to learn the Turkish language in addition to the Kurdish Kurmanci and Zaza languages (Dorleijn 1991: 75; El-Aissati et al. 2005: 151-152). The family of Ihsan and Seyit learned Turkish as well as Kurmanci, which they usually used at home (Interview with Seyit, February 7, 2014).

In order to deal with high labor shortages, the Netherlands settled on a recruitment agreement with Turkey in 1964 (Den Exter 1992: 19). ${ }^{58}$ The recruitment agencies in the Netherlands maintained close contact with employment offices in Turkey. Most workers were recruited from the Central Anatolia Region of Turkey (ibid), whereas Europe as a whole only recruited $8 \%$ of their guest workers from the eastern provinces of Turkey, where most people of Kurdish descent live (Dorleijn 1991: 76). The father of Ihsan and Seyit might thus be regarded as an exception, since he left Turkey to work as a so-called 'guest worker' in the Netherlands (Interview with Seyit, February 7, 2014).

As was the case for many guest workers at that time, Seyit and Ihsan's father did not return to Turkey, in contrast with the Dutch government's expectation when initiating the recruitment (Van der Heijden 1991: 232). From the 1970s onwards, family reunification started, with a peak period between 1974 and 1979 (ibid). In 1983 the Dutch government officially declared the Netherlands as a country of immigration, while at the same time restricting admission policies (ibid: 233). Possibly due to this stricter policy, Seyit's father was reunited rather late, in 1987, with his spouse, four sons, and three daughters, and the family continued to live in Roermond. After the completion of Turkish

\footnotetext{
58 In 1969 the Netherlands settled on a similar recruitment agreement with Morocco.
} 
family reunifications, "the Turkish community in the Netherlands (...) supposedly better organized [themselves] than the Moroccan and the Surinamese communities" (Jongenburger and Aarssen 2010: 294). Examples of this are the setting up of 'Turkish' stores and the building of 'Turkish' mosques, enabling people in the Netherlands who value and affiliate with their Turkish descent and background to orient towards Turkish culture, language, and cuisine. In my view, one cannot make such generalizations for such a large 'community' consisting of many individuals, each with their own preferences and affiliations. With regards to Dost Market, it is important not to take these generalized ideas for granted, since the family that runs the store is not 'just' Turkish but also Kurdish. Moreover, I will show that Dost Market is not exclusively aimed at 'the Turkish community,' as Jongenburger and Aarssen (2010) refer to it, but at a much larger customer base.

After completion of their studies and having been employed elsewhere, Ihsan and Seyit decided to start up a supermarket in De Donderberg neighborhood. Ihsan and Seyit were in charge of the daily management of the supermarket. Their cousin joined them as a shareholder primarily for administrative reasons; during my fieldwork I only worked with him a few times. Besides them, other staff members (some of them also family members of Ihsan and Seyit) worked at the store. Some of them had more or less fixed tasks, while others helped out where necessary. The tasks within the supermarket were thus rather flexible; no one ever did just one task. If assistance was needed in another part of the shop, employees were asked to help out. Yet there were some main occupations that were carried out by the same individuals throughout the workday. ${ }^{59}$

Co-owner Seyit could be regarded as the main character for this part of my research, since I worked with him most of the time. Seyit - 29 years old at the time we met - was the passionate floor manager of the supermarket. In the morning, his work consisted of either stocking shelves and reorganizing the display of products or handling the cash desk, in those instances when the cashier started at noon. While performing these tasks, Seyit had many interactions with customers. He not only answered questions about particular products but also gave customers advice on what products to use for a particular dish. Moreover, he bantered and caught up with customers while also helping some of them with other non-supermarket-related things (such as translating letters or loading money onto cell phones). In this sense, Seyit's interactions with customers differed from the butcher's or cashier's interactions with customers, since they often had to hurry in order to help the next customer in line. Seyit was usually in charge of the cash desk in the mornings (from 8:30 a.m. until 12:00 p.m.), when it was not yet that busy. From noon onwards, wholesalers' deliveries started to arrive that needed to be checked and accepted by Seyit. Due to the small size of the storage in the back, most of the deliveries had to be transferred to the shop and placed onto the shelves immediately. It was then that the stress level in the shop increased, because this coincided with an increasing number of customers visiting the supermarket. Despite the stress, Seyit generally interacted with either customers or employees to instruct them. Due to his freer interaction with customers, I mostly, but not exclusively, helped Seyit with his tasks in order to record these interactions with customers. Therefore, I describe his life history in more detail than those of the other staff members.

\footnotetext{
${ }^{59}$ It should be noted that the descriptions of these main occupations reflect the situation at the time of my fieldwork. At the time of writing, some occupations are carried out by other people.
} 
When his family was reunited with his father in the Netherlands in 1987, Seyit was 4 years old (Interview, February 7, 2014). From that time onward, he has always lived in Roermond, where he attended primary school, high school, and obtained professional education. After this, he studied Management, Economics, and Law at an applied university in Eindhoven (half an hour by train from Roermond). Until he and his brother started the supermarket together, Seyit's previous work at several places taught him that he did not want to work for a boss; being a floor manager was therefore probably an ideal occupation for him. In this role, he always tried to place products in better and more visible ways. Seyit came across as an intelligent man interested in his surroundings, depending on his mood and the stress level within the shop. He was regularly willing to discuss with and teach customers and employees - including me - about, for instance, Islamic rituals and traditions (for example, about Judgment Day and the exact date of the Feast of the Sacrifice), expressions in different languages (for example, that barkie means a hundred euros), and language systems (for example, that Kurdish is part of the Indo-European language family and shares many similarities with French). His occupation as shop manager enabled me to get to know Seyit much better than the other staff members, who seemingly always had a queue of customers waiting or who were out of the store, as was the case with his brother, Ihsan.

My interactions with Ihsan - 38 years old at the time we met - usually took place during his breaks, when he was having coffee in the back of the store or outside. Compared with Seyit, our contact was less intense. One of the reasons was that Ihsan left Roermond in the morning to buy the supermarket's fruits and vegetables at the trading hall in northern Limburg. Upon his return, he had to hurry to stock the fresh products in the booths and to adjust their prices to that day's deal. After completing these tasks, Ihsan assisted in the butchery. At the end of 2014, when my fieldwork was over, Ihsan started working as the store's butcher. It was then that my contact with Ihsan slightly intensified, when I would visit Dost Market frequently as a 'regular' customer. ${ }^{60}$

Deniz - 26 years old at the time we met - is a cousin of Seyit and Ihsan who was employed as the butcher of the supermarket. Deniz was born in The Hague, but his family moved to Roermond when he was still a baby. Before working at Dost Market, he was a butcher in a similar supermarket located in Eindhoven. In the butchery, the mornings were normally used for preparing orders, seasoning products (such as shawarma, olives, and chicken breasts), deboning and grinding meat, unpacking the wholesaler's delivery, and displaying all the different types of meats in the counter. In the afternoon, as the number of customers increased, Deniz mainly helped customers and, simultaneously, ground meat. During these busy times, Ihsan mostly assisted and helped the customers, while Deniz prepared and fetched meat from the storage refrigerator.

Deniz's cousin Sevim - in her early twenties - was the full-time cashier of the supermarket. She is not related to Ihsan and Seyit. One month after the opening, right after she had finished her accountancy studies, she started working in the supermarket.

\footnotetext{
${ }^{60}$ I deliberately put 'regular' in quotation marks, since I do not think that I will ever feel like a regular customer when going to Dost Market. Even when visiting the supermarket now, I am still attuned to how things are being said and done. Also, when I shop at Dost Market, Ihsan and Seyit sometimes reminisce about the time that I worked with them and ask when I will come back. Furthermore, they often remind me about the pressing deadline of my dissertation by asking how long it will take for me to finish my book.
} 
Sevim usually started to work in the supermarket at 8:30 a.m., and her main tasks were to handle the cash desk and to pack customers' groceries into plastic bags - a task I often took over while there. In the morning, when there were not yet too many customers, Sevim cleaned the cash desk or the floors of the store. Near closing time, she sometimes assisted her cousin, Deniz, in cleaning the butchery.

Besides these staff members, other persons regularly supported the staff. Among these were Ihsan and Seyit's two older brothers. The eldest brother helped Ihsan out with stocking the vegetables and fruit after he arrived from the trading point. The second eldest brother, a taxi driver, joined Ihsan in stocking vegetables and fruits or cleaning the shop here and there on an irregular basis. Dost Market also worked together with students of business or management. These students were able to do internships at the supermarket for a period of six months maximum to learn about running a business. Over the course of my fieldwork, two interns started working at Dost Market: Mustafa joined in the beginning of my fieldwork while Demre started her internship at the end of my fieldwork. ${ }^{61}$ During these internships the interns initially stocked shelves, cleaned, and helped out in the butchery, after which Seyit took them aboard to deal with more serious matters within the supermarket, such as the control of deliveries and making orders for wholesalers.

\section{Interior and products of Dost Market}

I enter the shopping mall and walk by the Jan Linders chain supermarket (see Figure 7.4). I greet the woman working at the bakery as I stroll over to Dost Market. I pass by the full booths with fruits and vegetables, which means that Ihsan has already returned from the trading hall. Avocados, cactus fruits, pomegranates, apples, oranges, pears, coconuts, peaches, plums, and huge cabbages are all neatly piled up in blue plastic boxes. Ihsan says hi while stacking banana boxes onto each other to make sure there are enough bananas, as they are on sale for 99 eurocents per kilo. I make way for a customer leaving the store with bags full of groceries and, greeting Sevim at the cash desk, I enter the shop. I pass by the freezers and vegetable booths and say hello to Deniz the butcher, who emerges from the butchery's refrigerator with an enormous piece of what must have been a cow not long ago. In the aisle with canned food, Seyit seems to ponder how to stack products in such a way that they are visible to customers. He greets me back hastily. The smell of freshly baked Turkish (pides, lavash, and simit) and Moroccan (smida) breads hits my nose as I find my way to the storage room in the back of the shop to leave my bag and to make sure my recorder is correctly adjusted to my shirt and switched on. It is just after 12:00 p.m., and Dost Market is in full swing. (Field notes)

Dost Market was open every day of the week; from Monday to Saturday customers could shop at the supermarket between 8:30 a.m. and 6:30 p.m. (7:30 p.m. on Thursdays). During the period of my fieldwork, the shop also opened Sundays between 11:00 a.m. and 5:00 p.m. Figure 7.5 depicts the supermarket and its different sections before the renovation of the shopping mall:

\footnotetext{
${ }^{61}$ Mustafa and Demre are both fictional names.
} 


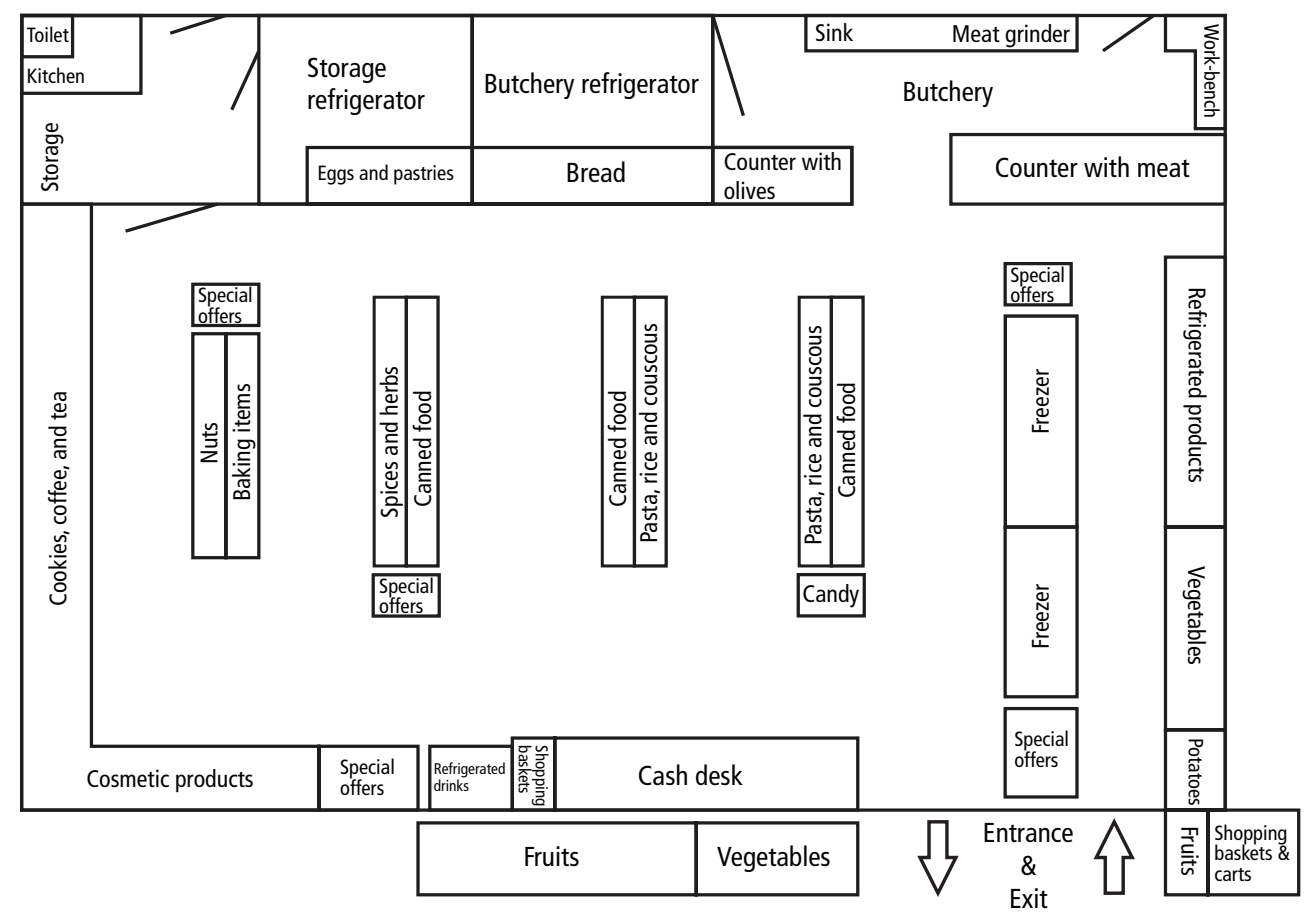

Figure 7.5: Diagram of Dost Market before the renovation of Roermond's De Donderberg neighborhood shopping mall (author's own drawing).

Just outside the supermarket, one could find booths with different kinds of fruits and vegetables. At the time of my fieldwork, the store only had one main door that functioned as both the entrance and the exit of the store. ${ }^{62}$ The freezers and special offers split the door into a makeshift exit and entrance. When entering the supermarket, the first pathway offered vegetables stocked in blue plastic boxes to the right side of the pathway. To the left, freezers were stuffed with such frozen goods as fish, appetizers, and pastries.

Next to the vegetable booth, a refrigerated booth chilled products such as feta cheese, cheese, luncheon meat, and dairy products. The butchery of Dost Market was located at the end of this pathway and was separated from the rest of the store by two display counters and white tiled walls. The counter on the right displayed halal meat. ${ }^{63}$ The butcher sold different parts, primarily of veal, chicken, beef, and turkey, including cutlets, steaks, breasts, liver, ground meat, drumsticks, and chicken wings. Furthermore,

\footnotetext{
${ }^{62}$ After the renovation of the shopping mall, the location of Dost Market's shop premises did not change; only an additional door was added, which became the exit of the store.

${ }^{63} \mathrm{Halal}$ is a term that stems from the Koran and the Sunna to refer to those products that are considered permissible (Bergeaud-Blackler 2006). Un-halal or haram (forbidden) foods are "swine/pork and its byproducts, animals improperly slaughtered or dead before slaughtering, carnivorous animals, birds of prey" (Wright and Annes 2013: 389). Wright and Annes (ibid) explain that halal products are "processed by ritual slaughter of animals through a process called dhabihah. Dhabihah, sometimes referred to as authentic slaughter, mandates the ritual blessing of the animal, followed by the draining of blood without pre-slaughter stunning."
} 
the butchery offered sausages (such as merguez), escalope, seasoned meat (such as shawarma), and, occasionally, rabbit. The kitchen behind this counter was equipped with a meat grinder, a sink, and workbenches. On the left counter of the butchery, different sorts of home-pickled olives and tapas were to be found. The door behind this counter provided entrance to the refrigerated storage where large pieces of meat hung from the ceiling, waiting to be deboned. Next to the butchery there was a wooden rack to stack freshly baked bread delivered daily by a Turkish baker from Roermond. The remainder of the shop was divided by rows of racks that were stocked with instant food, spices, and cosmetic products, as displayed in Figure 7.5. The cash desk was located next to the entrance/exit. Here customers could also get top-up cards for mobile phones.

Special offers of products were usually stacked directly next to the regular aisles, accompanied by handwritten posters to show the name of the product and its discounted price. A few months into my fieldwork, Seyit and Ihsan proudly presented their first advertising flyer to me, which was made by their cousin and the third shareholder of Dost Market (Field notes, December 20, 2012), see Figure 7.6.
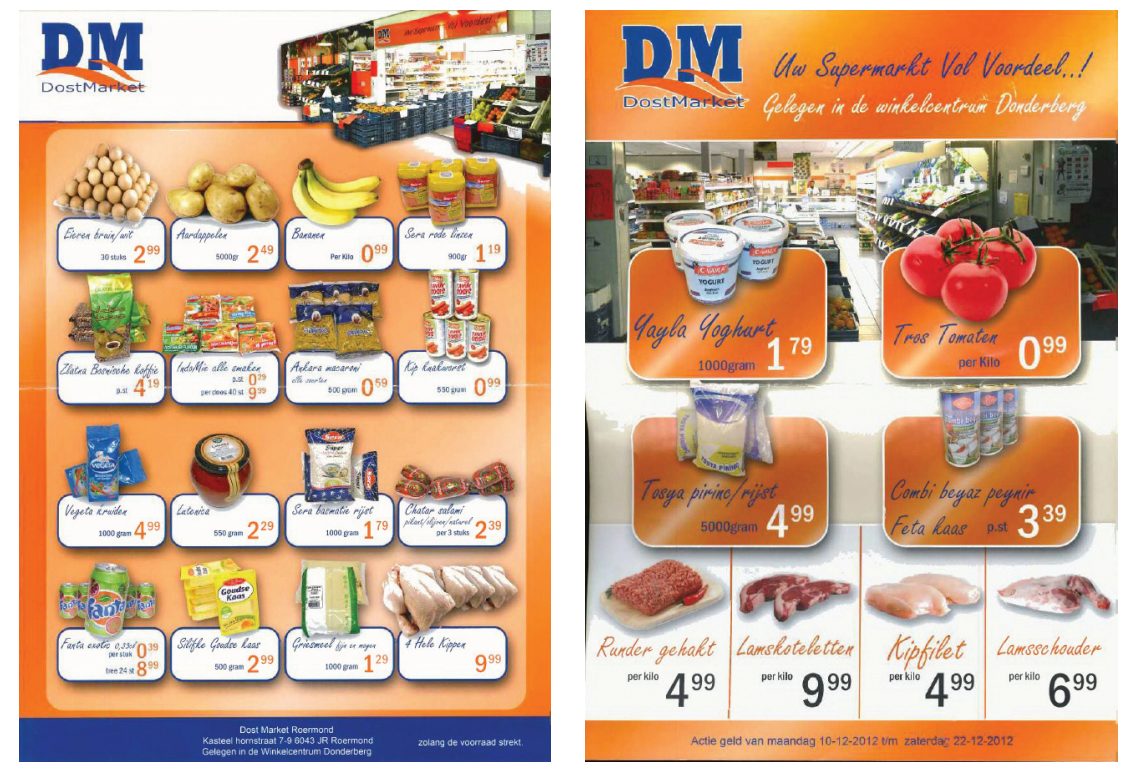

Figure 7.6: Dost Market's advertising flyer as published in December 2012.

The advertising flyers were lying at the butcher's in the supermarket and could be taken by the customers themselves. The flyer shows that out of twenty-four sale products, five products could be regarded as Turkish products. The pictures of the products display the brand name written in Turkish, whereas the advertisement text gives the translation. For instance, the product name tavuk sosis gets translated in the advertisement text as kip knakworst (chicken frankfurter). Seyit was not fully satisfied with the flyer due to some typos, such as the writing of runder gehakt instead of rundergehakt (ground beef) and tros tomaten instead of trostomaten (tomatoes). Moreover, there is a mistake in the sentence at the top of the flyer, gelegen in de winkelcentrum Donderberg (located in the Donderberg shopping mall). The use of determiners in Dutch is dependent on whether a noun is common (determiner de) or neuter (determiner het). The noun winkelcentrum is neuter and 
should be combined with the determiner het instead of de winkelcentrum Donderberg. From the literature, it is known that bilingual speakers of Dutch may struggle with the neuter gender in Dutch, resulting in the overuse of the common determiner de presented above (Cornips 2008). This was the only advertising flyer I came across during the course of my fieldwork. The staff of Dost Market became more active on Facebook in 2017 and started advertising weekly special offers on this social media platform instead. During fieldwork, special offers were mainly promoted within the store by means of handwritten posters.

\section{Customers and their practices in Dost Market}

Obviously, a supermarket cannot survive without customers and customer practices. With Dost Market's location in De Donderberg, a neighborhood with an ethnically diverse resident population, it can be no surprise that the supermarket's customer base was also diverse - as were the customer bases of all stores in the shopping mall. Even though many products at Dost Market were imported from Turkey (see Figure 7.6 and Chapter 8) and the number of customers with a Turkish background was slightly higher, my observations during the nine months of fieldwork point to the fact that Dost Market's customer base was much more diverse than just 'Turkish.' Where large chain supermarkets are constrained by assortment guidelines that are imposed top-down, the owners of Dost Market were able to shape their assortment as they saw fit. Dost Market specifically adjusted their assortment of goods to the assumed backgrounds of their future customers living in Roermond and in De Donderberg neighborhood. When I asked Seyit if and how he had examined the neighborhood before starting up the supermarket, he explained to me:

\section{Extract 3}

Seyit: Of course I did that, what do you think? Obviously. I know the numbers by heart. Here in Roermond, $16 \%$ are allochtoon, out of which $14 \%$ are non-Western allochtoon. This is why my shop aims for Turkish, Moroccan or Arabic people. But also Balkan and Indonesian. When I sell spices that the toko (Indonesian shop) in the city center sells as well, at a cheaper price, then the Indonesians from this neighborhood will come to us and do not need to go to the city center any longer.

(Field notes, July 9, 2012) ) $^{64}$

In this quote, Seyit explained for which customers they were aiming in their early days. For this, he used the labels allochtoon and non-Western allochtoon to refer to customers with Turkish, Moroccan, Arabic, Balkan, and Indonesian affiliations. One day, when I was making an inventory of the store's assortment, Seyit took over my notebook and started drawing how his assortment was ethnically compartmentalized, see Figure 7.7 below:

Figure 7.7: Drawing of the ethnic compartmentalization of Dost Market's assortment according to co-owner Seyit (made by Seyit, December 20, 2012)

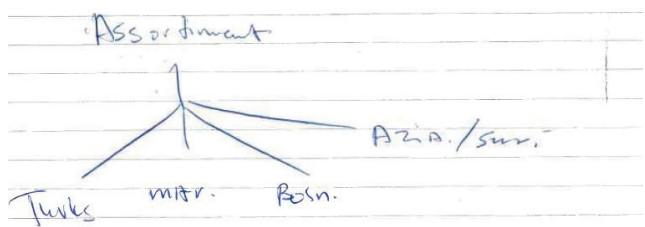

\footnotetext{
${ }^{64}$ A toko is Malaysian for 'shop,' a word regularly used in the Netherlands to refer to an Indonesian shop where they sell Asian herbs, spices, and other culinary products.
} 
According to Seyit, Dost Market's assortment of goods was divided into categories of products that were considered Turks 'Turkish;' Mar., short for 'Moroccan;' Bosn., short for 'Bosnian;' and Azia./Suri, short for 'Asian' and 'Surinamese.' Similar to the study of Pennycook and Otsuji (2016: 272) that found that market traders used the label 'Lebanese' to refer to market stalls that were much more diverse than only Lebanese, Seyit's labels divided his customer base into four bounded and clear-cut sections that blurred the variety of customers that actually bought products from these sections and the varied range of the products within that particular section.

As part of taking their customers seriously, Seyit usually followed up on their suggestions and questions about particular products by writing them down and searching for possibilities to add the products to the supermarket's offerings (see Appendix C for the Interview by Rabobank 2012). This suggests that Dost Market's assortment could be seen as a way to cater to the neighborhood's residents, who were potential customers of the supermarket. I will specifically examine how the intertwined tropes of pride and profit (cf. Duchêne and Heller 2012) or the capital of language (cf. Bourdieu 1991) were used to address customers in Chapter 8.

In some cases, product standards were adjusted depending on the customer who bought that particular product. During my fieldwork, I was regularly taught how to accomplish particular tasks in such a way that it would satisfy customers and, as a result, would increase profit. For instance, Seyit taught me how to place products in visible ways, while Ihsan told me how to write down prices for vegetables and fruits. The following interaction shows how, in some cases, Ihsan and Seyit had particular standards for particular customers and how they taught me 'how things go around here':

It is 1:00 p.m. when I enter Dost Market's storage, where Ihsan and Seyit are having lunch. After a quick greeting, Ihsan accuses me right away: "Hey, did you give that Moroccan woman bad nana yesterday?" Deniz walks in: "Uh, it was a man, and he was full on mad a sahbi (friend in Moroccan Arabic)!" He laughs and walks out of the storage. Lotte: "I gave to a woman, uh, it was a woman or also a man?" Seyit calms the discussion down in a language unintelligible to me, probably Turkish or Kurdish, and adds in Dutch: "Calm down, calm down." Ihsan: "Moroccans, you really should pay atten/ they really pay close attention to that." Lotte: "Yes." Ihsan: "They are really.." Lotte: "Where should I pay attention to?" Ihsan: "Yes, they should be fresh!" Seyit: "Fresh, fresh." Ihsan: "Really get the good ones out of the box." Lotte: "Totally green?" Seyit: "Look, look, if a Moroccan, uh, person walks [in], right, you must always give the best. Always. You know why? They know what's good and especially what's bad." Lotte: "Okay." Ihsan: "The others [nana] are good, too, but they [Moroccans] are just a bit pickier, yes." Seyit: "They take, higher demands." (Recordings, November 2, 2012) ${ }^{65}$

\footnotetext{
${ }^{65}$ Original transcript: "Zeg, had jij gisteren die Marokkaanse vrouw slechte nana gegeven?" Lotte: "Ja?" Deniz: "Eh, man was dat, maar hij was vet boos a sahbi [vriend in (Marokkaans-)Arabisch] [lacht]." Lotte: "Ik heb aan een vrouw, eh, was aan een vrouw, ook aan een man?" Seyit: "xxx rustig rustig." Ihsan: "Marokkanen moet je echt opl/ die letten daar heel goed op." Lotte: "Ja." Ihsan: "Die zijn echte.." Lotte: "Waar moet ik dan precies op letten?" Ihsan: "Ja dat die vers zijn," Seyit: "Vers vers." Ihsan: "Echt de goeie eruit halen." Lotte: "Helemaal groen?" Seyit: "Kijk kijk, als een Marokkaanse, eh, persoon loopt, hè, moet je, altijd de beste geven. Altijd. Weet je waarom? Zij weten wat goed is en vooral wat er slecht is." Lotte: "Oke." Ihsan: "Die andere zijn ook goed maar die zijn gewoon iets strenger, ja." Seyit: "Hun pak, zwaardere eisen."
} 
The interaction with Ihsan, Seyit, and Deniz points out how they perceived their customers and exemplifies how they attuned their service and product quality to the assumed backgrounds of customers: if the customer had a Moroccan background, you gave "very fresh nana," since they were pickier than other customers. Obviously, I was not aware of this correlation between staff, customers, service, and product quality. This interaction exemplifies how, thanks to my ethnographic fieldwork, I was able to learn how things go around here (cf. DeWalt and DeWalt 2002) and how to cater to the needs of specific customers.

Another way to cater to the needs of residents of De Donderberg was the halal butcher, which attracted customers with an Islamic background. Given that the central registration of religious affiliation has been abolished since the Second World War, it is difficult to provide the exact number of Muslims living in De Donderberg, Roermond or the Netherlands as a whole. Numbers that are available for the Netherlands are provided by CBS and based on sample surveys that include questions about self-reported religious affiliations and participation. In 2009 these estimates suggested that out of the total population of the Netherlands 5\%, or 825,000 , regarded themselves as being Muslim (CBS 2009). Of these, 37,400 individuals lived in Limburg (Schmeets 2014: 7). Although numbers are lacking for Roermond, the presence of two mosques in Roermond - one where Arabic is used for services and one where Turkish is used - leads me to postulate that the number of Muslims living in and near Roermond is substantial. The opening of Dost Market and the presence of its halal butchery must have been seen as an improvement by Muslims living in or near De Donderberg, since, before June 2012, they had to go to places outside the neighborhood to buy halal meat (Field notes, December 12, 2012).

Yet I observed that customers from various ethnic and religious backgrounds bought their groceries at Dost Market. As was pointed out in the interview with Rabobank, the bank that supported the setting up of Dost Market, the owners of Dost Market were surprised by the influx of 'Dutch' customers (Interview by Rabobank 2012, see Appendix C). For instance, at the end of December 2012, many people, who I assumed had no Islamic background, asked butcher Deniz to set aside turkeys or rabbits to make sure that they would have them before Christmas (Field notes, December 17 and 20). These customers could hardly believe that they had the chance until 6:30 p.m. on Christmas Eve to pick up their requested meat, since most shops in the shopping mall closed at 4:00 p.m. on that day. Even though the influx of these so-called 'Dutch' customers may have increased slightly during the Christmas period, I observed that these customers visited Dost Market regularly throughout my fieldwork. This affirmed what Vlakveld (2005 in Van der Schans et al. 2009: 21) found in a study about 'ethnic' supermarkets and groceries in Germany, in which 'natives' increasingly valued halal meat, due to its price and quality. Moreover, in the Vlakveld study 'natives' declared they preferred 'the Turkish shop,' since shops of this type gave them the feeling of being closer to nature and that they were more artisanal than large supermarkets. I would add to this that in the shopping mall of De Donderberg, the halal butchery of Dost Market was the only artisanal butchery where customers were still able to request a particular product by weight, thus offering an extra service to customers, whereas meat departments at chain supermarkets usually sell prepackaged meat. Moreover, as I will show in Chapter 8, customers came to Dost Market to shop for and experience diversity. 
Customers were able to freely roam around the shop, even without buying something of course, up to a certain point - before being kept an eye on with suspicion. Customers could take most of the products from the shelves of Dost Market themselves. The meat had to be ordered at the butcher's counter and the bundles of fresh herbs (like mint or nana, coriander or kosbor, and parsley or madnous), stored in the walk-in fridge located in the storage room at the back of the store, had to be requested either by going to the butcher's counter or by walking around to find an available staff member who could then fetch it. Like the owners of Dost Market (Interview by Rabobank 2012), I call the store a supermarket. Yet it should be noted that the shop should rather count as a small-scale supermarket, where foods as well as non-foods are sold and where contact and interaction between staff members and customers is required to some extent, since customers have to order or request particular products. At larger (chain) supermarkets, this is not always the case, inasmuch as customers can take all products from the shelves themselves and check out their groceries without having any contact, either at automatic cash desks or simply by wearing headphones and not interacting with the cashier at all.

Generally, the shop became busy from noon onwards, which meant that the staff was obliged to receive deliveries, stock shelves, prepare meat recipes at the butchery, and clean floors and windows mainly in the mornings. At peak times in the afternoons, all staff members were helping customers, either at the cash desk, butchery or within the store. Around closing time, all the materials of the butchery had to be cleaned to make sure they could be used right away the next day. These practices were all directed towards creating a pleasant atmosphere for customers. If customers felt out of place at Dost Market, this would probably equate to not making money, meaning that customers' needs were highly valued by the store's staff members. This catering to customers' needs sometimes went beyond just grocery shopping: some customers came to the store to get Seyit's help with the translation of national administration letters or with the topping up of mobile phone balances (Field notes November 2, 2012 and February 22, 2013). By no means do I suggest that Seyit did this simply for the sake of making profit. What these practices do show is that Dost Market differs from larger anonymous chain supermarkets where it is possible to do grocery shopping without having any interactions.

\subsection{Fieldwork ethics and practicalities}

With regards to ethics, before starting my fieldwork in the supermarket I obtained the permission of both owners to be there. After this, I informed other employees (butcher, cashier, and interns) about my presence. It was not until I started making audio recordings that I officially asked consent from all the employees to record them while being there. I deliberately decided to always carry the audio recorder myself, attached to my own clothing. At first I was planning on placing the recorder at the butchery or giving it to Seyit during his work, while being somewhere else myself, but in the end I realized that this would not work, since I would then miss out on the context of the situated interactions they were engaging in at that particular moment, essential to grasping the meaning of language practices (cf. Gumperz 1992).

The recording practices during my fieldwork at Dost Market differed vastly from my fieldwork during the events at the carnival association of De Katers (Part I). Those events 
only occurred at a specific time of the year, namely the celebration of carnival, which made it more or less legitimate and normal to take photographs and make videos and audio recordings, since many people present at events did so for their own collection as well. In contrast, shopping for groceries at supermarkets is part of everyday life, which means that people usually do not make photographs or video recordings to picture what is going on at a specific time or day. Moreover, going to or working in a supermarket is usually not seen as something special, but as necessary to put dinner on the table - which holds true for both employees and customers. Therefore, in this location, I felt more uncomfortable with note-taking and audio recording, since this deviated from what is considered 'normal behavior.' Once again, the bathroom in the storage room offered a solution to quickly jot down observations or things I heard. When I was making an inventory of the store's assortment on a large notepad, I noticed that staff members and customers did not think of this as strange, since it looked as if I were making an order or a balance sheet. After this, I often brought along a large notepad to be able to note down the time of interesting interactions and happenings, so that I could easily find them back in my recordings.

When sharing personal stories, gossip or opinions, staff members would sometimes ask me to switch off the recorder. Customers of Dost Market were informed about my research through a poster that I put up at the entrance saying that I (picture of myself included) was carrying out research about language practices in De Donderberg neighborhood and that I was listening to interactions in the supermarket that could be used for my dissertation. They were asked to notify me if they refused to be part of the research. Although it is possible that not all customers were aware of the poster, and thus my research, I thought of the supermarket as a public place, where people usually did not discuss sensitive topics. Therefore, I used my own judgment about what and what not to record and use. During participant observation, I mainly held informal conversations, consisting mostly of everyday-life chitchat about particular (global, national, regional, or local) events, customers, and supermarket tasks. I conducted two interviews with Seyit (see Figure 2.3 in Chapter 2 for the Dost Market dataset).

In comparison to my fieldwork at De Katers carnival association, where I did not immediately feel included as an ethnographer, because I was not connected to the association directly, the supermarket as a location was public and freely accessible to everyone who wanted to enter. In the initial weeks of fieldwork, I decided not to make recordings but first to build up rapport or trust with both staff and regular customers of Dost Market. Ihsan and Deniz in particular remained somewhat silent, and it seemed as if they tolerated me yet behaved in a reserved way toward me. I figured it would be best to prove myself through hard work. When Deniz, after a very busy afternoon in which I helped with stocking for three hours, offered me a bag of exotic fruits to take home, it felt as if he had come to accept my presence due to my hard work. After this, I felt that the staff members trusted me, making it much more comfortable for me to turn on the recorder, which I did after more than two months. Through my hard work, Seyit also recognized that I was indeed serious about and capable of dealing with supermarket tasks and that I could also be of (voluntary) help to the store. Upon leaving the store after completing my fieldwork, Ihsan even told me that he thought of me as one of them.

Being in this position meant that I had to balance between two roles, that of employee and of researcher. Whenever I heard something interesting, I had to quit a task to go to the back of the store, where my bag with notebook lay, to write down some notes. Other employees sometimes frowned upon this, since my job seemed to be more optional than 
theirs. Even though they were aware that I was doing research, for some employees this awareness seemingly faded away as time passed. Not for Deniz though. From the day that I started to record in the supermarket, he remained highly aware of this. Therefore, he repeatedly asked, "Lotte, jij nog steeds opnemen? Jij moet betalen mij!" ("Lotte, you still record? You must me pay!") (Recordings, February 22, 2013) - I will return to this specific utterance in Chapter 8.

Due to my appearance (see Chapters 1 and 2), many customers thought of me as being an employee they could approach in Turkish, Moroccan Arabic, or other language whenever they wanted to ask something. When I explained I could not understand any languages other than Dutch, dialect, English, and French, I usually had to explain where I was from and to account for my looks, whereafter some customers concluded that I was, after all, an outsider in this place. Similarly, I was accused of living in "one of those far away and posh neighborhoods" by intern Mustafa, since he had never seen me around De Donderberg neighborhood before, where I had actually lived for the first eighteen years of my life. Further, my university degree also seemed to be an aspect that hampered my inclusion amongst the employees, especially for the butcher, who often addressed me as professor or chef. I therefore decided not to talk about my work too much, for instance, that I was teaching at the university. Lastly, the sliding door between the shop and the storage in the back occasionally functioned as a way to keep me out of particular business that was not intended for my ears. I respected this and stayed away from the storage whenever I saw that they had purposely closed the sliding doors. Nevertheless, at the end of my fieldwork, I felt more and more part of the supermarket. Also, on non-fieldwork days, I was allowed to go into the storage to fetch coriander or parsley for my own groceries. I stopped doing this when my fieldwork time was 'officially' over. ${ }^{66}$

\section{Conclusion}

This chapter presented the context of the small supermarket of Dost Market located in the shopping mall of De Donderberg, a neighborhood in the eastern part of Roermond. I conducted ethnographic fieldwork at Dost Market for nine months, in addition to the other two research cases, since the grocery practices in the store provided valuable insights into how people give meaning to places and the interactions they have with others. I have described Dost Market's location, interior, and products as well as introduced the practices of the main staff members and customers. At Dost Market, staff members and customers of various ethnic, religious, and linguistic backgrounds came together. I argue that this fieldwork site is a case in point to emphasize that perceived peripheral areas, such as Limburg province and De Donderberg neighborhood, should not simply be understood as culturally and linguistically homogeneous areas lacking in diversity. This chapter has prepared the way for Chapters 8 and 9. In Chapter 8, I will examine the place-making practices found at Dost Market that helped to shape the store as a place with particular routines. In Chapter 9, I will closely analyze how politics of (un)belonging emerged during an interaction between Seyit and a customer.

\footnotetext{
${ }^{66}$ I write 'officially' deliberately, because still, at the time I am writing this in 2017, whenever I visit Dost Market as a customer, I tend to tune into what I see and hear around me and take into account new developments, such as interior and staff changes.
} 


\section{Chapter 8}

\section{Where kapusta is a greeting: Negotiating foreignness and place- making through languaging at Dost Market}

\section{Introduction}

In the research case of David and Zeegert (Chapter 6), it became clear that the men, who were both born outside Limburg, felt a sense of belonging with one another and with other people born outside the province based on their feeling of unbelonging within Limburg. In this chapter, I will present snapshots from the supermarket that show how people at Dost Market often started interactions by "deciding whether they [stood] inside or outside the imaginary boundary line of the (...) communities of belonging, whether they [were] 'us' or them'" (Yuval-Davis 2006: 204). Similar to David and Zeegert, I argue that some staff members and customers at Dost Market would often engage in trying to figure out whether the people they met stood inside or outside the imaginary boundary line of the communities of unbelonging; unbelonging rather than belonging was the focus of their concern and their effort at establishing commonality. In Section 8.1, I call this phenomenon of belonging through unbelonging, that I already encountered with David and Zeegert, foreignness.

At De Katers it became clear that people used linguistic forms that were enregistered as dialect or Dutch. Most of the time, though, the members of De Katers used dialect; it was only when routines were broken that Dutch was used, as was the case with the entrance of Sinterklaas during the prince announcement event (Chapter 5). David and Zeegert (Chapter 6) used linguistic forms that they had acquired over the course of their lives, including forms that produce localness in Limburg. The concept of languaging (Jørgensen et al. 2011; Møller \& Jørgensen 2009) applies to both research cases to reflect the ways that people use language as a resource from which they draw specific linguistic forms depending on the communicative goals, situations, places, and the moments in their life (cf. Jørgensen et al. 2011). Consequently, the concept of languaging dissolves fixed connections between language use, place, and identity (cf. Quist 2010), meaning that the use of dialectal forms in interaction is not restricted to just 'native-born' Limburgers, as the case of David and Zeegert showed before. This chapter will show that at Dost Market it is equally hard to make fixed connections between language, place, and identity, since staff and customers engaged in languaging by using linguistic forms that could be associated with more varieties than just Dutch. Staff members as well as customers used wide ranges of linguistic forms acquired through their individual life trajectories in order to interact within an environment where routines of language practices or 'register-routines' were not necessarily clear from the start. In comparison with De Katers, where dialect was deemed to be the appropriate language variety to use for carnival celebration - although the actual practice showed that these routines could be broken - such routines were not always established at Dost Market. Dutch was not always the obvious language to use: for example, with customers who were not fully proficient in Dutch or dialect. This left room for explorations and improvisations that, in their turn, produced new routines: the use of the Polish kapusta to greet customers with a particular assumed language background, as well as the use of Moroccan Arabic mazyan, nana, and kosbor. 
My intent is to examine how people shaped understandings (cf. Gupta and Ferguson 1997) of Dost Market by attaching linguistic forms to its place, thus engaging in place-making processes (cf. Cresswell 1996; Pred 1985). By studying the spatial repertoires (cf. Pennycook and Otsuji 2014ab) employed within Dost Market as a place, I hope to be able to provide insight into the place-making practices occurring in the supermarket. On the one hand, in Section 8.2, I scrutinize linguistic forms as they were used and appeared within the situated interactions of Dost Market. I analyze greeting and parting routines between staff members and customers, elaborate on the fun and friction of languaging in practice, and pay some attention to the use of dialect in the store. Section 8.3, on the other hand, addresses how spatial repertoires were displayed in the linguistic landscape of Dost Market by looking at (handwritten) advertisements and price tags, notices, and the use of images. As pointed out in Chapter 4 (Section 4.2), linguistic landscaping (cf. Landry and Bourhis 1997) is highly valuable in examining processes of place-making. Yet in accordance with Pennycook's and Otsuji's (2014a) idea of spatial repertoires, I expand the linguistic landscape paradigm, which only examines the display of linguistic signs in particular (public) places, by including the use of linguistic forms in verbal interactions. It is in dialogue with these actual interactional practices that written signs were produced and vice versa, thus actively co-constructing the spatial repertoire of a particular place. As a result, this chapter will show how language and cultural practices transformed Dost Market into a place that allowed customers and staff members to use whatever linguistic form they saw fit in a particular context and to negotiate, reproduce, and construct politics of (un)belonging including shared feelings of foreignness or belonging through unbelonging.

The interactions I heard and participated in at Dost Market reflected manifestations of languaging practices that have often been overlooked. While many studies have approached these languaging practices by examining instances or situations where various linguistic forms are used (for example, the mixed use of Dutch and Moroccan Arabic forms), few studies have examined the use of linguistic forms enregistered as dialect (such as dialects in Limburg) alongside, for example, Dutch, Moroccan Arabic, and Turkish forms. Jaspers' studies $(2004,2011)$ of Moroccan youngsters in Antwerp are the main exception. In these studies, it becomes clear how these youngsters engaged in and related to languaging practices in which they made use of Flemish Dutch, stylized Dutch, Arabic, Berber, and Antwerp dialect. Jasper carefully points out how the youngsters used the different linguistic forms to construct images of self and other. It is at Dost Market that these linguistic forms, that are generally associated with local, regional, national, and global levels, encountered one another and produced a place where a large range of linguistic forms could be used while shopping for groceries. In combining the study of spatial repertoires in verbal interaction and on display, this chapter adds to the reader's understanding of what kind of place Dost Market was at the time of my fieldwork. The focus on a supermarket located in Limburg underscores the fact that linguistic and cultural diversity are not only found in perceived central and urbanized areas, but also in perceived peripheral areas, as suggested by DeLima (2012) and Wang et. al. (2013). 


\title{
8.1 The construction of foreignness
}

\author{
Practices in a 'foreign shop'
}

During my first day of fieldwork at Dost Market, Seyit gave me the lowdown on the shop, its products, and its customers, while also pointing out an annoying aspect of working at Dost Market in Extract 1:

\section{Extract 1}

Seyit: The annoying thing about a buitenlandse winkel (foreign shop) is that people always try to get a discount. They would not do that at Plus or Jan Linders, because there they display the fixed price of the product. I do that too, nevertheless people suddenly say about something that costs 1,25 euro: "Give me that for 1 euro." (Field notes, July 9, 2012)

According to Seyit, people thought that they could get away with particular practices and behavior due to the fact that Dost Market was perceived as a "foreign shop." Seyit's comment indicated that customers perceived Dost Market as a place where they could get away with particular practices and behavior in comparison to other shops, like big chain supermarkets Plus or Jan Linders, where people would not consider trying to bargain for a discount. Similarly, it is unlikely that customers would go to big chain supermarkets to receive help with the translation of national administration letters or with the topping up of mobile phone balances, as some did at Dost Market (see Chapter 7). It is through place-making practices that people perceived Dost Market as a place that was 'foreign' and where particular practices would be considered 'normal' or in place (cf. Cresswell 1996). Similarly, staff members as well as customers thought of Dost Market as a place where it was appropriate to use linguistic forms associated with diverse languages in their interactions.

I will first elaborate on the label 'foreign' as an emic term used by Seyit, since this designation inspired me to define the analytical concept of foreignness. Seyit's reference to "foreign shop" was the first time that I had explicitly heard someone use 'foreign' during my fieldwork at Dost Market. Soon after I observed that being 'foreign' or not was an important issue among staff and customers and therefore part of the place-making practices at play in this place. These practices achieved similar forms of belonging through unbelonging in which shared feelings of unbelonging within a particular place evoked a feeling of belonging together. I will propose the concept of foreignness to refer to this form of belonging through unbelonging, which was as relevant within the context of Dost Market as it was, in hindsight, for the research case of David and Zeegert (Chapter 6).

During my fieldwork at Dost Market, some customers expressed their feelings of being out of place in this perceived "foreign shop" by explicitly asking questions about, for them, unknown products. It is in this sense that these types of shops are often described as places where people may shop for and experience diversity (Pennycook and Otsuji 2014a: 164). Related to this, I found that some customers, who would be described as 'native-Dutch,' perceived the store as a place where they could learn about other customs and products from cuisines other than the mainstream products affiliated with the Netherlands, Italy, Spain, France, India, etc. For instance, customers would ask about products "hoe noemen jullie dit?" ("how do you (plural) call this?") or "wat doen jullie hiermee?" 
("what do you (plural) make of this?") (Field notes, November 15, 2012 and February 22, 2013). In this utterance, "you" is a plural pronoun referring to 'you people as a group.' These types of utterances not only construct boundaries between 'us' and 'them,' they also show that, by asking such questions, these particular customers acknowledged being out of place within Dost Market due to a lack of knowledge and implied the existence of an alleged 'group of people' (indicated by the plural you). Such questions added to the perceived foreignness of the shop.

\section{Belonging through unbelonging}

While working at Dost Market, I myself quickly found out that my own embodiment served as a great tool to experience how staff as well as customers tried to figure out whether we shared particular language practices and feelings of (un)belonging. I described earlier how my dark-eyed and dark-haired looks are generally interpreted by others - both within the province of Limburg and within the Netherlands as a whole - as deviating from 'the' norm (Chapters 1 and 2). While working at Dost Market, it seemed that my appearance confused both staff members (at first) and customers. Customers were often in doubt about what language to use when approaching me and, possibly, whether I could be regarded as 'one of them,' thereby revealing how language practices are embodied and 'raced' by connecting particular language practices to particular bodies and phenotypes (Alim et al. 2016; Bucholtz and Hall 2016). What usually followed was a 'guessing game' about my background. The following examples of encounters taking place at Dost Market exemplify the method behind 'sensory ethnography,' which explicitly asks for reflexivity on embodied ethnographic experiences and the ways that an ethnographer "learns and knows through her or his whole experiencing body" (Pink 2009: 25). It is important to emphasize that if my appearance had been different (e.g., blonde hair, blue eyes, and light skin color) or I had different language skills (e.g., the ability to speak and understand Moroccan Arabic or Turkish), I would have collected material that probably would have constructed a different image of Dost Market - thus revealing the contextual nature of relations between embodiment, language, and place-making.

My first encounter with Yassine ${ }^{67}$, a regular customer who visited Dost Market almost everyday, is an example of how my own embodiment became the subject of a guessing game:

Yassine approaches Seyit and me and greets us: "Salaam aleikum." Seyit: "Aleikum salaam, a goujja [brother]." I politely smile at Yassine and greet him with a Dutch hallo (hello). He looks at me with squinted eyes and asks in Dutch: "Are you... Are you... You are not Turkish, are you?" "No, I am not." "I thought so already, but nevertheless you have black eyes and black hair. Are you ordinary Dutch?" After I explain where I got my looks from, he continues his daily small talk with Seyit.

(Field notes, September 20, 2012)

\footnotetext{
67 Yassine is a fictional name.
} 
My appearance (in Yassine's words, "black eyes and black hair") in combination with the Dutch hallo instead of aleikum salaam must have been reason enough for Yassine to guess at my background. In other instances, the guessing game started after a customer had addressed me in a language other than Dutch, and I made it clear that I had not understood him or her. When this happened in the presence of Seyit or Sevim, they occasionally responded for me in Turkish or Kurdish, explaining that I was an intern and that I was Dutch. On one occasion a man could not believe this and exclaimed: "I really thought you were either Moroccan or Turkish!" (Field notes, December 17, 2012). In my opinion, these guessing games could be seen as attempts to bond with me as someone who had or did not have something in common with the particular customer, whether it was a common language to interact in and/or a heritage from outside the Netherlands.

Butcher Deniz provided another example of this bonding when we were working together at the butchery:

Dost Market is nearly closing, and I quickly help Deniz to clean the butchery. While showing me how to clean the meat grinder, he says: "That's how foreigners do it! Are you a foreigner too?" Me: "Half." Deniz: "Half does not exist anymore, then you are a foreigner."

(Field notes, December 17, 2012)

This interaction with Deniz is interesting for several reasons. First, looking at this interaction from a sensory ethnographic viewpoint (cf. Pink 2009), it becomes clear that I used my own body in different ways during this research. In the interaction with David and Zeegert (Chapter 6, Section 6.4), I stated that I was "half Dutch," after which I immediately started to defend my legitimacy as someone born and raised in Roermond who had learned dialect. With Deniz, I did not provide this extra information and stated that I was 'half a foreigner' instead of half Dutch. Apparently, I decided to explain and defend my appearance differently due to the different ethnographic locations I found myself in at those moments and to make a place within each setting (cf. Pink 2008). In this sense, my own embodiment and the way I emphasized it could be seen as a strategy to feel included in the different ethnographic locations of this research. This clearly illustrates that "the cultural context of 'where you are at' always informs and articulates the meaning of 'where you are from"" (Ang 1994: 35): with David and Zeegert, I emphasized that I was from Roermond; with Deniz, I emphasized my 'half foreign' aspect. Yet Deniz did not acknowledge 'half foreign' as being a fair label. ${ }^{68}$

Second, Deniz's statement made me realize that, according to him, one could never be 'half a foreigner'; you were either a foreigner or you were not. Besides this, the quote seems to be a reference to Deniz's thoughts about society in general, due to "half does not exist anymore." It raises questions about why 'half a foreigner' does not exist any longer; is it, for example, because of the current polarization within Dutch society? Generally speaking, "foreigner" (buitenlander) is used in the Netherlands to talk in a pejorative way about 'the other.' The current political climate of many (West European) countries, with the increasing popularity of right-wing and populist parties, seems to strengthen the polarization

\footnotetext{
${ }^{68}$ I am indebted to my colleague, Jolien Makkinga, for pointing this out to me and making me realize how I presented myself differently in both fieldwork contexts.
} 
between so-called 'natives' and 'non-natives,' whereby the latter group may experience feelings of exclusion. In the Netherlands, the influx of migrants and the accompanying feelings of estrangement have led to debates and policies about who belongs in the country and why, also referred to as the 'crisis of home' (Duyvendak 2011). The preoccupation with and debates about roots and autochthony can also be found in other immigrant countries such as Luxembourg, Belgium, France, and Sweden (see Geschiere 2009 for European and African examples of discussions about belonging). An exclusive, tacit, vague, and all-encompassing description - or as Geertz (1973) would call it, a thick description - of Dutchness makes it hard for immigrants to integrate within Dutch society and equates Dutchness with the 'native-Dutch' majority (Ghorashi 2002). As a result, an endless debate has evolved about the identities, loyalties, and meanings of the national 'home' (Duyvendak 2011:2). Feelings of othering are, according to Ghorashi (2002), the result of the ambiguous history of migration of contract workers to the Netherlands. Since the idea was that migrants would eventually return to their homeland, migration was perceived as something temporary. In actuality, these returns never took place, and the expectation of an eventual return to 'the homeland' no longer applies to current migrants. Yet the idea is still rooted in Dutch society and results in a repetitive process of othering, in which the 'native Dutch' continuously ask people they consider as 'the other' questions such as 'where are you really from?', a question which usually follows the earlier answer 'from the Netherlands.'

Finally, the quote shows how Deniz, by asking "Are you a foreigner too?", tried to bond with me as having 'something' in common: a heritage other than Dutch. In this sense, my encounters with Yassine and Deniz were similar in that both men aimed to find out whether we had 'something' in common so that we could bond.

\section{Appropriation of the term foreigner}

In the Netherlands, the label buitenlander (foreigner) usually carries pejorative connotations. At Dost Market I regularly observed that the label of foreigner was used by those people usually perceived as 'the other,' referring to themselves thus, however, without these negative connotations, thereby appropriating the term altogether. ${ }^{69}$ This allowed for a situation where being buitenlander (foreign) was not automatically regarded as a deficit or something negative, but rather as something that served to bond and allow for personal and closer contact. This means that staff members as well as customers felt safe enough within this place to play with a label that, from a national perspective, was an otherwise negative term:

Outside the storage stands a large pallet with goods on it that has just been delivered. I join Seyit to unpack the goods. Seyit first grabs the invoice and starts checking the delivered goods. Halfway through he decides to stop: "Well, never mind, a Dutchman did this, so it must be in order. When a foreigner delivers something, you must always check it. Foreigners cannot be trusted." We walk inside the storage where intern Mustafa stands and has overheard Seyit's statement. Seyit raises

\footnotetext{
${ }^{69}$ In my field notes, I found that Seyit and Deniz used the term buitenlander on various occasions, i.e., on September 20, 2012, November 22, 2012, December 17, 2012, January 10, 2013, February 22, 2013, and March 7, 2013.
} 
his voice: "Isn't that right? Koolchi Arabiya (everything Arabic)! What are you doing, man? You have to do that foreign style, not Burberry [an expensive clothing brand] style. This is Dost, not Burberry."

(Field notes, September 20, 2012)

In this observation, Seyit first related to the pejorative meaning of the label foreigner when claiming that foreigners could not be trusted and that, as a shop owner, you always needed to check deliveries received from foreigners. Yet in talking to intern Mustafa, 'foreign' became a way of doing something that carried with it a certain pride: the pejorative label was appropriated into something prideful. I argue that, in relation to Mustafa, Seyit wanted to present 'foreign' as something positive in contrast with his previous statement about foreign deliveries. Furthermore, by using the term "foreign style," Seyit tried to relate to a certain style that both he and Mustafa could affiliate with due to their similar 'foreign' background.

\section{The need for foreignness}

How can the search for belonging through unbelonging within Dost Market be explained? For an answer to this question, I want to refer to my ethnographic research in the former fishing village of Volendam, located in the north of the Netherlands (Thissen 2010). When I was participating in a painting class for elderly women, it became clear that I was not perceived as 'Dutch' or 'Roermonds':

\footnotetext{
While the women are painting, I chat with them and listen to their exchange of local gossip in Volendam dialect. Participant Gaar was not talking to me that much, even though she was carefully listening to what I was saying, and I felt that she kept track of who I was talking to. After noticing that she was the only one not talking to me, she decided she wanted to know more about me and, more important, where I came from. "Tell me, where do you come from?" "I come from Roermond." "Yes, okay, you said that already. But really, because in Roermond people are not as dark as you are" (Thissen 2010: 34).
}

I argue that it is exactly this atmosphere of 'othering' - applied to everyone who happens to have an appearance that is perceived as 'different' - that strengthens the need for a shared feeling of foreignness: a feeling of belonging through unbelonging. Just as Gaar from Volendam tried to figure out where I really came from, I experienced in the supermarket that those who were considered to 'unbelong' or to be 'the other' tried to figure out whether there was a basis for bonding with someone else who was also regarded as unbelonging or as an 'outsider.' For example, sharing a background other than 'native-Dutch' or 'native-Limburgian' might thus possibly allow for people to be on a friendlier footing when they meet.

Gaar's questioning of my origins and appearance when I attended her painting class in Volendam as well as Yassine's and Deniz's questioning at Dost Market are illustrative of the processes of othering. These persistent processes of othering (Ghorashi 2002), the supposed crisis of home (Duyvendak 2011), and anti-immigrant statements (Prins 2002) enforce the need for shared foreignness among those who feel excluded by society and politics, potentially nurturing feelings of belonging among them. Dorleijn and Nortier 
(2005) point to a similar feeling of solidarity among youngsters from families with backgrounds other than 'native-Dutch.' The youngsters did not identify as being either Turkish or Moroccan, but did identify with the overarching notion of being foreigners. This resembles, according to Dorleijn and Nortier, the colonial situation in the West Indies as described by LePage and Tabouret-Keller (1985), where the separate island identities were covered by a collective West Indian identity that was constructed against the common enemy of the United Kingdom. In both cases, feelings of foreignness were constructed among a group of people generally perceived as 'the other' on the basis of difference, be it appearance, language practices, or religious affiliation.

\section{The analytical concept of foreignness}

The above described search for belonging through unbelonging is what I analyze and propose to call foreignness, which I define as a feeling existing between two or more persons based on some kind of shared otherness in comparison with others who define themselves as 'natives' or as naturally belonging to the place where they live. These so-called 'native' people usually consider the so-called 'non-native' others as newcomers or outsiders within a specific place (country, province, city, or as local as a carnival association or supermarket) due to their 'origins. ${ }^{170}$ Yet these allegedly 'non-native' people may very well have been born, raised, and/or living in that place for a lengthy period of time. Foreignness reflects the need that people may have to decide whether their interlocutors are in a position comparable to theirs: due to their imagined otherness, they are perceived by others as not belonging in a particular place. Foreignness can thus be seen as a kind of belonging (through unbelonging), since it imagines that a group of people has something in common that is off limits to others (cf. Alborn 2001). In this sense, foreignness is an imagined collectivity, an imagined community, so to speak (cf. Anderson 1983), that is constructed amongst people through language and cultural practices.

In academic literature, scholars use the term foreignness in order to describe someone's otherness (Holly and Meinhof 2013). Moreover, the term can be used to show how 'a' language, such as Arabic, indexes foreignness, whereas Dutch would index national Dutchness (Kremer 2015; Van Avermaet 2009). In both cases, foreignness is taken as a state of being that is ascribed to research participants that presumably have a migration background. Yet what is important to highlight is that - from my point of view based on my fieldwork experiences - foreignness refers to a feeling that can be constructed at any time and place, and, more important, by anyone - not only those people who are, in common discourse, regarded as 'non-native.' Thus, foreignness is a cultural construct that is only relevant in cases where people can compare each other with so-called significant others, which also holds true for cultural constructs like ethnicity (cf. Barth 1969). In other, rather more excessive, words, foreignness assumes shared commonalities against a shared 'enemy.'

I have shown in this section that figuring out shared feelings of unbelonging, foreignness, was part and parcel of place-making processes at Dost Market. In Sections 8.2 and 8.3, I will focus on linguistic place-making practices whereby various linguistic forms

\footnotetext{
${ }^{70}$ I derived the inspiration to use the term 'foreignness' - instead of 'foreignership,' which seems to suggest a static state of being - from Kremer (2015), however, the conceptualization and definition of the term are my own and based on experiences and observations within the supermarket.
} 
were attached to the place of the supermarket. I will do so by examining how spatial repertoires were used in interactions and displayed in linguistic landscapes. I argue that verbal interactions should be studied alongside linguistic landscapes, since these interactional language practices are in dialogue with displayed linguistic forms and vice versa, thus making up spatial repertoires as a whole (cf. Pennycook and Otsuji 2014a).

\subsection{Spatial repertoires in use at Dost Market}

During work, employees and I talked with each other and with customers about both supermarket-related and unrelated topics. These interactions, many of them involving greeting or selling and buying routines, should be considered as linguistic place-making practices at Dost Market. These interactions render a place a certain character and atmosphere. The creation of these interactional routines is part of a place-making process whereby linguistic forms are attached to a specific space, thus transforming it into a place where particular linguistic forms are considered appropriate to use in interactions (cf. Cresswell 1996; Johnstone 2013a; Lefebvre 1991; Pred 1985). Through careful observation, I was able to discern how things went around here (cf. De Walt and DeWalt 2002). In this section I will reflect on the staff members' greetings of and partings from customers as well as the fun and friction of linguistically diverse interactions, including the use of dialect, at Dost Market.

\section{Greeting and parting}

In general, most interactions started with polite actions, such as inviting, greeting, enquiring, asking, or offering (Rehbein and Fienemann 2004: 227). The polite action of greeting might be just that, a greeting only, or might start off an interaction. When doing their grocery shopping at Dost Market, most customers were greeted either by the butcher when passing by or placing an order at the butchery or by Sevim or Seyit when checking out at the cash desk. In most cases, a greeting was followed by an interaction, either informal or about the exchange of goods (ordering meat or paying for groceries at the cash desk). Since all of the employees themselves lived in Roermond, they knew many customers not only because some were regular customers but also because they had known each other long before ever starting to work at Dost Market. For example, Seyit knew many customers because he had played soccer for a long time at a well-known local soccer association. Where occasional and unknown customers were usually greeted with a simple 'hello,' regular and familiar customers often were welcomed by a more elaborate greeting that depended on the relationship staff members had with that customer. For instance, when Deniz would see a customer that also lived in his neighborhood, he would shout: "Hé, buurman!" ("Hey, neighbor!") After Deniz's umpteenth 'neighbor greeting' of that day, Ihsan remarked: "Hold on, is this a neighbor again as well? Deniz, you call everyone neighbor! In my opinion, a person can have a maximum of three neighbors: left, right, in the back. Unless you live in an apartment block" (Field notes, August 3, 2012). ${ }^{71}$ In instances

\footnotetext{
${ }^{71}$ Original transcript in Dutch: "Wacht even, is dit ook weer een buurman? Deniz, jij noemt iedereen buurman! Naar mijn mening kan een persoon maximaal drie buren hebben: links, rechts en achter. Of je woont in een flat."
} 
when he knew a customer very well, Seyit used a nickname in dialect to greet a friend or acquaintance, for instance: "Hé, wiekser!" meaning "Hey, wanker!" (Recordings, December 20, 2012).

Another pattern of greetings depended on the religious and ethnic background of the customer. Since the supermarket attracted many customers with a Muslim background, the Arabic greeting as-salamu alaykum (peace be upon you) was often used. This greeting was only used when staff members knew the customer or assessed him or her as being familiar with this greeting. The greeting was both shouted to familiar customers as well as uttered in a quieter and respectful manner when the customer was near or in front of the staff member. Customers were also the ones who first uttered this greeting. In any case, alaykum salam (and unto you peace) was uttered as a response by the person greeted. The more informal merhaba ('hello' in Turkish) and marhaba ('welcome' in Arabic) were used to greet customers with a Turkish or Moroccan background.

Another greeting was regularly uttered by Seyit and Deniz, but only to female customers with an assumed former Yugoslavian or East European background. When such a customer would walk in, both Seyit and Deniz would call her mevrouw (madame). That label is not that peculiar, yet their pronunciation of the word was. Where the Dutch variant of mevrouw is pronounced as [mə'vrau] with a schwa [ə] and a voiced labiodental fricative $[v]$, this particular use of mevrouw was pronounced as [mefraow] with an open e $[\varepsilon]$, an unvoiced labiodental fricative [f], and explicit emphasis on the first syllable. Apparently, Seyit and Deniz enregistered this particular pronunciation of mevrouw with coming from a former Yugoslavian or East European country, since they only used it when interacting with people they assumed had this background. This exemplifies that linguistic greeting routines were influenced, intersectionally, by ethnic background and gender (cf. Laver 1981).

One last example of a greeting relates to how the products sold at Dost Market seemed to influence the staff's greetings. During my first visit in the shop and later (Field notes, June 27, 2012 and December 5, 2012), customers that were perceived to come from Poland or Eastern Europe were greeted by Seyit, Ihsan or Deniz with the word kapusta, meaning 'cabbage' in Polish. When stocking shelves and checking prices of Polish products together with Seyit, I discovered that he probably must have learned this word through the preserved, canned Polish cabbage labeled kapusta (Field notes, February 22, 2013).

When parting, customers usually said hojje, which means 'bye' in dialect but is also widely used within (the northern and central part of) Limburg among people who do not use other dialect forms in their speech. Instead of hojje, Seyit usually said groetjes (greetings) when a customer left the store. Furthermore, I often heard him say the informal Moroccan Arabic beslemma (bye) to customers of assumed Moroccan descent. Thus, just as with greetings, goodbyes were usually adjusted to the language that the specific employee and customer had in common or to the background of the customer.

Wille et al. (2015: 9-13) have defined six multilingual practices that they found among cross-border workers in Luxembourg to deal with multilingual work situations, They presented the six practices in a continuum from minimal practice of multilingualism to maximal practice of multilingualism, as depicted in Figure 8.1 below): 


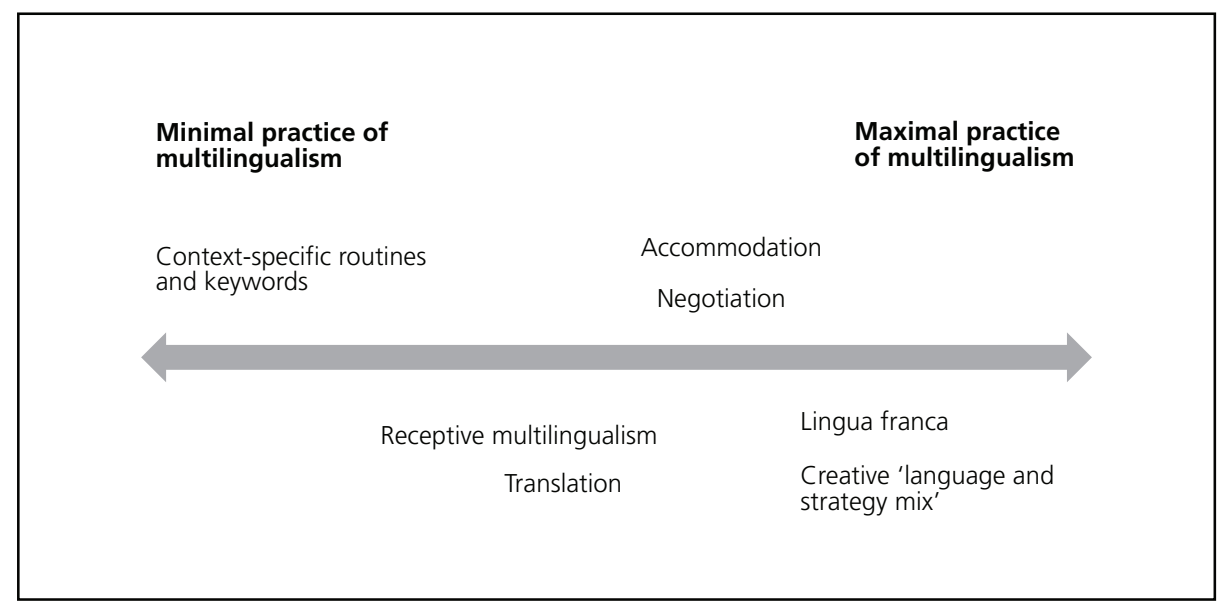

Figure 8.1: Continuum of multilingual practices (Wille et al. 2015: 10).

Greeting and parting routines, as found in Dost Market, could be described as context-specific routines that are "consolidated, repeatable procedures that are available to people as ready-made solutions to problems" (Lüger 1992: 18 in Welle et al. 2015: 10). These routines did not require any more extended language exchange: saying beslemma in Moroccan Arabic to a customer did not mean that Dost Market employees were able to have a full interaction exclusively in that language. Keywords thus sufficed to greet, get along with, and say goodbye to customers, as I will further illustrate below.

Compared with big chain supermarkets, Dost Market was rather small, which generally allowed for more personal contact (Van der Schans 2009: 57). At Dost Market, I found that greetings played an important role in binding customers to the store. According to Seyit, this could be seen as a selling point of smaller shops, such as Dost Market, since staff members at big chain supermarkets usually do not directly welcome or address customers without a reason (Interview with Seyit, May 5, 2015). Norms for politeness and efficient communication (Laver 1981; Rehbein and Fienemann 2004) thus influenced greeting and parting routines as much as marketing strategies that supported customer binding. In this way, language practices at Dost Market were commodified in providing symbolic added value to their products and services in order to make the store successful and to maximize profitability (cf. Duchêne and Heller 2012).

\section{The fun and friction of languaging}

When people of many different linguistic and cultural backgrounds meet, language is bound to be a fun topic to talk about and to learn from each other, as well as an issue that possibly presents difficulties or friction during interactions.

Almost every week, I witnessed how Seyit asked customers how they would call something in 'their' language. Often, he tried to remember these words or phrases and used them at the time of that particular customer's next visit, thereby actively expanding his 'languaging repertoire' (cf. Blommaert 2010). In general, the employees of Dost Market used Dutch, Turkish, and Kurdish to communicate with each other; this was heavily dependent on the person addressed, the subject, and the context. When customers were 
near and Seyit and Deniz wanted to say something that they did not want to share with customers, they would switch to either Turkish or Kurdish. Moreover, staff members used Dutch and forms from Moroccan Arabic to talk to intern Mustafa, who could not understand Turkish or Kurdish. With me, all staff members used Dutch, but they taught me particular forms, such as the Arabic nana (mint), kosbor (coriander), madnous (parsley) and Masha'Allah (an Islamic phrase to express praise, joy, and thankfulness) or the Surinamese barkie, that refers to a banknote of hundred euros. In this way, my own learning process resembled that of the staff members: through individual trajectories and experiences, we both learned particular words and expressions that were registered with a variety of languages that we subsequently could put into use in the supermarket (cf. Blommaert 2010; Jørgensen et al. 2011; Møller and Jørgensen 2009). One example of this languaging was Deniz's use of the Moroccan Arabic word mazyan in the previous chapter. When we talked about his knowledge of languages, I reminded him of this (Extract 2):

\section{Extract 2}

Deniz: I speak many languages. I have always worked in foreign stores. So I always want to know from all my customers how they call a particular product in their language.

Lotte: $\quad$ Last time I heard you saying mazyan.

Deniz: $\quad$ Oh! You remember that, haha! Yes, that is Moroccan for 'nice'. (...) Many people think I am Moroccan and start telling me whole stories in Arabic, but I cannot understand them. I only know pieces, but large pieces. Turkish and Kurdish are my first languages, for the rest I know pieces.

(Field notes August 3, 2012)

In order to deal with customers at the butchery that use different linguistic forms, Deniz thus engaged in the multilingual practice (cf. Welle et al. 2015) of learning specific keywords to deal with specific situations. Through his work as a butcher in - as he called them - "foreign stores," Deniz learned "large pieces" of his customers' languages. His expression "pieces of language," offers a fitting visualization of the process of languaging, in which people use linguistic forms that are at their disposal based on their individual life trajectory and experiences (Blommaert 2010; Jørgensen et al. 2011; Møller and Jørgensen 2009).

Moreover, Deniz's story also shows that languaging practices can be fraught with difficulties and confusion, as he was often mistaken as being a Moroccan who understood Arabic perfectly well, just because he knew a few words associated with that language. At Dost Market, I often observed similar moments of confusion in which it was hard for both employees and customers to decide in which language to start an interaction. For instance, my own appearance often caused confusion when customers approached me in Arabic or Turkish. At the end of my fieldwork, Demre started her internship at Dost Market. It was interesting to witness her dealing with the same sort of confusion I had experienced at the beginning of my fieldwork:

Demre just started her internship in the supermarket this week, and Seyit has to give her a lot of instruction on how to do things and how to do her job right. While I am having coffee in the back of the supermarket to warm up on a very cold winter day, Demre walks in. Before she closes the door to the small storage space, a customer in the shop asks for coriander, using the Moroccan Arabic kosbor to refer to it. "Yeah, sure," Demre says and walks into the refrigerator 
to fetch sheba, an herb better known as absinthe wormwood or green ginger. "No, coriander was what she wanted," I tell her when she comes out of the refrigerator. "What did she say?" "She said kosbor." "What is this then?" "This is sheba." "And which one does she want?" "Just coriander." "Ooh! Did she say coriander?" "No, she said kosbor." "Is that the same, too?" "Yes." Demre gives the bundle of coriander to the customer standing just outside the storage room. "What languages do you speak?" I ask her. "Just Turkish." "I think it is Moroccan." "Yeah, it must be, because I have never heard of it!" (Recordings, February 22, 2013) ${ }^{72}$

This example illustrates how most customers referred to the fresh bundles of coriander, parsley, and mint by using the names kosbor, madnous, and nana, respectively, without mentioning their Dutch names. All these names could be associated with Arabic, although nana and madnous are similar to the Turkish nane and maydanoz.

The customer assumed Demre would understand what kosbor was, which is why the customer did not consider using the Dutch name, koriander. In a way, I functioned as a kind of language mediator or translator (cf. Welle et al. 2015, see Figure 8.1) to enable a successful exchange of products between Demre and the customer. Moreover, similar to the customers' addressing me in Turkish or Arabic, this vignette reveals how discourses about embodied language practices influence daily interactions (cf. Alim et al. 2016; Bucholtz and Hall 2016): due to Demre's appearance, the customer assumed that Demre would be familiar with the Arabic name, kosbor.

Right after this conversation with Demre, Seyit walked into the storage room and must have heard my asking Demre about her language use, so he added (see Extract 3 below):

\section{Extract 3}

Seyit: $\quad$ Zij is Koerd, zij kan geen Koerdisch. Ik zei, warom leer je dat niet? Zij zo: wat heb ik aan die taal?

She is Kurdish, she does not know Kurdish. I said, why don't you learn it? She was like: what's the use of that language for me?

Lotte: $\quad$ En toen werd jij gek natuurlijk?

And that was when you went crazy, of course?

Seyit: $\quad$ Dat is, zeg maar, jij bent Nederlander, jij zeg, Nederlander, en, eh, je woont in Duitsland, zeg je: wat moet ik met Nederlands, je eigen taal!? Gek he? Klinkt gek he? That's, let's say, you are Dutch, you say, Dutch, and, uh, you live in Germany, you say: What's the use of Dutch. Your own language!? Crazy, right? Sounds crazy, right?

(Recordings, February 22, 2013)

Demre listened to Seyit's story but did not bother reacting to it. Seyit's consternation exemplifies how people, in their interactions with others, may root and safeguard

\footnotetext{
72 Lotte: "She said kosbor." Demre: "Wat is dit dan?" Lotte: "Dit is sheba." Demre: "En welke wilt zij?" Lotte: "Koriander gewoon." Demre: "Ooh, zei ze koriander?" Lotte: "Nee, ze zei kosbor." Demre: "Is dat hetzelfde ook?" Lotte: "Ja, welke taal spreek je zelf?" Demre: "Turks gewoon." Lotte: "Oké, ja dit is volgens mij Marokkaans." Demre: "Ja, volgens mij ook, want ik heb dit nog nooit gehoord."
} 
language to a place, thereby reproducing fixed connections between language, place, and body (Jaspers and Madsen 2016; Quist 2010). The mere fact that Demre had Kurdish roots was reason enough for Seyit to assume that she had learned or would at least be willing to learn Kurdish Kurmanci, since that must be her "own language," which he illustrated with the example of a Dutch person living in Germany. Moreover, the tactic of authority and illegitimation, as defined by Bucholtz and Hall $(2004,2005)$, also applied to Seyit's accusation of Demre, since he took up the authority to evaluate, judge and illegitimate Demre's behavior while, in a way, also denaturalizing her background as a Kurd.

While Demre's confusion about kosbor was resolved rather easily, sometimes miscommunication at Dost Market occurred when there was no common language to use, and customers used words or phrases that were incomprehensible to employees and bystanders. This was the case when a customer ordered meat in Hungarian at the butchery where Deniz, Ihsan, and his eldest brother were working (Recordings, October 16, 2012). The three men tried to find solutions to communicate with the woman by using German keywords, asking if there were bystanders able to translate, and by making up words that sounded East European. Deniz, on the other hand, was very impatient and used different linguistic forms to quickly boot the customer out of the butchery: "raus, raus, is goed, is klaar, jalla. Gein zeit, raus!" ("get out, get out, it's okay, it's over, go!"). In so doing, he engaged in what Walle et al. (2015) call creative 'language and strategy mix' by mixing German (raus), Dutch (is goed, is klaar), and Moroccan Arabic (jalla). Eventually, the customer wrote down the weight of the meat, which she pointed to, but she ultimately left the butchery unsatisfied because she could not explain to the men what she really meant. This miscommunication was a highly interesting encounter in which the men engaged in different linguistic strategies ranging from minimal to maximal practice of multilingualism (cf. Walle et al. 2015, see Figure 8.1) in order to find out what the customer wanted.73

In another case, Seyit and a customer (Recordings, October 2, 2012) engaged in a metalinguistic 'talk-about-talk' exchange to find out what the customer ('Cust' in transcript) wanted. I use the IPA symbols [s] and [z] in Extract 4 below to reflect the voiceless ('s'-sound) and voiced alveolar fricative ('z'-sound), respectively:

\section{Extract 4}

1 Cust ey vriend,

2 Seyit ja?

yes?

In Lines 3 and 4, as the customer struggled to produce a full sentence in Dutch, he turned to the French word 'poisson.'

3 Cust is dit, eh, (.) EY, die van eh, klein, die van, is this, uh, (.) EY, that from uh, little, that from,

4 Cust die poi[s]on (.) sardien. niks? that poi[s]on (.) sardine. nothing?

$\%$ ['poisson' is 'fish' in French]

\footnotetext{
${ }^{73}$ Due to space limits, I will leave it at this, but I envision analyzing this encounter in a future publication.
} 
In what follows, Seyit and the customer kept using Dutch to find out what the man was looking for.

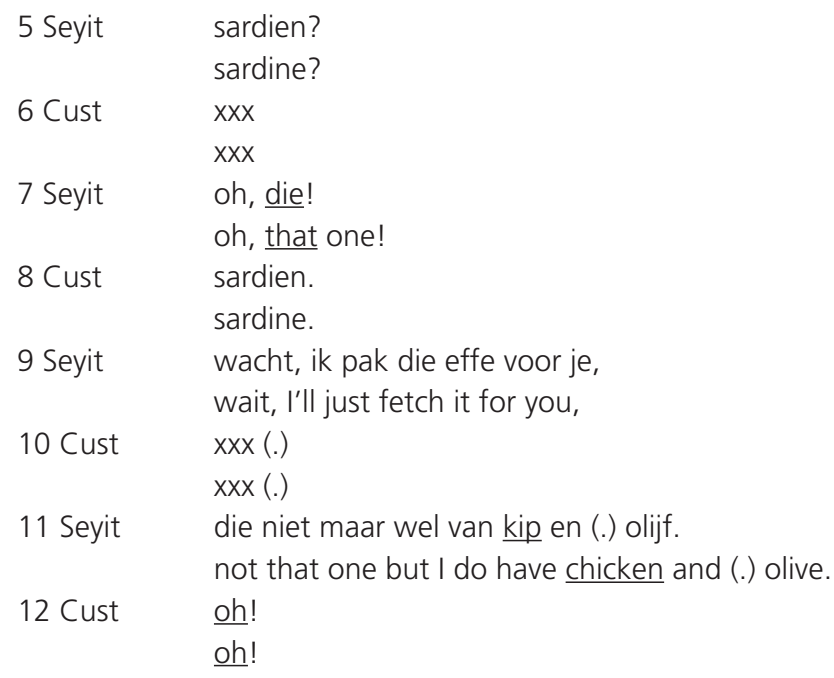

When Seyit wanted the man to follow him, he used Moroccan Arabic to make it clear that the man should accompany him:

13 Seyit shouf shouf goujja shouf! shouf shouf goujja shouf! \%['shouf shouf goujja shouf' is 'look look brother look!' in Moroccan Arabic]

14 Cust ja, shouf. yes, shouf. $\%$ ['shouf' is 'look' in Moroccan Arabic]

When Seyit checked with the man whether the product was big, the customer responded that this was not the case, which left Seyit puzzled:

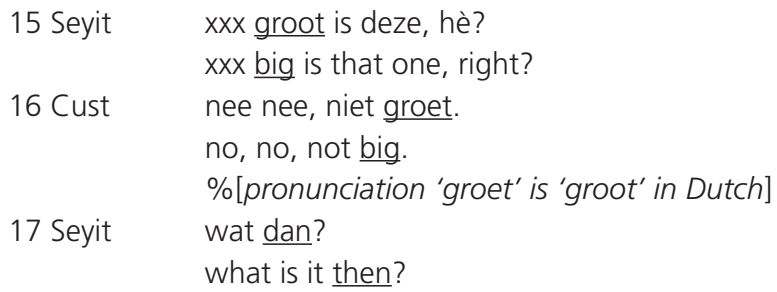

Then the customer inquired whether they could talk French to clear up the confusion, and Seyit affirmed that they could. I interpreted Seyit's tone in Line 19 (ja, eh, eh) as his wanting to say 'yes, of course, I do speak French,' primarily because he explicitly looked at me when claiming that he was able to speak French, thus indicating that he was highly aware of my research topic. More important, October 2, 2012 was the very first day that I switched on my recorder at Dost Market. I recognized that this made Seyit more aware of 
his own language practices. During this first day of recording, I felt that he tried to show off his linguistic skills and knowledge, of which ja, eh, eh seemed a perfect example.

18 Cust de poi[s]on, parlez-on francais? de poi[s]on, parlez-on francais? \%['de poisson, parlez-on francais?' is 'of fish, do we speak French?' in French]

19 Seyit ja, eh, eh, yes, uh, uh,

20 Cust $\quad x x x$ poi[s]on. $x x x$ poi[s]on.

21 Seyit poi[z]on, da's vis. poi[z]on, that's fish.

$\%[$ 'poison' is 'poison' in French]

22 Cust niet poi[z]on!

not poi[z]on!

23 Seyit poi[s]on, da's vis!

24 Cust $\quad x x x$ poi[s]on, that's fish!

$x X X$

Seyit then added English to the interaction to confirm once more that the man was looking for fish:

$\begin{array}{ll}25 \text { Seyit } & \text { fish yes, } \\ & \text { fish yes, } \\ & \% \text { [in English] } \\ & =y \text { Cust exact! Fish, } \\ & =y e a h \text { exact! Fish, } \\ & \% \text { [in English] }\end{array}$

27 Cust die die die bwa die kleine met met olijf. that that that bwa the little one with with olive.

Eventually, the men walked away while Seyit loudly said ajji in Moroccan Arabic, to which the customer responded with aruwah, the equivalent of ajji that is most common in the northeast parts of Morocco (the Rif region) ${ }^{74}$ :

$\%[$ They walk away, cash register bleeps (.5)]

$$
28 \text { Seyit } \quad \begin{aligned}
& \text { ajji ajji ajji ajji! } \\
& \text { ajji ajji ajji ajji! } \\
& \text { \%['ajji' is 'come' in Moroccan Arabic] }
\end{aligned}
$$

$\%[$ Lotte laughs]

29 Cust aruwah.

aruwah.

\%['aruwah' is 'come' in northeast Moroccan Rif Berber]

\footnotetext{
${ }^{74}$ Shokran bezaf (thank you so much), Adam Ettahiri and Mohammed Alaoui, for explaining to me the differences between ajji and aruwah.
} 
Extract 4 is a perfect example of what people do when 'one' specific common language is inadequate. Similar to what Franziskus and Gilles (2012) found in a Luxembourgish supermarket where staff and customers used different linguistic forms to cater to linguistic needs and to succeed in their work and grocery practices, Seyit and the customer engaged in languaging (Jørgensen et al. 2011; Møller \& Jørgensen 2009). It became clear what linguistic forms, enregistered with five different languages (Dutch, French, Moroccan Arabic, English, and Moroccan Rif Berber), both men had acquired during their lifetimes - which Seyit in particular seemed proud to show off during this interaction. In line with Walle et al. (2015), different multilingual practices were being used, including the use of specific routines and key words (shouf shouf goujja shouf and fish), accommodation and negotiation (parlez-on francais?), lingua franca (French), and creative 'language and strategy mix' by using different linguistic forms within one situated interaction. The interaction in Extract 4 illustrates the pragmatic function of languaging, in that it can be used as a strategy to find linguistic common ground and to overcome language barriers. Contestation is also part of this search for common ground; first, after the customer's request to speak French, Seyit's incorrect pronunciation of 'poi[z]on' (when he said 'poison' instead of 'fish') got corrected by the customer to 'poi[s]on' and, second, by adding aruwah to Seyit's ajji, the customer seemed to contest Seyit's assumption that Moroccan Arabic was a language that the customer affiliated with: instead, he affiliated with Moroccan Rif Berber, too.

Despite the fact that Seyit was highly aware of being recorded at that time, he seemed to be used to these kinds of interactions, where he and the customer mobilized different linguistic forms to come to a shared understanding. In so doing, "it is not so much about 'which' language but 'getting things done with language'" (Pennycook and Otsuji 2014a: 171). The interaction between Seyit and the customer emphasizes once more that ethnographic fieldwork and my deliberate focus on interactions within places, rather than on how particular 'communities' or groups of people speak, facilitates the examination of the spatial repertoires employed in a particular location (ibid: 168) and the ways that people employ language as a resource to draw linguistic forms from depending on the situation and location in which they find themselves.

Obviously, the specific context of this interaction (cf. Gumperz 1992) should be considered as well, since languaging was used, in this particular profitmaking supermarket setting, in order to make profit. Seyit used different linguistic forms in order to be able to cater to the customer's specific needs and to 'close the deal,' so to speak. It is here that I want to revisit the work of Duchêne and Heller (2012) on the pride and profit of language practices in late capitalist circumstances. I have already described how Dost Market was started up in a neighborhood where, up until then, no other shops were to be found that offered a similar product selection (Chapter 7, Section 7.3). In that sense, Dost Market could be seen as an example of late capitalism, in which they expanded the market by making a distinction in an area that lacked the offering of particular products. Dost Market was thus an added value to the diverse De Donderberg neighborhood. As Duchêne and Heller argue, language becomes more and more a technical skill in such late capitalist businesses in which profit and pride are closely connected. Extract 4 clearly exemplifies how the tropes of pride and profit were intertwined in people's motivations to learn and use particular linguistic forms. In order to make a profit and to arrive at an economic exchange of money and goods (the fish), Seyit and the customer made use of different linguistic forms associated with Dutch, French, Moroccan Arabic, English, and Moroccan 
Rif Berber. At the same time, pride played a role in this situated interaction, where Seyit clearly seemed to appeal to the customer's alleged pride in and affiliation with his Moroccan background by linguistically tailoring (cf. Duchêne and Heller 2012: 12) his speech to the customer with phrases like shouf goujja (look, brother) and ajji (come). This illustrates how language practices can transform pride into profit (cf. Del Percio and Duchêne 2012: 68), even though the customer made it clear he also related to Moroccan Rif Berber.

People may use linguistic forms depending on the context and communicative goals (cf. Jørgensen et al. 2011). As part of this languaging, people may also pretend they do not speak a language that well by ignoring grammatical norms. Deniz's returning question, "Lotte, jij nog steeds opnemen?" (see also Chapter 7), left out the auxiliary verb zijn (to be) and the progressive 'aan het (werkwoord)' construction ('at the (verb)' construction) and/or did not inflect the main verb opnemen (to record). The grammatically correct question would have been: "Lotte, ben jij mij nog steeds aan het opnemen?" or "Lotte, neem jij nog steeds op?" In the second part (jij moet betalen mij), Deniz was messing with the word order by misplacing the possessive mij (me) at the end of the sentence instead of in front of the infinitive betalen. The grammatical version would be "jij moet mij betalen." The first time Deniz talked like this, he was telling another customer that I was "investigating foreigners" (Recordings, November 22, 2012). Interpreting Deniz's recurring stylization of jij mij opnemen in the light of this quote about foreigners suggests that Deniz was simplifying his language use on purpose in order to ridicule and challenge existing stereotypes about foreigners. This is similar to what Jaspers (2011) found among youngsters in Antwerp, Belgium, who talked 'illegal' in order to teach others a lesson about Flemish society and to reproduce stereotypes about boys of Moroccan descent.

Although languaging can be great fun for those involved, it can also cause confusion and, in the worst case, miscommunication and friction. It is in these diverse environments like Dost Market that confusion and difficulties arise and make clear what ideas and assumptions prevail in people's minds about how to interact and talk. These instances of confusion shake up routines and force people to be creative in their interactions by improvising and finding solutions. This resembles Tsing's plea to appreciate 'friction' not as something that hinders development in globalization, but rather as an important condition that produces new arrangements of culture and power (2005: 5-6). In Tsing's words, frictions are "the awkward, unequal, unstable, and creative qualities of interconnection across difference" (ibid: 4). It is through these unsettling encounters that people are able to create new routines and connections. The languaging examples from Dost Market are examples of the fruitful and sometimes confusing outcomes of friction.

\section{The use of dialect at Dost Market}

Customers as well as staff members of Dost Market also used dialect to interact. An example of this was when elderly women, who usually visited the store on weekday mornings, would be greeted with ha sjat, dialect for 'hey, darling'; this greeting was reserved solely for them (Field notes, September 27, 2012). Of all the employees, Seyit was the one who used dialect the most. He did so primarily with those customers he knew could speak and understand dialect. Seyit used dialect in serious interactions but also in what Hymes called a humorous 'key' (Hymes 2001 [1974]: 57). The humorous key was mainly used when talking dialect in fun small talk with customers or when using dialect with other staff members. I observed that when Seyit used dialect with other employees, 
he often did so in a humorous manner by imitating customers (Recordings, December 20, 2012) or using shibboleths; for example, det guf 't toch neet meaning 'there is no use' (Recordings, September 20, 2012). I evaluated his pronunciation of dialect as 'authentic' and, judging from his continual dialect interactions with regular customers, my conclusion is that customers did so, too. When I asked Seyit what languages he was able to speak, he averred that he spoke six languages: Kurdish Kurmanci, Turkish, Dutch, English, French, and German (Recordings, October 8, 2012; Interview, February 7, 2014). In addition to these languages, he had also learned some Moroccan Arabic because of his best friend, who came from a Moroccan background. My data show that Seyit had assembled a considerable linguistic repertoire over the years that included linguistic forms that are indeed associated with the different languages he claimed to speak. This is illustrated by Seyit's enumeration, which leaves out his use of dialect. This may be because he did not regard dialect as 'a language,' which became clear when we were having a coffee break in the storage room, and I started to explain tonal similarities between Chinese and Limburgian dialect (Recordings, October 18, 2012). Seyit thought this was complete nonsense, as reflected in Extract $5 a b$ below. In the Dutch lines in Extract $5 a b$ below, Dutch is in italics and dialect is in plain; in the English lines dialect is in italics and translated in parentheses afterwards:

\section{Extract 5a}

Seyit:

Limburgs, das toch geen taal, man! Is gewoon de rotste taal die ik ken! Ja, man. Wie geit 't, ja good, mit dich? Jao, jao. Slaat nergens op!

Limburgian, that's not a language, man! It's simply the most rotten lan guage I know! Yes, man. Wie geit 't, ja good, mit dich? Jao, jao. (How are you? Yes, good, and you? Yes, yes.) It makes no sense!

(Recordings, October 18, 2012)

Nevertheless, he added in Dutch, he had learned to speak dialect because of two reasons: first, by living in Roermond, a place where a lot of dialect is used and, second, through school, the street, and the soccer club.

\section{Extract $5 b$}

Seyit: Weet je hoe ik dat heb geleerd? Omdat ik... Ten eerste, we wonen in Roermond, dus dat sowieso, daar wordt veel Limburgs gesproken. Ten tweede... Op school, op straat, voetbalvereniging.

You know how I learned? Because I... First, we live in Roermond, that in any case, a lot of Limburgian is spoken there. Second... At school, on the street, soccer club. (Recordings, October 18, 2012)

Later, when returning to the subject of dialect use, it became clear to me that Seyit did not feel comfortable speaking dialect. Again, in the Dutch lines in Extract 6 below, Dutch is in italics and dialect is in plain; in the English lines dialect is in italics and translated in parentheses afterwards: 

Extract 6
Seyit:
Spreek je dat goed?
Do you speak it well?
Lotte:
Dialect? Ja, het gaat, ik denk net zoals jij.
Dialect? Yes, so-so, I think just like you.
Seyit:
Geit 't waal?
Geit 't waal? (So-so?)
Lotte: Jao, 't geit. Jij spreekt het ook goed, toch?
Jao, 't geit. (Yes, so-so.) You speak it well too, right?
Seyit: $\quad$ Ah, 't geit, neet zo, maar... Weet je wat het is, ik voel me d'r niet fijn bij. Ik probeer dat, maar ik voel me d'r niet fijn bij, als ik plat praat. Klinkt heel raar, maar is echt zo. Klinkt zo blöd, serieus. Zie je een Turk die dinge, plat praten. Ey sies, wie geit 't? Ja, good. Dat is blöd, weet je wel? Maar af en toe doe ik dat gewoon om te lachen.
Oh, 't geit, neet zo (so-so, not really), but... You know what it is; I don't feel comfortable with it. I try it, but I don't feel comfortable, when I speak plat. Sounds very weird, but that is how it is. Sounds so blöd (stupid), seriously! You see a Turk who, what's it, speaking plat. Ey sies, wie geit 't? Ja, good. (Hey, dude, how are you? Yes, fine.) That's blöd (stupid), you know? But sometimes I do it just for a laugh.
(Recordings, November 16, 2012)

Seyit's explanation that he, as a Turk, felt stupid when using dialect is in line with Jaspers' study $(2004,2011)$ of youngsters with a Moroccan background in Antwerp. Jaspers found that these youngsters used dialect to play around and to construct themselves as inauthentic. In doing so, they ridiculed the use of dialect altogether. Jaspers concluded that the youngsters did not regard Antwerps as their own variety or as a variety they genuinely wanted to use (Jaspers 2004: 138). Yet the fact that these youngsters related to the dialect to this extent showed that they were more integrated into Flemish society than they would at first claim (Jaspers 2011: 296). Similarly, Seyit's use of the word blöd, which can be enregistered as both dialect and German, would suggest that, while he felt uncomfortable using dialect, he did simultaneously relate to dialect, albeit in ambiguous ways and, as he claimed, to have a laugh.

It is here where this study of Dost Market adds new insights about languaging practices, since my findings exemplify and support the idea that these practices are not only found in central and urbanized areas (cf. Wang et al. 2013). From my fieldwork at the supermarket, it became clear that, on the one hand, a mix of both 'classical' European languages (Dutch, English, French, German) and Turkish, Arabic, and dialect could be found at Dost Market, albeit in ambiguous, humorous ways, as Seyit's quote seems to suggest. As a result, a place was produced where both staff members and customers felt comfortable using whatever linguistic form they saw fit in a particular communicative setting to interact with each other, to order, sell, and buy particular products, and to negotiate, construct, and guess about potentially shared feelings of foreignness. The next section describes what linguistic forms were used within the store's linguistic and semiotic landscape of advertisements, price tags, and notices. 


\subsection{Displaying spatial repertoires in the linguistic landscape of Dost Market}

In order to study how people engage in place-making processes, Cresswell (1996: 16) encourages observing how people 'read' places and act in ways that conform with or against these interpretations of a particular place. The linguistic landscape paradigm serves as a suitable tool to examine this (see also Chapter 4, Section 4.2). Where linguistic landscaping originally focused on shop windows (Blommaert 2013) and street signs (Landry and Bourhis 1997), I decided to focus on Dost Market's advertisements, price tags, and notices to understand which linguistic forms were produced as appropriate and deviant in order to give meaning to this space (cf. Cresswell 1996), thereby yielding insights into linguistic place-making processes from an analytical perspective.

\section{Advertisements and price tags at Dost Market}

Advertisements in the supermarket were mostly displayed in Dutch. However, sometimes advertisements and handwritten price tags were also written in Turkish. This was the case with a handwritten advertisement that was displayed in the butchery, which stated verse rundergehakt ${ }^{75}$ and underneath klyma, signifying freshly ground beef in both Dutch and Turkish (Field notes, December 10, 2012). This advertisement hung amongst other advertisements that were written in only Dutch. Another example was a handwritten sign that advertised the Turkish delight sweets located in the fresh pastry rack: Turks fruit, verschillende soorten: lokum çeşitleri. The Dutch part can be translated as 'Turkish delight, different types,' while the Turkish part means 'different delights' (Field notes, December 20, 2012). The presence of these (mostly handwritten) Turkish signs indicates that Dost Market - a partly Turkish name itself - was a shop where Turkish forms could be understood and used by both staff members and customers. Besides my own appearance, this would explain why some customers did not hesitate to immediately start talking in Turkish to me.

Apart from advertising products, price tags and the linguistic forms used on these tags next to the price revealed important information. In the fruit and vegetable section, handwritten sheets of paper were used to indicate the name and price of a product. Alternatively, laminated paper was also sometimes used; this only indicated the name of the product, allowing staff to change the price with a white-board marker according to the auction price of that day. One example of a handwritten price tag in the vegetable section was biber per zak. The Turkish word biber is used to refer to 'bell pepper,' while the Dutch words per zak mean 'per bag' (Field notes, December 12, 2012). As was the case with kıyma (ground beef) at the butchery, it was assumed by the maker of this price tag that some customers would understand what was written while others could find out for themselves what was inside the bag. Initially, shelved products had handwritten price tags. These labels were put behind a plastic price tag holder that was attached to the shelves. However, during the fieldwork period, Seyit was in the process of turning the handwritten tags into printed ones. I asked him how he decided what to put on them:

\footnotetext{
${ }^{75}$ From the literature, it is known that bilingual speakers of Dutch may struggle with grammatical neuter gender in Dutch (Cornips 2008). The attributive adjective in Dutch shows the flection -e morpheme but only in the definite condition for both common and neuter gender. Rundergehakt is neuter. In the definite context, het verse rundergehakt with the flection -e would have been correct. Yet in the indefinite context, the adjective should not get an -e morpheme with a neuter noun: vers rundergehakt.
} 


\section{Extract 7}

Seyit:

Meestal, eh, soms heb ik wat op de factuur stond en soms heb ik ook wat op de dinges staat, ja, snap je? Kijk, bijvoorbeeld, hier staat, İnegöl köfte, maar die moet nog uitgeprint worden, İnegöl köfte, moet İnegöl köfte d'rop. Ik kan er niet veel meer maken. Als ze zeggen wat is İnegöl? Dat is een plaats in Turkije.

(...) Bijvoorbeeld hier, Essafir thee. Mensen wetel, Marokkaanse mensen die dit ge bruiken weten wat dat is. ledereen die wat dit koopt, die weet precies waarvoor hij koopt, of zij koopt.

Often, uh, sometimes I take what was on the invoice, but sometimes I also take what is on that thing [product], yes, you see? Look, for example, here it says Inegöl köfte, but that one still needs to be printed out. Inegöl köfte, then it should say Inegöl köfte. I cannot make more of it. If they say, what is Inegöl? That is a place in Turkey. (...) For example, here, Essafir tea. People kno/, Moroccan people who use this, they know exactly what it is. Everyone who buys this knows exactly what he buys it for, or she buys.

(Recordings, December 20, 2012)

In this quote, Seyit exemplified his working method by referring to Inegöl köfte, a spice mix for minced meat. ${ }^{76}$ Seyit claimed he could not translate Inegöl, since it was a place in Turkey that customers either knew or did not. Yet he did not opt to describe it as 'herb mix' on the printed price tag. When I looked at other products, I observed that many products with Turkish names and stickers were not translated on price tags. Moreover, the quote above shows that Seyit seemed to expect that only certain customers would buy particular products, such as 'Moroccan people' buying Essafir tea (Figure 8.2).

Figure 8.2: Essafir tea at Dost Market (photo taken by the author, May 28, 2017).

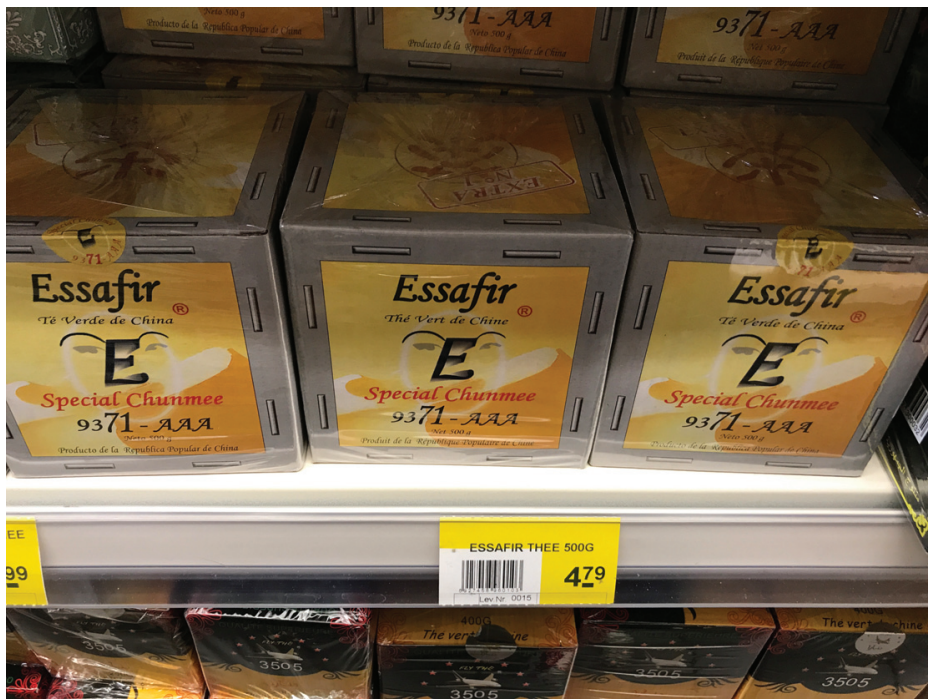

\footnotetext{
${ }^{76}$ At the time of writing, the product had disappeared from Dost Market's product assortment, so I was unable to take a photo of the product and the price tag.
} 
The jars of preserved Polish food strengthened this idea. The product sticker as well as the price tag displayed only the Polish names: marchew z groszkiem i kukurydza, kapusta, buraczki plastry, and rubin sałatka being examples of this. Customers who did not understand Polish thus had to guess what was inside the jar or take a closer look through the glass (see Figure 8.3 for an example). ${ }^{77}$

Figure 8.3: Sałatka z zielonych pomidorów at Dost Market (photo taken by the author, May 28, 2017).

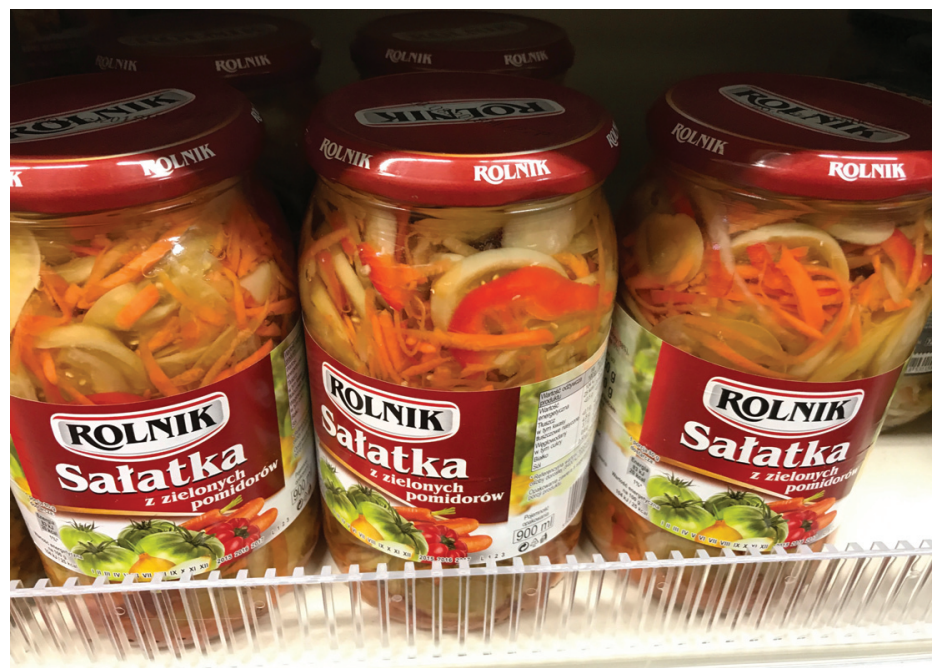

Judging from just a few examples of the products available at Dost Market, it can be concluded that this shop could not be regarded as an ethnic shop where the product assortment represented only one ethnic group. Yet there were particular sections of the shop that could only be understood at first glance by particular segments of customers, like the Polish products and the sections noted by Seyit on his diagram (see Figure 7.7 of Chapter 7). In my view, this was part of a place-making process, in that it attached linguistic forms to a particular space that, as a result, defined which customers (for example, those with a Turkish background) were perceived as in place and out of place in that section. Defining a section of the store on the basis of the customers' background reflects how space and place were used to structure a normative landscape: "the way in which ideas about what is right, just, and appropriate are transmitted through space and place" (Cresswell 1996: 8).

As with the motivation to address particular customers in 'their' alleged language (such as saying kapusta to alleged East European customers and using Moroccan Arabic to the customer in Extract 4), the intertwined tropes of pride and profit (Duchêne and Heller 2012) largely motivated the decision to display the original name of a product or to write the name down in the assumed first language of customers of a particular background, such as klyma, biber, Inegöl köfte, and marchew z groszkiem i kukurydzą. Through responding to and making use of people's (assumed) linguistic and cultural affiliations

\footnotetext{
${ }^{77}$ At the time of writing and taking the photo of Figure 8.3, a new Polish shop had opened in De Donderberg shopping mall. Consequently, most Polish products disappeared from Dost Market. Sałatka z zielonych pomidorów was the only Polish product left. Unfortunately, I did not take photos of the products at the time of fieldwork.
} 
and feelings of belonging, I suggest that these (handwritten) advertisements and price tags were aimed at selling products more easily to customers of a particular background, thereby transforming pride into profit (cf. Duchêne and Heller 2012).

\section{Notices at Dost Market}

Besides the advertisements and price tags, I observed notices, written in various languages, at Dost Market that informed customers about the shop. These notices were mainly displayed at the entrance/exit and cash desk area. One notice stated in Dutch that the store made use of surveillance cameras, while another notice requested customers, again in Dutch, to leave their bags at the cash desk while doing their shopping, probably to avoid confusion about what products were purchased where (Field notes, December 20, 2012). Not long after the renovation of Dost Market, I saw a poster that had been put up on the store's new exit door (Figure 8.4).

Figure 8.4: Poster at the exit of Dost Market (photo taken by the author, March 1, 2014).

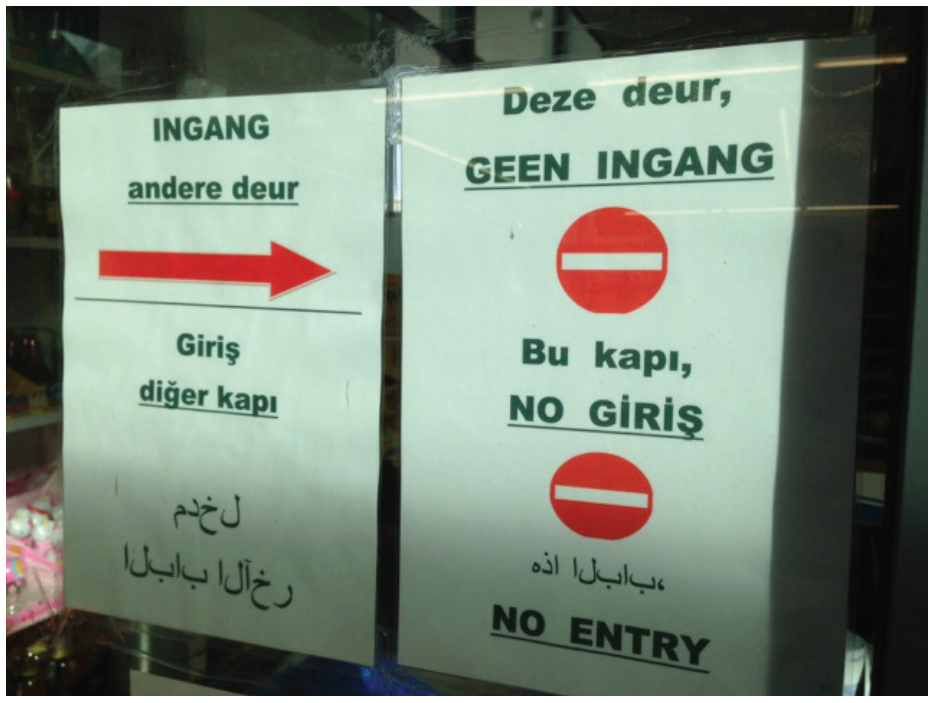

When I asked Seyit about the poster, he explained that a customer had been so annoyed about the many customers that used the new exit door as an entrance that he had taken the initiative to design a poster for them to put up (Field notes, May 5, 2015). Seyit immediately recognized the mistakes in the poster. The customer had probably used a translation tool such as Google Translate to deliver the message. Seyit explained to me that the Turkish sentence for 'no entry' was partly correct, but that no in no giriş was just the English word 'no' (Field notes, May 5, 2015). Additionally, the Arabic part was written in the wrong left-to-right direction, thereby making it quite unreadable to people actually used to reading Arabic, as described to me by Narges Ghandchi (Figure 8.5): ${ }^{78}$

\footnotetext{
78 These data are thanks to Narges' attentiveness and knowledge of Arabic. I was lucky to have her attend my data session at the University of Copenhagen in April 2015.
} 


\begin{tabular}{|c|c|c|}
\hline $\begin{array}{l}\text { Separate letters on the left page } \\
\text { of the picture }\end{array}$ & Correct writing direction & Gloss \\
\hline إل & 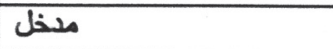 & Entry other \\
\hline رخآل بالبلا & الباب الأخر & Next door \\
\hline $\begin{array}{l}\text { Separate letters on the right } \\
\text { page of the picture }\end{array}$ & Correct writing direction & Gloss \\
\hline 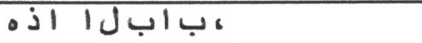 & هذا البابب ، & The door this \\
\hline
\end{tabular}

Figure 8.5: Explanation of Arabic on the door sign at Dost Market.

What becomes clear from the translation is that, in the sign on the right in Figure 8.4, the words 'no entrance' were forgotten in the Arabic version of the sign. Despite these mistakes, Seyit decided to put up the poster at the exit door. When customers informed him that there were mistakes and that the Arabic part was unreadable, Seyit explained he did not want to insult the customer who had designed the poster.

From a linguistic landscape point of view, the poster is interesting, since it shows that this particular customer perceived Dost Market as a place where people related to, used and understood Dutch, Turkish, Arabic, and English. The choice and order of the language display is also interesting: Dutch is used first, followed by Turkish and Arabic. English is only used on the second page, simply to state that this is not the entry. In comparison to the linguistic landscapes of other shops in the shopping mall, it is striking to see that Dost Market used different linguistic forms than the other shops, which generally only displayed Dutch and, occasionally, dialect (mainly during the carnival season). Moreover, this specific hierarchy of languages (Dutch, Turkish, Arabic, and English) was not found in the city center of Roermond, where touristic guideposts display Dutch, English, German, French, and Chinese, in that specific order, mainly to accommodate tourists visiting the city (see Figure 1.6 of Chapter 1). The language hierarchy on the Dost Market notice (Figure 8.4) and the language hierarchy of the city center's guidepost show how linguistic landscapes may differ, even within the confines of one municipality, and that the city center was experienced and perceived as a different sort of place than Dost Market in De Donderberg neighborhood. Moreover, the touristic guidepost in the city center and the handmade sign at Dost Market suggest center-periphery power differences between the two places: in the city center, the municipal government was willing to invest time and money in producing an expensive touristic guidepost, whereas at Dost Market, located in the peripheral De Donderberg neighborhood, a customer voluntarily chose to make a paper sign.

\section{Calendar notices at Dost Market}

Another type of notice at Dost Market notified customers about the store's opening hours during the holidays. During fieldwork, the supermarket only closed on Christmas and

\footnotetext{
${ }^{79}$ The opening hours of the shopping mall changed after fieldwork: it is now also open on Christmas and New Year's Day. This is in line with the trend that big chain supermarkets in the Netherlands - not just in the Randstad area - are increasingly opening their doors on holidays.
} 
New Year's Day, since the shopping mall as a whole was closed during these holidays. ${ }^{79}$ Throughout the carnival days, the supermarket was open as usual, whereas other stores in the shopping mall (smaller shops) were either closed or adjusted the hours they were open (the big chain supermarkets). When I worked at the supermarket, Dost Market was opened regularly on Islamic holidays. Yet when visiting the store in 2016 to pick up groceries, I found out that the store had closed for Eid-al-Fitr, the feast that follows upon the Ramadan month of fasting. The following printed message had been put up next to the cash desk:

\section{DUYURU}

Gelecek Sali günü 05-07-2016, bayram nedeniyle kapaliyiz. Anlayisiniz icin tesekkür ederiz. Dost Market adina herkeze iyi baryamlar dileriz. Carsamba 06-072016 günü kapilarimiz yine normal saatte acilicaktir, 08.00 den itibaren.

Aanstaande dinsdag, 05-07-2016, zijn we in verband met het Ramadanfeest of te wel suikerfeest de hele dag gesloten. We bedanken u voor u begrip. We wensen namens Dost Market iedereen een fijn ramadanfeest. Woensdag 06-07-2016 zijn wij gewoon weer geopend vanaf 08.00uur.

In my translation:

ANNOUNCEMENT

Next Tuesday, 05-07-2016, we are closed due to the Ramadan feast or 'suikerfeest' for the whole day. We thank you for you [instead of 'your'] understanding. On behalf of Dost Market we wish everyone a nice Ramadan feast. Wednesday 06-072016 we open regularly from $08.00 \mathrm{~h}$ onwards.

This notice caught my attention, since it was delivered in two languages, first in Turkish and then in Dutch. What stood out was that there was no Dutch equivalent of the word DUYURU, meaning 'announcement,' so the announcement could easily be overlooked by those customers who did not understand Turkish. Besides this, the Dutch we bedanken $u$ voor $u$ begrip (we thank you for you understanding) used the pronoun $u$ twice, the former one was a personal pronoun, while the latter was the possessive pronoun which should have been written as uw (your). Moreover, Arabic-speaking customers did not have their 'own' translation of the message, but this could be due to the fact that most Arabicspeaking Muslims celebrated the Ramadan feast of 2016 one day later, on July 6. Within the Netherlands, Muslims generally follow two traditions in deciding the date of their feasts. Most Turkish people rely on the Turkish Presidency of Religious Affairs (Diyanet issleri Başkan/ığı), which calculates the dates of important Islamic feasts, such as the beginning and end of the month of Ramadan and the date of the Feast of Sacrifice. Other Muslims depend on the moon phases as they are seen in Mecca. The beginning of Ramadan, for example, is marked when the New Moon rises in Mecca. In 2012, Diyanet calculated that the Feast of Sacrifice would take place on October 25. On that day, a split was visible between people in the supermarket who were celebrating the Feast of Sacrifice on that day and those who were waiting for Mecca to announce the Feast. While many customers were all dressed up, perfumed, and in a celebratory mood, Seyit and Deniz (who followed Mecca) tried to convince them that they were wrong. For the Mecca-followers, the Feast of Sacrifice was ultimately announced the next day, on October 26, 2012. 
These observations suggest that some feasts and holidays were far more visible in the linguistic landscape of Dost Market, while others, such as carnival, were not addressed by making explicit notices. The same held true for the weekly rhythm of Dost Market. It was remarkable that the shop's busiest days were not just Saturdays, as with most supermarkets and stores, but also Friday afternoons, after the Friday prayer (Salat al-djuma) at the mosque, after which many customers came to the shop to buy meat for the evening and coming weekend.

\section{Semiotic landscape}

The display of linguistic forms at Dost Market, associated with more languages than just Dutch, co-constructed a store where customers were addressed in various ways to facilitate their shopping and their feelings of being welcome in the shop. In order to enlarge the scope of the linguistic landscape paradigm, Jaworski and Thurlow (2010) proposed the term 'semiotic landscape.' This approach goes beyond analyzing the display of linguistic forms by including the study of images in spaces. From this viewpoint, the way that Dost Market was decorated is worth considering. Compared to other stores in the shopping mall, the supermarket was not very active in putting up seasonal or holiday decorations. For example, Dost Market did not participate in the shopping mall's carnival decorations; where chain supermarket Jan Linders and other shops all decorated their entrances with red-yellow-green balloons, carnival colors, Dost Market's entrance remained the same. ${ }^{80}$ The only visible decoration in the supermarket was a cardboard shelf with products for the Islamic fasting month, although it is doubtful whether this shelf was placed especially for Ramadan, since it was placed long before Ramadan started and stayed there long after. Moreover, when Islamic holidays were coming up, the supermarket would sell more freshly baked pastries and cookies, such as baklava (a Turkish puff pastry with nuts and honey) and chebbakia (a Moroccan cookie with honey and sesame seeds). Also, in terms of special advertisements for holidays, there were no explicit sale advertisements to be found around either Christian or Islamic holidays. Nevertheless, many customers were aware that they could reserve turkeys in the days before Christmas. Similarly, when Islamic holidays were coming up, the butchery would be much busier than during other periods of the year. Thus, when taking into account the semiotic landscape of Dost Market and the use of images and - I would add in this case - the display of seasonal products, it becomes clear that Islamic feasts and holidays were highlighted and prioritized over other feasts celebrated in the Netherlands and Limburg, such as Sinterklaas, carnival or Christmas.

\section{Conclusion}

My experiences and observations at Dost Market enabled me to coin the concept of foreignness, which describes a feeling of belonging existing between two or more persons based on their perceived otherness, exclusion or unbelonging in a certain place. I have explained what societal developments foster the existence of these feelings of foreignness and how people at Dost Market tried to establish shared foreignness in practice. My

${ }^{80}$ Observed on 'carnival Saturday', March 1, 2014. 
interactions with Yassine and Deniz served as examples of guessing games seeking to find reasons to bond through a sense of being persons generally considered as 'the others' within the Netherlands due to background and descent. Despite the fact that I developed my understanding of foreignness on the basis of Dost Market, I want to emphasize that foreignness has no particular (ethnic, gender, religious, etc.) bias and can be experienced by anyone at any particular place and time, even by people perceived as 'natives' from a national perspective, such as David and Zeegert, who felt out of place in Limburg as 'Hollanders,' and Maasniel's De Katers carnival association, that still felt out of place within the city of Roermond.

Furthermore, I have shown in this chapter how languaging practices produced Dost Market as a place where linguistic diversity associated with local, regional, national, and global levels was not amiss within interactions. The use of linguistic diversity, both in interactions as well as on display in the shop, was part of place-making processes and rendered the place its own character and dynamics. Different linguistic forms could be used alongside each other: Dutch, dialect, Moroccan Arabic, Moroccan (Rif) Berber, French, English, Kurdish Kurmanci, and Turkish. As a result, this chapter provided evidence for the claim made by De Lima (2012) and Wang et al. (2013) that linguistic diversity is not only found in the urbanized centers, but also in peripheries such as Limburg within the Netherlands. I have argued that place-making processes made Dost Market into a meaningful place where particular daily routines and language practices, including languaging, were perceived as being acceptable and normal (cf. Cresswell 1996). I have pointed out how the particular practices at Dost Market produced a place that was regarded as a 'foreign' supermarket, where customers assumed they could bargain about prices or get rid of small change (see Chapter 9). The use of linguistic forms associated with a variety of languages, in interactions and on display in the shop, transformed Dost Market into a place that left space for customers and staff members to use whatever linguistic form they saw fit in a particular context and to negotiate, reproduce, and construct shared feelings of foreignness or belonging through unbelonging.

Where this chapter has specifically focused on place-making practices and processes, the next chapter's analysis of a situated interaction between Seyit and a customer will specifically exemplify how people employ linguistic forms to claim, legitimize, and challenge politics of (un)belonging. Moreover, the chapter will clearly illustrate how people construct, negotiate, and use foreignness in daily interactions. 


\section{Chapter 9}

\section{"Because here we live in the Netherlands": Constructing foreign- ness and politics of (un)belonging in a situated interaction at Dost Market}

\section{Introduction ${ }^{81}$}

The previous research cases aimed at giving insight into the ways that people, by engaging in language practices with others, give meaning to the everyday places they inhabit. In so doing, previous chapters exemplified how politics of (un)belonging are negotiated among people in interactions within particular places. The visit of the mythical figure of Sinterklaas at the staged carnival event at De Katers carnival association (Chapter 5) made it clear that Sinterklaas was initially perceived as being out of place, but that the figure, as well as the celebration of Sinterklaas as a whole, was incorporated into the carnival event as being in place by means of carnivalesque practices that turned norms and linguistic and cultural expectations upside down. The research case of David and Zeegert (Chapter 6) suggested that feelings of place-belongingness (Antonsich 2010: 645) can be quite ambiguous, since people can feel both in as well as out of place within a particular location. My interaction with the two men, who were both born outside the province of Limburg, showed how they made efforts to make their place within Roermond and Limburg and how they struggled with feeling in place in the psychical place of Roermond but out of place among its people. Moreover, their case exemplified how they felt a sense of belonging together precisely because of their alleged unbelonging within Limburg, since they were both "no Limburgers." Based on my empirical findings at Dost Market, I have coined the term foreignness to refer to these feelings of belonging through unbelonging (Chapter 8).

This chapter's case study introduces a female customer whose small coins were refused by the cashier, Sevim. When Seyit joined the discussion with the customer, the topic of the interaction quickly changed from small coins to, as I will show, questions of belonging. I will specifically focus on how people, in their interactions, give meaning to places while at the same time negotiating ideas about who legitimately belongs and who illegitimately unbelongs. This chapter examines the consequences of the customer's correction of Seyit's coin-refusing practices with the statement "because here we live in the Netherlands," implying that 'here, we do things differently.' By using the tactics of intersubjectivity (Bucholtz and Hall 2004, 2005), my analysis of the situated interaction between Seyit and the customer will examine how people employ linguistic forms to claim, legitimize, justify, and challenge politics of (un)belonging. Moreover, the chapter will make it clear how people construct, negotiate, and use foreignness in daily interactions and how foreignness may be associated with certain language practices and ideological norms. I claim that feelings of foreignness are never exclusive and may exist alongside other feel-

\footnotetext{
${ }^{81}$ For this chapter, I use parts of my paper published in the journal Applied Linguistics Review (Thissen 2015). Special thanks go to the editors of Applied Linguistics Review for letting me use the paper in my dissertation. In the paper, I decided to use fictional names for the staff members of Dost Market.
} 
ings of belonging and unbelonging. Subsequently, it becomes clear that the question of 'who belongs' can be important to anyone, including people who, at first sight, might be considered to share a similar so-called migration background.

A grounded focus on locations (Chapter 2) enabled me to examine how issues of belonging came to the fore in daily interactions and situations at Dost Market. Moreover, this focus enabled me to go beyond the labeling of 'a' particular ethnic majority or minority, by departing from a particular location. This grounded focus on locations is needed in the context of globalization, where the use of language as a resource to draw linguistic forms from makes fixed categories of 'language,' 'ethnicity,' and 'backgrounds' redundant (cf. Jaspers 2008; Quist 2010). Statements like 'the Dutch speak Dutch and share a Dutch culture' simplify reality in unnatural ways, because the daily reality is far more complex and cross-connected. We should thus ask ourselves how to disconnect the fixed bond between language, place, and belonging in order to recognize contemporary empirical realities. To that end, I took Dost Market as the starting point for my research. Instead of assigning top-down categories to my research participants, I carefully investigated which particular language and cultural practices, ideologies, and categories were deemed salient by staff and customers within that place; that is, I took into account the specific groups of 'us' and 'them' and categorizations that were salient to people within Dost Market. In other words, this chapter considers actual daily manifestations, legitimations, and challenges of feelings of (un) belonging. This chapter elucidates how co-owner Seyit and a customer legitimized their own feelings of (un)belonging, while at the same time challenging those of others. The following situated interaction taken from Dost Market demonstrates how a seemingly petty discussion about one and two eurocents quickly devolved into a dispute about politics of (un)belonging.

\subsection{From a quarrel about small coins to politics of (un)belonging}

It is important to emphasize that Dost Market was regarded by both staff members and customers as a 'different' place in comparison with other shops located in the shopping mall of De Donderberg neighborhood. This was already observed by Seyit in Chapter 8 when he claimed:

The annoying thing about a buitenlandse winkel (foreign shop) is that people always try to get a discount. They would not do that at Plus or Jan Linders, because there they display the fixed price of the product. I do that too, nevertheless, people suddenly say about something that costs 1,25 euro: "Give me that for 1 euro." (Field notes, July 9, 2012)

Seyit's quote above shows that customers perceived Dost Market as a different sort of a place, where it was possible to bargain. And, indeed, this chapter deals with a situated interaction in which a female customer tried to get rid of small coins of one and two eurocents. If people were to go to a bank to exchange these small coins, they would be required to pay for this service, which makes paying with these coins a cheaper option. However, most shops in the Netherlands refuse to accept these coins due to the extra costs and round up sums automatically. The fact that the customer came to this particular supermarket suggests that she perceived Dost Market as a place where she could try to get rid of her small change for free. She probably knew that the big supermarkets would 
certainly refuse these coins and hoped for better luck at Dost Market. The interaction below shows what happened when it turned out that this 'different' supermarket rejected these coins as well. By using the statement "because here we live in the Netherlands" as an explanation for why Seyit should accept the small coins, the customer explicitly challenged Seyit's feelings of being in place within and belonging to the Netherlands, since she seemed to imply that he lacked the knowledge of how things usually go here. In what followed, an outraged Seyit defended and claimed legitimate belonging at different levels while illegitimizing the customer's feelings of belonging, even long after the customer had left the store. I argue that this exemplifies how feelings of place-belongingness become intertwined with politics of (un)belonging (cf. Antonsich 2010; Christensen 2009; YuvalDavis 2006). The use of concepts such as feelings and politics of (un)belonging, due to their inherent multiplicity, allows us to examine, capture, and illuminate the dynamic and shifting ways in which people engage with the place they live in and the people around them. Feelings of (un)belonging allow for ambiguities and confusion, which are part of empirical and everyday realities. The notion of (un)belonging thus takes into account the messiness created by the intersection of different positions and categories. This messiness is exemplified by Seyit's defense of his own (un)belonging, which was shifting, ambiguous, and sometimes even contradictory.

\section{Introducing the quarrel between Seyit and the customer}

It is the afternoon of Thursday, January 10,2013, and the atmosphere in the supermarket is peaceful: it is not too busy, and Seyit has finally found time to rearrange products in the aisle where products from Surinam are found. Since his shop is still quite new, he continues to switch products around in order to make them more visible to customers. While I am helping customers pack up their products into plastic bags at the cash desk, a woman queues up to buy sausages and cheese. When paying, she digs up many coins from her wallet and starts counting aloud. Nearing the total amount she has to pay, she lays down coins of one and two eurocents. Sevim immediately interrupts the woman's counting and informs her that they do not accept these small coins. The woman responds in an annoyed manner that Sevim is not allowed to reject these coins and that she will report this to the designated authorities.

(Field notes, January 10, 2013)

Upon overhearing the customer, Seyit joined the discussion and tried to convince the customer that Sevim was allowed to refuse the coins (Extract 1a). The customer therefore declared that she would not buy anything because of that (Extract $1 \mathrm{~b}$ ). The argument reached its peak when the woman questioned the supermarket's and, on a more personal level, Seyit's practices by stating that "because here we live in the Netherlands here," he should have accepted these coins (Extract 1c). After stating this, she exited the store without buying a thing, leaving behind a flabbergasted Seyit. Too astonished to immediately react to the incident, he at first resumed his task of rearranging products not far from the cash desk. After a few minutes, he returned to Sevim and me to evaluate the conversation and the woman's statement. At that point, his astonishment was replaced by anger, and he kept rehashing and re-enacting the statement for over half an hour to Sevim, me, and other customers. 
When I informed Seyit that before he had joined the discussion, the woman had threatened to report the rejection of the coins to the authorities, he sarcastically and rhetorically responded by asking if she planned to bring the report to Bosnia, thereby revealing the woman's Bosnian background (Extract 2a). Seyit pointed out that the woman was not entitled to make a statement like "because here we live in the Netherlands," given that he had been living in the Netherlands longer than she had (Extract 2b). Above all, Seyit told me that the woman had denied where she was originally from, which, in his eyes, was the worst thing one could do. It is here where the conditions and norms of foreignness were constructed.

Resuming our jobs, I asked Seyit something about the tasks we were performing (Extract 3). My question evoked a humorous yet serious discussion, with Seyit's addressing the current polarized state of affairs in the Netherlands and explicitly referring to political anti-immigration statements. The fact that this innocent question about our work routine incited Seyit's anger about the challenging statement, "because here we live in the Netherlands," shows that the interaction with the woman had profoundly challenged his own feelings of belonging.

When Seyit explained to a male customer what had happened, the requirements and norms of shared feelings of foreignness were further negotiated and constructed (Extract 4). In this conversation, I argue that Seyit and the male customer were legitimating their own belonging to the Netherlands while at the same time constructing, negotiating, and claiming foreignness. Moreover, (linguistic) requirements for being an authentic foreigner or Dutch person were constructed in the conversation of Seyit and the customer (Extract 5). Eventually, when Seyit's irritation had subsided a little bit, he started recapitulating the discussion (Extract 6). I argue that his recap highlighted the inner conflicts someone can have when dealing with belonging, thus exemplifying the shifting, ambiguous and contradictory nature of feelings of (un)belonging and how people give shape to politics of (un)belonging in daily interactions.

\section{"Because here we live in the Netherlands"}

Extract 1a below reflects the moment that Seyit joined the discussion with the female customer at the cash desk, right after she had told Sevim that it was not permissible to refuse small coins of one and two eurocents and that she would report this to the authorities. When she saw Seyit approach the cash desk, she immediately asked him why they (the employees of Dost Market) refused the coins (Line 1). Seyit responded that he could not accept these coins, because he could not use them (Line 2). The woman argued that he was not allowed to do so (Line 3). Seyit further argued that the coins were accepted nowhere (Line 4), to which the woman replied that that was not true and that one is not allowed to refuse money (Line 5). Seyit repeated that it was allowable and that one can have one's own policy regarding coins (Line 6).

\section{Extract 1a}

1 Woman Waarom weigeren jullie twee en een cent, dan mag je dat niet weigeren. Why are you refusing two and one cents, then you may not refuse it.

2 Seyit Maar ik kan hem niet aa/ ook niet aannemen want ik heb d'r niks an. But I can't aa/ accept it either, because I can't use it.

3 Woman Maar dat mag je niet. But you cannot. 
4 Seyit Ja, kijk, bijvoorbeeld, nergens wordt aangenomen.

Yes, look, for example, it's accepted nowhere.

5 Woman Nee, dat is niet waar, jij mag geld niet weigeren.

No, that is not true, you may not refuse money.

6 Seyit Je mag hem wel weigeren, je mag eigen policy, mag je weigeren.

You may refuse it, you can have own policy, you may refuse.

[Silence for (.3)]

Extract 1a shows how Seyit and the customer got into a discussion about the coins. The interaction could be regarded as a 'talk' that is "naturally bounded, ritually bracketed, (opened and closed), displayed in bodily orientation" (Goffman 1981: 130-131).

After a short silence, the customer decided that she would not buy anything because of this (Line 7 in Extract $1 \mathrm{~b}$ below). She strengthened this claim by adding that she balked at that, for which she used the expression dat verrek ik echt (Lines 7 and 9). This expression would generally be interpreted by people from Limburg as being a local way of saying that one refuses to do something. Outside of Limburg, verrekken generally means 'to starve' or 'to pull a muscle.' In Lines 8 and 10 Seyit calmly affirmed that it was possible for her not to buy anything.

\section{Extract $1 b$}

7 Woman Dan koop ik hier niks, dat verrek ik echt.

Then I do not buy anything here, I balk at that.

8 Seyit Ja, dat kan.

Yes, that's possible.

9 Woman Dat verrek ik.

I balk at that.

10 Seyit Dat kan.

That's possible.

While Seyit's calm response seemed to be the end of the discussion, the customer did not leave it at that and provided a reason in Line 11 of Extract 1c as to why she thought it was not allowable to refuse money. The statement "because here we live in the Netherlands" aggravated the situation and caused Seyit to raise his voice (see use of capital letters) and speak more rapidly (see [ac]) in Lines 12 and 14 when responding that he knew that "we" live in the Netherlands, since he lived in the Netherlands too and she did not need to tell him that. The woman decided not to react to Seyit and claimed that the coins were an official means of payment (Line 13) and that she would take back everything (Line 15). Leaving it at that, Seyit said that was no problem and that it was her own decision (Line 16).

\section{Extract 1c}

11 Woman Want hier [ac] \{wonen wij\} in Nederland!

Because here [ac]\{we live\} in the Netherlands!

12 Seyit =NEE WIJ WONEN IN NE/!

$=N O$, WE LIVE IN THE NE/!

13 Woman =DIT IS GEWOON OFFICIËLE BETAALMIDDEL!

$=$ THIS IS JUST OFFICIAL MEANS OF PAYMENT! 
14 Seyit $\quad[a c]\{$ Wij wonen, ja, wij wonen in Nederland, ik woon ook in Nederland, dat weet $i k$, =dat hoef je me niet te vertellen, $=\}$

[ac] \{We live, yes, we live in the Netherlands, I live in the Netherlands too, I know that, =you don't need to tell me that $=$ =

15 Woman = $\underline{\text { Ja }}$, maar dat is officiële betaalmiddel, dan neem ik alles terug.=

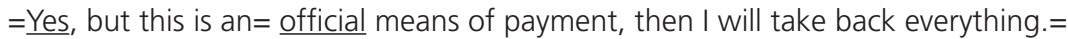
16 Seyit Ja dat is geen probleem, dat moet $\mathrm{u}$ zelf weten.

Yes, that's not a problem, it's your decision.

When the customer had almost left the store, she claimed that Seyit should accept the coins "because here we live in the Netherlands" (Line 11). This statement was the immediate cause of Seyit's continued anger and frustration (which lingered on for more than half an hour afterwards). The woman tried to reprimand Seyit, and this expression showed that she was critical of the supermarket. Using conversation analytical transcription for Line 11 shows that the woman stressed "here" and "The Netherlands" while "we live" was pronounced faster than the rest of the sentence:

\section{Extract 1c}

11 Woman Want hier [ac] \{wonen wij\} in Nederland!

Because here $[a c]\{w e$ live $\}$ in the Netherlands!

The woman thus stressed the place they found themselves in: here in the Netherlands. The use of this specific word "here" implied the place where the woman and Seyit were at that exact moment, namely, the Netherlands. It was as if the woman were pointing out to Seyit that 'we do not live in the country you are coming from, where you can get away with these kinds of practices maybe; we live in the Netherlands where you should conform to Dutch rules.' Aside from that, her use of "we" seemed to explicitly exclude Seyit from that group of "we." With her use of "here," "we," and loud, authoritative voice, the woman took on the mantel of authority to judge Seyit's practices and those adopted in his supermarket. In doing so, Seyit saw his belonging as being questioned. This became evident when he explicitly defended his belonging to the Netherlands in Line 14: "ik woon ook in Nederland" ("I live in the Netherlands too"). As other extracts later on in the chapter will show, he also identified with other places and groups, thereby underlining the ambiguity of belonging (see Yuval-Davis 2006).

Examining the woman's language practices makes it possible to deduce possible aspects of her individual biographical trajectory (cf. Blommaert 2010). For instance, the following utterance in Line 13 demarcates the struggle most bilingual speakers of Dutch have with the flection of adjectives in Dutch, which should be without an 'e' before a neuter noun betaalmiddel (Cornips 2008):

\section{Extract 1c}

13 Woman = DIT IS GEWOON OFFICIËLE BETAALMIDDEL!

$$
=\text { THIS IS JUST OFFICIALLY MEANS OF PAYMENT! }
$$

The flection of Dutch attributive adjectives is dependent on whether an indefinite noun is common or neuter. Betaalmiddel is referred to by the neuter determiner het. This means that no adjective gets the ' $\mathrm{e}$ ' flection. It should be officieel instead of officiële 
betaalmiddel. From the literature, it is known that bilingual speakers of Dutch may struggle with neuter gender on adjectives and definite determiners in Dutch, resulting in sentences similar to what is presented above (Cornips 2008).

Another explanation for officiële betaalmiddel could be that the woman's first language (a Slavic language) does not include the use of articles. From this perspective, officiële betaalmiddel is not about the flection of the adjective, but the result of transfer from her first language. In this case, the phrase is not about the woman's ignorance of flection rules, but, rather, that she literally translated the sentence from Bosnian, which resulted in dit is gewoon ø officiële betaalmiddel, instead of dit is gewoon het officiële betaalmiddel. In addition to these grammatical rules, the woman pronounced the word betaalmiddel in a different way than is usual in Dutch. Instead of [bəta:Imıdəl], she said [bətal:mi:dəl], thereby lengthening the sound of the [i] in middel. Depending on the interpreter, these utterances and pronunciation may signal the so-called 'non-native' or 'migrant' background of the speaker.

After this discussion, the woman collected her money, left her groceries behind on the conveyor belt and walked out of the store. Seyit immediately resumed his stocking tasks, seemingly unaffected by the discussion. Yet the following extracts will show that he was in fact disturbed by the discussion and the woman's accusation of "because here we live in the Netherlands." In this case, in Duchêne's and Heller's words (2012), pride surpassed profit. Seyit did not try to sell his products in order to earn profit, not at the cost of letting someone challenge his belonging to the Netherlands. The next section explores how Seyit defended himself by claiming and justifying his own feelings of belonging while challenging the woman's belonging.

\subsection{Politics of (un)belonging in interaction: claiming, justifying, and challenging}

Drawing on Bucholtz and Hall (2004), I will discuss what politics of (un)belonging were salient to Seyit, in which we witnessed his aligning with and relating to the Netherlands, feelings of foreignness, and Limburg. The following extracts present the conversation Seyit had with me concerning the discussion in Extract 1.

After Seyit had digested his discussion with the woman, he returned to the cash desk to talk about the incident with Sevim and me. Sevim told him that the customer had tried this before, and that she knew very well that they did not accept small change. Extracts 2 and 3 could be described as an open state of talk, in which "the conversation is subordinate to an ongoing task [and] participants hav[e] the right but not the obligation to initiate a little flurry of talk, then relapse back into silence, all this with no apparent ritual marking" (Goffman 1981:134). Seyit and I were completing our tasks while Seyit continued complaining about the woman's statement. I informed Seyit that the customer had said she planned to report the incident to the authorities. In response, and clearly agitated, he sarcastically and rhetorically asked if she were going to bring the report to Bosnia (Line 1 and 2). Then he repeated the statement "we live in the Netherlands" (Line 3), after which he acted as if he were still talking to the customer, whom he addressed as "girl" (Line 4). In Line 5, Seyit defended himself by stating that he was born and raised "here" and wondered what "she" was talking about, since she had only been living in the Netherlands for just a few years. By adding an emphatic "seriously!" (Line 6), Seyit tried to convince me that he was telling the truth about the customer. 


\section{Extract 2a}

1 Seyit $\quad$ [ac] $\{J a$, en dan? Wat gaat ze doen, naar Bosnië brengen? (.2)

[ac] \{Yes, and then what? What is she going to do, bring it to Bosnia? (.2)

2 Seyit Gaat ze naar Bosnië, een notitie maken?

Is she going to Bosnia, make a report?

3 Seyit Wij leven in Nederland.

We live in the Netherlands.

4 Seyit Meid, wij leven in Nederland.

$\underline{\text { Girl, }}$, we live in the Netherlands.

5 Seyit Ik ben hier, eh, geboren, getogen en wat praat jij nou, jij bent net een paar jaar hier.\} I was here, uh, born, raised and what are you talking about, you have been living here for just a few years.\}

6 Seyit Serieus!

Seriously!

In Extract 2a, many things become clear for the outsider: just like Seyit, the woman had a so-called 'non-native' or 'migrant' background, which seemed to make the event even more painful for him, since his belonging had been questioned by someone coming from a similar background. In Line 5, he stressed the fact that he had been living in the Netherlands longer than the customer had, thereby authenticating and essentializing himself as genuine or 'pure' Dutch (cf. Bucholtz and Hall 2004). Coupland (2003) has distinguished different dimensions of authenticity to which people might relate in constructing authentic places, traditions, or feelings of belonging. Seyit's claim to authentic Dutch belonging could be a connection to the dimension of historicity, since he was using history (his longer period of residence) in order to justify his claim to authenticity.

While authenticating himself, Seyit illegitimated the woman by symbolically addressing her as "girl" (Line 4) and used "what are you talking about" (Line 5) to highlight her inferiority in a derogatory manner, even though she was not present at the moment of this utterance. Antonsich (2010) affirms that length of residence can be considered relevant to generate place-belongingness, which is exemplified by Seyit's using his length of residence to legitimate his place-belongingness to the Netherlands. The self-repair in Line 5 about "being born, raised in the Netherlands" is interesting. Seyit was not born in the Netherlands, but moved here with his parents as a four-year-old boy. Although he wanted to use the expression 'to be born and raised,' he realized that this did not apply to him, even though it might feel that way. In addition to this, Seyit was challenging the woman's belonging to the Netherlands by stating that she had only been living here for just a few years (Line 5).

This argument got reversed in Extract 2b, when he continued to accuse the customer of denying where she was coming from (Line 7). This was, according to Seyit, the worst thing one could do (Line 8).

\section{Extract 2b}

7 Seyit $\quad[a c]\{$ Weet je wat\} zij ontkent ook nog eens waar ze vandaan komt, hè? [ac] \{You know what\}, she even denies where she's coming from, huh?

8 Seyit Dat is het ergste, ja (.) dat is het ergste wat je kunt doen, ontkennen. That's the worst, yes. (.) that's the worst thing you could do, deny it. 
After first adequating himself with having been born and raised in the Netherlands, Seyit adequated himself (Extract 2b, Lines 7 and 8) with coming from outside the Netherlands. From this perspective, he criticized the woman because she was seen to be denying her own origins. He probably based this on earlier experience with and knowledge of the woman, since there was no explicit evidence or reference to her denial on this particular day. However, according to Seyit, denying where one comes from is "the worst thing you could do." Seyit used the tactics of intersubjectivity (Bucholtz and Hall 2004) to nullify the woman's attempt to make an authoritative judgment like "because here we live in the Netherlands." Through the tactics of authority and authentication, Seyit established himself as being both authentic Dutch as well as authentic 'foreign' (mainly because he had been living in the Netherlands longer than the woman and because he probably stayed true to where he was originally from). Besides that, he illegitimated the woman's feelings of belonging by perceiving her as both artificially Dutch and 'foreign' (since she had only been here for a few years and she denied where she was coming from).

The authentication of Seyit exemplifies the influence of politics of belonging on place-belongingness (cf. Antonsich 2010; Yuval-Davis 2006). Through the woman's challenge of Seyit's belonging to the Netherlands, Seyit not only felt the need to assert his place-belongingness to both the Netherlands as well as to being 'foreign' but also to challenge the woman's belonging. Extract 2 shows that Seyit highlighted different emotional attachments depending on the context, which marks the intersectional nature of feelings of belonging, making them shifting and ambiguous (Yuval-Davis 2006). Seyit thus related to different 'modes of belonging' (Sicakkan and Lithman 2005) or 'differential belonging' (Rowe 2005), demonstrating a variety of attachments to different places, groups, and cultures (cf. Antonsich 2010).

Extract 2 shows how the intertwining of place-belongingness and the politics of belonging resulted in a narrative in which Seyit tried to defend and claim authentic belonging and legitimacy (ownership) on different scales while simultaneously challenging the woman's belonging. It is here that the messiness of belonging is most clearly exemplified and, as Pennycook and Otsuji (2016: 261) put it, reveals that people are "part of a more complex set of identity repertoires that are always being reworked." Moreover, Extract 2 confirms that the construction of belonging is always a relational process; the woman and Seyit needed each other in order to construct, challenge, and claim their belonging which, in his case, was shifting and ambiguous.

\subsection{Foreignness in practice: constructing norms of foreignness}

As argued earlier (Chapter 8, Section 8.1), Deniz's statement showed that the question of being buitenlander (foreigner) or not was highly important within the context of Dost Market:

\footnotetext{
"That's how foreigners do it! Are you a foreigner too?" "Half." "Half does not exist anymore, then you are a foreigner."

(Field notes, December 17, 2012)
}

This search for belonging through unbelonging is what I analyzed and proposed to call foreignness: a feeling existing between two or more persons based on shared otherness in comparison with others who define themselves as 'natives' and as naturally 
belonging to the place where they live. In Extract 2 (Lines 7 and 8), Seyit construed norms regarding foreignness:

\section{Extract 2b}

7 Seyit [ac] $\{$ Weet je wat\} zij ontkent ook nog eens waar ze vandaan komt, hè? $[a c]\{Y o u$ know what\}, she even denies where she's coming from, huh?

8 Seyit Dat is het ergste, ja (.) dat is het ergste wat je kunt doen, ontkennen. That's the worst, yes. (.) that's the worst thing you could do, deny it.

According to Seyit, foreignness should not be denied, and one should stay true to the place one comes from originally. Denying where one comes from, as the woman supposedly did, was therefore the worst thing one could do. The 'crisis of home' (Duyvendak 2011), processes of continual othering (Ghorashi 2002), and the increasing popularity of antiimmigrant political parties (Prins 2002) have fostered the need for bonding through foreignness, based on shared feelings of belonging through unbelonging among people perceived as sharing some kind of otherness in comparison with others who naturally claim to belong to the place where they live. As was found in the studies of Dorleijn and Nortier (2005) and LePage and Tabouret-Keller (1985), such feelings of belonging through unbelonging may result in feelings of foreignness and solidarity among a group of people that are generally perceived as 'the other' on the basis of difference, be it appearance, language practices, or religious affiliation. Apparently, due to the fact that they shared a so-called 'non-native' or 'migrant' background, Seyit believed that the woman should share feelings of foreignness and appreciate where she came from. In a way, it seems as if Seyit had accused the woman of betraying foreignness. This clearly underlines the fact that there is no correlation to be drawn between a person's so-called 'non-native,' 'migrant' background and foreignness and people's dealing with foreignness in dynamic and shifting ways. This is also exemplified by Seyit who, on the one hand, alluded to a form of shared foreignness which should be respected, but, on the other hand, clearly demarcated himself from the woman, since he had been living in the Netherlands for a longer period of time than she had.

In Extract 3, Line 1, I asked Seyit whether the shelves that I was stocking were vol (full). This immediately reminded Seyit of Dutch right-wing politician Geert Wilders, who had made the statement that $\mathrm{vol}$ is $\mathrm{vol}$ (full is full), by which he meant that immigrants should be stopped from entering the Netherlands, since the country was becoming too crowded (Line 2). Seyit indignantly remarked that I should not say that and that he did not expect this from me (Line 3), at which point I tried to defend myself by saying that I was talking about the peas I was stocking (Line 4). Seyit repeated that he did not expect this from me (Line 5) and that I should act "normal," since vol is vol is something you should not say; no, rather, half empty (Line 6).

\section{Extract 3}
1 Lotte
Vol?
Full? [about a product]
2 Seyit $\quad[a c]\{$ Vol is vol\}! Geert Wilders zegt dat. [ac]\{Full is full\}! Geert Wilders says that!
3 Seyit Dat zeg iij toch niet? Sjonge jonge jonge, dat had ik niet van jou verwacht. You wouldn't say that? Oh, oh, oh, I didn't expect that from you.
4 Lotte $\quad=$ Dat zei ik niet, ik had het over die erwten van je!= $=$ I didn't say that [laughs], I was talking about those peas of yours!= 
5 Seyit =Dat had ik echt niet verwacht, niet normaal!=

$=$ really didn't expect that, not normal!=

6 Seyit Doe normaal, dat zeg je toch niet, vol is vol! Vol! (.3) Nee, halfleeg.

Act normal, you should not say that, full is full! (.3) Full! No, half empty.

The word "full" in Line 1 of Extract 3 reminded Seyit immediately of vol is vol (full is full), a phrase frequently used by politicians who are in favor of closing the borders to immigrants, such as the right-wing politician Geert Wilders. Since the phrase "full is full" is regularly employed by these anti-immigrant politicians, the word vol has a certain symbolic meaning, which is particularly meaningful to those people that interpret and understand the unpleasant message concealed in the phrase (Kazemi 2012). In Seyit's eyes, the word vol was indexical (Eckert 2008) of anti-immigrant and xenophobic sentiments, from which he distanced himself by theatrically judging me for using the word vol, even though I had used it to refer to the stocked shelf. Moreover, Seyit drew a boundary between those people who think like Wilders (whom he judged) and those who do not. By repeating the word "normal" in Lines 5 and 6 two times, Seyit presumably also related to a dispute within the House of Representatives of the Netherlands in which Geert Wilders yelled doe eens normaal, man (act normal for once, dude) at the prime minister of the Netherlands. ${ }^{82}$

Hymes (1974: 57) understands 'key' as the tone, manner, or spirit in which an act is done. Even though I laughed when Seyit accused me of parroting Wilders, the tone of his reaction was not humorous, but, rather, serious and condemnatory, which is why I attempted to defend myself by saying that I did not say that at all. After our discussion, he did not say 'just kidding,' which suggested that he was indeed quite serious and still agitated. Seyit's swift response to the word vol should be interpreted in the light of the earlier quarrel with the customer about the refusal of small change, which openly challenged his belonging to "here," the Netherlands, in the same manner as phrases like vol is vol do. Extract 3 thus exemplifies Seyit's heightened awareness of and sensitivity to questions of belonging and foreignness in the light of current politics and heightened polarization in Dutch and other Western societies, which are increasingly critical and suspicious of immigrants, or anyone with a so-called 'non-native' or 'migrant' background or appearance that deviates from the so-called Dutch norm.

\subsection{The ambiguities of dialect use in the construction of foreignness}

After the vol is vol discussion, Seyit and I resumed stocking shelves until a male customer approached Seyit. Still agitated, Seyit immediately informed the man that "that woman" had been in the supermarket, and the man guessed who Seyit was talking about (Line 1), referring to her as "the Bosnian" (Line 2). ${ }^{83}$ Seyit affirmed this, and when he started to

\footnotetext{
82 This confrontation between right-wing politician Geert Wilders and prime minister Mark Rutte took place on September 22, 2011, during the general debates at the House of Representatives of the Netherlands (see also Boon 2012: https://www.nrc.nl/nieuws/2011/09/22/wilders-tegen-rutte-doe-eens-normaal-mana1452582).

${ }^{83}$ For the sake of privacy, I have deliberately omitted Seyit's explicit reference indicating which woman he was talking about with the male customer and replaced this with ' $x x^{\prime}$ ' in Line 1 of Extract 4.
} 
relate the discussion he had had with the woman (Line 3), the man interrupted by rhetorically asking whether she was not a Bosnian at all (Line 4). Seyit agreed that she had become Hollandic (Line 5), and the man added that she was African (Line 6). Seyit quickly agreed, so that he could finally get on with retelling the story.

\section{Extract 4}

1 Seyit Net was dinge hier hè, die vrouw van xxx

Just now, whatshername was here, huh, that woman of $x x x$

2 Man Die vrouw? Oh, die Bosnische!

That woman? Oh, the Bosnian!

3 Seyit a, die Bosnische vrouw, luister, zij komt zo,

Yes, that Bosnian woman, listen, she comes just like that,

4 Man =Zij is helemaal geen Bosniër hè?

$=$ She is not a Bosnian at all, right?

5 Seyit $\quad=$ Ja, ze is Hollands geworden!

$=$ Yes, she became Hollandic!

6 Man Zij is, eh, Afrikaans.

She is, uh, African.

7 Seyit Ja, Afrikaans, ja, luister,

Yes, African, yes, listen,

8 Man Ja?

Yes?

In deciding which woman Seyit was talking about, the men exchanged labels in Extract 4. First, in Lines 2 and 3, the men referred to her as "the Bosnian." In Line 4, the man questioned that label by rhetorically asking whether she was not a Bosnian at all. Seyit immediately seemed to grasp what the man's intention was by saying this and corrected himself by ironically saying that she became Hollandic. The use of the label Hollands (Hollandic) is quite remarkable here and can index different things. On the one hand, it can index the general abbreviated name that people call The Netherlands, Holland. However, within the context of Limburg, 'Holland' and 'Hollander' have quite negative connotations, since they refer to everything that is outside of Limburg and not Limburgian (Thissen 2013 and Chapter 1 of this dissertation). Given Seyit's use and in light of the broader Limburg context in Extract 5 below, in which the men questioned the woman's use of dialect, it is likely that he intended the latter meaning.

In Line 6, the man referred to the woman as Afrikaans (African). The label "African" seems to be an exotic and distant label with which the men denaturalized (cf. Bucholtz and Hall 2004, 2005) the woman's attempt to be Dutch and emphasized that the woman behaved artificially. It seems as if they were trying to say that her belonging to the Netherlands was as artificial as if she had claimed to be African. The woman was denaturalized as being both artificially Dutch and artificially foreign (cf. Bucholtz and Hall 2004, 2005). In doing so, the woman was (again) implicitly criticized for denying foreignness by conforming to the Dutch environment. In contrast to newcomers who never know 'enough' Dutch to be considered 'authentic' (cf. Blommaert and Varis 2011) or fully 'integrated' into Dutch society (cf. Ghorashi and Van Tilburg 2006), the men seemed to judge the woman for doing too much in order to be regarded as Dutch. The men took up the authority to judge and reject the woman's efforts to be seen as Dutch. As a consequence, 
the woman was perceived by the men as not being a Bosnian anymore because she had become (too) Dutch. This, again, highlights the fact that feelings of belonging are always constructed in a relational process and that place-belongingness goes hand in hand with the politics of (un)belonging (cf. Antonsich 2010; Barth 1969; Ghorashi 2002). This means it is necessary for others to acknowledge or accept one's performed feeling of belonging.

After calling the woman African, Seyit related the discussion with the woman to the man. Unsurprisingly, the man was as astonished as Seyit, and they started to discuss the linguistic reasons why they perceived the woman as artificial and denaturalized, as reflected in Extract 5 below. After both repeated the statement (Lines 1 and 2), the man acted as if he were speaking as the woman and claiming that she was able to speak plat (Line 3), after which he added something in Turkish or Kurdish (Lines 3 and 4). ${ }^{84}$ Seyit clarified to me that the woman indeed talks plat in a really "illegal" manner, with which the man agreed (Lines 6 and 7). Seyit emphasized this once more (Line 8), after which the man said something in Bosnian (Line 9). ${ }^{85}$ This inspired Seyit to imitate the woman's alleged way of talking by combining linguistic forms associated with Bosnian with a local sounding variety of Dutch (Lines 10 to 11). To convey his disbelief, Seyit ended this portion of the interaction by exclaiming a local expression (Line 12).

\section{Extract 5}

\begin{tabular}{|c|c|}
\hline 1 Man & Eh, ja, wij wonen in Nederland, hè? \\
\hline & Uh, yes, we live in the Netherlands, right? \\
\hline 2 Seyit & Wij wonen in Nederland. \\
\hline & We live in the Netherlands. \\
\hline 3 Man & Ja, ik kan wel plat kalle hè! [Turkish/Kurdish (.2)] \\
\hline & Yes, but I do [dialect] talk plat [/dialect], huh! [Turkish/Kurdish (.2)] \\
\hline 4 Seyit & Ja. \\
\hline & Yes. \\
\hline 5 Man & [Turkish/Kurdish (.1)] \\
\hline 6 Seyit & $\begin{array}{l}\text { Ja! Zij pr, zij praat e:h plat e::h, echt illegaal. } \\
\text { Yes! She ta, she talks u:h plat u::h, really illegal. }\end{array}$ \\
\hline 7 Man & $\begin{array}{l}\text { xxx ja, illegaal plat. } \\
\text { xxx yes, illegal dialect. }\end{array}$ \\
\hline 8 Seyit & $\begin{array}{l}\text { Echt, echt illie. } \\
\text { Really, really illegal. }\end{array}$ \\
\hline 9 Man & $\begin{array}{l}\text { Dobre komsji! } \\
\text { [Bosnian] Dobre komsji![/Bosnian] }\end{array}$ \\
\hline
\end{tabular}

\footnotetext{
${ }^{84}$ Since I do not understand Turkish or Kurdish, I cannot differentiate between the two.

85 In Extract 5, I transcribe the words exactly as the men said them (komsji: komšija in Bosnian, dobre: dobro in Bosnian). These words may be meaningful for people who drive from Western Europe to Turkey during the holidays. On this route, they pass through Bulgaria, a country where the police and customs officers tend to ask for a lot of money to cross the border. If this amount of money is not paid, you run the risk of having to unpack your car or van completely so that the officers can check the luggage. In order to avoid these problems, the words dobre komsji and nema para, komsji can be used. It is unknown if Seyit and the man were aware of this context; it appears that they used the words to index a Bosnian person. Seyit often uses these words to greet customers coming from the Balkan.
} 
10 Seyit Dobre komsji, ik kan ook plat kallen hè?

[Bosnian] Dobre komsji [/Bosnian], [Limburgian dialect with Bosnian accent]

I can talk plat, right? [/Limburgian dialect with Bosnian accent]

11 Seyit Ja, nema para komsji!

Yes, [Bosnian] nema para komsji! [/Bosnian]

12 Seyit Ouw-hoer, man!

Holy cow, man!

While evaluating the woman's language practices and imitating them, the men gave more information about the reasons why they perceived her as artificial in Extract 5. In Line 3, the man remarked that the woman talks dialect, for which he used the dialect forms plat kallen, the popular way of saying 'to talk dialect' (see Chapter 3 and 4). To make sure that I heard this, he repeated this remark in Turkish or Kurdish to Seyit, who then repeated this claim in Dutch. By using the dialect words plat kallen, the men authenticated themselves by showing that they, in contrast to the woman, knew how to use the genuine dialect expressions, in Lines 3 and 10. In Line 12, Seyit exclaimed the local expression ouw-hoer, which literally translates into 'old whore' and is frequently used in Limburg as a tag in sentence final position (cf. Cornips and De Rooij 2015: 9). ${ }^{86}$ This use of local dialect forms resembles what Johnstone and Baumgardt (2004: 115) have called 'featuredropping': to display their knowledge of dialects associated with Limburg, the men used linguistic forms such as plat kallen and ouw-hoer, thereby claiming expertise and authenticity and proving to be legitimate speakers of dialect in contrast to the woman, while simultaneously producing localness. They thus explicitly exploited the power of language by using a linguistic form in order to underscore their belonging to Limburg (cf. Antonsich 2010).

As legitimate speakers of dialect, the men were permitted to evaluate the woman as illegaal (illegal) or - as they call it - illie, which they did in Lines 6 to 8.

\section{Extract 5 \\ 6 Seyit Ja! Zij pr, zij praat e:h plat e::h, echt illegaal. \\ Yes! She ta, she talks u:h plat $u:$, h, really illegal. \\ 7 Man $\quad$ xxx ja, illegaal plat. \\ xxx yes, illegal dialect. \\ 8 Seyit Echt, echt illie. \\ Really, really illegal.}

With these sentences, the men differentiated themselves from the woman, since they did know how to use dialect (illustrated by the use of plat kallen and ouw-hoer). "Illegal" or "illie" does not refer to legality in terms of law; rather, it is used as a symbolical

\footnotetext{
${ }^{86}$ In Cornips and De Rooij (2015: 9), the carnivalesque vocal group Getske Boys considers ouw-hoer to be an expression that is typically associated with the northern parts of Heerlen, a city located in the southeast of Limburg. Although it might have its origins over there, I would say that the form is widely used within the whole province of Limburg. I remember hearing the expression at school and while growing up in Roermond. It was considered coarse language, something you did not want to say in the proximity of your parents or teacher, and I would say that the expression was used more by boys than by girls.
} 
label to characterize language practices that are out of line with normal or standard varieties. This resonates with what Jaspers (2011) found amongst youngsters in Antwerp. These youngsters used the label of 'illegal talk' consciously to challenge and criticize existing stereotypes that perceived them solely as one homogeneous ethnic minority group and to construct a hierarchy within the classroom. In these extracts, the labels "illegal" and "illie" were used to judge others' language practices as artificial and denaturalized and consequently to judge their belonging to a particular place or group. On the one hand, the men judged the woman as being illegal, since she allegedly spoke plat with a Bosnian accent. On the other hand, the woman denied where she was coming from originally by adjusting too much, in the men's opinions, to the place she lives in and by acquiring dialect. The fact that the men used dialect forms (plat kallen and ouw-hoer) themselves did not keep them from judging the woman for speaking illegal plat and for being "African." This situated interaction at Dost Market thereby supports the idea, put forward by Franziskus et al. (2013), that language practices may be indicative of various kinds of power relationships. The men's judgment of the woman's artificiality (Afrikaans) and illegitimate language practices (illegaal plat) exemplifies that "power imbalances between different speakers are made relevant not only in the way these speakers use their language skills in order to pursue their linguistic interests, but also in the way they reflect upon language use" (ibid: 267).

The men's judgment of the woman for conforming too much to her environment resulted, I would suggest, in the constructions of norms for foreignness. These norms seem to prescribe how someone, who was considered by the men to relate to similar feelings of belonging through unbelonging based on shared otherness, should behave and affiliate. The role of dialect is very ambiguous in this sense, since, apparently, the woman had become "Hollandic" but at the same time spoke illegaal plat. The men seemed to be conveying that foreignness, in this context, cannot be combined with the use of dialect, despite the fact that they themselves also clearly conformed to their environment by using phrases and words like plat kallen and ouw-hoer.

Fixing language, place, and belonging

With regards to Extract 5, I want to finally point out how the men evaluated the woman by using traditional and dominant language ideologies that associate language, place, and belonging together (cf. Quist 2010). The imitation of the Bosnian words in Lines 9, 10, and 11 (dobre komsji 'good neighbor', nema para komsji 'no money neighbor') is meaningful, since the men thereby presumed a fixed connection of language, place, and belonging, inasmuch as Bosnian was probably the woman's first language.

\section{Extract 5}

$\begin{array}{ll}9 \text { Man } & \text { Dobre komsji! } \\ & \text { [Bosnian] Dobre komsji![/Bosnian] } \\ 10 \text { Seyit } & \text { Dobre komsji, ik kan ook plat kallen hè? } \\ & \text { [Bosnian] Dobre komsji [/Bosnian], [Limburgian dialect with Bosnian accent] } \\ & \text { I can talk plat, right? [/Limburgian dialect with Bosnian accent] } \\ 11 \text { Seyit } & \text { Ja, nema para komsji! } \\ & \text { Yes, [Bosnian] nema para komsji! [/Bosnian] }\end{array}$


Moreover, when Seyit repeated the dialect sentence "ik kan ook plat kallen, hè?" ("I can talk dialect, right?") in Line 10, he used an accent that could be interpreted as Bosnian. I suggest he did so to further emphasize how illegal and artificial her language practices were, in his eyes, since her Bosnian probably came through in her use of dialect. The men seemed to think that, since the woman was born in Bosnia, she should therefore speak Bosnian, instead of excessively conforming to the place in which she now lived by speaking the local dialect.

Even though the woman might be perfectly happy with her belonging and her languaging practices, the men's ideological stances were based on the essentialist presumption that a woman who is originally from Bosnia should speak Bosnian instead of excessively conforming linguistically to the place where she now lives. The men related to traditional and dominant language ideologies that constrained the use of dialect by someone born outside Limburg and, more important, outside the Netherlands, thus linking language, place, and belonging (cf. Quist 2010). The woman thus engaged in language practices that denaturalized these ideological expectations of the men (cf. Bucholtz and Hall 2004, 2005).

Seyit and the man criticized the woman's languaging practices, since, in so doing, she denied where she came from and tried to pass herself off as a Dutch and Limburger. In addition to their evaluation of the woman as no longer being a Bosnian anymore, but rather a Dutch or an African person, they regarded her language practices as illegitimate: illegaal plat kallen underscores this. One could even claim that she did not, in other words, fulfill the criteria for foreignness, since she seemed to conform to the Netherlands and Limburg too much in the men's opinion. As a result, the woman's attempt to be recognized as an authentic speaker of dialect was perceived as "illegal" by both men, who took up the authority to evaluate her linguistic practices.

Extract 5 exemplifies how people's daily practices and interactions reproduce essentialist language ideologies that assign a particular 'language' to a particular 'background' and how people use language to engage in "the dirty work of boundary maintenance" (Crowley 1999: 30 in Yuval-Davis 2006: 204). This does not mean, however, that Seyit's language practices corresponded with these traditional language ideologies; in his interactions with customers, Seyit engaged in languaging practices all the time (see Chapter 8). A revealing example of this in Extract 5 was Seyit's exclaiming of ouw-hoer (Line 12). Presumably, Seyit thought he was legitimately permitted to use such linguistic forms, because he had been living in the Netherlands and Limburg longer than the woman had and had thus gained authority to do so. This confirms that language ideologies are themselves also negotiated and emergent from people's practices (cf. Pennycook and Otsuji 2016). Although Seyit and the man expected the woman to be true to where she was coming from (Bosnia) by not linguistically conforming too much to her environment, Seyit himself engaged in languaging practices constantly, something he himself already told me during our very first encounter:

Language is everything. If you forget your language, you also forget your background, which is a shame. (...) Kurds in Turkey are becoming Turkish, because they are forced to forget their language. I myself feel Dutch as well, because that is the language I speak mostly.

(Field notes July 9, 2012) 
In this quote, Seyit explained why language was so important to him and also connected language practices directly to backgrounds, thereby reproducing a fixed connection between language, place, and belonging. At the same time, by saying that he felt Dutch as well, because that was the language he mostly used, Seyit's quote emphasizes the contextdependent nature of language practices and the ways that people experience feelings of belonging and unbelonging through language, illustrating how "people may have a range of ideologies available for thinking about language" (Pennycook and Otsuji 2016: 270). Similarly, the interactions so far have established that politics of (un)belonging emerge from the interactions and practices going on in a place and that people have a range of feelings of belonging and unbelonging that relate to different places, as Extract 6 will show next.

\subsection{The ambiguities of belonging and unbelonging: what is one's 'own' country?}

After the man left, Seyit and I started rearranging products again, while Seyit seemed to reflect on the whole situation in silence. After a while, he started to recap the discussion he had had with the woman by repeating once more the statement "we live in the Netherlands" and pointing out that he had heard that for the first time in the supermarket (Line 1). Astonished, he added that it had even been a "foreigner" who had made the statement, something that he would previously have supposed to be unimaginable (Line 2): a foreigner saying "we live in the Netherlands" (Line 3). He then said that he should have just gone with it by asking the woman whether they indeed really lived in the Netherlands (Lines 4 and 5). Seyit had informed me earlier that the woman was married to a 'native' Dutch man. After I asked him if Seyit thought she granted herself the right to make a statement like that due to having a Dutch husband (Line 6), Seyit grew even more annoyed, asking me rhetorically if having a Dutch passport made any difference, since he, too, had a Dutch passport (Line 7) and was, in fact, Dutch as well (Line 8). This seemingly made him ponder his own belonging and led him to engage in a self-reflective monologue about which was actually his "own" country.

\section{Extract 6}

1 Seyit Wij wonen in Nederland, dat hoor ik voor het eerst hier.'

'We live in the Netherlands, that's something I hear for the first time here.'

2 Seyit [ac]\{Door een buitenlander ook nog!\} Hoor je dat? Dat kan je toch niet geloven, hè? [ac][By a foreigner even!\} Do you hear that? You can't believe that, right?

3 Seyit Een buitenlander die zegt dat [ac]\{wij wonen in Nederland!\} (.8)

A foreigner who says, [ac] \{we live in the Netherlands! (.8)

4 Seyit Eigenlijk moest ik zeggen, oh ech waar? 'Wonen wij? ${ }^{\circ}$

I should have said, oh really? 'Do we live?'

\%[instead of using the Dutch linguistic form echt, Seyit's use of ech, with t-deletion in the end, is generally associated with Limburg]

5 Seyit $\quad x x x$ gewoon dinge meespelen, $x x x$ just go with it,

6 Lotte Eigenlijk raar, ze permitteert zich dat te zeggen omdat ze een Nederlandse man heeft, ofzo?

Strange, actually, she grants herself the right to say that because she has a Dutch husband, or what? 


\begin{tabular}{|c|c|}
\hline 7 Seyit & $\begin{array}{l}\text { Ja, en dan? (.) En dan? [ac] }\{1 \mathrm{k} \text { heb Nederlands paspoort, en dan? } \\
\text { Yes, so? (.) So ? } \text { ?ac] }\{1 \text { have a Dutch passport, so? }\end{array}$ \\
\hline 8 Seyit & $\begin{array}{l}\text { Ik ben ook Nederlander!\} } \\
\text { I am Dutch, too!\} }\end{array}$ \\
\hline 9 Lotte & $\begin{array}{l}\text { Ja, daarom. } \\
\text { Yes, that's why. }\end{array}$ \\
\hline 10 Seyit & $\begin{array}{l}\text { Ja. Ik woon meer hier dan in mijn eigen land. Toch? } \\
\text { Yes. [laughs] I live more here than in my own country. Right? }\end{array}$ \\
\hline 11 Seyit & $\begin{array}{l}\text { Eigen land, dit is mijn land! Ik ga toch niet terug! } \\
\text { Own country, this is my country! I won't go back anyway! }\end{array}$ \\
\hline 12 Seyit & $\begin{array}{l}\text { Ja, misschien als ik multimiljonair ben. } \\
\text { Yes, maybe if I'm a multimillionaire. }\end{array}$ \\
\hline
\end{tabular}

In the first lines of Extract 6, Seyit put his finger on the sore spot when clarifying why the discussion with the woman seemed to be a major source of irritation for him: the statement "here we live in the Netherlands" was made "door een buitenlander ook nog!" ("by a foreigner even!"). Similar to his earlier comment that the worst thing one could do would be to deny where one came from, Seyit seemed to accuse the woman of betraying shared feelings of foreignness through her seeming lack of solidarity with fellow 'foreigners' (cf. Dorleijn and Nortier 2005; LePage and Tabouret-Keller 1985). Line 4 exemplifies once more that Seyit's language practices included forms that are associated with Limburg: he used ech that, through the t-deletion of the Dutch word echt, is generally associated with Limburg.

When I asked him in Line 6 if the reason for her to make such a statement was because she had a Dutch husband, he immediately challenged this and stated that he had a Dutch passport and was Dutch, too. Seyit thereby used the authentication and distinction tactic (Bucholtz and Hall 2004) in order to draw a line between him and the woman and to legitimate his own belonging. Lines 10 to 12 reveal an almost inner conversation in which Seyit reflected on his own situation: first, he claimed that he lived more "here" than he did in his "own country." When reflecting on this (toch? 'right' in Line 10), he then changed his mind and said that he considered the Netherlands to be his country, since he would not go back (to Turkey) anyway. So, while judging the woman and challenging her belonging to the Netherlands and compliance with a potential shared foreignness, Seyit reflected upon his own feelings of belonging and unbelonging and concluded that he was Dutch, too, and that he actually considered the Netherlands as his own country. The interaction in the supermarket shows how politics of (un)belonging are shaped by using tactics of intersubjectivity (cf. Bucholtz and Hall 2004, 2005) in the justification and challenge of belonging as well as unbelonging. Through these tactics, Seyit aligned with foreignness, Limburg, and the Netherlands, while the woman was illegitimated as lacking the legitimacy to claim any of those feelings of belonging. Seyit thereby exemplifies how people may continuously redefine their feelings of (un)belonging within and to the places in which they live and that belongingness is anything but a final state-of-being that can be achieved (cf. Youkhana 2015; Yuval-Davis et al. 2006). 


\section{Conclusion}

This chapter provided insight into how people, by engaging in language practices with others, give meaning to the everyday places they inhabit. A close analysis of the situated interaction between Seyit and a customer at Dost Market presents the everyday linguistic construction of feelings of belonging and unbelonging within places. I have pointed out how the people involved in this situated interaction made use of the tactics of intersubjectivity (Bucholtz and Hall 2004) to align with or draw boundaries between themselves while also challenging and illegimating each other's feelings of belonging. It became clear that feelings of (un)belonging are manifested on different scales and can easily shift and be ambiguous and contradictory, depending on the context: Seyit's initial alignment with being Dutch shifted to aligning with foreignness, included the local scale of Limburg, and, in the end, returned again to the national level of the Netherlands. This chapter thereby exemplified how people appropriate the places they inhabit and make sense of and relate to the world around them, including the people they encounter. Moreover, this chapter's situated interaction has demonstrated that a place can never be perceived as static: it very much resides within the larger context of local, regional, national, and global scales and relations. Thus, both the place of Dost Market as well as feelings of (un)belonging and social relations of people inhabiting that place are in constant transformation.

Part III took the reader grocery shopping at Dost Market, a small-scale supermarket in the diverse neighborhood of De Donderberg in Roermond. The findings presented from Dost Market add to the insights offered in Parts I and II. Chapter 7 described the location of the store, its staff members and customers, and its products. In Chapter 8, I focused on the place-making processes that I observed within Dost Market. Just as in the research cases of De Katers from Maasniel and David and Zeegert on Munsterplein plaza, I have demonstrated how staff members and customers engaged in place-making practices within the place of Dost Market through languaging practices that made use of linguistic forms that they had acquired over the course of their lifetimes, including forms producing localness in Limburg. These linguistic place-making practices made up context-specific spatial repertoires upon which staff members and customers were able to draw in interactions and which were displayed in the linguistic landscape of the shop.

Similar to the case of David and Zeegert, the research case of Dost Market showed that linguistic forms associated with dialects in Limburg were not only used by so-called 'local-born' or 'native' inhabitants of Limburg. Establishing shared feelings of foreignness, based on feelings of being out of place and belonging through unbelonging within the Netherlands as a whole due to perceived otherness, seemed to be important to both staff members and customers at Dost Market. Yet the interaction in Chapter 9 demonstrated that belonging to the Netherlands as well as the province of Limburg turned out to be a point of contention among them as well, illustrating once more the dynamicity of place-making and politics of (un)belonging. Moreover, as in Parts I and II, in Dost Market there was also a discrepancy between what people say and believe they do and what they actually say and do (cf. Labov 1966) when examining situated interactions (Gumperz 1997). For example, Seyit's claim in Chapter 8 of feeling blöd (stupid) when speaking dialect and only doing it for fun, while challenging the woman in Chapter 9 for speaking illegaal plat, demonstrated that he nevertheless knew the norms for legitimate dialect use despite feeling uncomfortable speaking it himself.

Furthermore, my fieldwork experiences at Dost Market led me to coin the concept of foreignness, which I defined as a feeling existing between two or more persons based 
on some kind of shared otherness in comparison with others who define themselves as 'natives' or as naturally belonging to the place where they live. These so-called 'natives' usually consider the so-called 'non-native' others as newcomers or outsiders within a specific place (country, province, city, or even somewhere as local as a carnival association or supermarket) due to their 'origins.' Yet these allegedly 'non-native' people may very well have been born, raised, and/or living in that place for a lengthy period of time. Foreignness reflects the need that people might have to decide whether the people they encounter and interact with are in a position comparable to their own: they are perceived by others as not belonging in a particular place because of their imagined otherness. Within societies that are increasingly polarized, the need for shared foreignness gets enforced among those who feel excluded by society and politics, eventually nurturing feelings of belonging among them. Foreignness reflects, in short, belonging through unbelonging.

The situated interaction at Dost Market of Chapter 9 shows that belonging is an open nerve that is easily pinched, especially because of the increased importance of belonging in national public debates. Similar to the cases of De Katers and David and Zeegert, the research case of Dost Market exemplifies that discussions about belonging and, equally if not more important, unbelonging can thus be easily provoked in daily situations and may trigger intense emotions of authentication and illegitimation. Moreover, it is important to remember that foreignness can be constructed by anyone, regardless of that person's background and that norms of foreignness are highly dependent on the situation. In the following, concluding chapter, I will point out that the concept also is relevant to the research cases of De Katers and David and Zeegert. The grounded focus of this research on locations has facilitated the study of language practices that construct feelings of belonging and unbelonging, legitimacy, and, thereby, ideas about who is in or out of place, about who belongs or who unbelongs. This enables us to move away from relying on arbitrary and top-down categories, including labels such as 'native,' autochtoon, and allochtoon, as I will further argue in the Conclusion of this dissertation. 


\section{Chapter 10}

\section{Talking in and out of place: concluding remarks}

The aim of this dissertation was to examine how people use language in interactions with others to give meaning to the world around them. The study adopted a grounded theory approach, which resulted in using four so-called sensitizing concepts to explain the collected empirical data in three research locations: center-periphery dynamics, place-making processes, politics of (un)belonging, and foreignness (Chapter 1). These concepts turned out to be central to all of the chapters. As such, the dissertation clarified how people used language in everyday locations and interactions to shape place-making processes, politics of (un)belonging, and feelings of foreignness within various center-periphery dynamics that were perceived to be salient and dominant by the people in three research locations.

I employed ethnographic methods in order to examine how people appropriated places around them by attaching linguistic and cultural forms to these places and shaping ideas about who and what practices were considered appropriate or not. My awareness of the need for and use of ethnographic reflexivity enabled me to notice how people related to or responded to my own emplacement and embodiment. Moreover, by deliberately starting my research from locations, rather than focusing on categories of 'people' and 'languages,' this grounded study enhances our understanding of everyday language practices and the way that people deal with each other within particular locations.

My ethnographic fieldwork took place in Roermond, a city located in the heart of Limburg, a Dutch province that is generally perceived and imagined - by inhabitants of Limburg as well as people outside of it - as a province with a strong regional identity, based on particular traditions and the extensive use of dialects that are experienced and regarded as uniquely regional and local. It is due to this strongly perceived regional identity and Limburg's relatively recent integration into the Dutch nation-state in 1867 (Chapter 1) that this province provided a fascinating research context for studying center-periphery dynamics by scrutinizing the role of language practices in meaning-making processes within socially produced places and within social relations. Yet Limburg should not be perceived as a homogeneous province that lacks diversity and where people use just dialect. Roermond is the most culturally and linguistically diverse city in the province, followed by Maastricht (the capital, located in the south of Limburg) and Venlo (located in the north of Limburg). I conducted ethnographic fieldwork at three sites within Roermond: at the carnival association of De Katers (The Tomcats) from Maasniel (a former village that was 'annexed' by Roermond in 1959), in the city center of Roermond on Munsterplein plaza, and at the small-scale Dost Market supermarket located in De Donderberg, one of Roermond's neighborhoods.

Even though the three research cases each seemed to provide their own specific insights into how people used language practices to give meaning to places, and each case revealed different issues, each of the three cases contributed equally to answering the research question of how people used language in interactions with others to give meaning to the world around them. First, as people engaged in place-making processes through their language and cultural practices, they also conveyed their conceptions of who and what behavior were considered to be in and out of place. Second, people shaped, negotiated, and challenged feelings of belonging and, equally important, unbelonging in 
their everyday interactions, often in unpredictable ways. Politics of (un)belonging is not just something that is discussed in national and political discourse but is also shaped in the situated interactions of people. Obviously, the two realms stand in close juxtaposition with each other, and the current heightened awareness of societal polarization makes discussions 'on the ground' about belonging and unbelonging an open nerve that may be easily pinched, regardless of one's background.

In the following, I briefly summarize the research cases dealt with in the three parts of this dissertation, followed by the four conclusions I have drawn from my research. These conclusions will be followed by my elaborations on the implications of this dissertation for academia along with recommendations for society as a whole and suggestions for further research. Finally, I will clarify why I decided to title this dissertation Talking in and out of place by returning to my central argument.

\section{The research cases of Part I, II, and III}

The three research cases were deliberately selected to approach the research question from different perspectives. The celebration of carnival is generally imagined as the heyday for the strongly perceived regional identity and the dialects of Limburg while also being the period when carnival associations engage in carnivalesque and playful rivalries during speeches and events at carnival receptions. All of this contributes to making the celebration of carnival within a carnival association in Limburg an interesting focus for research (Chapter 3). The selection of De Katers (The Tomcats) as the specific carnival association for my fieldwork was motivated by the tumultuous history of Maasniel. This formerly independent village, with which De Katers is affiliated, was annexed - as members of De Katers called it - in 1959 by the city of Roermond. This historical occurrence lies, to this day, at the base of the widely propagated dialect motto of De Katers: Neel blief Neel (Maasniel remains Maasniel). By making use of fieldwork experiences, participant observations, and conversations with members of De Katers, Part I (Chapters 3, 4, and 5) of this dissertation sketched how these members employed linguistic forms in their carnival celebration practices. With these practices, De Katers carnival association appropriated Maasniel, which has become a neighborhood of Roermond, remembering and reproducing its former village identity, mainly through the use of symbols, such as clothing and tomcat statues, and dialect in place-making processes (Chapter 4). This research case demonstrated that carnival celebration practices at De Katers did not just reproduce the stereotypical and 'natural' association of the province of Limburg with carnival, dialect, and static ideas of 'Limburgerness.' Rather, this case showed that not just dialect alone was spoken in important carnival practices and, further, that carnival celebration was quite layered and complex in producing more local and smaller center-periphery dynamics than simply the Limburg vs. 'Holland' dynamic. It was within these center-periphery dynamics that place-making practices at De Katers conveyed ideas about who was in and out of place. I demonstrated that these ideas related to various center-periphery dynamics between Limburg vs. 'Holland,' Maasniel vs. Roermond, the center of Maasniel vs. other areas of Maasniel, and De Katers vs. other carnival associations (Chapter 4). Moreover, the staged discussion between the carnival's monarch and the national figure of Sinterklaas revealed how language practices challenge and subvert dominant center-periphery dynamics (Chapter 5). 
Part II carefully examined how two men in their interactions on Munsterplein plaza in the city center appropriated Limburg and Roermond as a place where they openly declared that they felt out of place (Chapter 6). The analysis of their linguistic and cultural practices, however, revealed ambivalent feelings of belonging and unbelonging, depending on the context, and suggested that the men bonded on the basis of a sense of belonging through unbelonging. The interaction and its analysis clearly demonstrated the added value of ethnographic reflexivity, since it was only because of my own presence that I learned how both men interpreted my appearance and how this affected their negotiation and challenge of politics of (un)belonging.

Part III dealt with fieldwork insights from a supermarket (Dost Market) located in Roermond's De Donderberg neighborhood (Chapter 7). This neighborhood is generally perceived as being quite diverse, where people from different backgrounds live. These people encountered each other at Dost Market when shopping for groceries and making use of linguistic forms that are associated with different languages. Embodied fieldwork experiences within Dost Market prompted me to develop the analytical concept of foreignness to capture forms of belonging through unbelonging and people's efforts to establish and bond over a sense of shared otherness within a particular place (Chapter 8). The situated interactions and conversations with staff members and customers of Dost Market made it clear that people may attach various linguistic forms to a place in order to give meaning to that place (Chapter 8). The language practices of staff and customers also revealed how they affiliated and expressed various feelings of belonging and unbelonging. Dependent on the situation and context of interactions, people accentuated different feelings of being in and out of place. The analysis of situated interactions between a staff member and his customers particularly highlighted how people employed linguistic forms to claim, legitimize, and challenge feelings of belonging and unbelonging, which were revealed to be dynamic and even contradictory (Chapter 9).

\section{Four conclusions}

I will now elaborate on four central conclusions that I wish to make with regard to the sensitizing concepts of this dissertation. The three research cases, although they involved a variety of people, practices, and places, appear to share a number of similarities. My four conclusions clarify how the research cases in the three parts of this book contribute to an understanding of how people give meaning to the places they inhabit and the people with whom they interact.

\section{Language practices are not fixed to particular speakers}

This dissertation's three research cases clearly untie the assumed link between language, place, and body (cf. Quist 2010) and, as such, underscore the fact that one cannot predict someone's language practices or connect language practices to particular speakers merely on the basis of their background, place of birth, or appearance. The people involved in the research cases of this dissertation, regardless of whether they are seen as 'natives' or 'nonnatives,' all used language as a resource to draw upon according to the places they found themselves in and the tasks they were performing, and thus engaged in constructing spatial repertoires (cf. Johnstone 2013a; Møller and Jørgensen 2009; Pennycook and Otsuji 2014a). 
Furthermore, the actual language practices and language ideologies that people created and adhered to differ. For instance, while strongly asserting that dialect is used exclusively in carnival celebration, the monarch of the carnival association switched to Dutch on stage to resolve a language discussion during one of the most important carnival practices, whereas Sinterklaas as a national figure switched to dialect during the same event on the same stage. The two men on Munsterplein plaza claimed not to be Limburgers and declared that they felt out of place, though, at the same time, they used linguistic forms and engaged in cultural practices that are generally associated with Limburg, thereby suggesting that they were more in place than they initially asserted. Similarly, the co-owner of the supermarket used dialect forms quite fluently in situated interactions with customers, yet clung to the idea that it was stupid for him, a Turk, to talk dialect. An important finding is thus that there is a difference between what people say and believe they do and what they actually say and do (cf. Labov 1966), which becomes clear when examining situated interactions (Gumperz 1997).

Place-making processes express who and what behavior are considered in and out of place and how people linguistically affiliate with or differentiate themselves from others

This dissertation provided examples of how people transform spaces into socially produced places (Cresswell 2009; Pred 1985); that is, by using linguistic and cultural forms, people are able to give meaning to the world and people around them. As part of this process, I have suggested that two forms of place-making stand in juxtaposition with each other: broader place-making processes that connect places as a whole (villages, cities, regions, countries) to particular linguistic and cultural forms, such as the indexical, yet stereotypical, link between the province of Limburg with dialect use and carnival celebration. On the other hand, more individual and local place-making processes arise from people's practices, activities, and interactions with others in everyday situations and locations. These daily place-making practices 'on the ground' are informed by general indexical meanings that are the result of broader place-making processes: the place-making practices of the men on Munsterplein plaza showed that they did not recognize themselves in dominant (stereotypical) conceptions that link particular linguistic forms with Limburg, even though they themselves used these linguistic forms.

Through place-making practices, people distinguish themselves and the place they inhabit from others and other places by defining what is and is not considered appropriate behavior (Cresswell 1996): who or which behavior is perceived as being in and out of place. These research cases have shown how the display of linguistic forms in (public) space may sustain these conceptions of what is considered appropriate in that place or not. The use of dialect is connected to and expected in the context of the carnival association; dialect use was deemed to be in place and the use of Dutch out of place, whereas other languages were not even considered in this opposition (Gal and Irvine 1995). Similarly, the use of linguistic forms associated with a variety of languages was considered to be in place and, as such, appropriated, accepted, and valued in the context of the supermarket. Place-making processes are not necessarily 'positive' in the sense that place-making only provides a comfortable feeling of being at home or in place; rather, place-making processes can also very well result in feelings of being out of place. Placemaking practices and processes are, moreover, never static and ideas about who or which behavior is considered in and out of place depend on the context. 
Center-periphery dynamics recur on different scales and perceived peripheries are not just linguistically homogeneous entities lacking diversity

Place-making practices may relate to and reproduce power relations between perceived centers and peripheries on different scales ranging from, for example, the Netherlands as a whole, the province of Limburg, the city of Roermond and/or the neighborhoods of De Donderberg and Maasniel, resulting in recurrent and smaller center-periphery dynamics. The findings in this dissertation underscore the fact that perceived peripheries at the national level, such as Limburg, are far more dynamic than generally assumed (cf. KellyHolmes and Pietikäinen 2015) and that these areas have agency in creating center-periphery dynamics of their own (cf. Inda and Rosaldo 2008; Tsing 2005). As such, boundaries and categories of center and periphery are constructed, negotiated, and challenged through language practices (cf. Pietikäinen et al. 2016), and constellations of centers and peripheries are continuously changing, disappearing, and reappearing through people's practices (cf. Harrison 2015).

Moreover, all three research cases revealed that peripheries should not be mistaken for homogeneous areas where people live in harmony and where cultural and linguistic diversity are absent (cf. De Lima 2012). Languaging practices are also found in perceived peripheral areas (cf. Wang et al. 2013). The case of the carnival association showed that dialect was not always the appropriate language variety to use and that language routines could be broken temporarily. The case of the two men on Munsterplein plaza demonstrated that, even though they used linguistic forms associated with Limburg, one cannot discount their feelings of being in or out of place because of that. Finally, the supermarket was another case that made a compelling argument to go beyond the idea that Limburg, as a peripheral area, is a place where linguistic and cultural diversity include only dialect and carnival practices, since linguistic forms associated with, among others, Moroccan Arabic, Polish, French, English, and Turkish were used as well. This case further demonstrated that the store was at the same time very much embedded in the local context of Limburg, due to the use of dialect and language ideologies prevailing among the staff members of the supermarket.

Foreignness: belonging through unbelonging can be experienced by anyone

Shared otherness can be important to people, as these research cases pointed out. Foreignness was defined as a feeling existing between two or more persons based on some kind of shared otherness in comparison with others who define themselves as 'natives' or as 'naturally' belonging to the place where they live and who 'naturally' link 'a' certain language to that place. These so-called 'native' people usually consider so-called 'non-native' others as newcomers or outsiders within a specific place (country, province, city, or even within the small-scale context of a carnival association or supermarket) due to their 'origins.' Yet these allegedly 'non-native' people may very well have been born, raised, and/or living in that place for a lengthy period of time. The concept of foreignness reflects the need that people may have to decide whether their interlocutors are in a position comparable to theirs: due to their imagined otherness, they are perceived by others as unbelonging in a particular place.

Even though the notion of foreignness was initially inspired by the research case of the supermarket, in hindsight, the notion seamlessly applies to all three research cases. The 
carnival association actively remembered and reproduced a strongly perceived local identity, which only developed after Maasniel's annexation by the city of Roermond - thereby sharing similarities with Limburg's negative integration (cf. Knotter 2011) into the Netherlands as a whole. In the carnival event of De Katers (Chapter 5), Sinterklaas was initially perceived as being the odd one out. It was through the explicit language discussion and code-switching of both the carnival monarch (to Dutch) and Sinterklaas (to dialect) that the otherness of Sinterklaas was incorporated into the event. As a result, Sinterklaas and De Katers were able to bond on the basis of, first, Limburg's foreignness within the Netherlands and, second, Maasniel's foreignness within Roermond to create a shared understanding of what it was that was going on there. The two men in Chapter 6 who claimed not to be Limburgers presented a specific form of belonging, namely a feeling of belonging through a shared feeling of unbelonging: they bonded because they both felt a sense of unbelonging within Limburg due to the fact they were not born in the province but elsewhere in the Netherlands. Foreignness may thus be seen as a kind of belonging through unbelonging, underscoring once more that belonging cannot be studied without taking into account feelings of unbelonging. In other words, the men's shared foreignness created the basis for understanding between them about their ambiguous feelings of being both in and out of place within Limburg and Roermond. Within the supermarket, staff members as well as customers engaged in guessing games to find out about shared otherness within the Netherlands on the basis of their so-called 'non-native' backgrounds. Situated interactions at the supermarket revealed how people negotiated foreignness with each other while also constructing norms of what was considered appropriate behavior when sharing foreignness.

What this dissertation has shown throughout the research cases is that foreignness refers to a feeling that can be constructed at any time and place, and, more important, by anyone - not only those people who are, in common public discourse, regarded as 'non-natives.' Even those people who are generally perceived as 'natives' or, as they are referred to in Dutch, autochtonen (autochthons), can feel foreign depending on the situation, context, and language and cultural practices at play in a particular place (Chapters 5 and 6). Conversely, people who are regarded as allochtonen (allochthones) may feel 'native' depending on the situated interaction (Chapter 9). The research cases demonstrated that feelings of foreignness are thus dynamic rather than permanent: at one point, a person may affiliate with a certain place while at another that individual may feel out of place. Thus, foreignness is a cultural construct that is relevant in cases where people can compare each other with so-called significant others.

\section{Academic relevance and implications}

This dissertation has demonstrated the value of examining people's language and cultural practices within a location instead of focusing on 'a' group of people (Johnstone 2013a; Pennycook and Otsuji 2015). In this way, it becomes possible to understand cities, villages, and neighborhoods not just as an accumulation of different groups living side by side, each with its own practices. Rather, such a perspective reveals a multiplex of social meanings and helps us to understand what kind of place a fieldwork site is and how people engage in place-making processes that make places linguistically and culturally meaningful to them. In so doing, it becomes possible to discern the many linguistic and cultural crossovers that people shape throughout their lives. 
My first hope is that this dissertation has underlined the importance and added value of reflexive ethnographic methods in which researchers are aware of and make the most of the roles and influences they have on studied fields. In this dissertation, explicit awareness and reflexivity about my own embodiment and emplacement added to my understanding of how people deal with each other while affirming that the cultural context of 'where you are at' articulates the meaning of 'where you are from' (Ang 1994: 35): my own embodied presence was interpreted by others differently, depending on the location in which I found myself.

My second hope is that this dissertation will achieve its goal of encouraging social scientists, and cultural anthropologists in particular, to include closer analysis of language practices into their future studies. The study of language use plays a vital role in understanding people's place-making processes and the production and experience of belonging and unbelonging. When one carefully takes into account people's actual and daily language practices, the labeling of people in a top-down manner as being 'Dutch,' 'Limburger,' 'Turkish,' or 'Hollander' becomes much more problematic. Moreover, when examining the ways in which places become meaningful to people (Cresswell 1996), the examination of language practices is of crucial importance in describing how people shape ideas about acceptable and appropriate (linguistic and cultural) behavior.

My third hope is that this dissertation will encourage social scientists interested in issues of belonging to refocus their attention from perceived national centers to examining national debates of belonging and 'identity' in so-called peripheral areas. In regions outside perceived power centers, such as Limburg, language and cultural practices may contribute substantially to an awareness of local particularity and may be used to comment on national established social and political relations (Cornips et al. 2012). Hence, the study of local manifestations of belonging through language practices is needed in order to understand how politics of (un)belonging evolves in daily situations, practices, and encounters.

\section{Recommendations for society}

With this dissertation, I hope to have contributed to an understanding of how people deal with each other in contemporary societies undergoing globalization processes. The study of language practices proved to be essential in obtaining insights into how people appropriate places around them and shape feelings of and ideas about who or what behavior is considered in place and out of place within everyday interactions with others. These insights inform about social relations and existing ideas and perceptions in current societies, which should be regarded, in my view, as a thermometer for social cohesion and societal health.

First, this book has revealed the insight that the use of dialect is not confined to socalled 'native-born' Limburgers. This is an important observation for speakers of minority languages within as well as outside of Europe. People tend to make strong connections between minority and regional languages and particular provinces, regions, cities, and villages, where speakers of minority languages are expected to have lived for generations, engaging in local traditions and rituals, and/or having a particular appearance. Yet the research cases in this book have shown that this may not be the case and that we should adopt a more inclusive and multiplex understanding of language practices. As such, dialect 
speakers in Limburg do not all look a certain way or come from a fixed background and do not necessarily engage in local traditions or rituals.

Hopefully, these research cases have made people realize that language is powerful in people's construction of place attachments and social relations. Questioning or ignoring one's languaging potential may thus be a painful experience for speakers who have acquired particular linguistic forms, such as those associated with dialects. It would be better to openly ask whether a person speaks a particular language or dialect or at least understands it rather than ignoring someone's linguistic potential from the onset.

Secondly, this book aims to raise societal awareness within the Netherlands - but also elsewhere - that the current preoccupation with categories of people is misplaced and that, instead, it would be better to assume that people themselves relate in dynamic ways to such categories and labels through their language practices, place-making processes, and politics of (un)belonging. In that sense, this research follows the same line as Brubaker (2002), who argued against the tendency of groupism, which takes ethnicity and background as a starting point and, hence, reduces people to one category or label.

Importantly, this dissertation has illustrated the inapplicability of terms such as autochtoon, allochtoon, 'native,' and 'non-native' to describe what is going on in Dutch society by showing how daily language practices help to construct multi-layered, complex, and even contradictory place-making processes and politics of (un)belonging. Labels such as autochtoon, allochtoon, 'native,' 'non-native' do not provide any added value about the person to whom the label is applied. As pointed out by Yanow and Van der Haar (2013), the term autochtoon eliminates diversity among so-called 'natives' and lumps together inhabitants from all of the Netherlands' provinces, as if there were no regional differences. But this dissertation has shown that the construction of (un)belonging and place-making relies on a variety of societal scales or levels: local, regional, national, and global. The research cases have shown that similar processes are to be found in different contexts. UItimately, it becomes clear that the banal splits of opposing categories, such as autochtoon and allochtoon or 'native' and 'non-native,' are much more nuanced when taking an emic and practice-based approach.

Obviously, we will probably always use labels to make sense of the world around us and to call a spade a spade. Yet we should constantly question ourselves, realizing that labels are just labels and that we should understand their 'content' as much more plural and inclusive. Even people regarded as autochtoon may very well feel allochtoon or 'non-native' within their 'own' country, as the interaction between the two men in the city center of Roermond revealed. If the members of the carnival association were to take their carnival celebration to the Randstad area of the Netherlands, they would similarly feel allochtoon within their 'own' country. In contrast, staff members in the supermarket, who are perceived as allochtoon or 'non-native,' tried to find commonalities based on their foreignness, yet, on the other hand, they also negotiated and challenged each other's Dutch 'nativeness' when deciding which linguistic and cultural forms were deemed vital for legitimate claims to 'Dutchness' as well as foreignness.

It is for this reason that this book has coined the term foreignness, a concept that aims to let go of presupposed links with ethnicity, gender, class, culture, language, religion, etc. Foreignness refers to people's feelings of unbelonging in a particular place yet, at the same time, belonging with others who are also considered as unbelonging within that place. Where the general Dutch discourse departs from the opposition between autochtonen and allochtonen, this study of everyday practices, interactions, and encounters shows 
how any person at any time and in any context may feel out of place or foreign, feelings that may result in a shared feeling of sameness or belonging among those who feel out of place in one place yet simultaneously feel in place when they are together. As such, the concept of foreignness problematizes the Dutch discourse that is split into categories of autochtonen and allochtonen and strongly encourages Dutch society to be critical of the labels and categorizations we use and their effect on people.

Third, this dissertation has stressed the added value of ethnographic research and the rich insights that these methods may yield. As such, my hope is that policy makers will be encouraged, after reading this dissertation, to include more ethnographic studies and insights into their policy-making processes. Moreover, this book has stressed the importance of including people's language practices in social policy-making, since language use informs how people look at themselves and others at different levels of society (international, national, regional, and local) and which places become and remain important to them in their daily activities.

\section{Suggestions for future research}

While finishing this dissertation, a woman I met from South America told me that she felt excluded in Limburg: "When they talk to each other in dialect, it is all very well. Then they turn to me [moving her body directly at me], and they stare intensely at me while talking very loud Dutch. This is not at all inviting." Her statement and, even more so, her body movements made me wonder about the intertwining of body language with language practices and the effect that the body has on a person's feeling of belonging and, just as important, unbelonging.

Inspired by the woman's experience and based on my own daily encounters and realization of how others generally perceive me as 'the other' (see Chapter 1), it would be interesting to take this current research a step further and to come up with a holistic approach that considers not only the role of language, but also the role of bodies, perceptions of 'race,' and places on how people relate, perceive, include and exclude each other. For this, a combination of ethnographic and ethnomethodological methods would be valuable in obtaining insights into the daily experiences of inclusion and exclusion of different people within different places. Such research would provide insights into how people perceive 'race' and appearance, as was the case when the people in this research approached and talked to me within the carnival association, on Munsterplein plaza, and within the supermarket.

\section{Talking in and out of place}

The guiding question of this book was how people give meaning to the places they inhabit by engaging in language practices with others. I have shown that language practices produce place-making processes that attach ideas of who or what behavior is considered in and out of place. On the basis of these ideas, people engage in politics of (un)belonging in which they negotiate not only their own feelings of belonging and unbelonging, but also those of others. Moreover, the coined concept of foreignness suggests that anyone may, at some point, feel out of place, feelings that at the same time render feelings of belonging 
through unbelonging with others who share the same feelings and experiences. Language practices and ideologies turned out to be vital in the justifications of these politics of (un) belonging. As such, this book showed that daily and seemingly insignificant interactions between people can teach us a great deal about the ways that we deal with each other and how we continuously draw boundaries between 'us' and 'them,' thereby defining and giving meaning to the places around us.

I chose to title this book Talking in and out of place to reflect two dimensions of talk. On the one hand, people may explicitly discuss who or what behavior they perceive as being in and out of place. On the other hand, these ideas of who or what behavior is in and out of place may be deduced from people's use of particular linguistic and cultural forms. As such, the title reflects how people, through their language practices, reveal their own individual feelings of being in or out of place while they also reveal ideas about whether others belong to a place or not. By examining these two dimensions of talk - the explicit discussions on belonging as well as the language ideologies that inform who or what behavior people perceive appropriate or not - this dissertation analyzed how people engage in talking in and out of place. 


\section{Appendix A - Introduction of research in De Katers carnival association's magazine in 2012-2013}

\section{Veer gaon allemaol antropologie sjtudere!!}

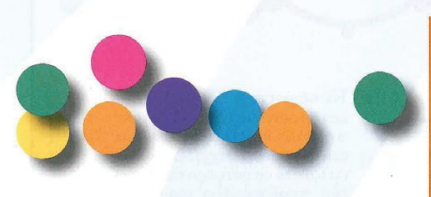

De leje van de Raod van Ellef zeen 't d'r helemaol euver ins. Dit is de toekóms, dit haet toekóms en dit wille veer allemaol gaer in de toekóms gaon doon! Waat meint dae noe zólt geer uch aafvraoge: Nou, ich zal uch det ins efkes haorfien oetlegke!

Sins dunellefdevandunellefde löp d'r bie de Katers ein "sjtazjaere" róndj. Zie hit Lotte en is bie eder aktiviteit van de Katers dit sezoen te zeen, gewaopend mit sjriefblökske, opnaemapperaat en fototoesjtel. Lotte is ein leuke meid die aafgesjtudeerd is es antropologe en het duit noe ein sjtudie óm doctor in de antropologie te waere.

Op de vraog van de redaksie van waat 't ein en anger inheel, krege veer ein kort en bónjig antjwaord (in 't plat!):

\section{veer sitere:}

- Mien promosie-óngerzeuk geit in op de vraog wie miense beteikenis gaeve aan een plek (in dit geval de gemeinte Remunj) door middel van taal en kultuur. Ich óngerzeuk dit mit de antropologiese metode, waat inhilt det ich partisiperend óngerzeuk verricht veur langere periodes bie bepaolde groepe en plekke. De Katers oet Neel is ein van de groepe die ich betrek biej mien óngerzeuk ómdet ich ge-interesseerd bön

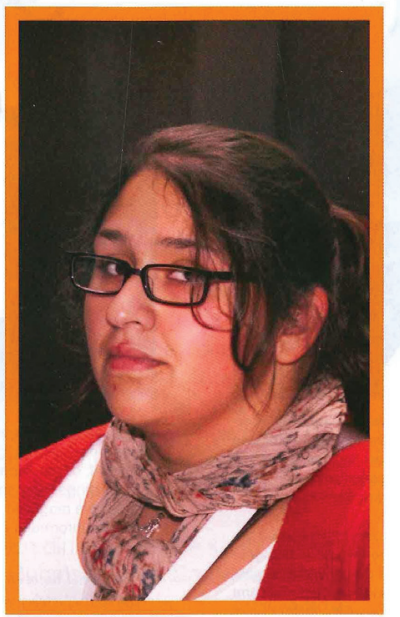

in de menere wie taal en kultuur ingezat waere gedoerende de Vastelaovend en wie dit gebeurd in ein plek wie Neel. Ich höb veur De Katers gekaoze vanwaege de gesjiedenis van Neel binne Remunj en ich wil kieke wie die gesjiedenis en eige identiteit zich in taal en kultureel manifesteert binne de Vastelaovend. -

Toet zover 't sitaat.

Noe höbbe veer es redaksie van KlassjeNeel netuurlik de opgaaf óm uch dudelik te make waat deze doctor in sjpee, in Neelse-MienseTaal bedoelt.

Bie deze ein vrieje vertaling van waat hiebaove sjteit:

Vraogsjtelling: beteikenis gaeve aan Remunj door middel van taal en kultuur:

- Waat vinje veer es Neelder van
Remunj en wie kinne veer die van d'n Uul op ós eige meneer ein oor aanneije bieveurbeeldj tiedes de Bóntje Aovende

\section{Antropologiese metode:}

- partisiperend óngerzeuk: d'rbie zeen! Mit feeste, mit drinke, mit sjpringe, genete van de äöpening, 't jubelejum, Leedjesfestival, Bóntje Aovende en nog väöl meer, en det neet allein bie de Katers mer ouch nog bie angere

\section{Gesjiedenis Neel binne Remunj}

- Hiej mótte veer de aansjtaonde doctor nog efkes op ein nuwanse-versjil wieze. 't Is Remunj waat zich Neel haet ingepik, mit loepetige óngersjteuning van de toenmalig regering, die daomit de basis veur her-indeiling lag.

\section{Eige identiteit binne de} vastelaovend

- 't Moog dudelik zeen det "Neel blief Neel" dao ein gooj uting van is, en 't alles-ómvattende en enig juuste antjwaord.

Dit liek ós veurluipig waal meer es genóg oetlègk.

Dit is netuurlik kaasje veur ederein van de Raod van Ellef, veural det "partisiperend óngerzeuk" haet ós biezunjere belangsjtelling! Veer dinke det Neel wederom ein biedrage kint levere aan de geleerdheid! Veer winse Lotte väöl suukses en zeen det proofsjrif mit belangsjtelling kómme.

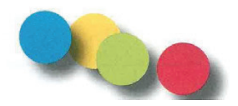


English translation of the text:

\section{We are all going to study anthropology!!}

The members of the council of eleven all agree. This is the future, this has perspective and we all want to do this in the future! What is he talking about, you will think: well, I will explain it in great detail to you!

Since the ' $11^{\text {th }}$ of the $11^{\text {th' }}$ (November 11), an 'intern' has joined De Katers. Her name is Lotte, and she will be present during each activity of De Katers, equipped with notebook, recording device, and photo camera. Lotte is a nice girl who graduated as an anthropologist and is currently doing a study to become a doctor in anthropology. To the question of the editors what this exactly entails, we obtained a brief answer (in plat!):

\section{We cite:}

- My Ph.D. research deals with the question of how people give meaning to a location (in this case the municipality of Roermond) by means of language and culture. I examine this through anthropological methods, which means I am doing participant observational research for a longer period of time among particular groups and locations. De Katers from Neel is one of the different groups that I include in my research because I am interested in the ways that language and culture are used during carnival and how this happens in a location such as Neel. I have chosen De Katers due to the history of Neel within Roermond, and I want to find out how the history and local identity manifest itself within carnival. -

So far the citation.

Now it is our task as editors of KlassjeNeel to make clear what this future doctor means in Neels-People-Language.

Hereby a free translation of what is mentioned above:

\section{Question:}

- What do we, as Neelder people, think about Roermond and how can we, in our own style, take $D^{\prime} n$ Uul for a ride, for example during a Theater Night.

\section{Antropological method:}

- participant research: to get involved! Party along, drink along, jump along, enjoy the opening, the anniversary, the song festival, the theater nights, and so on. And all this not only with De Katers, but also with others.

\section{History of Neel within Roermond}

- It is here where we have to point the future doctor to a nuance. It is Roermond who grabbed Neel with the contriving help of the then [national] government, which thereby founded the basis for the municipal re-division.

\section{Local identity with carnival}

- Clearly, 'Neel blief Neel' is a good example of this and it is the complete and only correct answer. 
We believe this is more than enough explanation for now.

Obviously, this is a walk in the park for everyone in the council of eleven, we are keen on the 'participant research' part! We think that Neel can contribute to science once more! We wish Lotte good luck and are very much looking forward to her dissertation. 


\section{Appendix B - Schedule of De Katers carnival association for the 2012-2013 season}

The following scheme displays the busy schedule of De Katers' 2012-2013 season. What becomes clear is how busy a carnival association's season can be. Except for the Dutch denominators dag (day), datum (date), activiteit (activity), locatie vertrek (location of departure), aanvang (start), and aanwezig (present at hour), days, events, and descriptions are written in a mix of linguistic forms associated with Dutch and dialect.

\begin{tabular}{|c|c|c|c|c|c|}
\hline Dag & Datum & Activiteit & Locatie vertrek & Aanvang & Aanwezig \\
\hline Woonsdig & 2-jan & 1e Rippetisie Bonte Aovend mit Kombo & De Ster & 19.30 oer & \\
\hline Vriedig & 4-jan & Opboewe veur Dance Event Neel & De Ster & 11.00 oer & \\
\hline Vriedig & 4-jan & 16+ Dance Event Neel & De Ster & 20.00 oer & 19.00 oer \\
\hline Zaoterdig & 5-jan & Ophalen materialen oppe Baekwaeg & & 10.00 oer & \\
\hline Zaoterdig & 5-jan & Zaal versieren voor Jeugprins uitroepen & 't Dörp & 10.00 oer & \\
\hline Zunjig & 6-jan & Foto's maken veur Klasjeneel, foto aanbeje & 't Dörp & 13.30 oer & 13.15 oer \\
\hline Zunjig & 6-jan & Jeugdprins uitroepen middag & 't Dörp & 14.11 oer & aansjloetend \\
\hline Dinsdig & 8-jan & Rommel ripetisie 2 Bonte Aovond & De Ster & 19.30 oer & \\
\hline Vriejdig & 11-jan & Rippetisie KBM & De Ster & 16.00 oer & \\
\hline Zaoterdig & 12-jan & Opbouwen Bonte avond/materialen ophalen & De Ster & 10.00 oer & \\
\hline Zaoterdig & 12-jan & Klassjeneel verkoup + Vlagge-aktie & In gans Neel & 10.00 oer & \\
\hline Zaoterdig & 12-jan & Resepsie VV De Haofgengers & De Ster & 18.30 oer & 17.45 oer \\
\hline Zaoterdig & 12-jan & Bezoek cafe de Thooren raad en kepel + foto & Thooren & & aansjloetend \\
\hline Zunjig & 13-jan & Klassjeneel verkoup + Vlagge-aktie & In gans Neel & 10.00 oer & \\
\hline Zunjig & 13-jan & Jeugprinsenresepsie Haofgengers & 't Dörp & 15.30 oer & 14.45 oer \\
\hline Zunjig & 13-jan & Resepsie VV De Waterratte & De Ster & 16.00 oer & 15.00 oer \\
\hline Woonsdig & $? ?$ & Tent opbouwen/Zaal inrichten t.b.v. Bonte Avond & De Ster & 19.00 oer & \\
\hline Woonsdig & 16-jan & Generale repetitie Bonte Avond & De Ster & 19.30 oer & \\
\hline Vriedig & 18-jan & Euverdaag opbouwen Bonte aovond & De Ster & 11.00 oer & \\
\hline Vriedig & 18-jan & Rippetisie KBM & De Ster & 16.00 oer & \\
\hline Vriedig & 18-jan & Bonte aovond & De Ster & 20.00 oer & 19.30 oer \\
\hline Zaoterdig & 19-jan & Zaal weer in orde voor Bonte aovond & De Ster & 11.00 oer & \\
\hline Zaoterdig & 19-jan & Jeugdprinseresepsie Donderböl & De Ster & 17.30 oer & 16.45 oer \\
\hline Zaoterdig & 19-jan & Resepsie VV Koelbertus & De Ster & 19.00 uur & 18.15 oer \\
\hline Zoaterdig & 19-jan & Bonte Aovond & De Ster & 20.00 oer & 19.30 oer \\
\hline Zunjig & 20-jan & Zaal weer in orde voor Bonte middig & De Ster & 10.00 oer & \\
\hline Zunjig & 20-jan & Bonte middig & De Ster & 14.00 oer & 13.30 oer \\
\hline Zunjig & 20-jan & Jeugdprinsenresepsie Koelbertus (Sjoolpaad) & 't Dörp & 15.30 oer & 14.45 oer \\
\hline Zunjig & 20-jan & Resepsie VV De Donderböl & & 18.00 oer & aansjloetend \\
\hline Zunjig & 20-jan & Zaal opruimen en afvoeren materialen & De Ster & 19.00 oer & \\
\hline Vriedig & 25-jan & Generale KBM & De Ster & 16.00 uur & \\
\hline Vriedig & 25-jan & Veer Vief gaon veur goud & 't Dörp & 20.11 oer & 20.00 oer \\
\hline
\end{tabular}




\begin{tabular}{|c|c|c|c|c|c|}
\hline Zaoterdig & 26-jan & Opboewe veur KBM & De Ster & 10.00 oer & \\
\hline Zaoterdig & 26-jan & Jeugdprinsenresepsie De Kitsuule & & 16.00 oer & 15.15 oer \\
\hline Zunjig & 27-jan & Resepsie VV De Tuinhagedisse & De Ster & 12.30 oer & 11.45 oer \\
\hline Zunjig & 27-jan & Jeugdprinsenresepsie De Veldjmuus & & 13.15 oer & 12.30 oer \\
\hline Zunjig & 27-jan & KBM & De Ster & 14.11 oer & aansjloetend \\
\hline Zunjig & 27-jan & Jeugdprinseresepsie D'n Uul & & 17.30 oer & aansjloetend \\
\hline Zunjig & 27-jan & Opruimen zaal na KBM & De Ster & 19.00 oer & \\
\hline Donderdig & 31-jan & Bezoek avond Pappelhof in de Soos & De Ster & 20.00 oer & 19.30 oer \\
\hline Vriedig & 1-feb & LVK & Sporthal & & \\
\hline Zaoterdig & 2 -feb & Zaal in orde voor PNO & De Ster & 11.00 oer & \\
\hline Zaoterdig & 2 -feb & Stadswandeling grote Prinsen SRV & Stad & 9.30 oer & \\
\hline Zaoterdig & 2 -feb & Foto's maken prinsen Trompetter & Velderie & 12.30 oer & \\
\hline Zaoterdig & 2 -feb & Jeug-prinsse-treffe (De Vlonder) & 't Dörp & 13.00 oer & 12.30 oer \\
\hline Zaoterdig & 2 -feb & Vastelaovesmis & Kirk & 18.00 oer & 17.45 oer \\
\hline Zaoterdig & 2 -feb & Resepsie VV De Kitsuule & & 19.30 oer & aansjloetend \\
\hline Zaoterdig & 2 -feb & Prins Neudig Oet mit vereniginge oet Neel & De Ster & 20.30 oer & aansjloetend \\
\hline Zunjig & 3-feb & Zaal opbouwen voor resepsie jeugdprins & 't Dörp & 11.00 oer & \\
\hline Zunjig & 3-feb & Resepsie VV De Veldjmuus & De Ster & 13.00 oer & 12.15 oer \\
\hline Zunjig & 3-feb & Jeugdprinsenresepsie De Katers & 't Dörp & 14.11 oer & aansjloetend \\
\hline Zunjig & 3-feb & Koffietafel Prins & De Ster & 18.30 oer & aansjloetend \\
\hline Maandag & 4-feb & Ophaole Prinsewage in Velden & & & \\
\hline Maandag & 4-feb & Remunjse zaken / Alternatief in Kitsuule te Kitskensberg & De Ster & 20.00 oer & 19.30 oer \\
\hline Dinsdig & $5-f e b$ & Prinssentreffen Oranjerie & De Oranjerie & 20.00 oer & 19.15 oer \\
\hline Donderdig & 7-feb & Bezoek prinsen aan Montessori school & & & \\
\hline Donderdig & 7-feb & Bezoek prins aan Roncalli & Roncalli & 14.00 oer & \\
\hline Donderdig & 7-feb & Prinse-aete biej De Sjligro & Sligro & & \\
\hline Donderdig & 7-feb & Kersediner & t Roerpötje & & \\
\hline Vriedig & 8-feb & Sjole-bezeuk & De Ster & 13.30 oer & 13.00 oer \\
\hline Vriedig & 8-feb & Brandjwaer-bal & Nautilus & 17.00 oer & aansjloetend \\
\hline Vriedig & 8-feb & Opening Neelder Garde & 't Dörp & 20.30 oer & 20.30 oer \\
\hline Zoaterdig & 9-feb & Sleuteloverdracht Stadhuis & De Ster & 10.00 oer & 9.30 oer \\
\hline Zaoterdig & 9-feb & Opbouwen voor resepsie en wagen & De Ster & 11.00 oer & \\
\hline Zaoterdig & 9-feb & Resepsie Prins VV De Katers & De Ster & 18.33 oer & 18.00 oer \\
\hline Zaoterdig & 9-feb & Gezamenlijk opruimen na afloop & De Ster & & \\
\hline Zunjig & $10-f e b$ & Resepsie VV De Nachtegale & & 11.30 oer & 10.45 oer \\
\hline Zunjig & $10-$ feb & Optocht in Neel & De Thooren & 14.11 oer & 13.30 oer \\
\hline Zunjig & $10-$ feb & Resepsie VV D'n Uul & Bus Boerenbond & 16.00 oer & 15.30 oer \\
\hline Zunjig & $10-f e b$ & Vastelaovend in de soos + uitreiken attentie & Soos & 17.33 oer & aansjloetend \\
\hline Zunjig & $10-$ feb & Priesoetreiking Optoch in de Ster & De Ster & 18.11 oer & aansjloetend \\
\hline
\end{tabular}




\begin{tabular}{|c|c|c|c|c|c|}
\hline Zunjig & $10-f e b$ & Resepsie VV De Kaketoes & Bus Boerenbond & 20.00 oer & 19.30 oer \\
\hline Zunjig & $10-$ feb & Avondprogramma in de Ster & De Ster & & aansjloetend \\
\hline Maondig & $11-f e b$ & Optocht stad & Stad & 13.11 oer & 12.00 oer \\
\hline Maondig & $11-f e b$ & Rundje Sjnaps & 't Dorp & 16.11 oer & aansjloetend \\
\hline Maondig & $11-f e b$ & Rundje Limenaad en vastelaovend & Soos & 16.11 oer & aansjloetend \\
\hline Maondig & $11-f e b$ & Bezoek Prins en kepel aan Rundje Limenaad & Soos & 17.30 oer & aansjloetend \\
\hline Maondig & $11-f e b$ & Avondprogramma in 't Dorp & t Dorp & 21.30 oer & aansjloetend \\
\hline Dinsdig & $12-f e b$ & Pijama-sjoppe mit artieste & t Dorp & 11.11 oer & zelf regelen \\
\hline Dinsdig & $12-f e b$ & Kienjer-optoch in de sjtad & t Dörp & 11.00 oer & zelf regelen \\
\hline Dinsdig & $12-f e b$ & Femilie-middig & De Ster & 14.11 oer & 13.30 oer \\
\hline Dinsdig & $12-f e b$ & Avondprogramma met aaftreje Prins & De Ster & 21.00 oer & 21.00 oer \\
\hline Woonsdig & $13-f e b$ & Opruimen & De Ster & 10.30 oer & \\
\hline Woonsdig & $13-f e b$ & Evaluatie Vorsten & & 11.11 oer & \\
\hline Woonsdig & $13-f e b$ & Assekruutske haole in de kerk & Kerk & & \\
\hline Woonsdig & $13-f e b$ & Heringsjelle & Ster + Dorp & 20.30 oer & \\
\hline Vriedig & $15-f e b$ & Aafraekene & De Ster & 20.00 oer & \\
\hline Woonsdig & $20-$ feb & Bestuursvergadering Evaluatie 2012/2013 & & 20.30 oer & \\
\hline \multirow[t]{4}{*}{ Vriedig } & $22-f e b$ & Kotsvergadering Raod van Elf & De Ster & 20.30 oer & \\
\hline & $? ?$ & Kotsvergadering Kepel & De Ster & 20.00 oer & \\
\hline & $? ?$ & Bonte Aovend Parelhoenders op Camilus & De Ster & & \\
\hline & ?? & Bezoek cafe de Pauw Raod en Kepel & De Pauw & & \\
\hline
\end{tabular}




\section{Appendix C - Interview with Rabobank}

In August 2012, the bank that supported Dost Market during its start-up phase, Rabobank, published an interview with the owners on how they started their supermarket.

\section{Dost Market, droom wordt werkelijkheid}

Dost Market is gevestigd in Winkelcentrum Donderberg in Roermond. Vennoten Ihsan Boztas (38), Seyithan Boztas (29) en Ismail Boztas (18) openden op 12 juni de deuren. De supermarkt is een multiculturele winkel met buitenlandse voedingsmiddelen. Ook worden er huishoud- en verzorgingsproducten verkocht en is er een slager aanwezig. Ihsan Boztas: "Ik had al jaren plannen om een supermarkt te starten. Het is een droom die is uitgekomen." Met twee broers en een neef is het een echt familiebedrijf. Een logische keuze vindt Seyithan Boztas: "Samen sta je gewoon sterker. Je vertrouwt elkaar al volledig." Naast de drie vennoten zijn er nog twee andere familieleden werkzaam in de supermarkt.

Voorafgaand aan de opening is er twee maanden verbouwd in het voormalige DA pand. Ihsan Boztas: "We hebben samen hard gewerkt om dit voor elkaar te krijgen. Direct vanaf de opening loopt de winkel goed. Met de opening wisten we gewoon niet wat we moesten doen, zo'n drukte en instroom van mensen. Dat terwijl we niets aan publiciteit hadden gedaan. En nu nog steeds niet. We hebben er simpelweg nog geen tijd voor gehad. Zonder partnership van de Rabobank waren we niet zo ver gekomen. Onze adviseur Malika Benameur had blindelings vertrouwen in onze formule.

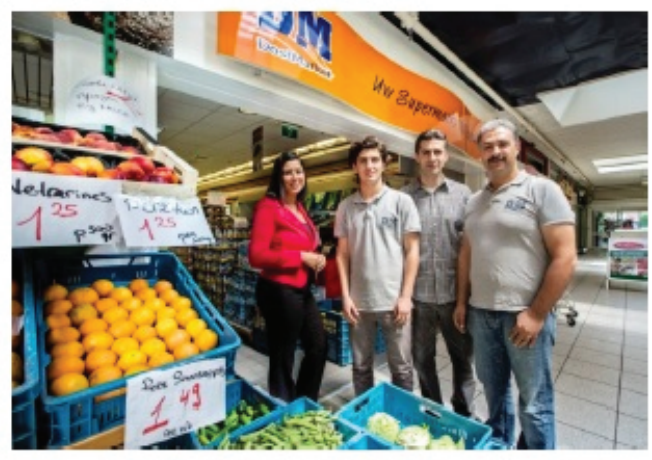
Ze staat ons altijd te woord en maakt tijd voor ons vrij."

Dost Market is voor iedereen toegankelijk. Seyithan: "Ondanks dat het assortiment is gericht op onder andere Turkse, Bosnische en Marokkaanse bevolkingsgroepen, zijn we positief verrast door het aantal Nederlandse klanten." Persoonlijk contact staat hoog in het vaandel. Ihsan vertelt: "Dagelijks ontvangen we een 10 à 15 nieuwe klanten. Met de klanten die ik nog niet ken, maak ik een praatje en ik verwelkom ze. Het geeft me een goed gevoel dat klanten blijven terugkomen met positieve reacties. Dat bewijst dat ons plan tot nu toe is gelukt. Het is overigens pas een begin, het moet steeds beter en beter worden. Als je iedere dag harder werkt dan de dag ervoor, dan kom je er wel."

Het assortiment wordt met zorg samengesteld. Seyithan Boztas: "We passen het assortiment aan de wensen van onze klanten aan. We hadden niet meteen alle producten in voorraad. Als klanten naar iets vragen, doen wij ons best om het op te nemen in ons assortiment. Daardoor hebben we nu meer diversiteit dan vooraf verwacht."

Dat klantbelang voorop staat blijkt ook uit de verbouwing die op het einde van het jaar op de planning staat. Ihsan Boztas: "De ingang komt op een andere plek waardoor de indeling efficiënter wordt. Ook wordt er ruimte gemaakt voor een extra kassa zodat klanten niet lang hoeven te wachten."

Foto: Malika Benameur, bedrijvenadviseur van Rabobank Roermond-Echt, samen met vennoot Ihsan Boztas (rechts), vennoot Seyithan Boztas (links van Ihsan) en medewerker Umit Boztas. 
English translation of the text:

Dost Market is located in Donderberg Shopping Mall in Roermond. Shareholders Ihsan Boztas (38), Seyithan Boztas (29), and Ismail Boztas (18) opened their doors on June 12 [2012]. The supermarket is a multicultural shop with foreign food articles. Moreover, household and cosmetic products are sold and there is a butchery. Ihsan Boztas: "For years I had plans to start a supermarket. It is a dream come true." With two brothers and a cousin, this supermarket is a real family business. A logical choice, according to Seyithan Boztas: "Together you stand strong. You already trust each other completely." Besides the three shareholders, two other family members work in the supermarket.

Prior to the opening, they rebuilt the former building of DA [a drugstore] for two months. Insan Boztas: "We worked hard to get this done together. From the start, the store is doing well. During the opening, we simply didn't know what to do, such a rush and influx of people. Even though we didn't advertise at all, and still we haven't. We simply don't have the time. Without the partnership of Rabobank, we wouldn't have come this far. Our advisor, Malika Benameur, trusted our formula blindly. She always responds and makes time for us."

Dost Market is accessible to everyone. Seyithan: "Although the assortment is directed at, among others, Turkish, Bosnian, and Moroccan population groups, we are positively surprised by the number of Dutch customers." Personal contact is high on the agenda. Ihsan recounts: "Every day we welcome 10 to 15 new customers. I talk to the customers I don't know yet and welcome them. It makes me feel good when customers return with positive reactions. It proves that our plan worked out up until now. It is only just a start, it has to become better and better. If each day you work harder than yesterday, then you'll work it out."

The assortment is carefully composed. Seyithan Boztas: "We adapt the assortment to our customers' wishes. At first, we didn't have all products in stock. When customers ask for something, we try our best to make it part of our assortment. This is why we have more diversity now than we expected at first."

The renovation that is planned for the end of the year also proves that customers' needs are highly valued. Ihsan Boztas: "The entrance will be replaced, which will make the interior more efficient. Moreover, we will create space for an extra cash desk, so that customers won't have to wait long."

Photo: Malika Benameur, business advisor Rabobank Roermond-Echt together with shareholder Ihsan Boztas (on the right), shareholder Seyithan Boztas (to the left of Ihsan) and employee Umit Boztas. 


\section{Bibliography}

\section{Books, chapters, and articles}

Agha, Asif

2007 Language and Social Relations. Cambridge: Cambridge University Press.

2008 Register. Journal of Linguistic Anthropology 9(1):216-219.

Ahearn, Laura M.

$2001 \quad$ Language and Agency. Annual Review of Anthropology 30:109-137.

2012 Living Language: An Introduction to Linguistic Anthropology. Malden: Wiley-Blackwell.

Alborn, Timothy

2001 Senses of Belonging: The Politics of Working-class Insurance in Britain, 1880-1914.

The Journal of Modern History 17(3):561-602.

Alim, H. Samy, John R. Rickford, and Arnetha F. Ball

2016 Raciolinguistics: How Language Shapes Our Ideas About Race. Cary/New York: Oxford University Press.

American Anthropological Association

2012 Principles of Professional Responsibility. http://ethics.aaanet.org/category/statement/, accessed April 2, 2015.

Amin, Ash

2002 Spatialities of Globalisation. Environment and Planning 34:385-399.

Anderson, Benedict

1983 Imagined Communities: Reflections on the Origin and Spread of Nationalism. London Verso.

Ang, len

1994 On Not Speaking Chinese: Postmodern Ethnicity and the Politics of Diaspora. New Formations 24:1-18.

Ang, len and Jon Stratton

1996 Asianing Australia: Notes toward a Critical Transnationalism in Cultural Studies.

Cultural Studies 10(1):16-36.

Anthias, Floya

2002 Where Do I Belong? Narrating Collective Identity and Translocational Positionality. Ethnicities 2(4):491-514.

Antonsich, Marco

2010 Searching for Belonging - An Analytical Framework. Geography Compass 4(6):644-659.

Appel, René

1999 Straattaal: De mengtaal van jongeren in Amsterdam. Toegepaste Taalwetenschap 62(1):39 -55.

Averill, Gage

1994 Anraje to Angaje: Carnival Politics and Music in Haiti. Ethnomusicology 38(2):217-247.

Bakhtin, Mikhail

1984 [1929] Problems of Dostoevsky's Poetics. Caryl Emerson, trans. Minneapolis: University of Minnesota Press.

Balkenhol, Markus

2015 Zwarte Piet, racisme, emoties. Waardenwerk 62/63:36-46.

Barrett, Stanley R.

2002 [1996] Anthropology: A Student's Guide to Theory and Method. Toronto: University of Toronto Press. 
Barth, Fredrik

1969 Ethnic Groups and Boundaries: The Social Organization of Culture Difference.

Oslo: Universitetsforlaget.

Bauman, Richard

1992 Contextualization, Tradition, and the Dialogue of Genres: Icelandic Legends of the Kraftaskáld. In Rethinking Context: Language as an Interactive Phenomenon. A. Duranti and C. Goodwin, eds. Pp. 125-45. Cambridge: Cambridge University Press.

Bauman, Zygmunt

1998 Globalization: The Human Consequences. Cambridge: Polity Press.

\section{Beatley, Timothy}

2004 Native to Nowhere: Sustaining Home and Community in a Global Age. Washington, DC: Island Press.

Becker, Howard S.

1998 Tricks of the Trade: How to Think about Your Research while You're Doing It. Chicago: The University of Chicago Press.

Beckers, Theo

2006 De kwestie Maasniel: strijd om eigen identiteit. Utrecht: uitgeverij Matrijs.

Bennis, Hans, Guus Extra, Pieter Muysken and Jacomine Nortier

2002 Een buurt in beweging. Talen en culturen in het Utrechtse Lombok en Transvaal. Amsterdam: Uitgeverij Aksant.

\section{Bergeaud-Blackler, Florence}

2006 Halal: d'une norme communautaire à une norme institutionnelle. Journal des antropologues 106-107:73-103.

Bernard, Russel H.

1995 Research Methods in Anthropology: Qualitative and Quantitative Methods. Walnut Creek: Altamira Press.

Bhamra, Gurminder

2006 Culture, Identity, and Rights: Challenging Contemporary Discourses of Belonging. In The Situated Politics of Belonging. N. Yuval-Davis, K. Kannabiran, U. Vieten, eds. Pp. 32-41 London/Thousands Oaks, CA/New Dehli: Sage Publications.

Bienia, Rafael

2016 Role Playing Materials. Ph.D. dissertation. Braunschweig: Zauberfeder Verlag.

Black, Rachel E.

2012 Porta Palazzo: The Anthropology of an Italian Market. Philadelphia: University of Pennsylvania Press.

Blumer, Herbert

1954 What is Wrong with Social Theory? American Sociological Review 18:3-10.

Blok, Anton

1976 Wittgenstein en Elias. Amsterdam: Athenaeum - Polak \& Van Gennep.

Blommaert, Jan

2010 The Sociolinguistics of Globalization. Cambridge: Cambridge University Press.

2013 Ethnography, Superdiversity and Linguistic Landscapes: Chronicles of Complexity. Bristol:

Multilingual Matters.

Blommaert, Jan and Piia Varis

2011 Enough is Enough: The Heuristics of Authenticity in Superdiversity. Tilburg Papers in Culture Studies:2. 
Boon, Lex

2011 Wilders tegen Rutte: doe eens normaal man. NRC Handelsblad, September 22. https:// www.nrc.nl/nieuws/2011/09/22/wilders-tegen-rutte-doe-eens-normaal-man-a1452582, accessed May 23, 2017.

Bourdieu, Pierre

1990 The Logic of Practice. Stanford: Stanford University Press. [Translated by Richard Nice]. 1991 Language and Symbolic Power. Cambridge: Harvard University Press. [Gino Raymond and Matthew Adamson].

Brewer, John D.

$2000 \quad$ Ethnography. New York: McGrawHill.

Broeder, Peter and Guus Extra

1996 Minderheidsgroepen en minderheidstalen in vergelijkend perspectief. Gramma/TTT,

Tijdschrift voor taalwetenschap 5(2):77-97.

Brubaker, Rogers

2002 Ethnicity without Groups. European Journal of Sociology 43(2):163-189.

Brubaker, Rogers and Frederick Cooper

2000 Beyond "Identity"'. Theory and Society 29:1-47.

Bucholtz, Mary

1999 'Why Be Normal?': Language and Identity Practices in a Community of Nerd Girls', Language in Society 28(2): 203-23.

2000 The Politics of Transcription. Journal of Pragmatics 32(10):1439-1465.

Bucholtz, Mary and Kira Hall

2004 Language and Identity. In A Companion to Linguistic Anthropology.

A. Duranti, ed. Pp. 369-394. Hoboken: Wiley-Blackwell.

2005 Identity and Interaction: A Sociocultural Linguistic Approach. Discourse Studies 7(4-5):585-614.

2016 Embodied Sociolinguistics. In Sociolinguistics: Theoretical Debates. N. Coupland, ed. Pp.

173-199. Cambridge: Cambridge University Press.

Centraal Bureau voor de Statistiek (CBS)

$2000 \quad$ Allochtonen in Nederland. Voorburg: Centraal Bureau voor de Statistiek.

2009 Religie aan het begin van de 21e eeuw. Den Haag: Centraal Bureau voor de Statistiek.

2011 Gemeente op maat: Roermond. Den Haag/Heerlen: CBS.

2016 Bevolkingsontwikkeling regio per maand, Limburg.

http://statline.cbs.nl/Statweb/publication/?DM =SLNL\&PA=37230ned\&D1=0,17\&D2=16,53-

55\&D3=182-194\&VW=T, accessed February 1, 2017.

Chambers, Jack, and Peter Trudgill

1980 Dialectology. Cambridge: Cambridge University Press.

\section{Charmaz, Kathy}

2003 Grounded Theory: Objectivist and Constructivist Methods. In Strategies for Qualitative Inquiry. N.K. Denzin and Y.S. Lincoln, eds. Pp. 249-291. Thousand Oaks, CA: Sage.

\section{Christensen, Ann-Dorte}

2009 Belonging and Unbelonging from an Intersectional Perspective. Gender, Technology and Development 13(21):21-41

Clifford, James and George E. Marcus

1986 Writing Culture: The Poetics and Politics of Ethnography. Berkeley: University of California Press.

Collins, Jock, Katherine Gibson, Caroline Alcorso, Stephen Castles, David Tait

1995 A Shop Full of Dreams: Ethnic Small Business in Australia. Melbourne: Pluto Press Australia. 


\section{Corbin, Juliet and Anselm Strauss}

1990 Grounded Theory Research: Procedures, Canons, and Evaluative Criteria.

Qualitative Sociology 13:3-21.

\section{Cornips, Leonie}

2008 Loosing Grammatical Gender in Dutch. The Result of Bilingual Acquisition and/or an Act of Identity. International Journal of Bilingualism 12(1-2):105-124.

2012 Carnaval en Sinterklaas. Dagblad de Limburger/Limburgs Dagblad, December 8, http://fasos.maastrichtuniversity.nl/profiles/Cornips/Column\%206\%20\%20Sinterklaas\%20 en\%20carnaval.pdf, accessed July 23, 2014.

2013 Taalcultuur: Talen in Beweging. Taal \& Tongval 65(2): 125-147.

2014 Ondertiteling. Dagblad de Limburger/Limburgs Dagblad, March 222014.

https://www.meertens.knaw.nl/cms/images/Oratie\%20Cornips/ondertiteling.pdf. in press Social Meanings of the North-south Divides in the Netherlands and Limburg and Their Linkage to Standard Dutch and Dialect Varieties. In Language Variation and Change: Regard and Contact. B. E. Evans, E. Benson, and J. Stanford, eds. Pp. [...] Cambridge: Cambridge University Press.

\section{Cornips, Leonie and Frans Gregersen}

2016 The Impact of Labov's Contribution to General Linguistic Theory. Journal of Sociolinguistics 20(4):498-524.

\section{Cornips, Leonie and Ad Knotter}

2016 De uitvinding van Limburg: de territorialisering van geschiedenis, taal en identiteit. In Studies over de Sociaal-Economische Geschiedenis van Limburg. Jaarboek Sociaal Historisch Centrum voor Limburg, volume LXI: 136-163. A. Knotter and W. Rutten, eds. Pp. 136-163. Maastricht: Sociaal Historisch Centrum voor Limburg

\section{Cornips, Leonie and Vincent de Rooij}

2015 Belonging through Languagecultural Practices in the Periphery. The Politics of Carnival in the Dutch Province of Limburg. Anthropological Journal of European Cultures 24(1):83-101.

2013 Selfing and Othering through Categories of Race, Place, and Language Among Minority Youths in Rotterdam, The Netherlands. In Multilingualism and Language Diversity in Urban Areas. P. Siemund, I. Gogolin, M.E. Schulz, and J. Davydova, eds. Pp. 129-164. Amsterdam: John Benjamins.

Cornips, Leonie and Vincent de Rooij, eds.

2018 The Sociolinguistics of Place and Belonging: Perspectives from the Margins. Amsterdam: John Benjamins.

Cornips, Leonie, Vincent de Rooij, and Irene Stengs

2012 Carnavalesk taalgebruik en de constructie van lokale identiteiten. Een pleidooi voor taalcultuur als onderzoeksveld. Dutch Journal of Applied Linguistics 1(1): 15-40.

Cornips, Leonie, Vincent de Rooij, Irene Stengs, and Lotte Thissen

2016 Dialect and Local Media: Reproducing the Multi-dialectal Hierarchical Space in Limburg (the Netherlands). In Standard Language Ideology in Contemporary Europe (SLICE) volume 3:

Style, Media and Language Ideologies. J. Thøgersen, N. Coupland, and J. Mortensen, eds. Pp. 189-216. Oslo: Novus Press.

\section{Council of Europe}

1999 Implementation of the European Charter for Regional and Minority Languages. Regional and Minority Languages 2. Strasbourg: Council of Europe Publishing.

\section{Coupland, Nicolas}

2003 Sociolinguistic Authenticities. Journal of Sociolinguistics 7(3):417-431. 
Cresswell, Tim

1996 In Place/Out of Place: Geography, Ideology, and Transgression. Minneapolis/London:

University of Minnesota Press.

2009 Place. In International Encyclopedia of Human Geography, Volume 8. R. Kitchin and

N. Thrift, eds. Pp. 169-177. Oxford: Elsevier.

Crowley, John

1999 The Politics of Belonging: Some Theoretical Considerations. In The Politics of Belonging:

Migrants and Minorities in Contemporary Europe. A. Geddes and A. Favel, eds. Pp. 15-41.

Aldershot: Ashgate.

Csordas, Thomas J.

1994 Embodiment and Experience. Cambridge, UK: Cambridge University Press.

Da Matta, Roberto

1991 Carnivals, Rogues, and Heroes: An Interpretation of the Brazilian Dilemma. Notre Dame:

The University of Notre Dame Press.

Davies, Charlotte A.

2008 [1998] Reflexive Ethnography: A Guide to Researching Selves and Others.

New York/London: Routledge.

Davis, Kathy and Lorraine Nencel

2011 Border Skirmishes and the Question of Belonging: An Authoethnographic Account of Everyday Exclusion in Multicultural Society. Ethnicities 11(4):467-488.

\section{De Gelderlander}

2012 Dialect Sinterklaas bezoekt ouderen in de Zonnekamp. De Gelderlander. November 30, http://www.gelderlander.nl/regio/achterhoek/dialect-sinterklaas-bezoekt-ouderen-in-dezonnekamp-1.3536333, accessed December 14, 2014.

De Jager, Jef

n.d. Rituelen en tradities: Carnaval. http://www.jefdejager.nl/carnaval.php, accessed on August 12, 2015.

De Lima, Philomena

2012 Boundary Crossings: Migration, Belonging/'Un-belonging' in Rural Scotland. In Translocal Ruralism: Mobility and Connectivity in European Rural Spaces. C. Hedberg and R. M. do Carmo, eds. Pp. 203-217. New York: Springer.

Del Percio, Alfonso and Alexandre Duchêne

2012 Commodification of Pride and Resistance to Profit: Language Practices as Terrain of Struggle in a Swiss Football Stadium. In Language in Late Capitalism: Pride and Profit. A. Duchêne and M. Heller, eds. Pp. 43-72. New York/London: Routledge.

\section{Den Besten, Leen}

2014 Carnaval: Een wereld op zijn kop. Old Senders Ni-js. Periodiek van de Cultuurhistorische Vereniging Zevenaar 1:4-10.

Den Exter, Jak

1992 Regionale herkomst van Turken in Nederland. Migrantenstudies 9(3):18-34.

De Swaan, Abram

2001 World of Words. Cambridge: Polity.

De Volkskrant

2012 Boze reacties op nep-Limburgs accent in Sinterklaasjournaal.

De Volkskrant. November 14, http://www.volkskrant.nl/media/boze-reacties-op-nep-limburgs-accentin-sinterklaasjournaal a3347940/\#.UKS7W5I5Szk.facebook, accessed, June 5, 2016. 
DeWalt, Kathleen M. \& Billie R. DeWalt

2002 Participant Observation: A Guide for Fieldworkers. Oxford: Altamira Press.

Dohmen, Joep

$2015 \quad$ Het moest en zou Roermond zijn. NRC Handelsblad, October 20 2015. https://www.nrc.nl/ nieuws/2015/10/20/het-moest-en-zou-roermond-zijn-1548941-a657709, accessed

December 10, 2015.

Dorleijn, Margreet

1991 De Koerden. In Talen in Nederland. J.J. De Ruiter, ed. Pp. 71-89. Groningen: WoltersNoordhoff.

Dorleijn, Margreet and Jacomine Nortier

2005 Turks- en Marokkaans-Nederlands. In Wereldnederlands: Oude en jonge variëteiten van het Nederlands. N. van der Sijs, ed. Pp. 149-183. Den Haag: SDU uitgevers.

\section{Driessen, Geert}

$2009 \quad H o u d o e$ ? Afscheid van streektalen en dialecten? In Dialect, van schoot tot school?

R. Van Hout, V. de Tier and J. Swanenberg, eds. Pp. 69-82. Groesbeek: Stichting Nederlandse dialecten.

Driessen, Gertie

2015 Het is weer rustig in de Donderberg. Dagblad de Limburger/Limburgs Dagblad. April 4, 2015.

Duchêne, Alexandre and Monica Heller

2012 Language in Late Capitalism: Pride and Profit. New York/London: Routledge.

Duranti, Alessandro

1997a Linguistic Anthropology. Cambridge: Cambridge University Press.

1997b Indexical Speech Across Samoan Communities. American Anthropologist 99(2):342-354.

Duyvendak, Jan Willem

2011 The Politics of Home: Belonging and Nostalgia in Western Europe and the United States.

Basingstoke: Palgrave Macmillan.

\section{Eckert, Penelope}

1989 Jocks and Burnouts: Social Categories and Identity in the High School. New York: Teachers College Press.

2000 Language Variation as Social Practice: The Linguistic Construction of Identity in Belten High. Malden, MA \& Oxford, UK: Blackwell.

$2008 \quad$ Variation and the Indexical Field. Journal of Sociolinguistics 12(4):453-476.

2011 Fractals All the Way Down. The Construction of Local Identities through Culture and Language in the Dutch Province of Limburg. Paper at Netherlands Institute for Advanced Study in the Humanities and Social Sciences, Wassenaar (1 December 2011).

El-Aissati, Abderrahman, Louis Boumans, Leonie Cornips, Margreet Dorleijn, and Jacomine Nortier 2005 Turks- en Marokkaans-Nederlands. In Wereldnederlands. Oude en jonge variëteiten van het Nederlands. N. van der Sijs, ed. Pp. 149-183. Den Haag: SDU.

Everts, Jonathan

2010 Consuming and Living the Corner Shop: Belonging, Remembering, Socializing. Social \& Cultural Geography 11(8):847-863.

Fassotte, Nico

2009 Roermond vreest tweede Gouda [Roermond fears second Gouda]. De Telegraaf, October 7. http://www.telegraaf.nl/binnenland/20507298/_Roermond_vreest_tweede_Gouda_.html, accessed December 7, 2015. 
Feld, Steven, and Keith H. Basso, eds.

1996 Senses of Place. School of American Research Advanced Seminar Series.

Santa Fe: School of American Research Press.

Fournillier, Janice B.

2014 Becoming a 'Native Ethnographer': Learning-Teaching Practices in Trinidad and Tobago

Carnival Mas' Camps. Sage Handbook of Case Studies. Thousand Oaks, CA: Sage. http://dx.doi.org/10.4135/978144627305013514679.

Fransen, Theo

n.d. Carnavalkleuren. http://www.fen-nederland.nl/algemeneinformatie/het-verschijnsel-carnaval, accessed October 25, 2016.

\section{Franziskus, Anne and Peter Gilles}

2012 'Et le präis direct etikett?' Non-overlapping Repertoires in Workplace Communication in Luxembourg. Sociolinguistica 26(1):58-71.

Franziskus, Anne, Julia de Bres, and Peter Gilles

2013 'I learnt English - the wrong thing, eh'. Power, Interests and Language Practices Among Cross-border Workers in Luxembourg. In Theorizing Borders through Analyses of Power

Relationships. P. Gilles, H. Koff, C. Maganda, and C. Schulz, eds. Pp. 58-71. Bern: Peter Lang.

Gal, Susan and Judith Irvine

1995 The Boundaries of Languages and Disciplines. How Ideologies Construct Difference. Social Research 62(4):967-1002.

\section{Geertz, Clifford}

1973 The Interpretation of Cultures: Selected Essays by Clifford Geertz. New York: Basic Book, Inc.

1978 The Bazaar Economy: Information and Search in Peasant Marketing. American Economic Review 68(2):28-32.

Geschiere, Peter

2009 The Perils of Belonging: Autochthony, Citizenship and Exclusion in Africa and Europe.

Chicago: Chicago University Press.

Ghorashi, Halleh

2002 Ways to Survive, Battles to Win: Iranian Women Exiles in the Netherlands and the United States. New York: Nova Science Publishers.

Ghorashi, Halleh and Maria Van Tilburg

2006 When Is My Dutch Good Enough? Experiences of Refugee Women with Dutch Labour

Organizations. Journal of International Migration and Integration 7(1): 51-70.

\section{Giampapa, Frances}

2004 The Politics of Identity, Representation, and the Discourses of Self-identification:

Negotiating the Periphery and the Center. In Negotiation of Identities in Multilingual

Contexts. A. Pavlenko and A. Blackledge, eds. Pp. 192-128. Bristol: Multilingual Matters.

\section{Giddens, Anthony}

1984 The Constitution of Society: Outline of the Theory of Structuration. Oakland: University of California Press.

\section{Goffman, Erving}

$1981 \quad$ Forms of Talk. Philadelphia: University of Pennsylvannia Press.

Grondelaers, Stefan, Roeland van Hout, and Mieke Steegs

2010 Evaluating Regional Accent Variation in Standard Dutch. Journal of Language and Social Psychology 29:101-116.

\section{Gumperz, John}

1992 Contextualization and Understanding. In Rethinking Context. Language as an Interactive 
Phenomenon. A. Duranti and C. Goodwin, eds. Pp. 229-253. Cambridge: Cambridge University Press.

1997 Communicative Competence. In Sociolinguistics. A Reader. N. Coupland and A. Jaworksi, eds. Pp. 39-48. New York: St. Martin's Press.

\section{Gupta, Akhil and James Ferguson}

1997 Culture, Power, Place: Explorations in Critical Anthropology. Durham, DC: Duke University Press.

\section{Hagen, Anton and Herman Giesbers}

1988 Dutch Sociolinguistic Dialect Studies. International Journal of the Sociology of Language 73:29-44.

Hall, C. Michael

2015 Elaborating Core-Periphery Relations in Tourism. In Challenges in Tourism Research.

T. Singh, ed. Pp. 162-169. Bristol/Buffalo/Toronto: Channel View Publications.

Hammersley, Martyn and Paul Atkinson

1995 Ethnography: Principles in Practice. New York: Routledge.

Hannerz, Ulf

1989 Culture between Center and Periphery: Toward a Macroanthropology.

Ethnos 54(3-4):200-216.

Harrison, David

2015 Vanishing Peripheries and Shifting Centres: Structural Certainties or Negotiated Ambiguities? In Challenges in Tourism Research. T. Singh, ed. Pp. 170-175. Bristol/Buffalo/Toronto:

Channel View Publications.

Harvey, David

1990 The Condition of Postmodernity. Oxford: Blackwell Publishers.

Have, Paul ten

2007 [1999] Doing Conversation Analysis. London: SAGE Publications.

Helder, Lulu and Scotty Gravenberch

1998 Sinterklaasje, kom maar binnen zonder knecht. Berchem: Drukkerij EPO.

Heller, Monica

2010 The Commodification of Language. Annual Review of Anthropology 39:101-114.

Heller, Monica, Joan Pujolar, and Alexandre Dûchene

2014 Linguistic Commodification in Tourism. Journal of Sociolinguistics 18(4):539-566.

Helsloot, John

1981 De verspreiding van het carnaval in Nederland na 1945. Enkele voorlopige veronderstel-

lingen. In Carnaval: niet van gisteren..! Zes voordrachten. Th. Fransen et al., eds.

Pp. 27-55. 's-Hertogenbosch: Het Noordbrabants Genootschap.

2012 Zwarte Piet and Cultural Aphasia in the Netherlands. Quotidian: Journal for the Study of Everyday Life 3:1-20.

Hermans, Ben

2013 Phonological Features of Limburgian Dialects. In Language and Space: An International Handbook of Linguistic Variation. Volume 3: Dutch. F. Hinskens and J. Taeldeman, eds.

Pp. 336-356. Berlin: Walter de Gruyter.

Henderson, Helene and Sue Ellen Thompson (eds.)

2005 Holidays, Festivals, and Celebrations of the World Dictionary. Detroit: Omnigraphics.

Holly, Werner and Ulrike Hanna Meinhof

2013 'Integration hatten wir letztes Jahr.' Official Discourses of Integration and Their Uptake by Migrants in Germany. In Language, Migration, and Social Inequalities. A. Duchêne, M. Moyer, and C. Roberts, eds. Pp. 171-195. Bristol: Multilingual Matters. 
hooks, bell

1982 Ain't I a Woman? Black Women and Feminism. Boston: South End Press.

House of Representatives of the Netherlands [Tweede Kamer der Staten-Generaal]

2010 Beantwoording 2 sets kamervragen inzake problemen met jongeren in Roermond. https:// www.rijksoverheid.nl/documenten/kamerstukken/2010/01/14/beantwoording-2-sets-

kamervragen-inzake-problemen-met-jongeren-in-roermond-antwoordenroermond, accessed December 3, 2015.

Hymes, Dell

1963 Objectives and Concepts of Linguistic Anthropology. In The Teaching of Linguistics in Anthropology. David G. Mandelbaum, Gabriel W. Lasker, and Ethel M. Albert. Pp. 273-302. Oakland: University of California Press.

1964 Introduction: Toward Ethnographies of Communication. American Anthropologist 66(6):1-34.

2001 [1974] Foundations in Sociolinguistics. London: Routledge.

Inda, Jonathan Xavier, and Renato Rosaldo

2008 [2002] The Anthropology of Globalization: A Reader. Malden/Oxford: Blackwell Publishing. Ingold, Timothy

2008 Anthropology is Not Ethnography. Proceedings of the British Academy 154: 69-92.

Irvine, Judith T. and Susan Gal

2000 Language Ideology and Linguistic Differentiation. In Regimes of Language: Ideologies,

Polities, and Identities. P. Kroskrity, ed. Pp. 35-84. Santa Fe: School of American Research Press.

Jamal, Ahmad

2003 Retailing in a Multicultural World: The Interplay of Retailing, Ethnic Identity and Consumption. Journal of Retailing and Consumer Services 10(1):1-11.

\section{Jaspers, Jürgen}

2004 Marokkaanse jongens en het Antwerps dialect. Taal en Tongval 17: 135-165.

2005 Linguistic Sabotage in a Context of Monolingualism and Standardization.

Language \& Communication 25(3):279-297.

2011 Talking Like a 'Zerolingual': Ambiguous Linguistic Caricatures at an Urban Secondary

School. Journal of pragmatics: an interdisciplinary quarterly of language studies 43(5): 1264-1278.

Jaspers, Jürgen and Lian Malai Madsen

2016 Sociolinguistics in a Languagised World: Introduction. Special issue, "Sociolinguistics in a Languagised World", Applied Linguistics Review 7(3):235-258.

Jaworski, Adam and Crispin Thurlow

2010 Semiotic Landscapes: Language, Image, Space. London: Continuum International Publishing Group.

Johnstone, Barbara

2000 Qualitative Methods in Sociolinguistics. Oxford and New York: Oxford University Press.

2009 Pittsburghese Shirts: Commodification and the Enregisterment of an Urban Dialect.

American Speech 84(2):157-175.

2010 Indexing the Local. In Handbook of Language and Globalization. N. Coupland, ed. Pp. 386406. Hoboken: Wiley-Blackwell.

2013a Speaking Pittsburghese: The Story of a Dialect. Oxford: Oxford University Press.

2013b Ideology and Discourse in the Enregisterment of Regional Variation. In Space in Language and Linguistics. P. Auer, M. Hilpert, A. Stukenbrock, and B. Szmrecsanyi, eds. Pp. 107-127.

Berlin/Boston: Walter de Gruyter. 
2014 Beyond "Enregistered Dialects": Linguistic Form and Social Meaning in Time and Space.

Plenary Address at Sociolinguistics Symposium 20, Jyväskylä, Finland, June 15.

Johnstone, Barbara and Dan Baumgardt

2004 'Pittsburghese' Online: Vernacular Norming in Conversation. American Speech 79

(2):115-145.

Jongenburger, Willy and Jeroen Aarssen

2010 Linguistic and Cultural Exchange and Appropriation: A Survey Study in a Multi-ethnic

Neighbourhood in the Netherlands. Journal of Multilingual and Multicultural Development

22(4):293-308.

Jørgensen, Jens N., Martha S. Karrebæk, Lian M. Madsen, and Janus S. Møller.

2011 Poly-languaging in Superdiversity. Diversities 13(2):23-37.

Karrebaek, Martha S.

2015 The Green Grocer: Everyday Diversity, the Significance of Location and the Five Senses.

Paper presented at conference The Sociolinguistics of Globalization: (de)centring and (de)

standardization, The University of Hongkong, June 5.

Kats, J.C.P.

1985 Remunjs waordebook. [Dictionary of Roermond]. Roermond: Drukkerij en uitgeverij H. van der Marck en Zonen.

\section{Kazemi, Ferdows}

2012 "Vol is vol, wat Wilders zegt', zou mevrouw Jansen nooit te horen krijgen.' NRC Handelsblad, August 17. http://www.volkskrant.nl/opinie/-vol-is-vol-wat-wilders-zegt-zoumevrouw-jansen-nooit-te-horen-krijgen a3302513/, accessed May 23, 2017.

\section{Kearney, Michael}

1995 The Local and the Global: The Anthropology of Globalization and Transnationalism. Annual Review of Anthropology 24:547-65.

Kelly-Holmes, Helen and Sari Pietikäinen

2015 Introduction - Mainstreaming the Periphery in Sociolinguistics. Paper presented at conference Sociolinguistics of Globalization, Hong Kong, June $3-6$.

Knotter, Ad, ed.

2009 Dit is Limburg! Opstellen over de Limburgse identiteit. Zwolle: Waanders Uitgevers.

Knotter, Ad

2011 Regional Character and Regional Stereotypes: Some Thoughts about their Construction in Dutch Limburg. Paper presented at workshop The Construction of Local Identities through Language and Culture, Netherlands Institute for Advanced Study in the Humanities and Social Sciences, Wassenaar, December 1.

Kremer, Joanna

2015 'Where are the Luxembourgers?' Constructions of Place, Belonging and Foreignness. Paper presented at conference Borders and Identities Conference III: Urban Fragmentations, Geisteswissenschaftliche Zentren, Berlin, March 16-19.

\section{Kroon, Sjaak and Jos Swanenberg}

2015 Dialect viert hoogtij tijdens carnaval. Taalunie, volume februari, http://taaluniebericht.org/ artikel/focus/dialect-viert-hoogtij-tijdens-carnaval, accessed September 10, 2016.

\section{Krugman, Paul R.}

1979 Increasing Returns, Monopolistic Competition, and International Trade. Journal of International Economics 9(4):469-79.

Labov, William

1963 The Social Motivation of a Sound Change. Word 19:273-309. 
1966 When Intuitions Fail. Papers from the 32nd Regional Meeting of the Chicago Linguistics Society 32, 76-106.

1991 [1972] Sociolinguistic Patterns. Philadelphia: University of Pennsylvania Press.

Landry, Rodrigue and Richard Y. Bourhis

1997 Linguistic Landscape and Ethnolinguistic Vitality: An Empirical Study. Journal of Language and Social Psychology 16(1):23-49.

Laver, John

$1981 \quad$ Linguistic Routines and Politeness in Greeting and Parting. In Conversational Routine.

Explorations in Standardized Communication Situations and Prepatterned Speech.

F. Coulmas, ed. Pp. 289-304. Rasmus Rask Studies in Pragmatic Linguistics, Volume 2.

New York: Mouton Publishers.

Lefebvre, Henri

1991 The Production of Space. Oxford: Blackwell Publishing.

LePage, Robert B. and Andrée Tabouret-Keller

1985 Acts of Identity: Creole-based Approaches to Language and Ethnicity. Cambridge:

Cambridge University Press.

Low, Setha M.

2003 Embodied Space(s). Anthropological Theories of Body, Space, and Culture. Space \& Culture 6(1):9-18.

Low, Setha M. and Denise Lawrence-Zúñiga, eds.

2003 The Anthropology of Space and Place: Locating Culture. Malden: Blackwell Publishers. Maastricht University

2014 Research Data Management Code of Conduct. Ethical Review Committee Inner City Faculties.

2016 Code of Ethics for Research in the Social and Behavioural Sciences Involving Human Participants, as abided by Maastricht University.

Madsen, Lian M.

2015 Fighters, Girls, and Other Identities: Sociolinguistics in a Martial Arts Club.

Bristol: Multilingual Matters.

Malinowski, Bronislaw

2002 [1929] The Sexual Life of Savages in North-western Melanesia: An

Ethnographic Account of Courtship, Marriage, and Family Life Among the Natives of the Trobriand Islands, British New Guinea. London: Routledge \& Kegan Paul.

\section{Mankekar, Purnima}

2002 'India Shopping': Indian Grocery Stores and Transnational Configurations of Belonging. Ethnos 67(1):75-97.

Massey, Doreen

2005 For Space. London: Sage.

Mathijsen, Marita

2011 De Limburger als de ander. Beek: Drukkerij Econoom.

McCall, Leslie

2005 The Complexity of Intersectionality. Journal of Women in Culture and Society 30 (3):17711800.

Ministry of the Interior and Kingdom Relations [Ministerie van Binnenlandse Zaken en Koninkrijksrelaties] 2011 Wijken in uitvoering. Den Haag: Rijksoverheid Nederland.

Modan, Gabriella G.

2008 Turf Wars: Discourse, Diversity, and the Politics of Place. Hoboken: John Wiley and Sons. 


\section{Moeran, Brian}

2007 From Participant Observation to Observant Participation: Anthropology, Fieldwork and Organizational Ethnography. Creative Encounters Working Papers \#2: 1-25. http://openarchive.cbs.dk/bitstream/handle/10398/7038/wp\%202007-2.pdf? sequence=1, accessed June 19, 2015.

\section{Mommersteeg, Geert and Gerdien Steenbeek}

2008 Inleiding kwalitatief onderzoek. Lecture in course Qualitative Research Methods: Backgrounds and Implementation. Bachelor Cultural Anthropology, Faculty of Social Sciences, University of Utrecht, November 11.

Moors, Thei

1996 Roermondse stadsuitbreidingen sedert 1945. Roermond: Stichting Rura.

Møller, Janus Spindler, and J. Normann Jørgensen

2009 From Language to Languaging: Changing Relations between Humans and Linguistic Features. Acta Linguistica Hafniensia 41(1):143-166.

Municipality of Roermond [Gemeente Roermond]

2016 Bevolkingscijfers per 1 januari 2016. https://www.roermond.nl/organisatie/BS/PuZa/bevolkingscijfers_01012016.pdf, accessed March 14, 2017.

2010 Duurzaam verbinden: aanvraag budget 40+ wijken Donderberg. http://www.roermond.nl/organisatie/KC/docs/donderberg/beleidsdocumenten/Duurzaam_ verbinden_Aanvraag_budget_40_plus_wijken.pdf, accessed April 13, 2015.

n.d. Carnavalsverenigingen. http://lokaaltotaal.nl/roermond/organisaties-enverenigingen/c/carnavalsverenigingen, accessed July 31, 2015.

n.d. Wijken en buurten in Roermond. https://www.roermond.nl/wijkindeling, accessed March 24, 2017.

Neighborhood development plan Donderberg [Wijkontwikkelingsplan Donderberg] 2012 Donderberg, graag! http://www.wijkraaddonderberg.nI/WOP.pdf, accessed April 5, 2015.

Ochs, Elinor

1993 Constructing Social Identity: A Language Socialization Perspective. Research on Language and Social Interaction 26(3):287-306.

Olgun, Ahmet

2013 Allochtoon klinkt als inboorling. NRC Handelsblad, February 21. http://www.nrc.nl/handelsblad/ 2013/02/21/allochtoon-klinkt-als-inboorling-1210977, accessed February 21, 2013.

\section{Olwig, Karen Fog and Kirsten Hastrup}

1997 Siting Culture: The Shifting Anthropological Object. London/New York: Routledge.

\section{Oostendorp, Marc van}

2011 Klanken. In Dialectatlas van het Nederlands. N. Van der Sijs, ed. Pp. 139-193. Amsterdam: Bert Bakker.

Orbons, Piet and Lou Spronck

2009 Limburgers worden Nederlanders. Een moeizaam integratieproces. In Dit is Limburg!

Opstellen over de Limburgse identiteit. A. Knotter, ed. Pp. 33-60. Zwolle: Waanders Uitgevers.

Paasi, Anssi

$2001 \quad$ Europe as a Social Process and Discourse. Considerations of Place, Boundaries and Identity. European Urban and Regional Studies 8(1):7-28.

Pennycook, Alastair and Emi Otsuji

2014a Metrolingual Multitasking and Spatial Repertoires: 'Pizza mo two minutes coming.' Journal of Sociolinguistics 18(2):161-184. 
2014b Market Lingos and Metrolingua Francas. International Multilingual Research Journal 8(4):255-270.

2015 Metrolingualism: Language in the City. New York/London: Routledge

2016 Lingoing, Language Labels and Metrolingual Practices. Applied Linguistics Review

7(3):259-277.

Perry, Jos

2009 't Nachtegaaltje zingt'. Regionalisme in Nederlands-Limburg 1900-1950. In Dit is Limburg!

Opstellen over de Limburgse identiteit. A. Knotter, ed. Pp. 187-227. Zwolle: Waanders Uitgevers.

Pfaff-Czarnecka, Joanna

2011 From "Identity" to "Belonging" in Social Research: Plurality, Social Boundaries, and the Politics of the Self. Working Papers in Development Sociology and Social Anthropology 368:1-18.

Pierce, Joseph, Deborah G. Martin, James T. Murphy

2010 Relational Place-making: The Networked Politics of Place. Transactions of the Institute of British Geographers, 36:54-70.

Pietikäinen, Sari

2015 Multilingual Dynamics in Sámiland: Rhizomatic Discourses on Changing Language. International Journal of Bilingualism 19(2):206-225.

Pietikäinen, Sari and Helen Kelly-Holmes, eds.

2013 Multilingualism and the Periphery. Oxford: University Press.

Pietikäinen, Sari, Helen Kelly-Holmes, Alexandra Jaffe, and Nicholas Coupland

2016 Sociolinguistics from the Periphery. Small Languages in New Circumstances.

Cambridge: Cambridge University Press.

Pink, Sarah

2008 An Urban Tour: The Sensory Sociality of Ethnographic Place-making. Ethnography 8:175-196.

2009 Doing Sensory Ethnography. London: SAGE Publications.

Plattner, Stuart

1985 Markets and Marketing. Lanham, Md.: University Press of America.

Pred, Allan

1985 The Social Becomes the Spatial, the Spatial Becomes the Social: Enclosures, Social Change and the Becoming of Places in Skåne. In Social Relations and Spatial Structures. D. Gregory and J. Urry, eds. Pp. 337-365. New York: Palgrave MacMillan.

Prins, Baukje

2002 The Nerve to Break Taboos: New Realism in the Dutch Discourse on Multiculturalism. JIMIIRIMI 3(3):363-379.

Potter, Rob

2001 Geography and Development: 'Core and Periphery'? Area 33(4):422-427.

Quist, Pia

2010 Untying the Language-Body-Place Connection: A Study on Linguistic Variation and Social Style in a Copenhagen Community of Practice. In Language and Space. An international handbook of linguistic variation. Vol. 1, Theories and methods. P. Auer and J.E. Schmidt, eds. Pp. 632-648. Handbooks of Linguistics and Communication Science, 30(1). Berlin: Mouton de Gruyter.

Raad voor Maatschappelijke Ontwikkeling (RMO)

2012 Tussen afkomst en toekomst. Etnische categorisering door de overheid. Den Haag: Raad voor Maatschappelijke Ontwikkeling. 


\section{Ramachers, Stefanie}

$2014 \quad H o e$ Limburgse kindjes leren 'zingen'. De verwerving van een lexicaal tooncontrast door Limburgse baby's en peuters. In Veldeke Jaarboek 2014. P. Bakkes, H. Sniekers, and T. van de Wijngaard, eds. Pp. 19-32. Vereniging Veldeke Limburg.

Rehbein, Jochen and Jutte Fienemann

2004 Introductions: Being Polite in Multilingual Settings. In Multilingual Communication.

J. House and J. Rehbein, eds. Pp. 223-278. Amsterdam/Philadelphia: John Benjamins.

Ricoeur, Paul

1991 From Text to Action: Essays in Hermeneutics II. Evanston, VA: Northwestern University Press.

Rodenburg, Herman

2015 Het begrip allochtoon door de jaren heen. Republiek Allochtonië. http://www.republiekallochtonie.nl/het-begrip-allochtoon-door-de-jaren-heen, accessed September 7, 2015.

\section{Rosaldo, Renato}

1993 [1989] Culture and Truth: The Remaking of Social Analysis. London: Routledge.

Rowe, Aimee Carrillo 2005 Be Longing: Toward a Feminist Politics of Relation. NWSA Journal 17 (2). 15-37.

Sanabria, Harry

2006 The Anthropology of Latin America and the Caribbean. Boston, New York: Pearson.

Savage, Mike, Gaynor Bagnall, and Brian Longhurst

2005 Globalization and Belonging. London: Sage.

Schmeets, Hans

2014 De religieuze kaart van Nederland, 2010-2013. Den Haag: CBS.

Schreuder, Arjen

2007 In Maastricht praat de Sint Mestreechs. NRC Next, 5 December, http://www.nrc.nl/next/ van/2007/december/05/in-maastricht-praat-de-sint-mestreechs-11446415, July 23, 2014.

Schubert, Torben and Radhamany Sooryamoorthy

2010 Can the Centre-periphery Model Explain Patterns of International Scientific Collaboration Among Threshold and Industrialised Countries? The Case of South Africa and Germany. Scientometrics 83(1):181-203.

Sheriff, Robert E.

1999 The Theft of Carnaval: National Spectacle and Racial Politics in Rio de Janeiro. Cultural Anthropology 14(1):3-28.

Sicakkan, Hakan G. \& Y. Lithman

2005 Theorizing Identity Politics, Belonging Modes and Citizenship. In Changing the Basis of Citizenship in the Modern State. Political Theory and Political Diversity., H. G. Sicakkan and Y. Lithman, eds. Pp. 197-225. New York: Edwin Mellen Press.

Smakman, Dick

2006 Standard Dutch in the Netherlands. A Sociolinguistic and Phonetic Description. Utrecht: LOT 135.

Smaldone, David

2006 The Role of Time in Place Attachment. In Proceedings of the 2006 Northeastern Recreation Research Symposium. R. Burns and K. Robinson, eds. Pp. 47-56. Newtown Square, PA: U.S.

Department of Agriculture, Forest Service, Northern Research Station.

Stienen, Petra

2015 Terug naar de Donderberg: Portret van een wereldwijk. Amsterdam: Nieuw Amsterdam.

Strathern, Marilyn

2004[1991] Partial Connections, Updated Edition. Walnut Creek: Altamira Press. 
Sweetland, Julie

2002 Unexpected but Authentic Use of an Ethnically-marked Dialect. Journal of Sociolinguistics 6(4):514-536.

Thissen, Lotte

2010 Van wie bin jij ' $r$ ien? Een antropologische studie naar essentialistische identiteitsbeelden over Volendam. Unpublished Master's thesis, University of Utrecht.

2013 The Ambiguities of Limburgerness: Language, Place, and Belonging in Limburg, the Netherlands. Etnofoor 25(2):119-143.

2015 'Because here we live in the Netherlands': Languagecultural politics of belonging in a supermarket. Applied Linguistics Review 6(2):195-216.

Thissen, Lotte and Leonie Cornips

2015 Sjtómme Limburger met een zachte G. In Jaarboek van de Vereniging voor Limburgse Dialect- en Naamkunde 17. Pp. 37-41.

Tsing, Anna L.

2005 Friction: An Ethnography of Global Connection. New Jersey: Princeton University Press.

Tuan, Yi-Fu

1991 Language and the Making of Place: A Narrative-Descriptive Approach. Annals of the Association of American Geographers 81(4):648-696.

\section{Van Avermaet, Piet}

2009 'Fortress Europe? Language Policy Regimes for Immigration and Citizenship.' In G. Hogan-Brun, C. Mar-Molinero, P. Stevenson, eds. Pp. 15-43. Language, Ideologies, Policies and Practices. Language and the Future of Europe. Basingstoke: Palgrave Macmillan.

\section{Van Beek, Sjors}

2010 Donkere jongens met capuchons.

http://www.binnenlandsbestuur.nl/sociaal/achtergrond/achtergrond/donkere-jongens-metcapuchons.154850.lynkx, accessed, April 5, 2015.

\section{Van Bezooijen, Renée}

1997 Normen met betrekking tot het Standaard Nederlands. Taal en Tongval 10: 30-48.

2002 Aesthetic Evaluation of Dutch. Comparisons Across Dialects, Accents and Languages. In Handbook of perceptual dialectology, Vol 2. D. Long, and D. Preston, eds. Pp. 13-31.

Amsterdam: John Benjamins.

Van de Mortel, Hans

2012 Historische introductie Roermond. In Roermond. Beeld van een stad. L. Wolters, ed. Pp. 2449. Roermond: X-Cago/Koos Hussem.

Van de Poll, Wilfred

2015 'Allochtoon' is vernederend. Trouw, July 14, 2015. http://www.trouw.nl/tr/nl/5133/

Media-technologie/article/detail/4100606/2015/07/14/Allochtoon-is-vernederend.dhtml, accessed September 7, 2015.

Van der Heijden, Hanneke

1991 De Turken. In Talen in Nederland. J.J. De Ruiter, ed. Pp. 230-257. Groningen: WoltersNoordhoff.

Van der Schans, Jan Willem, Leo Dvortsin, Isabelle van den Berg, Dorit Haubenhofer, Jan Hassink, Marcel Vijn, and Abco de Buck

2009 Marktkansen voor etnisch voedsel en etnische diensten. Den Haag: LEI Wageningen UR. Van der Schee, Ron

2013 Carnaval verboden? Historiek, February 5, 2013. http://historiek.net/carnaval verboden/ 20702/, accessed on March 30, 2014. 
Van der Torre, Edward, Afke Besselink, Vincent Dijk, Nick Koeman, and Laurens van der Varst

2007 Veel voorkomende criminaliteit in Roermond: Van twistpunt naar speerpunt?! Den Haag:

COT Instituut voor Veiligheids- en Crisismanagement.

Valentine, Gill, Deborah Sporton, and Katrine Bang Nielsen

2008 Language Use on the Move: Sites of Encounter, Identities and Belonging. Transactions of the Institute of British Geographers, New Series 33(3):376-387.

Vlakveld, S.

2005 Turkse handel van groente en fruit in Duitsland: een kwalitatief onderzoek naar de Turkse groothandel, groenteman en consument in Duitsland. Productschap Tuinbouw 7.

Urlings, Guus

2015a Het vuur van de vastelaovend dooft met de jaren. Dagblad de Limburger/Limburgs Dagblad. January 24, 2015.

2015b Half Limburg viert wel carnaval. De Limburger. January 20, 2015: https://www.vastelaovendinlimburg.n//2015/01/20/half-limburg-viert-wel-carnaval/, accessed October 25, 2016.

Wacquant, Loïc

2008 Urban Outcasts: A Comparative Sociology of Advanced Marginality. Cambridge: Polity.

Wall, Geoffrey

2015 Tourism in Peripheries. In Challenges in Tourism Research. T. Singh, ed. Pp. 180-184. Bristol/ Buffalo/Toronto: Channel View Publications.

Wallerstein, Immanuel

1974 The Modern World-System. New York: The Academic Press.

Wang, Xuan, Max Spotti, Kasper Juffermans, Leonie Cornips, Sjaak Kroon, and Jan Blommaert 2013 Globalization in the Margins. Tilburg Papers in Culture Studies 73.

Welle, Christian, Julia de Bres, and Anne Franziskus

2015 Intercultural Work Environments in Luxembourg: Multilingualism and Cultural Diversity Among Cross-border Workers at the Workplace. Multilingualism and Intercultural Studies, Working Paper 1:3-22.

Wiese, Heike

2012 Kiezdeutsch: Ein neuer Dialekt entsteht. München: C.H. Beck.

2013 From Feature Pool to Pond: The Ecology of New Urban Vernaculars. Working papers in Urban Language \& Literacies 104.

Wijers, Carla

1995 Prinsen \& Clowns in het Limburgse Narrenrijk. Amsterdam: P.J. Meertens Instituut.

Wolcott, Harry F.

$1999 \quad$ Ethnography. A Way of Seeing. Oxford: Altamira Press.

Woolard, Kathryn A.

2008 Why Dat Now?: Linguistic-anthropological Contributions to the Explanation of Sociolinguistic Icons and Change. Journal of Sociolinguistics 12(4):432-452.

Wright, Wynne and Alexis Annes

2013 Halal on the Menu?: Contested Food Politics and French Identity in Fast-food. Journal of Rural Studies 32:388-399.

Yanow, Dvora and Marleen van der Haar

2013 People Out of Place: Allochthony and Autochthony in the Netherlands' Identity discourse - Metaphors and Categories in Action. Journal of International Relations and Development 16:227-261.

Youkhana, Eva

2015 A Conceptual Shift in Studies of Belonging and the Politics of Belonging. Social Inclusion 3(4): 10-24. 


\section{Yuval-Davis, Nira}

2006 Belonging and The Politics of Belonging. Patterns of Prejudice 40(3):197-214.

2007 Intersectionality, Citizenship and Contemporary Politics of Belonging. Special Issue,

"Contesting Citizenship: Comparative Analyses", Critical Review of International Social and

Political Philosophy 10(4): 561-574.

Yuval-Davis, Nira, Kalpana Kannabiran, and Ulrike M. Vieten, eds.

2006 The Situated Politics of Belonging. London/Thousand Oaks, CA/New Dehli: Sage Publications.

\section{Illustrations, media, and websites}

\section{De Katers}

1990 Vastelaovesvereniging 'De Katers'. 4 × 11 Jubileumboek. Roermond: Drukkerij van der Marck bv. Under the supervision and coordination of Leon Hamans and Jean Egtberts.

2012 Veer gaon allemaol antropologie sjtudere!! [We are all going to study anthropology!!] In KlassjeNeel Vastelaovesgezet V De Katers 2013.

n.d. Historie. http://dekaters.nl/historie/historie/, accessed on November 11, 2014.

\section{Facebook page L1}

2012 Ophef over het sinterklaasjournaal. November 14 2012. https://www.facebook.com/L1 mburg, accessed June 10, 2016.

Flycatcher

$2015 \quad$ Helft Limburgers mijdt carnaval.

https://www.flycatcherpanel.nl/nld/nieuws/?newsid=1186\&cat2=, accessed October 25, 2016.

\section{Kadaster}

1895 Map of Maasniel in 1842/1843, published by land register office Kadaster, Emmen. http://www.maasniel.nl, accessed and obtained permission to use from Dominique Clerkx on November 27, 2014.

\section{Rabobank}

2012 Starter in Beeld: Dost Market in Roermond, droom wordt werkelijkheid [Starter on display: Dost Market in Roermond, a dream come true]. https://www.rabobank.nl/ images/1441_dost_market_29488288.pdf, accessed April 14, 2015.

\section{Roermond Nieuws.nl}

2015 Koninklijke onderscheiding voor Leon Hamans (66) uit Maasniel. http://roermond.nieuws.n//nieuws/ 10314/koninklijke-onderscheiding-voor-leon-hamans-66-uit-maasniel/, accessed July 31, 2015.

Sinterklaasjournaal, Het

2012 Neppe Roermondenaren bij Het Sinterklaasjournaal. YouTube, 13 November 2012. https:// www.youtube.com/watch?v=sMy_F_GGYL8, accessed October 25, 2014.

Sjommelmert

n.d. Informatie. http://www.sjommelmert.nl, accessed September 16, 2015.

\section{Stichting MailDB}

n.d. NO-NO and NO-YES mailbox stickers (Figure 4.16). https://www.milieucentraal.nl/minderafval/afval-scheiden-en-recyclen/afval-verminderen/reclamedrukwerk/, accessed April 12, 2017 and obtained permission to use on July 11, 2017.

\section{Traanberg Partners, Architectuur and Bouwmanagement.}

n.d. Floor plan of De Donderberg neighborhood shopping mall before the renovation (Figure 7.4). http://www.traanbergpartners.nl/winkelcentrum-donderberg-roermond, accessed and obtained permission to use on April 14, 2015. 
Vereniging voor Vreemdelingenverkeer Limburg

2008 Liefde voor het leven. http://media.liefdevoorhetleven.nl/mediagallery/Gallery, accessed in August 2012.

Wassen, Arnold

n.d. Leefde veur de sjtad [Love for the city]. Performed by Lei Driessen.

\section{Personal communications}

\section{Koerts, Jan}

2015 Personal communication via e-mail about figures of Donderberg. April 17, 2015 and April 24, 2017.

Maurice, De Katers' secretary

2015 Personal communication via e-mail about member figures De Katers, December 11. 


\section{Nederlandse samenvatting}

Talking In and Out of Place onderzoekt de manieren waarop mensen taal gebruiken om, in interactie met anderen, betekenis te geven aan de wereld om hen heen. Dergelijke kwesties lijken steeds belangrijker te worden in een wereld die constant in beweging is en waar mensen zich dagelijks dienen te verhouden tot en worden geconfronteerd met meertaligheid, culturele diversiteit en gevoelens van in- en uitsluiting.

Om deze kwesties te onderzoeken heb ik etnografisch veldwerk verricht in de stad Roermond in Limburg. Deze Nederlandse provincie in het zuidoosten van het land wordt vaak gezien en verbeeld, zowel door inwoners van Limburg als door mensen daarbuiten, als een provincie met een sterke regionale identiteit gebaseerd op tradities en dialecten die als lokaal en regionaal worden ervaren. Hierdoor en door de relatief recente aansluiting van Limburg tot de Nederlandse natiestaat in 1867 kent deze provincie verschillende machtsdynamieken tussen centrum en periferie. Deze machtsdynamieken zijn interessant voor dit onderzoek dat de rol van taalpraktijken in betekenisgeving aan plekken en sociale relaties onder de loep neemt.

Roermond is een stad gelegen in Midden-Limburg met de meeste culturele en talige diversiteit vóór steden als Maastricht (de hoofdstad gelegen in het zuiden van Limburg) en Venlo (gelegen in Noord-Limburg). Binnen Roermond heb ik onderzoek gedaan op drie plekken: bij carnavalsvereniging De Katers uit de voormalige gemeente Maasniel, op het Munsterplein in de Roermondse binnenstad en in de kleinschalige supermarkt Dost Market in de wijk De Donderberg. Deze drie locaties zijn bewust gekozen om de centrale onderzoeksvraag - hoe mensen taal gebruiken om betekenis te geven aan de wereld om hen heen - vanuit verschillende perspectieven te benaderen.

Door participerende observatie en etnografische zelfreflectie, beschreven in Hoofdstuk 2, heb ik in deze drie locaties gekeken hoe mensen zich plekken toe-eigenen door bepaalde talige en culturele praktijken te verbinden aan deze plekken en de interacties aldaar. De veldwerkervaringen en -inzichten ter plaatse hebben mij in de richting van vier 'attenderende begrippen' (sensitizing concepts) geduwd: dynamieken van centrum-periferie, processen van plektoe-eigening (place-making processes), de politiek van er wel of niet bijhoren (politics of (un)belonging) en 'buitenlandsheid' (foreignness). Deze concepten zijn empirisch geïnformeerd, leidend in het beschrijven, duiden en analyseren van de bestudeerde sociale realiteiten en ondersteunend in het beantwoorden van de centrale onderzoeksvraag. De drie delen van dit proefschrift geven een gedetailleerde beschrijving van deze plekken en analyseren interacties tussen en met verschillende personen die hebben plaatsgevonden tijdens het veldwerk.

Deel I sleurt de lezer mee in een polonaise bij carnavalsvereniging De Katers uit Maasniel. Tijdens carnaval wordt de sterk beleefde regionale identiteit van Limburg gevierd en worden dialecten veelvuldig gebruikt. Bovendien is het de periode waarin carnavalsverenigingen verwikkeld raken in een carnavaleske en speelse rivaliteit in toespraken en activiteiten tijdens carnavalsrecepties. Hoofdstuk 3 beargumenteert waarom de viering van carnaval binnen carnavalsverenigingen in Limburg een interessante context voor onderzoek biedt. De specifieke keuze voor carnavalsvereniging De Katers voor het veldwerk wordt toegelicht in Hoofdstuk 4. Maasniel kent een tumultueuze geschiedenis: deze voormalig onafhankelijke gemeente, waaraan De Katers verbonden zijn, werd geannexeerd - zoals leden van De Katers het noemen - in 1959 door de stad Roermond. Die 
historische gebeurtenis ligt tot op de dag van vandaag aan de basis van het motto van De Katers: Neel blief Neel (Maasniel blijft Maasniel). De veldwerkervaringen, participerende observaties en gesprekken met leden van De Katers schetsen in Deel I hoe leden van de vereniging zich Maasniel als plek toe-eigenen door haar identiteit als voormalige gemeente voortdurend te benadrukken en te herhalen. Zij bewerkstelligen dit voornamelijk door processen van place-making waarin het gebruik van symbolen, zoals kleding en standbeelden, en dialect centraal staan (Hoofdstuk 4). Bovendien reproduceren de carnavalspraktijken bij De Katers niet enkel het stereotype beeld waarin de provincie Limburg onlosmakelijk verbonden wordt met carnaval, dialectgebruik en vaststaande ideeën over wat Limburgsheid inhoudt. Het bestudeerde prinsuitroepen evenement in Hoofdstuk 5, waarin de vieringen van Sinterklaas en carnaval tegelijkertijd plaatsvinden, bewijst dat dialect niet de enige belangrijke gesproken variant is binnen carnavalspraktijken en dat carnavalsvieringen zeer gelaagd kunnen zijn. Zo worden er tijdens het evenement ook lokale en kleinschaliger centrum-periferie dynamieken naar voren gebracht die complexer zijn dan de alomtegenwoordige Limburg versus 'Holland' dynamiek. De hoofdstukken over De Katers tonen aan dat carnavalspraktijken kunnen refereren aan verschillende centrum-periferie dynamieken tussen Limburg en 'Holland', tussen Maasniel en Roermond, tussen het centrum van Maasniel en andere gebieden in Maasniel en tussen De Katers en andere carnavalsverenigingen. De discussie tussen de carnavalsvorst en de nationale figuur Sinterklaas demonstreert daarnaast hoe taalpraktijken deze dominante machtsverhoudingen kunnen uitdagen, omverwerpen en kantelen. Ik betoog dat deze complexe centrumperiferie dynamieken van betekenis zijn voor place-making praktijken bij De Katers die blootleggen wie er gezien wordt als 'één van ons' (in place) of als buitenstaander (out of place).

Deel II laat de lezer plaatsnemen naast twee mannen op een zonnige zomerdag op een bankje op het Munsterplein in de binnenstad van Roermond. Hoofdstuk 6 bestudeert hoe deze mannen, in interactie met elkaar en met mij, zich Limburg en Roermond toeeigenen als plekken waarin zij buitenstaanders zijn (out of place). De analyses van hun taal- en cultuurpraktijken onthullen echter meer ambivalente gevoelens van er wel en niet bijhoren (belonging en unbelonging). Deze gevoelens, die sterk afhankelijk zijn van de context, suggereren dat beide mannen onderlinge verbondenheid voelen op basis van hun gedeelde gevoel er niet bij te horen in Limburg en Roermond. Dit fenomeen noem ik belonging through unbelonging. De interactie en analyse benadrukken duidelijk de waarde van etnografisch onderzoek en zelfreflectie, omdat mijn eigen aanwezigheid tijdens de interactie mij in staat stelt te onderzoeken hoe de mannen mijn uiterlijk interpreteren en welk effect dit heeft op onze discussie over wie er wel of niet bij hoort in Limburg en Roermond (politics of (un)belonging).

In Deel III lokt de geur van versgebakken Turks brood de lezer naar binnen bij Dost Market, een kleine supermarkt in de wijk De Donderberg in het oosten van Roermond. De Donderberg, beschreven in Hoofdstuk 7, wordt doorgaans gezien als een diverse wijk waar mensen met verschillende culturele en talige achtergronden wonen, werken en leven.

Deze mensen komen elkaar tegen bij Dost Market wanneer zij hun dagelijkse boodschappen doen. Daarbij gebruiken ze talige vormen die geassocieerd kunnen worden met verschillende talen. Observaties, veldwerkervaringen en zelfreflectie binnen Dost Market hebben mij in Hoofdstuk 8 geïnspireerd tot het ontwikkelen van het analytische concept 'buitenlandsheid' (foreignness) om grip te krijgen op de paradoxale vormen van erbij horen door er niet bij te horen (belonging through unbelonging). Foreignness helpt, met andere 
woorden, duiding te geven aan de inspanningen die mensen doen om een gedeeld gevoel van 'anders-zijn' binnen een bepaalde plek vast te stellen en op basis daarvan een relatie met elkaar te bouwen. Daarnaast maakt de analyse van het talige landschap (linguistic landscape) in Hoofdstuk 8 duidelijk hoe werknemers en klanten van Dost Market verschillende talige vormen gebruiken in schrift en interacties waarmee er betekenis wordt gegeven aan deze plek als geheel. Deze taalpraktijken onthullen hoe werknemers en klanten in Dost Market zich identificeren en hoe zij uiting geven aan verschillende gevoelens van er wel of niet bij horen, gevoelens die sterk afhankelijk zijn van de context en situatie van de interacties. De analyse van de interactie tussen de eigenaar en zijn klanten in Hoofdstuk 9 markeert, tot slot, hoe mensen gebruiken maken van talige vormen om gevoelens van er wel of niet bijhoren te claimen, legitimeren en uit te dagen. Gevoelens die dynamisch en zelfs tegenstrijdig blijken te zijn.

De drie onderzoekscasussen delen een aantal overeenkomsten, ondanks dat ze alle drie hun specifieke inzichten geven en ze alle drie verschillende kwesties en problematieken aan het daglicht brengen. Geconcludeerd kan worden dat de drie casussen bijdragen aan een beter begrip van taalpraktijken, betekenisgeving aan plekken, gevoelens van er wel of niet bij horen, sociale en centrum-periferie relaties. Dit zijn concepten die centraal bleken in alle hoofdstukken. In dit proefschrift heb ik, op basis van mijn empirisch materiaal, vier conclusies aangedragen die verklaren hoe mensen betekenis geven aan de plekken om hen heen en de mensen waarmee zij contact hebben.

De eerste conclusie stelt dat, in tegenstelling tot hardnekkige taalideologieën, taalpraktijken niet voorspeld kunnen worden op basis van de achtergronden van sprekers. Zo hoeft, bijvoorbeeld, het feit dat een persoon (of zijn/haar ouders) niet in Limburg is geboren en getogen of een uiterlijk heeft dat doorgaans niet herkend wordt als Nederlands of Limburgs niet automatisch te betekenen dat deze persoon geen dialect spreekt en/of verstaat. Mensen spreken nooit een 'hele' taal, maar gebruiken taal als bron om talige elementen uit te selecteren afhankelijk van de plek waarin zij zich bevinden. Zij creëren op deze wijze een voortdurend veranderend talig repertoire. Bovendien laten de onderzoekscasussen zien dat er een groot verschil kan bestaan tussen wat mensen geloven en zeggen dat ze doen (taalideologie) en wat ze in werkelijkheid doen (taalpraktijk). Zo begroet de mede-eigenaar van de supermarkt veel klanten dagelijks in het dialect, terwijl diezelfde mede-eigenaar beweert dat het voor hem "als Turk" raar is om dialect te spreken.

De tweede conclusie van dit proefschrift betoogt dat processen van plektoe-eigening (place-making processes) uiting geven aan ideeën over wie en welk gedrag er wel of niet bij mag horen in een bepaalde plek. Taalpraktijken geven, naast rituelen en symbolen, deze processen mede vorm, waarin mensen zich talig verbinden met of distantiëren van anderen. Door het gebruik van talige en culturele middelen zijn mensen in staat om fysieke ruimtes te transformeren naar sociale plekken. Zo bestond binnen carnavalsvereniging De Katers de ongeschreven norm dat er tijdens activiteiten alleen dialect gebruikt wordt en dat het gebruik van Nederlands als out of place wordt beschouwd, terwijl het gebruik van meertalige repertoires als normaal wordt beschouwd binnen Dost Market.

De derde conclusie geeft inzicht in de manier waarop machtsdynamieken van centrum en periferie zich manifesteren in het dagelijks leven. Centrum-periferie dynamieken worden op verschillende niveaus gereproduceerd in steeds kleiner wordende dynamieken; de tegenstelling Limburg versus 'Holland' wordt op regionaal niveau bijvoorbeeld Roermond versus Maastricht en op lokaal niveau Roermond versus Maasniel. In dit 
proefschrift toon ik aan dat zogenaamde perifere gebieden, zoals Limburg, geen talig en cultureel homogeen geheel zijn waar mensen in harmonie met elkaar samenleven en waar geen meertaligheid en culturele diversiteit bestaat. Elke onderzoekscasus demonstreert de complexiteit van dagelijkse situaties in een vermeend perifeer gebied als Limburg.

Tot slot stelt de vierde conclusie dat erbij horen door er niet bij te horen (belonging through unbelonging) door iedereen ervaren kan worden. Erbij horen (belonging) gaat altijd gepaard met er niet bijhoren (unbelonging), simpelweg om het feit dat wanneer een groep stelt bij elkaar te horen, ze daarbij inherent anderen uitsluit. De mensen die worden uitgesloten kunnen op hun beurt weer een onderling gevoel van erbij horen door er niet bij te horen ontwikkelen op basis van hun gedeelde 'andersheid'. In dit proefschrift heb ik het concept 'buitenlandsheid' (foreignness) aangedragen om de behoefte te begrijpen die mensen hebben om hun gedeelde 'andersheid' vast te stellen en op basis daarvan verbondenheid te ontwikkelen. Ondanks dat het concept in eerste instantie is gebaseerd op ervaringen en observaties in de supermarkt waar werknemers en klanten voortdurend op zoek zijn naar hun gedeelde 'andersheid' op basis van taal, herkomst en religie, blijkt 'buitenlandsheid' naadloos toegepast te kunnen worden op de andere onderzoekscasussen. Zo kon Limburg enkel en alleen haar regionale identiteit ontwikkelen op basis van haar gedeelde 'buitenlandsheid' binnen 'Holland'; carnavalsvereniging De Katers vindt haar bestaansrecht voornamelijk in de 'buitenlandsheid' van Maasniel binnen Roermond; en de twee mannen op het bankje lijken bij elkaar te horen door hun gedeelde 'buitenlandsheid' binnen Limburg. Zo concludeer ik dat 'buitenlandsheid' een gevoel is dat ervaren kan worden op elk tijdstip, in elke plek en, belangrijker nog, door iedereen, ongeacht iemands (zelf-)toegeschreven achtergrond. Dit betekent dat ook zij die als 'autochtonen' worden bestempeld in het publieke discours zich 'anders' of 'buitenlands' (foreign) kunnen voelen afhankelijk van de context en de talige en culturele praktijken die verbonden worden aan een bepaalde plek. De onderzoekscasussen demonstreren dat gevoelens van 'buitenlandsheid' dynamisch en meervoudig zijn: een individu kan zich op een bepaald moment met een plek identificeren terwijl datzelfde individu zich er niet bij hoort voelen op een ander moment.

Talking In and Out of Place tracht bij te dragen aan het begrip over hoe we met elkaar omgaan in hedendaagse samenlevingen die sterk worden beïnvloed door mondialiseringsprocessen. Zoals ik verder zal uitdiepen in het valorisatie addendum, ben ik van mening dat de studie van taalpraktijken onmisbaar is om inzicht te krijgen in de manieren waarop mensen zich plekken toe-eigenen en gevoelens van er wel en niet bij horen vormen in dagelijkse interacties. Deze inzichten informeren ons over sociale relaties en de ideeën en percepties die mensen hebben in huidige samenlevingen. Dit zijn inzichten die, in mijn ogen, als thermometer voor sociale cohesie en maatschappelijk welzijn kunnen dienen. Hoewel nationale en regionale instituties, zoals het Centraal Bureau voor de Statistiek en nationaal, provinciaal en lokaal bestuur, veelal vertrouwen op inzichten op basis van enquêtes die mensen, hun (taal)praktijken en gevoelens van in- en uitsluiting in hokjes plaatsen, stelt dit proefschrift dat er meer oog zou moeten zijn voor de talige en culturele praktijken van mensen binnen de alledaagse plekken waarin zij zich begeven. Alleen door middel van een dergelijke etnografische methode is het mogelijk inzicht te vergaren in de manieren waarop huidige samenlevingen zich continue hervormen waarbij taal de sleutelrol speelt in de beleefde gevoelens van in- en uitsluiting binnen verschillende plekken. Oftewel, de manieren waarop mensen anderen en zichzelf zeggen er wel of niet bij te horen: Talking In and Out of Place. 


\section{Valorization Addendum: Kansen voor kennisvalorisatie}

Considering the relevance of my research for the Netherlands as a whole, I have decided to write this Valorization Addendum in Dutch. This text box covers the main points raised in this addendum.

During the research project, the following valorization activities were carried out:

- Popular publications in local magazines and edited volumes;

- Popular online blog for inhabitants of Roermond about research observations;

- Popular talks on several occasions throughout Limburg;

- Media appearances on local television and radio in Limburg.

The following valorization opportunities are proposed:

- Campaign 'Inclusive language': This dissertation's ethnographic insights may foster awareness within the Netherlands and elsewhere that ideological associations between particular speakers and language resources are not in line with daily realities. A campaign should plea for those speakers who are able to use and understand, and learning, dialect, but who are not recognized as such for different reasons. Spokespersons and role models of this campaign should defy existing stereotypes.

- Training: The results of this research could be used to develop training opportunities that teach participants to become aware of their beliefs regarding language use and the inclusionary and exclusionary effects that language practices may have for their interlocutors. Such training would be especially useful for social workers, civil servants, and teachers but could also help to promote self-awareness and open-minded attitudes among primary school pupils.

- Critical evaluation of policies: This research encourages policy makers to assess assumptions based on surveys and instead to consider in-depth ethnographic insights into the ways that people shape place attachments and social relations through language practices. These ethnographic insights should be regarded as a thermometer for social cohesion and societal health, which is especially relevant for policy makers dealing with different groups within the Netherlands, language and integration tests, and Dutch youngsters that do not primarily identify with the Netherlands. Moreover, this dissertation strongly recommends avoiding the use of terms such as autochtoon and allochtoon, since these terms do not cover daily linguistic and cultural realities at all.

- Linguistic Landscape as a tool: The expanded 'linguistic landscape' paradigm put forward in this dissertation could be used as a tool for entrepreneurs and shopkeepers who want to optimize their marketing and branding strategies by using different linguistic resources on display and in interaction in their stores.

If you have any questions or you would like to further discuss the valorization opportunities of this research, please contact me via e-mail: lottethissen@hotmail.com.

In dit addendum zet ik uiteen hoe de kennis van mijn proefschrift Talking In and Out of Place benut kan worden voor de maatschappij als geheel door een vertaling te maken naar diensten en services. 


\section{Kennisvalorisatie tijdens het onderzoek}

Vanuit de overtuiging dat etnografisch onderzoek geworteld dient te zijn in de samenleving, heb ik gedurende dit promotieonderzoek verschillende valorisatieactiviteiten ondernomen waarbij ik opgedane kennis heb gedeeld met 'het veld', voornamelijk inwoners van Roermond maar ook van daarbuiten.

Publieke publicaties: Toen duidelijk werd dat ik veldwerk zou gaan doen bij carnavalsvereniging De Katers uit Maasniel, heb ik mezelf en het onderzoek geïntroduceerd door middel van een in dialect geschreven artikel in het gedrukte magazine KlassjeNeel. Niet alleen was dit een handige manier om de leden van De Katers op de hoogte te brengen van mijn komst, ik vond het ook belangrijk dat de vereniging wist wat de insteek van mijn onderzoek was en dat ik ten alle tijden mijn recorder desgewenst uit zou zetten. Om de vereniging op de hoogte te houden, heb ik in het magazine van seizoen 2013/2014 eveneens een in dialect geschreven artikel gepubliceerd over de (voorlopige) onderzoeksresultaten. Voor het seizoen 2017/2018 staat wederom een artikel gepland om de vereniging op de hoogte te brengen van de promotie op 11 januari 2018. Daarnaast heb ik samen met mijn promotor Leonie Cornips gepubliceerd in het Jaarboek van de Vereniging voor Limburgse Dialect- en Naamkunde.

Publieke online blog: Vanaf 2012 ben ik een samenwerking aangegaan met website Roermondenaar.nl. Gedurende een jaar zijn daar zeven blogs van mij gepubliceerd over mijn veldwerkervaringen in Roermond. De website diende als een uitstekend platform om iets terug te geven aan de inwoners van Roermond en hen te informeren over mijn onderzoeksactiviteiten en -bevindingen.

Publieke lezingen: Naast deze verschillende publicaties heb ik eveneens publieke lezingen gegeven. Twee lezingen hebben plaatsgevonden in Roermond. De eerste lezing was tijdens Salon Remunj in februari 2012 waar ik geïnteresseerde inwoners van Roermond heb geïnformeerd over de start van mijn veldwerk in de stad. De lezing kan, achteraf gezien, bestempeld worden als kennisvalorisatie alsook voorbereiding op mijn veldwerk omdat ik er belangrijke contacten heb opgedaan voor mijn veldwerk. De tweede lezing in Roermond was tijdens de lenteborrel in 't Paradies, een senioren ontmoetingscentrum in het centrum van de stad. Hier heb ik samen met Leonie Cornips een lezing verzorgd over ons onderzoek. Daarnaast hebben we de, om en nabij, honderd aanwezigen laten meedoen aan een mental map workshop waarin de deelnemers konden aangeven waar in Limburg het mooiste en lelijkste dialect gesproken wordt. ${ }^{87}$ De andere twee publieke lezingen hebben plaatsgevonden in Laren en Maastricht. In Laren hebben Leonie Cornips en ik een lezing verzorgd bij 't Limburgs Stamboek van 't Gooi, bijeenkomsten die voor en door Limburgers worden georganiseerd die buiten Limburg zijn gaan wonen maar die eens per maand samenkomen om dialect te spreken en zich te laten informeren over actuele Limburgse zaken. Onze lezing heeft hen op de hoogte gebracht van ons onderzoek en handvatten meegegeven om duiding te geven aan hun eigen gevoelens van erbij horen (belonging) en er niet bijhoren (unbelonging) als Limburger buiten Limburg. Tot slot hebben Leonie Cornips en ik een lezing over ons onderzoek verzorgd tijdens de opening van het culturele seizoen, genaamd Parcours of Arts and Sciences, in Maastricht. De doelgroep bestond uit geïnteresseerden uit Maastricht en daarbuiten. In deze lezing

\footnotetext{
${ }^{87}$ Zie voor uitkomsten van dit mental map onderzoek Cornips (in press).
} 
hebben wij verschillende culturele vormen (Facebook pagina's, liedjes over Limburgse identiteit en dialectvertalingen van Harry Potter boeken) de revue laten passeren en duiding gegeven aan de manier waarop taal ingezet wordt als belangrijk instrument in de constructie en beleving van gevoelens van Limburgsheid.

Mediaoptredens: Tijdens het promotietraject heb ik verschillende mediaoptredens gedaan om te praten over mijn onderzoek. In november 2012 is er een uitgebreide reportage gemaakt door omroep L1 waarin ik uitleg en laat zien hoe etnografische methoden werken en wat de waarde daarvan is voor mijn onderzoek naar taalgebruik, plek en belonging. Daarnaast ben ik in 2014 geïnterviewd voor het wijkblad van De Donderberg, de wijk waarin ik ben opgegroeid en waar ook Dost Market gelegen is. Dit interview ging zowel over mijn eigen ontwikkeling als over mijn promotieonderzoek in Roermond. In dezelfde periode ben ik geïnterviewd door publiciste Petra Stienen voor haar boek Terug naar de Donderberg: Portret van een wereldwijk. In dit boek vraagt zij zich af wat is er geworden van de Donderberg, waar inmiddels mensen vanuit de hele wereld hun thuis hebben gevonden en hoe bewoners, politici en media met vragen over identiteit, migratie en participatie omgaan. Naar aanleiding van ons gesprek heeft zij een passage geschreven over de wisselwerking tussen taal en identiteit met voorbeelden uit mijn onderzoek. In mei 2015 ben ik geïnterviewd door L1 Radio over mijn bijdrage in de bundel Het dorp en de wereld. Over dertig jaar Rowwen Hèze (onder redactie van Leonie Cornips en Barbara Beckers) waarin ik ben ingegaan op de manier waarop de band Rowwen Hèze appelleert aan een gevoel van Limburgsheid en verbondenheid door hun dialectmuziek. Tot slot ben ik in juni 2017 geïnterviewd door de regionale omroep van Maastricht voor het programma Boer Zeuk Sjeng. In deze reportage heb ik het vermeend chauvinisme van Maastrichtenaren geduid binnen het kader van mijn eigen onderzoek.

\section{Kansen voor kennisvalorisatie}

In deze paragraaf zal ik uiteenzetten waar ik kansen voor kennisvalorisatie zie en welke mogelijkheden ik zie om de onderzoeksresultaten en -inzichten van dit proefschrift in te zetten voor de maatschappij als geheel.

\section{Bewustzijnscampagne Insluitende taal}

Eén van de belangrijkste conclusies van dit proefschrift is dat taalgebruik niet of nauwelijks voorspeld kan worden op basis van de plek waar we ons bevinden, geboren en getogen zijn of de achtergrond en uiterlijke kenmerken van personen. Gedurende ons leven komen we in contact met veel verschillende gesprekspartners en de talige middelen die deze gesprekspartners gebruiken die wij op onze beurt toevoegen aan ons repertoire en al naar gelang kunnen inzetten in bepaalde situaties. Toch heeft dit proefschrift laten zien hoe talige middelen worden geassocieerd met bepaalde gebruikscontexten en sprekers: dialect wordt verwacht bij de carnavalsvereniging, maar niet in de 'Turkse' supermarkt. Het proefschrift heeft laten zien hoe dergelijke associaties kunnen resulteren in het in- en uitsluiten van personen door taalgebruik.

Tijdens het congres De Dynamiek van het Limburgs in december 2016 ben ik daarom begonnen met een lans te breken voor hen die het dialect spreken en/of verstaan, maar die niet als zodanig worden (h)erkend om verschillende redenen. Bovendien bepleitte deze lezing een inclusiever begrip van noties als 'Limburger' en 'Limburgs dialect'. 
In lijn met deze lezing zou ik graag de campagne Insluitende taal willen ontwikkelen die bewustzijn creëert onder inwoners van Limburg en daarbuiten, dat (streek)talen en dialecten niet per se gebonden zijn aan bepaalde sprekers. Op basis van mijn onderzoek, kan deze campagne mensen laten zien wat het met iemand doet wanneer deze persoon indirect wordt uitgesloten, bijvoorbeeld omdat in gesprek met een bepaald persoon automatisch overgeschakeld wordt naar een andere taal dan de taal die deze persoon misschien ook prima spreekt en/of verstaat. In de huidige Nederlandse samenleving waar steeds vaker geluiden opgaan dat inwoners zich niet thuis lijken te voelen, is het cruciaal om zulke campagnes in het leven te roepen zodat mensen zich ervan bewust worden dat dagelijkse praktijken en realiteiten meervoudiger zijn dan de initiële associaties die we allemaal hebben. Om het effect van de campagne te vergroten, zou er gebruik gemaakt moeten worden van aansprekende rolmodellen en woordvoerders die in staat zijn stereotype associaties tussen talen en sprekers uit te dagen en het brede scala aan dagelijkse talige realiteiten en variaties te illustreren.

\section{Trainingen voor professionals, leerlingen en studenten}

Voortbouwend op de bewustzijnscampagne Insluitende taal zouden er interactieve trainingen ontwikkeld moeten worden die deelnemers bewust kunnen maken van de taal-ideologische stereotypen en associaties die zij hebben. Rollenspellen zouden ingezet kunnen worden om deelnemers te laten ervaren welke in- en uitsluitende effecten taalpraktijken kunnen hebben op de gevoelens van erbij horen (belonging) en er niet bijhoren (unbelonging). Zo kunnen de trainingen handvatten bieden aan deelnemers om gesprekspartners in het vervolg open te benaderen en vaker gebruik te maken van luistertalen en meertalige gesprekken. Deze trainingen zouden met name geschikt zijn voor professionals in de maatschappelijke hulpverlening, ambtenaren en docenten in het lager en hoger onderwijs. Bovendien zouden dergelijke trainingen ook goed gebruikt kunnen worden in het basisonderwijs om een zelfbewuste en onbevangen nieuwe generatie groot te brengen.

\section{Kritische heroverweging van beleid}

De inzichten van Talking In and Out of Place zouden gezien moeten worden als een pleidooi voor zowel onderzoekers als beleidsmakers en politici om maatschappelijke problemen en uitdagingen niet enkel te verklaren langs etnische scheidslijnen of op basis van achtergronden van mensen. Met dit proefschrift heb ik beoogd te laten zien dat het belangrijk is, zo niet cruciaal, om oog te hebben voor de daadwerkelijke talige en culturele praktijken van mensen en de manieren waarop zij zich thuis voelen, of niet, in bepaalde plekken.

Daarmee moedigt dit proefschrift beleidsmakers aan om etnografisch verkregen inzichten in de maatschappij serieus te nemen en mee te nemen in de besluitvorming en beleidsprocessen. Alleen dan is het mogelijk beleid aan te laten sluiten op de daadwerkelijke behoeften en wensen die leven binnen de maatschappij. Uiteraard kost dit meer tijd en geld, maar dit zou gezien moeten worden als een investering in plaats van enkel een kostenpost. Etnografisch inzicht in de samenleving dient namelijk als een maatschappelijke thermometer voor sociale cohesie en maatschappelijk welzijn.

Bovendien hoopt dit proefschrift een verandering teweeg te kunnen brengen in het 
debat over taal en met name over dialect in termen van 'goed' of 'fout', bijvoorbeeld goede of foute spelling of uitspraak. Dit onderzoek heeft laten zien dat er geen 'goed' of 'fout' bestaat en dat het begrip van wat 'goed' of 'fout' is per situatie en gesprekspartner kan verschillen. De oordelen van 'goed' of 'fout' zijn daarmee arbitrair te noemen en het onderstreept wederom dat taal een beweeglijk en constant veranderend proces is dat zich aanpast aan de situatie en context waar mensen zich in begeven en elkaar ontmoeten.

In dit proefschrift is meermaals herhaald dat termen als 'allochtoon' en 'autochtoon' lege hulzen zijn die weinig toevoegen of inzicht bieden in de werkelijke talige en culturele praktijken van mensen. Ik pleit er dan ook sterk voor dat beleidsmakers en politici op zoek gaan naar inclusievere noties om duiding te geven aan onze maatschappij.

\section{Linguistic Landscaping voor ondernemers}

In sommige hoofdstukken van Talking In and Out of Place is gewerkt met het zogenaamde linguistic landscape paradigma (cf. Landry en Bourhis 1997). Dit paradigma onderzoekt welke talige middelen er vertoond worden in publieke ruimtes om zo te bestuderen hoe vitaal bepaalde 'talen' zijn in een gebied. In dit proefschrift heb ik een uitgebreider paradigma ter overweging gegeven dat, naast de focus op het tonen van geschreven taal in publieke ruimtes, ook aanmoedigt het gebruik van talige middelen in interacties te onderzoeken.

Linguistic Landscaping kan ingezet worden als een efficiënt instrument door ondernemers en winkeleigenaren om hun branding en marketingstrategieën in kaart te brengen en te optimaliseren. Linguistic Landscaping kan ondernemers helpen inzage te krijgen in de manier waarop zij taal het beste kunnen gebruiken om klandizie te trekken en/of te vergroten binnen een bepaalde gebied. Linguistic Landscaping is in staat informatie te verschaffen over 1) welke geschreven talige middelen het beste getoond kunnen worden in folders en winkels (bijvoorbeeld in etalages, schappen en op prijskaartjes) en 2) welke talige middelen het beste ingezet kunnen worden tijdens interacties met klanten.

\section{Mogelijke partners}

Verschillende partners kunnen benaderd worden voor een eerste oriëntatiegesprek waarin verdere samenwerking onderzocht dient te worden. Enkele potentiële interessante partners zijn: Huis voor de Kunsten Roermond, streektaalfunctionaris Ton van den Wijngaard (Limburg) en Jos Swanenberg (Noord-Brabant), verschillende lokale overheden in Limburg (bijvoorbeeld Gemeente Maastricht en Gemeente Roermond), ondernemersraden van winkelcentra (bijvoorbeeld Brusselsepoort Maastricht en Designer Outlet Center Roermond) en welzijnsinstellingen (bijvoorbeeld Wel.Kom Roermond/Venlo).

Heeft u vragen of wilt u graag verder praten over of samenwerken aan de valorisatiemogelijkheden van dit onderzoek, dan kunt u per e-mail contact opnemen: lottethissen@ hotmail.com. 


\section{About the author}

Lotte Thissen (Roermond, 1988) obtained her bachelor and master degree in Cultural Anthropology at Utrecht University. For her bachelor degree, she carried out fieldwork in Antigua (Guatemala) and later, for her master degree, in Volendam (the Netherlands). At VU Amsterdam, she obtained her master degree in Culture, Organization and Management (Cum Laude) based on her research on social cohesion and conflict trainings in Amsterdam-West. Lotte has worked as a tutor at Maastricht University (2011-2015), where she taught courses on language policies, academic writing, and European identity. She received her Basic Teaching Qualification (BKO) in 2014. Lotte has published peer-reviewed articles and chapters in edited volumes on language practices, identity and belonging politics, and center-periphery perceptions. In 2015, she was a Ph.D. fellow at the University of Copenhagen for three months within the research group Language and Place - Linguistic Variation in Urban and Rural Denmark. She presented her work at international conferences, made appearances in local media, and gave popular talks within the Limburg area. Lotte wrote Talking In and Out of Place at the Literature and Arts department of the Faculty of Arts and Social Sciences at Maastricht University (2011-2017). Currently, she is employed as a lecturer of Intercultural Communication at Zuyd University of Applied Sciences in Maastricht. 
